Helenice Nazaré da Cunha Silva

\title{
O IMPERADOR-DINOSSAURO NO REINO DAS PALAVRAS DE JOSÉ CARDOSO PIRES
}

Tese de Doutorado

Tese apresentada ao Programa de Pós-Graduação em Literatura, Cultura e Contemporaneidade do Departamento de Letras da PUC-Rio como parte dos requisitos parciais para obtenção do título de doutor em Letras.

Orientadora: Prof ${ }^{\mathrm{a}}$. Izabel Margato 


\section{Helenice Nazaré da Cunha Silva}

\section{O Imperador-dinossauro no reino das palavras de José Cardoso Pires}

Defesa de Tese apresentada como requisito parcial para obtenção do grau de Doutor pelo Programa de Pós-Graduação em Literatura, Cultura e Contemporaneidade do Departamento de Letras do Centro de Teologia e Ciências Humanas da PUCRio. Aprovada pela Comissão Examinadora abaixo assinada.

Profa. Izabel Margato Orientadora Departamento de Letras - PUC-Rio

Profa. Mariana Custódio do Nascimento Lago Departamento de Letras - PUC-Rio

Prof. Marcos Vinicius Fiuza Coutinho Departamento de Letras - PUC-Rio

Prof. Ronaldo Menegaz Academia Brasileira de Letras - ABL

Profa. Patricia Peterle Figueiredo Santurbano UFSC

Profa. Denise Berruezo Portinari Coordenadora Setorial do Centro de Teologia e Ciências Humanas - PUC-Rio 
Todos os direitos reservados. É proibida a reprodução total ou parcial do trabalho sem autorização da Universidade, da Autora e da Orientadora.

\section{Helenice Nazaré da Cunha Silva}

Licenciada em Letras pela Universidade Federal do Pará (1986), Especialista em Teoria Literária pela Universidade Federal do Pará (1996) e Mestre em Estudos Literários pela Pontifícia Universidade Católica do Rio de Janeiro (2007). Professora do Instituto Federal de Educação, Ciência e Tecnologia de São Paulo - Campus Cubatão desde 2011.

Ficha Catalográfica

Silva, Helenice Nazaré da Cunha

O imperador-dinossauro no reino das palavras de José Cardoso Pires / Helenice Nazaré da Cunha Silva ; orientadora: Izabel Margato. - 2013.

172 f. : il. (color.) ; $30 \mathrm{~cm}$

Tese (doutorado)-Pontifícia Universidade Católica do Rio de Janeiro, Departamento de Letras, 2013.

Inclui bibliografia

1. Letras - Teses. 2. Pires, José Cardoso. 3. Literatura portuguesa. 4. Fábula. 5. Censura. 6. Poder. I. Margato, Izabel. II. Pontifícia Universidade Católica do Rio de Janeiro. Departamento de Letras. III. Título.

CDD: 800 


\section{Agradecimentos}

Gostaria de agradecer neste espaço a todos os que acompanharam minha jornada, apoiando, dando opiniões, me encorajando a continuar, partilhando os momentos de cansaço e também os mais felizes.

Agradecimento especial:

À Professora Doutora Izabel Margato, minha orientadora, pela maneira como conduziu a orientação, incentivando-me, dando-me liberdade para desenvolver um ponto de vista próprio, mas, ao mesmo tempo, questionando-me e contribuindo com sua experiência para ampliar as discussões levantadas durante a pesquisa. E principalmente pelo apoio incondicional.

Agradecimentos calorosos:

Aos amigos e alunos do IFSP - Campus Cubatão, pela compreensão e pelo apoio incondicional.

À minha família, em especial meu marido Celso, minhas filhas Amanda e Marina, meus genros Danilo e Bruno, pelo apoio sem limites e pela convivência com minhas angústias e ausências.

Ao professor Alexandre Mountary, pela atenção.

A Maria Cristina, pela valiosa leitura e contribuição críticas na construção desta Tese.

Aos meus alunos, pela solidariedade e pela compreensão de minhas ausências.

À Banca Examinadora, pela presença relevante na etapa final desta trajetória.

À VRAC, pela contribuição para a realização deste trabalho.

Aos amigos do IFSP - Campus Cubatão, pela compreensão e pelo apoio incondicional.

À Secretaria da Pós-Graduação do Departamento de Letras da PUC-Rio, na pessoa de Francisca Ferreira de Oliveira (Chiquinha) e Daniele de Oliveira Cruz, pela presteza e simpatia com que desempenham seu ofício.

A todos os que me apoiaram neste percurso, agradeço afetuosamente. 


\section{Resumo}

Silva, Helenice Nazaré da Cunha; Margato, Izabel. O ImperadorDinossauro no reino das palavras de José Cardoso Pires. Rio de Janeiro, 2013. 172p. Teses de Doutorado - Departamento de Letras, Pontifícia Universidade Católica do Rio de Janeiro.

Esta tese se propõe a analisar a fábula Dinossauro Excelentíssimo, de José Cardoso Pires, procurando identificar os procedimentos com os quais o autor representa as relações entre a censura e o poder da palavra e, consequentemente, a dimensão política que se configura a partir dessa relação. Pretende-se observar, na obra citada, as estratégias utilizadas pelo autor para criar a história de um personagem ditador, o Imperador da Torre das Sete Chaves, que manipula as palavras com a finalidade de espalhar o medo no Reino dos Mexilhões. Isso possibilitou ao escritor interrogar as memórias do cotidiano da ditadura salazarista e incorporar, na ficção, fatos históricos que marcaram a história político-social da sociedade portuguesa. Desse modo, investiga-se o diálogo existente entre história e ficção, com a intenção de demonstrar como o ditador censura a palavra do outro para construir o discurso opaco do poder. Por fim, verifica-se o modo como é delineada a imagem do poder, inteligível através da metamorfose do Imperador em Dinossauro.

\section{Palavras-chave}

José Cardoso Pires; Literatura Portuguesa; Fábula; Censura; Poder. 


\section{Resumé}

Silva, Helenice Nazaré da Cunha; Margato, Izabel (Directeur). L'empereur dinosaure dans le royaume de la parole de José Cardoso Pires. Rio de Janeiro, 2013. 172p. Thése de Doctorat - Departamento de Letras, Pontifícia Universidade Católica do Rio de Janeiro.

Cette thèse vise à analyser la fable Dinossauro Excelentíssimo, de José Cardoso Pires, pour y identifier les procédures avec lesquelles l'auteur interrogue les relations entre la censure et la puissance de la parole et donc la dimension politique qui est configuré de cette relation. L'intention c'est d'observer, dans l'ouvrage cité, les stratégies utilisées par l'auteur pour créer l'histoire d'un caractère, personnage, dictateur, l'empereur de la Tour des Sept Clés, qui gère des mots avec le but de la peur au tour du Reino dos Mexilhões, dans le ce qui a permis à l'auteur de s'interroger sur les souvenirs de la dictature de Salazar au jour le jour et à intégrer, dans la fiction, les faits historiques qui ont marqué l'histoire politique et sociale de la société portugaise. Ainsi, nous étudions le dialogue entre histoire et fiction, avec le but de démontrer comment le dictateur censeure-t-il la parole de l'autre pour construire le discours opaque du pouvoir. Enfin, il y a la façon dont elle est présentée l'image du pouvoir, intelligible par la métamorphose de l'empereur dans le Dinossauro.

\section{Mots-cles}

José Cardoso Pires; littérature portugaise; Fable; Censure; Puissance. 


\section{Abstract}

Silva, Helenice Nazaré da Cunha; Margato, Izabel (Advisor). The Dinosaur Emperor in the realm of the word of José Cardoso Pires. Rio de Janeiro, 2013. 172p. Doctoral Thesis - Departmento de Letras, Pontifícia Universidade Católica do Rio de Janeiro.

The overall aim of this thesis is to analyze the fable Dinossauro Excelentíssimo, by José Cardoso Pires, identifying the procedures with which the author questions the relationships between censorship and the power of the word and, therefore, the political dimension that takes shape having this relationship as basis. This dissertation investigates, in the work cited, the strategies used by the author to create the story of a dictator character, the Emperor of the Tower of Seven Keys, who manipulates words with the purpose of spreading fear in the Kingdom of Mussels (a Kingdom), which enabled the writer to question the memories of everyday life in the Salazar dictatorship and incorporate, in fiction, historical facts that marked the political and social history of Portuguese society. Thus, the dialogue that exists between history and fiction in investigated with the intention of demonstrating how the dictator censors people's words to build the opaque discourse of power. Finally, it is verified the way in which the image of power is outlined, understandable through the metamorphosis of the Emperor into a Dinosaur.

\section{Keywords}

José Cardoso Pires; Portuguese Literature; Fable; Censorship; Power. 


\section{Sumário}

1 INTRODUÇÃ

2 JOSÉ CARDOSO PIRES, UM FABULADOR …......................... 20

2.1 Linhas do destino, cruzadas e partidas .......................................... 20

2.2 As linguagens de José Cardoso Pires ................................................. 27

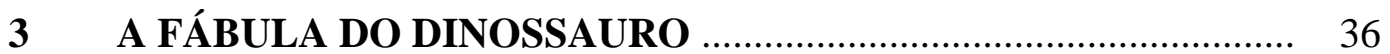

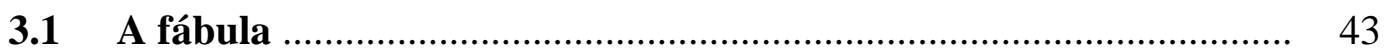

3.1.1 A retórica ............................................................................... 50

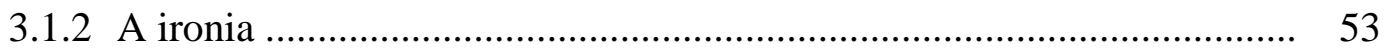

3.2 Os fios que tecem a fábula ........................................................ 57

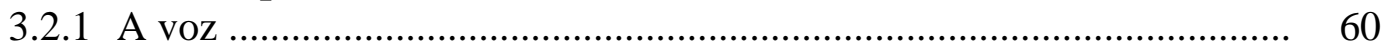

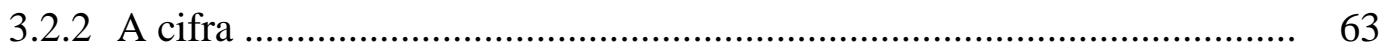

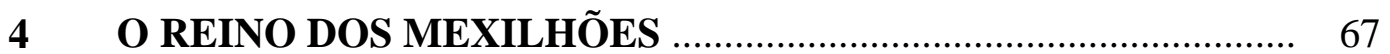

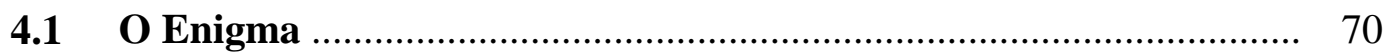

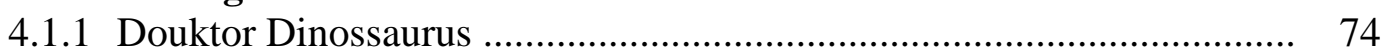

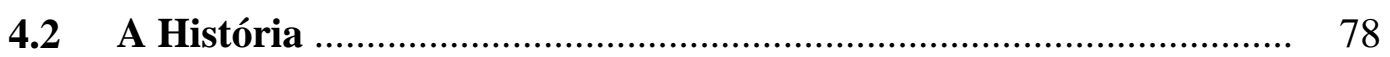

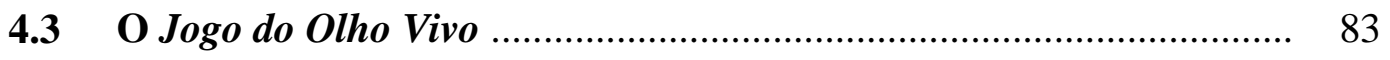

5 A IMAGEM FRAGMENTADA DO PODER ….......................... 93

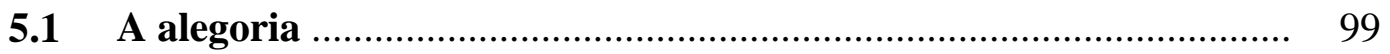

5.2 A configuração do poder .............................................................. 108

5.2.1 O poder do Dinossauro ................................................................... 112

6 O INTELECTUAL: “UM ANIMAL INCÓMODO” ................... 116

6.1 A censura ou a câmara de torturar palavras .................................. 123

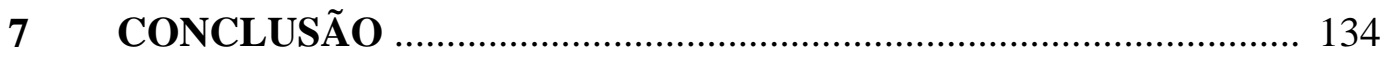

REFERÊNCIAS BIBLIOGRÁFICAS ....................................... 137

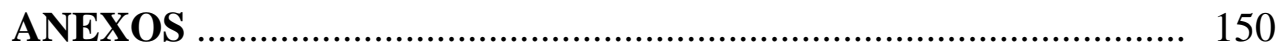

Anexo 1 - José Cardoso Pires: A censura fez-nos viver num país

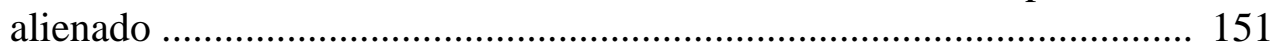

Anexo 2 - Figuras ................................................................. 162 


\section{Lista de Figuras}

Fig. 1 - Fuga da família do Imperador-Dinossauro e perseguição dos jumentos - Ilustração de João Abel Manta

Fig. 2 - Imagem do homem-pássaro de Max Ernst 163

Fig. 3 - As idades de Salazar 1 - Caricatura de João Abel Manta 164

Fig. 4 - As idades de Salazar 2 - Caricatura de João Abel Manta 165

Fig. 5 - As idades de Salazar 3 - Caricatura de João Abel Manta 166

Fig. 6 - Personagens Dê-Erres, assessores e doutores - Ilustração de João Abel Manta

Fig. 7 - O Imperador-Dinossauro discursando para o povo - Ilustração de João Abel Manta

Fig. 8 - Detalhe da imagem do Imperador-Dinossauro após sofrer a metamorfose. Ilustração de João Abel Manta

Fig. 9 - Capa de Dinossauro Excelentíssimo, primeira edição - Ilustração de João Abel Manta

Fig. 10 - Confronto na Assembleia Nacional, Miller Guerra versus Cazal Ribeiro - Caricatura de Baltazar 171

Fig. 11 - Representação da censura - Ilustração de João Abel Manta 
Lançaram o mistério e propositadamente deixaram ficar à vista a chave que o desmascara e que vai servir para novo mistério.

José Cardoso Pires 


\section{INTRODUÇÃO}

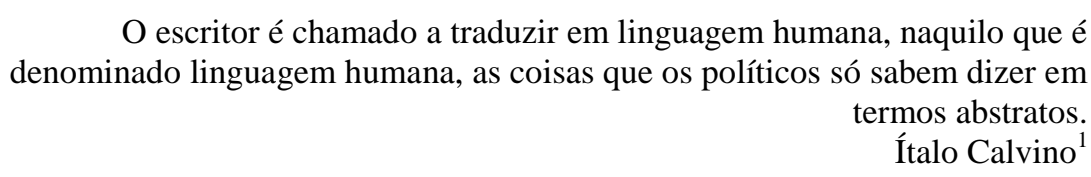

Trilhar as veredas de um texto literário constitui um ato de exploração através de um caminho em busca incessante de revelações. No reino das palavras, há fragmentos de vários sistemas que arquitetam um todo, semelhante a um mosaico de ideias dispostas estrategicamente a fim de refletirem a multiplicidade da palavra. É a partir dessa arquitetura que o leitor se arrisca a interpretar o texto, procurando conhecer os arranjos com o quais o autor tão astutamente organizou a sua narrativa. Dessa forma, o leitor é levado a "jogar com os signos em vez de destruí-los, em colocá-los numa maquinaria de linguagem cujos breques e travas de segurança arrebentaram, em suma, em instituir no próprio seio da linguagem servil uma verdadeira heteronímia das coisas" ${ }^{2}$.

De acordo com essa perspectiva, elegemos como objeto de análise a fábula Dinossauro Excelentíssimo ${ }^{3}$, do escritor português José Cardoso Pires, publicada em 1972, a fim de investigar as estratégias através das quais esse autor representa as relações entre a censura e o poder da palavra e, consequentemente, a dimensão política que se configura a partir dessa relação. Pretendemos observar, na obra citada, os procedimentos utilizados pelo autor para criar a história de um personagem ditador, o Imperador da Torre das Sete Chaves, que manipula as palavras com a finalidade de espalhar o medo no Reino dos Mexilhões - o que possibilitou ao escritor interrogar as memórias do cotidiano da ditadura salazarista e incorporar, na ficção, fatos reais que marcaram a história político-social da sociedade portuguesa.

\footnotetext{
${ }^{1}$ CALVINO, Ítalo. Notas sobre a linguagem política. In: ___. Assunto encerrado: discurso sobre literatura e sociedade. Trad. Roberta Barni. São Paulo: Companhia da Letras, 2006, p. 366.

${ }^{2}$ BARTHES, Roland. Aula. Trad. e posfácio Leyla Perrone-Moisés. São Paulo: Cultrix, 2002, p. 28-29.

${ }^{3}$ Segundo o autor, essa fábula foi escrita em Londres, em 1969, e dada como presente de Natal às filhas Rita e Ana. Embora diga que a fábula esteja ligada ao fato de que a "estória se passa no tempo em que os animais falavam e os homens sufocavam", sabemos que Cardoso Pires pretendia contar duas histórias, isto é, ao narrar a estória de um dinossauro, denunciava, concomitantemente, como testemunha, o regime totalitário do Estado Novo português.
} 
A retomada da análise dessa obra de José Cardoso Pires se dá em razão de não se ter esgotado o eixo temático desenvolvido em minha Dissertação de Mestrado, A rede de palavras e a máscara de Imperador em Dinossauro Excelentíssimo ${ }^{4}$. Nesse sentido, visamos o aprofundamento da leitura e análise do texto literário referido, procurando examinar com maior acuidade o diálogo existente entre história e ficção, com o propósito de demonstrar como o ditador censura a palavra do outro para produzir o discurso opaco do poder. Buscamos identificar ainda a maneira como é criada a imagem alegórica do poder, percebida principalmente pela justaposição de fragmentos que revelam gradativamente a metamorfose do Imperador em Dinossauro.

Meu interesse pela obra de José Cardoso Pires foi despertado durante o Curso de Mestrado, a partir da leitura e da análise de algumas de suas obras, selecionando-as, até definir a escolha de Dinossauro Excelentíssimo como obra a ser focalizada em minha Dissertação. Essa motivação está diretamente relacionada ao engenho com o qual esse autor tece seus enredos, pois suas complexas narrativas tendem a subverter as regras dos gêneros com o objetivo de simultaneamente construir e desconstruir sentidos e de levantar temáticas desafiadoras, que caracterizam tanto a sua obra fictícia quanto a ensaística. Além disso, há questões de cunho político presentes na obra que mereciam ser mais bem exploradas. Dizer "não" ao silenciamento, em qualquer que seja a forma de manifestação (artística ou não), torna-se um ato de rememoração, por não permitir que se esqueça aquilo que foi vivenciado. Nisso, parece haver uma volta ao passado, e, para que não se cometam os mesmos erros, não se pode silenciar os traumas e as arbitrariedades ocorridas durante o Estado Novo em Portugal. Afirma Cardoso Pires que, mesmo que haja desmemória

[...] e mentira a lavrar por entre nós e forças interessadas em desdizer a terrível experiência do passado transformando-a numa calúnia ou em algo já obscuro e improvável. É por isso, e só por isso, que retomei o Dinossauro Excelentíssimo e o registro como uma descrição incómoda de qualquer coisa que oxalá se nos vá tornando cada vez mais fabular e delirante. ${ }^{5}$

\footnotetext{
${ }^{4}$ CUNHA, Helenice. A rede de palavras e a máscara de Imperador em Dinossauro Excelentíssimo. Dissertação de Mestrado. Rio de Janeiro: Pontifícia Universidade Católica do Rio de Janeiro, Departamento de Letras, 2007.

${ }^{5}$ PIRES, José Cardoso. Post-scriptum. In: 119. O burro em pé. Alfragide: Leya, 2010, p. 118-
} 
Esse fabular que pretende negar o silêncio recuperando a memória foi também um dos motivos que me levaram a retomar a fábula Dinossauro Excelentíssimo nesta Tese de Doutorado. Além do caráter de pronunciamento desse texto literário, buscamos aprofundar algumas questões relacionadas às estratégias utilizadas por Cardoso Pires que surgiram durante as análises do corpus selecionado no Curso de Mestrado, mas, por motivos de ordem acadêmica, foram deslocadas para uma análise posterior e somente ao longo desta Tese são retomadas e aprofundadas. Neste sentido, em decorrência das novas leituras realizadas, as reflexões acerca dos temas abordados nessa obra foram-se tornando mais claras e, à medida que ampliamos nossa leitura, certos procedimentos de escrita do autor passaram a ser delineados de modo mais efetivo. Isso nos possibilitou a retomada de Dinossauro Excelentíssimo, para destacá-la dentre as demais e sobre ela nos debruçarmos com o objetivo de tornar nossa análise mais eficiente e completa, contudo, ainda sem o propósito de esgotar o tema.

Desse modo, o prosseguimento desta pesquisa se deu principalmente em razão do caráter alegórico relativo às concepções de ditadura e de ditador que dela emergem, do modo como o autor reescreve o gênero fábula, e, sobretudo, das reflexões que faz acerca dos mecanismos que organizam o poder e da atuação do escritor como intérprete de questões culturais, políticas e sociais. Nessa fábula, o papel da escrita, a arquitetura textual e a elaboração intelectual são evidenciados em cena a fim de examinarem uma questão sob duas óticas distintas, mas coexistentes. A primeira, de ordem literária, diz respeito à forma como a narrativa é tecida, pela inserção da escrita como razão formal que se entrelaça à trama, pondo em discussão, por esse procedimento, a intertextualidade de vários textos. A segunda, de ordem política, relaciona-se ao tema de que trata a fábula objeto deste estudo. É através dessa investigação que conseguimos "ver" as questões suscitadas; dentre elas, destacam-se a imagem do poder e da censura e o papel do intelectual. Portanto, entendemos que ambas as perspectivas se assentam sobre o “jogo do literário” enquanto face ambígua de significação, interpretação e experiência sociocultural.

Para a realização de tal tarefa, esta Tese se propõe a investigar, na obra em questão, as estratégias empregadas por Cardoso Pires para criar a história de um personagem, um ditador, que manipula a "realidade", cuja imagem passa por 
constantes mudanças até configurar-se como um Dinossauro, que mantém em movimento uma rede de poder, pois, segundo Foucault, o poder

Funciona como uma rede de dispositivos ou mecanismos a que nada ou ninguém escapa, a que não existe exterior possível, limite ou fronteiras. Daí a importante e polêmica idéia de que o poder não é algo que se detém como uma coisa, como uma propriedade, que se possui ou não. Não existe de um lado os que têm o poder e de outro aqueles que se encontram alijados. Rigorosamente falando, o poder não existe; existem sim práticas ou relações de poder. ${ }^{6}$

Em Dinossauro Excelentíssimo, Cardoso Pires demonstra desvelar "certos mecanismos de funcionamento do político, certas relações de poder" disserta sobre o poder da palavra, da literatura, da voz de um narrador que se pronuncia para criticar e até mesmo contestar a versão da História propagada pelo ditador Salazar. Nesse contexto, seguimos a perspectiva de Izabel Margato, que, além de reconhecer o engenho de José Cardoso Pires, considera também a Literatura "como um pronunciamento, um ato de intervenção e interpelação face à realidade social e política" ${ }^{\Perp}$ produzida pelo escritor-intelectual.

Portanto, o tema objeto de análise torna-se relevante porque busca examinar os procedimentos de escrita de José Cardoso Pires, o qual revitaliza o gênero fábula e destaca o poder da palavra e o exercício da censura, realizando um dos propósitos da Literatura, que é o de interrogar, ainda que a censura estabeleça "a conveniente confusão de valores, necessárias a humilhar os escritores insubmissos

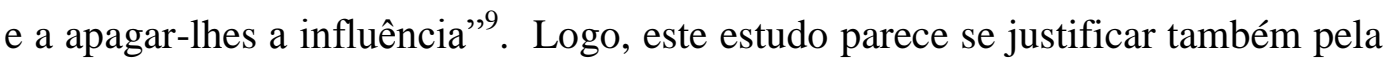
possibilidade de enxergarmos a época da ditadura salazarista pelo viés de outro olhar, através de uma leitura que se debruça sobre o cotidiano marginalizado pela História oficial, revelando-nos outras versões por entre as fendas da História.

As análises desenvolvidas neste estudo foram realizadas conforme um suporte teórico que, de certa forma, nos ajudou a responder às questões levantadas. Por isso, tomamos como eixo norteador os textos teóricos de autores

\footnotetext{
${ }^{6}$ FOUCAULT, Michel. Microfísica do poder. Trad. Roberto Machado. São Paulo: Graal, 2004, p. XIV.

${ }^{7}$ PIGLIA, Ricardo. Ler errado é muito produtivo. Entrevista concedida a Julián Fuks. Revista Entrelivros. São Paulo: Duetto, ano 2, n. 21, jan. 2007, p. 17.

${ }^{8}$ MARGATO, Izabel. O intelectual em tempos difíceis. In: ; GOMES, Renato Cordeiro (Orgs.). O papel do intelectual hoje. Belo Horizonte: Ed. UFGM, 2004. p. 154.

${ }^{9}$ PIRES, José Cardoso. Técnica do golpe de censura. In: ___ . E agora, José? Lisboa: Moraes, 1977, p. 188.
} 
como Edward Said, Izabel Margato, José Cardoso Pires, Michael Foucault, Roland Barthes, Ricardo Piglia, Walter Benjamin, entre outros, cujas obras apoiaram a análise da fábula objeto de estudo. Durante nossa pesquisa, examinamos também livros que abordam o contexto histórico específico em que a narrativa de José Cardoso Pires é inserida e produzida. Além disso, são utilizados, como textos de apoio à elaboração da Tese, ensaios críticos e livros que analisam a fábula Dinossauro Excelentíssimo.

Seguindo-se à presente Introdução, considerada o Capítulo 1, esta Tese se encontra estruturada em cinco capítulos, organizados de modo a articular as leituras e análises de textos teóricos à fábula referida, e um capítulo de Conclusões.

Cabe ao Capítulo 2, "José Cardoso Pires, um fabulador", uma breve apresentação da vida e obra de Cardoso Pires, incluindo uma introdução à leitura da obra Dinossauro Excelentíssimo. Nele, relatamos o percurso do autor José Cardoso Pires enquanto jornalista, escritor e crítico literário. Através de vasta pesquisa, mostramos as influências que marcaram sua identidade como escritor literário, assim como a postura de se colocar contra o próprio sistema em que viveu, apesar do Estado opressor e da austera censura da polícia política do governo sob o regime de Salazar (PIDE). Além disso, evidenciamos os princípios estéticos que marcam a construção do sistema literário de Cardoso Pires, como recursos que ele utiliza para a criação de suas obras literárias, e sua importância no panorama da literatura do século XX em Portugal. Assim, nesse percurso do autor no interior do contexto literário português, passamos a reconhecer as transformações políticas e sociais que transparecem nas expectativas, avanços, recuos e ilusões de uma sociedade e do próprio autor.

No Capítulo 3, "A fábula do Dinossauro", buscamos, através de análise e do levantamento histórico do valor da fábula na Literatura, a compreensão dos parâmetros que conduziram o autor à reescrita desse gênero. Nesse sentido, o gênero fábula é examinado como estratégia narrativa utilizada para "dizer sem revelar", isto é, como texto exemplar carregado de intenções políticas, cuja arquitetura estética está assentada na ironia. Conforme demonstram nossas análises, Cardoso Pires toma algumas características da fábula clássica para transfigurá-la numa fábula em que encontramos, como personagens principais, 
dois animais que se debatem, cujos históricos são milenares, representados em um espaço obscuro, assim como o ambiente do Reino na fábula: mexilhão versus dinossauro - são esses os habitantes da fábula do Dinossauro.

Por sua vez, o Capítulo 4, “O Reino dos Mexilhões”, é dedicado ao diálogo entre a fábula e o contexto histórico-cultural. E os recursos que Cardoso Pires utiliza para trazer à tona as relações entre ficção e história apresentam alguns eixos, que estão relacionados à intertextualidade. Nesse capítulo, observamos que o autor cria três linhas para tecer a imagem do Reino: numa primeira vista, verificamos a imediata relação entre a biografia de Salazar e a do personagem protagonista Imperador-Dinossauro; numa segunda perspectiva, percebemos a intertextualidade entre o protagonista e um "personagem" que representa dentro da História Cultural Ocidental um exemplo máximo da religiosidade, Jesus Cristo; numa terceira, visualizamos a configuração de um reino que nos remete ao Estado Novo português. Ocorre que, na narrativa de Cardoso Pires, a palavra se converte em signo polivalente, isto é, aos significados preexistentes se entrelaçam novos sentidos. É por meio desse jogo que percebemos, em relação à palavra e à estrutura fabular, o resgate das memórias do cotidiano da ditadura salazarista, indo além dos fatos registrados pelo discurso historiográfico, assunto que o referido autor revela em Dinossauro Excelentíssimo. Portanto, entendemos que Cardoso Pires busca relatá-lo de acordo com uma nova perspectiva, tornando-o ficção, para reescrever a história de um ditador - na fábula, o Imperador do Reino dos Mexilhões.

Já a partir do Capítulo 5, "A imagem fragmentada do poder", procuramos entender e analisar a composição da imagem do poder e da censura, considerando que essas ideias são abstratas. Partindo desse princípio, inferimos que a imagem do poder e de sua rede semântica se delineia através da metamorfose do Imperador e da alegoria do poder, conforme demonstrado pelo exame da capa de Dinossauro Excelentíssimo, ilustrada por João Abel Manta, ilustrador também da primeira edição dessa obra. Além disso, desenvolvemos um estudo sobre o poder da palavra, analisando as dissertações que o narrador faz sobre o poder e sobre a censura da palavra, com a intenção de demonstrar os mecanismos e os meios com os quais são tecidos, propagados e destruídos os discursos do poder. Partimos, portanto, do pressuposto de que a presença de um complô político não é casual, 
pois é perceptível, na fábula, a configuração de uma rede de poder político cuja finalidade é mantê-la como um círculo permanente e fechado a sete chaves. Ao mesmo tempo, buscamos compreender como esse sistema político manipula e constrói a imagem de um ditador, um Imperador que se metamorfoseia em Dinossauro. Encontramos, em diferentes momentos da narrativa, descrições plásticas cuja visibilidade é intensificada pelos fragmentos significativos, que vão se construindo paulatinamente numa alusão a uma imagem pictórica, ou detalhada numa gravura; as figuras híbridas e silenciosas, assim concebidas, dissertam sobre questões sociopolíticas. Considerando essa ótica, pesquisamos Dinossauro Excelentíssimo, ilustrada por João Abel Manta, com a intenção de investigar como Cardoso Pires busca, em geral, justapor diversas "imagens" em seu texto, elaboradas a partir de escritos recortados para compor alegoricamente a ideia de poder, ou de opressão, que perpassa silenciosa por entre as palavras no Reino dos Mexilhões.

No Capítulo 6, "O intelectual: um animal incómodo", buscamos analisar o contexto em que a fábula foi publicada, durante a ditadura portuguesa de Salazar, época em que a censura, sob as ordens de órgãos competentes, retirava de circulação qualquer discurso que pudesse "perturbar a segurança pública”. Houve, nesse período, um conjunto de condições que propiciaram aos escritores portugueses o exercício de uma escrita ambivalente, construída nas entrelinhas como "metáforas apropriadas"10. Por isso, tomamos o tema insubmissão ${ }^{11}$ como eixo norteador de nossa pesquisa, investigando de que maneira o escritorintelectual fez de sua "fala" um pronunciamento literário contestador. Examinamos também a imagem metafórica do olho do poder, exemplificado através da câmara de torturar palavras, criada pelo Imperador-Dinossauro.

Em síntese, todas essas questões são analisadas no decorrer desta Tese, durante o exercício de leitura e de escrita, além de outros olhares convergentes para o assunto central: a censura, as relações de poder, o poder da palavra e sua dimensão política. Em meio às questões propostas, os temas história, poder,

${ }^{10}$ RODRIGUES, Graça Almeida. Breve história da censura literária em Portugal. 1. ed. Lisboa: Bertrand, 1980, p. 75-76. Biblioteca Breve, V. 54.

${ }^{11}$ A concepção de resistência se justifica porque acreditamos que um dos papéis do intelectual é, conforme Foucault, o de "destruidor de evidências e das universalidades" (FOUCAULT, Michel. Microfísica do poder, cit., p. 242), portanto, acreditamos que José Cardoso Pires desempenha essa função na cultura portuguesa. A resistência tem essa função de estilhaçar as verdades "universais", que são saberes cristalizados. 
censura, depuração linguística e atuação do intelectual são privilegiados, pesquisados em textos teóricos e literários e, por fim, desenvolvidos, a fim de revelarem um novo olhar sobre a fábula de José Cardoso Pires e sobre a teia discursiva da cultura portuguesa num período marcado pelo sequestro da palavra do outro. 


\section{JOSÉ CARDOSO PIRES, UM FABULADOR}

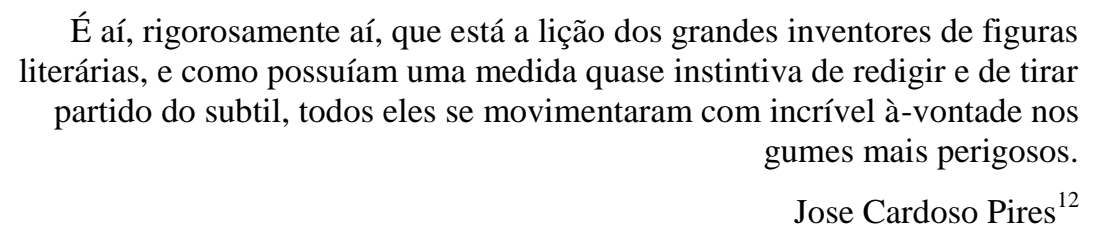

Em "Uma Pequena Grande História”, prefácio de $O$ Anjo Ancorado, de José Cardoso Pires, Mario Dionísio relata que Cardoso Pires o procurou, com o manuscrito nas mãos, para pedir-lhe conselhos sobre o ofício de escrever. Dionísio o aconselhou a considerar o contexto histórico em que viviam, uma vez que aquele era o momento para a ação política. Algum tempo depois, Dionísio percebeu que a atuação daquele escritor foi além do que ele esperava do estreante; para ele, o autor:

Sem prejuízo da sua cota-parte de participação e risco na acção política legal e ilegal, sem a qual nenhum escritor antifascista, que tivesse escolhido a barricada que ele escolhera, podia ter a experiência humana indispensável - sua matéria prima - e a consciência tranquila. ${ }^{13}$

Afirma Dionísio que, como outros autores que viveram o Estado Novo português, Cardoso Pires lutou, sobretudo escrevendo. Em constante aprendizado, passou longas horas e longos anos aprimorando sua escrita, "buscando, ousando, arriscando, melhorando sempre, até se tornar no grande escritor hoje admirado aquém e além-fronteira" ${ }^{\prime 14}$.

\subsection{Linhas do destino, cruzadas e partidas}

José Cardoso Pires exerceu diversas atividades ao longo de sua existência: foi aprendiz de marinheiro, tradutor, jornalista, editor, escritor, entre outros

\footnotetext{
${ }^{12}$ PIRES, José Cardoso. Visita à oficina: o texto e o pré-texto I: memória descritiva. In: E agora, José? Lisboa: Dom Quixote, 1999, p. 118.

${ }^{13}$ DIONÍSIO, Mário. Uma pequena grande história. In: PIRES, José Cardoso. $O$ anjo ancorado. Lisboa: O Jornal, 1984, p. 7.

${ }^{14}$ Loc. cit.
} 
ofícios. Iniciou sua carreira nas Letras escrevendo para a revista Eva, em 1949, e, em seguida, foi designado diretor da revista Almanaque ${ }^{15}$. Porém, em 1958, a censura salazarista o proibiu de publicar um semanário, fruto de um estágio realizado pelo autor na revista Época, de Milão. Pires dirigiu também o Diário de Lisboa durante o período pós-25 de Abril, função que se configurou como uma experiência conturbada e traumatizante, porque ele passava o tempo a "apagar os fogos cruzados das facções políticas da redação" ${ }^{16}$. Ao regressar a Portugal, em 1961, voltou a dirigir a revista Almanaque e tornou-se, nessa mesma época, membro da direção da Sociedade Portuguesa de Escritores, presidida por Jaime Cortesão. Como assistente de Victor Silva Tavares, Cardoso Pires dirigiu o Suplemento Literário do Diário de Lisboa e, depois, o suplemento A Mosca, do mesmo jornal. Em 1980, publicou a reportagem “Apocalipse 2", sobre o Vietnam, para as revistas Triunfo, de Madrid, e Hoy, do México - esta, parcialmente publicada no Diário de Lisboa.

José Cardoso Pires foi um dos mais notáveis ${ }^{17}$ escritores portugueses do século XX; seu talento foi reconhecido imediatamente pela crítica - fato que despertou, desde cedo, a vigilância da censura. Logo a ditadura portuguesa (19281974) lançava um olhar censório sobre Cardoso Pires, e sobre todos aqueles que dela discordavam. Por isso, é possível compreender como a trajetória de Pires ficou marcada simultaneamente pelo questionamento e pela inquietação desse leitor e escritor atento às questões sociais, políticas e culturais do país. Trata-se de um escritor que circulou facilmente entre os meios sociais, relacionando-se sempre com intelectuais e artistas diversos. Segundo Maria de Lurdes Sampaio, ainda durante a adolescência, Cardoso Pires caminhou por entre os espaços marginais dos bairros lisboetas; para o próprio escritor, foram várias as experiências que o levaram a uma recusa "à integração conceituada":

$\mathrm{Na}$ faculdade, [...], as minhas relações com os colegas eram poucas. Em vez da Associação e dos cafés de estudantes, frequentava os bilhares da Almirante Reis,

\footnotetext{
${ }^{15}$ Segundo o próprio Cardoso Pires, era "uma revista de vanguarda, [...], o programa era simples: ridicularizar os cosmopolitismos como sinónimos de provincianismo, sacudir os bonzos e demonstrar que a austeridade é uma capa do medo e da ausência de imaginação. Todavia, este programa não foi posto em prática logo de início, porque a revista [...] teve uma primeira fase bastante convencional" (PORTELA, Arthur. Cardoso Pires por Cardoso Pires. Lisboa: Dom Quixote, 1991, p. 43).

${ }^{16}$ PORTELA, Arthur. Cardoso Pires por Cardoso Pires, cit., p. 48.

17 José Cardoso Pires recebeu a maior distinção oferecida a um escritor: foi galardoado com a Ordem da Liberdade e com a Grande Cruz de Mérito Cultural.
} 
patrulhava os bailes dos Bombeiros, da Rádio Graça ou das Manas Pretas e não me dava mal. Nessa mesma altura, ao mesmo tempo cumpria a minha recruta literária à mesa do Café Herminius, fazia serões de jogo numa ou outra casa clandestina [...]. Tudo somado, era uma população medíocre que me servia de contraponto à Universidade e à literatura. ${ }^{18}$

E foi nesses lugares que ele aprendeu variedades linguísticas como "calão, gíria e outros sociolectos oralizantes de que a tessitura polifónica da sua prosa (também) é feita"19.

Em determinado episódio da vida do autor, pode ser evidenciado o seu caráter afeito a aventuras, ou sua propensão a correr riscos. Em 1945, Cardoso Pires se alistou na Marinha Mercante, da qual foi expulso após um ano por indisciplina. Nesse período conheceu o território africano e pôde ver de perto alguns métodos desumanos da colonização portuguesa. Em entrevista concedida a Artur Portela, Cardoso Pires fala sobre sua viagem à África: "[fui] a bordo do cargueiro 'Sofala' que carregava tropas para Timor. Em Lourenço Marques desertei e vim, preso para Lisboa. Foi o final da guerra." ${ }^{20}$ Conta-nos ainda como presenciou o que chamou de "demonstração da moral colonialista." ${ }^{21} \mathrm{O}$ autor relata que o que mais o repugnou foi "a defloração de garotas negras por marinheiros de passagens" 22 e as "filas de presos a asfaltarem o pavimento da avenida, ligados por correntes uns aos outros, como escravos". 23

De acordo com Sampaio, existem muitos indícios dessa experiência na obra do autor - especialmente a constatação das barbáries ocorridas durante o colonialismo na África -, como assinala a estudiosa através de um ensaio de José Cardoso Pires, datado de 1951, dedicado ao escritor Faulkner. Nele, o autor português faz "reflexões irónicas acerca do silêncio do português continental sobre questões rácicas, seguidas de uma alusão à sua fugaz visão do apartheid sulafricano" 24 . Ressalta ainda Sampaio que as viagens de Cardoso Pires por mar o impulsionaram a escrita de Viagem à Ilha de Satanás (1997), uma espécie de

\footnotetext{
${ }^{18}$ PORTELA, Arthur. Cardoso Pires por Cardoso Pires, cit., p. 25.

${ }^{19}$ SAMPAIO, Maria de Lurdes Morgado. José Cardoso Pires das Neves. In: Base Ulyssei@s: escritores e outros criadores em deslocação. Porto: Instituto de Literatura Comparada Margarida Losa. Disponível em: <http//:www.ilcml.com>. Acesso em: 3 ago. 2013.

${ }^{20}$ PORTELA, Arthur. Cardoso Pires por Cardoso Pires, cit., p. 27.

${ }^{21}$ Loc. cit.

${ }^{22}$ Loc. cit.

${ }^{23}$ Loc. cit.

${ }^{24}$ SAMPAIO, Maria de Lurdes Morgado. Escritores e outros criadores em deslocação, cit.
} 
sátira à maneira de ficção científica, relacionada com as ambições expansionistas dos portugueses em tempo de acirradas guerras coloniais ${ }^{25}$.

Em meio a esse mar de experiências vividas, Cardoso Pires parece vagar pelas ruas de Lisboa, lendo e decifrando pistas - sobretudo, vivências do cotidiano político-social português, ocultadas pela censura portuguesa. Desse modo, o autor realiza o seu processo de criação através de diversos gêneros: romances, contos, crônicas, memórias, ensaios e dramas. Como destaca a crítica, de modo geral, Cardoso Pires leu e escreveu, através de uma focalização cinematográfica, a sociedade portuguesa do Estado Novo: rural, marialva, colonialista, censurada, vigiada, imobilizada pelo medo, mas sempre questionada pelo autor, o qual, em sua ficção, é capaz de expor a lenta metamorfose sofrida por essa sociedade, como é exemplarmente representada em $O$ Delfim (1968). Sobre a construção dessa obra, o crítico Liberto Cruz afirma que o romance é:

[...] obra maior da literatura portuguesa do nosso século, e sem dúvida, a obraprima do autor, o fundo e a forma entendem-se e fundem-se com uma austeridade notável. A metáfora e a alegoria, o concreto e o imediato, o subtil e o comezinho são focados com a mesma intensidade. Simultaneamente enigmático e franco, obscuro e aberto, o romancista intercepta com sagacidade a atmosfera que sustém e provoca o mundo dos desocupados. Cada vez menos interessado em contar histórias, faz da ambiência uma figura cimeira do próprio romance. ${ }^{26}$

Em outra obra de José Cardoso Pires, Caminheiros e outros contos (1949), já se percebe, conforme diz Petar Petrov, um realismo "próprio", que vai se desenvolver e se firmar em História de amor (1952), O Hóspede de Job (1953) e $O$ Anjo ancorado $(1958)^{27}$. Na já citada entrevista concedida a Artur Portela, Cardoso Pires que ressalta a origem de toda a sua compreensão e percepção do mundo, se encontra na influência dos mestres Tchekov, Poe, Hemingway, Melville, entre outros:

[...] minha determinação de escrever se deve sobretudo aos contistas. Tchekov e Poe, acima de quaisquer outros. Do Poe reli tudo, inclusivamente a Gênese dum Poema que eu sempre considerei genialmente elucidativa e transparente como uma anatomia, digamos assim, da arte de escrever. [...] Por causa da depuração e do tratamento coloquial do texto de Hemingway é que eu me vim a interessar por

25 Segundo a ensaísta, Cardoso Pires foi um dos primeiros a dissertar sobre os dramas da descolonização e da identidade portuguesa no pós-Revolução (Ibid.).

${ }^{26}$ CRUZ, Liberto. Análise crítica e seleção de textos. 1. ed. Lisboa: Arcádia, 1972, p. 31.

${ }^{27}$ PETROV, Petar. O realismo na ficção de José Cardoso Pires e de Rubem Fonseca. Lisboa: Difel, 2000. 
Stephen Crane e por Damon Runyon, para não falar já do grande Melville de nosso deslumbramento. $^{28}$

No período que compreende os anos de 1969 a 1971, José Cardoso Pires foi professor de Literaturas Brasileira e Portuguesa no King's College da Universidade de Londres. Ali, como escritor, manteve contato com Rui Knopfli, Gabriel García Márquez e Mário Vargas Llosa ${ }^{29}$. Ao retornar de Londres a Portugal, o autor publicou a fábula Dinossauro Excelentíssimo (1972) e o ensaio "Técnica do Golpe de Censura", simultaneamente editado em Londres, na revista Index, e em Paris, na revista Esprit; contudo, a versão original só pôde ser encontrada em Portugal depois da Revolução de 25 de Abril, ao ser incluída pelo autor em seu livro de ensaios E agora José? (1977). Segundo Petar Petrov, nesse ensaio, Cardoso Pires denuncia como a prática e os mecanismos da censura foram utilizados durante o regime salazarista. Esclarece ainda de que modo, perpetuado durante séculos, por diversas gerações, o discurso do poder da censura perdurava, porque havia ainda "milhares de quilômetros de textos lançados às fogueiras e aos arquivos" ${ }^{\prime 30}$. Portanto, os textos ensaísticos de Cardoso Pires estão relacionados diretamente a experiências artísticas do autor. Em geral, tratam de "reflexões que comportam dimensões metaliterárias, quando questionam problemáticas de ordem sócio-cultural e ideológica em estreita conexão com aspectos estéticos" ${ }^{\text {31 }}$. Logo após a Revolução dos Cravos, Cardoso Pires explicitou a Arthur Portela:

A censura, além de hipocrisia do Poder, era uma máquina de corrupção e de terrorismo cultural em ligação directa com a Administração e com a polícia política. Foi para denunciar a práxis e os mecanismos que a definiam que eu escrevi a Técnica do Golpe de Censura. ${ }^{32}$

Nesse contexto, percebe-se que Dinossauro Excelentíssimo veio apresentar novas estratégias de escrita, desenvolvidas nas coletâneas de contos $O$ burro-empé (1979) e A República dos corvos (1988), esta última é composta por de sete narrativas, entre elas uma nova edição de Dinossauro Excelentíssimo. Nessas

\footnotetext{
${ }^{28}$ PORTELA, Arthur. Cardoso Pires por Cardoso Pires, cit., p. 31.

${ }^{29}$ SAMPAIO, Maria de Lurdes Morgado. Escritores e outros criadores em deslocação, cit.

${ }^{30}$ PIRES, José Cardoso. Visita à oficina o texto e o pré-texto, cit., p. 163.

31 PETROV, Petar. O ensaio na obra de José Cardoso Pires. GridHoster.com. Apoio Instituto Camões / Fundação para a Ciência e a Tecnologia. Disponível em: <http://www.geocities.com/ail_br/oensaionaobradejosecardoso.htm>. Acesso em: 7 out. 2012.

${ }^{32}$ PORTELA, Arthur. Cardoso Pires por Cardoso Pires, cit., p. 38.
} 
obras, entram em cena o realismo mágico, o fantástico, o conto exemplar e o fabulário ao avesso, e nelas o autor valoriza procedimentos de criação como a ironia e a sátira.

Após a queda da ditadura, em 1974, Cardoso Pires se propôs analisar o obscuro mundo da polícia política e a rede psicológica ligada ao corpo do terror. Nesse sentido, no mesmo ano, ele escreveu o drama Corpo-delito na sala de espelhos, encenado somente seis anos depois de sua criação. A respeito desse texto, o autor relata: "Concebi-o à partida como um espetáculo da tortura e à medida que fui escrevendo descobri várias associações entre a encenação teatral e a encenação dos interrogatórios policiais. ${ }^{, 33}$ No ano seguinte, o autor publicou o ensaio Sete parágrafos sobre a liberdade (1975).

O mesmo processo criativo, que se estrutura como encenação de um interrogatório policial, se repete no romance Balada da Praia dos Cães (1982). Nos anos 80, embora houvesse uma tendência para a escrita de romance histórico, Cardoso Pires priorizou a história recente, narrada no romance, através de uma estrutura policial, cuja finalidade é revelar os mistérios da sociedade salazarista. Seguindo essa mesma propensão, a de analisar a sociedade portuguesa a partir da "pequena história", lançou Alexandra Alpha (1987), que, segundo o crítico João Décio,

[...] se constituiu em intrigante e instigante "puzzle" que reúne ficção, poesia, música, cinema, história, política e Portugal. [...]. Nele encontramos a organização da linguagem cinematográfica, associadas ao levantamento e discussão de problemas sociais, morais e económicos de Portugal nos últimos vinte anos. ${ }^{34}$

Em Alexandra Alpha, os personagens cardosianos vivenciam um jogo político, cujos princípios e cujas consequências estão entrelaçados à ideia de poder, autoridade e liberdade. A rede entrevista na ordem política repousa fundamentalmente em dois princípios contrários: a autoridade e a liberdade. O primeiro, iniciador, é a fé que obedece; o segundo, determinante, tem por consequência a liberdade de pensamento. São esses dois princípios que formam um par cujos termos estão ligados um ao outro: a autoridade supõe necessariamente uma liberdade que a reconheça ou a negue; já a liberdade, no

\footnotetext{
${ }^{33}$ PORTELA, Arthur. Cardoso Pires por Cardoso Pires, cit., p. 66.

${ }^{34}$ DÉCIO, João. Uma nova faceta da ficção de José Cardoso Pires. Jornal Letras e Letras. Lisboa, n. 45, 17 abr. 1991, p. 14.
} 
sentido político do termo, pressupõe do mesmo modo uma autoridade que lide com ela, a reprima ou a tolere.

A partir de então, José Cardoso Pires publicou também Poker Aberto (19861987), série de cinco crônicas no semanário O Jornal; como dito anteriormente, A República dos corvos (1988); A cavalo no Diabo (1994), coletânea de crônicas semanais para o jornal O Público; De profundis, valsa lenta (1997). De toda a sua escrita, este último se distancia dos procedimentos discursivos empregados nas obras anteriores, como afirma Cardoso Pires:

Não considero que seja um livro terminal. Digamos que De Profundis, Valsa Lenta será, quando muito, na minha opinião, um espaço branco no meio da minha escrita, da minha obra. Eu nunca pensei em escrever este relato, ou esta memória, não sei como posso chamar a este texto. ${ }^{35}$

Segundo António Guerreiro, para escrever De profundis, valsa lenta, Cardoso Pires precisou se munir da proteção da surdez "contra o canto da sereia da literatura. A difícil missão deste livro é narrar um acontecimento bio-gráfico até ao limite, bastante estrito, em que ele é narrável sem se entrar no território da ficção." 36

Nesse mesmo ano, Cardoso Pires publicou Lisboa. Livro de bordo: vozes, olhares, memorações ${ }^{37}$, em que apresenta essa cidade como protagonista da narrativa, pois nesse espaço foram reunidas impressões e histórias criadas em passeios e incursões pela cidade. Ao analisar a obra cardosiana, Francisco Belard conclui que o autor

[...] leva-nos a passear, ou a passar por onde lhe apetece, privilegiando os lugares de que gosta (sem deixar de dar bicadas a alguns aspectos que o aborrecem na cidade dos corvos). Uma Lisboa ondulante e diversa, embora a vamos reconhecendo ao sabor do gosto divagante, mas ordenado, com que o escritor a dá a conhecer. [...]. Mantendo o belo conjunto de imagens que o convertem não em 'coffee-table book' mas num livro-objecto no melhor sentido do termo, ou seja, o de um objecto que nos sujeita. ${ }^{38}$

\footnotetext{
${ }^{35}$ PIRES, José Cardoso. Entrevista ao Diário de Notícias. Lisboa, 11 jun. 1997, p. 14.

${ }^{36}$ GUERREIRO, António. A morte branca. Jornal Expresso. Lisboa, 24 maio 1997. Disponível em: <http://www.citi.pt/cultura/literatura/romance/cardoso_pires/lisboa_bo rdo.html>. Acesso em: 20 set. 2012.

${ }^{37}$ BELARD, Francisco. Fados vadios. Jornal Expresso. Lisboa, 8 nov. 1997. Disponível em: <http://www.citi.pt/cultura/literatura/romance/cardoso_pires/lisboa_bordo.html >. Acesso em: 20 set. 2012.

${ }^{38}$ Loc. cit.
} 
Em seu imaginário, Cardoso Pires teceu os cenários de suas narrativas construindo um retrato poético de Lisboa, o que leva Óscar Lopes a considerar tal livro como uma história de amor: "de amor por uma cidade, de que só se fala por dentro, sem um panorama, com subtítulos sempre inesperados e sempre oportunos",39.

Conforme exposto, acreditamos que todo esse percurso de Cardoso Pires pôde afirmá-lo como uma presença arguta no universo da Literatura Portuguesa Contemporânea. Em pleno processo ditatorial, ele cultivou corajosamente a independência e a liberdade de dizer "não" a qualquer aparelho ditador, ainda que, certas vezes, tenha sido cerceado pela vigilância cerrada em torno de seus escritos.

A fim de corroborar a apresentação de José Cardoso Pires realizada neste estudo, recorremos às palavras de Guilherme d'Oliveira Martins sobre o autor: “ $O$ homem, o escritor, o colecionador de episódios da vida das pessoas e da cidade foi, antes de tudo, alguém que gostava de despertar consciências." ${ }^{40}$ Encontramos também relevante comentário do escritor António Lobo Antunes acerca da obra de José Cardoso Pires: "Quase todos os seus livros são fábulas. Fábulas sobre o poder."41

\subsection{As linguagens de José Cardoso Pires}

Sim, contar é um jogo e, francamente, se eu gosto de jogos! O que eles me tentam! Fiz um, até. Jogo do Olho Vivo, chamava-se ele. ${ }^{42}$

Uma das principais características da ficção de Cardoso Pires é o "persistente enraizamento na realidade histórica e quotidiana",43, de forma que

39 LOPES, Óscar. Depoimento. Público. Lisboa, 27 out. 1998. Disponível em: http://alfarrabio.di.uminho.pt/vercial/zips/nsimoes01.rtf. Acesso em 20 set. 2013.

${ }^{40}$ MARTINS, Guilherme d'Oliveira. José Cardoso Pires: pedagogo da vida. Jornal de Letras. 27 nov. 2002. Disponível em: <http://www.citi.pt/cultura/literatura/romance/cardoso_pires/>. Acesso em: 10 set. 2012.

${ }^{41}$ ALVES, Clara Ferreira (Dir.). José Cardoso Pires. Documentário. Prod. e realiz. Rosa Filmes. Lisboa: RTP, 1998. Disponível em: <http://www.citi.pt/cultura/literatura/romance/cardoso _pires/>. Acesso em: 10 set. 2010.

42 PIRES, José Cardoso. Disperso 1. Lisboa: Dom Quixote, 2005, p. 277.

${ }^{43}$ LOURENÇO, António Apolinário. A arte de ser português. Jornal de Letras, Artes e Ideias. n. 285, 21 dez., p. 22. 
cada narrativa é capaz de revelar "um novo pretexto para aprofundar a sua reflexão sobre a existência, a vida política ou a própria arte de ser português"44.

Os escritos cardosianos - em especial a fábula Dinossauro excelentíssimo - questionam, através da reflexão, vários temas sobre a condição humana. Isso é perceptível no diálogo entre um "contador de estória" e sua filha, indo do estético ao político, com destaque para o poder da palavra. $\mathrm{O}$ autor, sem vincular-se a uma corrente estético-literária, imprimiu em sua obra preocupações sociais e políticas, pois seus textos teóricos e ficcionais criticam de modo incisivo os valores propagados pelo regime salazarista.

Umberto Eco discorre em ensaio $^{45}$ sobre a semelhança entre a sistematização elaborada por Aristóteles em Poética e as descrições que fazem alguns autores ao analisarem a própria obra, acabando por demonstrarem o modus operandi de construção de suas narrativas. Para desenvolver sua hipótese, Eco analisa particularmente as descrições feitas por Edgar Allan Poe sobre a análise que fez sobre a composição de $O$ corvo. O ensaísta demonstra que Poe, em suas análises, revela a estrutura subjacente à criação do poema em análise, a elaboração consciente, a investigação detalhadamente criada, as "normas" eficazes, todas essas etapas ligadas à exegese do poema $O$ corvo. Comprova-se a hipótese de Eco de que alguns autores possuem uma poética própria, ligada de certa forma às ideias expostas na poética aristotélica. Cardoso Pires considera que Poe fez "uma anatomia, digamos assim, da arte de escrever" ${ }^{\prime 6}$. Portanto, entendemos que, por analogia, poderíamos delinear uma poética, a "poética cardosiana", em que observamos traços da poética aristotélica ${ }^{47}$, principalmente no que concerne não apenas à definição do objeto de seu discurso, mas também à explicação a respeito dos mecanismos empregados para a sua produção. Assim, compreendemos as motivações estabelecidas no fazer criativo de Cardoso Pires, entre a "organização de uma forma" e a "estória que ele tem para transmitir" 48 .

\footnotetext{
${ }^{44}$ LOURENÇO, António Apolinário. A arte de ser português, cit., p. 22.

${ }^{45}$ ECO, Umberto. A poética e nós. In: ___ . Sobre a literatura. Rio de Janeiro: Record, 2003, p. 219-234.

${ }^{46}$ PORTELA, Arthur. Cardoso Pires por Cardoso Pires, cit., p. 31.

${ }^{47}$ Segundo Umberto Eco, "Lubomir Doležel colocou a questão de saber se a poética aristotélica é uma obra de crítica (que visa à avaliação das obras de que fala) ou de Poética, que, justamente, visa a definir as condições da literariedade" (ECO, Umberto. A poética e nós, cit., p. 222-223).

${ }^{48}$ PIRES, José Cardoso. Visita à oficina: o texto e o pré-texto I, cit., p. 120.
} 
Do mesmo modo, Cardoso Pires, também no ensaio Visita à oficina: o texto e o pré-texto $I^{49}{ }^{49}$, decompõe os elementos narrativos que construíram o relato do romance $O$ Delfim e discorre sobre o momento do ato criativo: "Então, [...], fechado o último parágrafo e com as convenientes independências sobre o acto de criar, é possível ao autor repensar e descobrir muitas das linhas e dos impulsos que trabalharam a lógica interna do seu conto.” 50

Ele distingue, assim, as variáveis com as quais construiu o romance referido. No entanto, essas reflexões que incluem a "lógica interna" não se limitam a esse romance, porque nele há, entrelaçados à análise do autor, "conceitos" que delineiam traços para a constituição de uma poética cardosiana. Esta se projeta através de uma escrita questionadora e interrogativa que

[...] desgasta, afia e vai até o osso dos fatos, para trazer à luz os movimentos do pensamento que fazem de sua escrita uma espécie de 'prova', ou de 'pedra de toque' a partir da qual são aferidas as interpretações consagradas pelo uso ou pelas políticas de consenso. ${ }^{51}$

Segundo Izabel Margato, tal recurso já pode ser notado nos

[...] pequenos contos inaugurais, o narrador já não assume o confortável lugar daquele que conta uma história linear e detalhada, mas o lugar inquieto e inquietante daquele que, ao contar, interroga, perscruta e analisa. Nesse processo cambiante, o leitor, gradativamente, fica enleado e seduzido pelo clima de mistério que, logo de saída, é instalado pela estratégia da escrita interrogativa. A partir daí somos conduzidos por desvasão, contruções alusivas, fugidias, em que se percebe, claramente, que o mais importante não pode estar visível, ou melhor, que na estratégia de escrita de Cardoso Pires o importante nunca se conta. ${ }^{52}$

Tomemos por oportuno um conceito de Roland Barthes, para quem a "literatura não é um corpo ou uma sequência de obras, [...], mas o grafo complexo das pegadas de uma prática: a prática de escrever." 53 É dessa prática de escrita interrogativa que se constitui o complexo projeto literário de José Cardoso Pires, em que o autor se considera um "aprendiz em vez de escritor" ${ }^{\text {, }}$, um homem que

\footnotetext{
${ }^{49}$ PIRES, José Cardoso. Visita à oficina: o texto e o pré-texto I, cit.

${ }^{50}$ Ibid., p. 121 (grifos nossos).

${ }^{51}$ MARGATO, Izabel. Os procedimentos de escrita de José Cardoso Pires. Revista Via Atlântica. São Paulo: Faculdade de Filosofia, Letras e Ciências Humanas da USP, n. 9, p. 196, jun. 2012.

52 MARGATO. Izabel. Os procedimentos de escrita de José Cardoso Pires, cit., p. 203.

${ }^{53}$ BARTHES, Roland. Aula, cit., p. 16-17.

${ }^{54}$ NASCIMENTO, Manuel do. Encontro com Cardoso Pires. O Primeiro de Janeiro. Lisboa, 28 set. 1958 , p. 58 .
} 
"ama sobretudo experimentar a realidade e, logo, experimentar a expressão que convém a essa realidade em movimento." ${ }^{, 55}$.

Considerando o fato de que a escrita mantém uma estreita relação com a leitura - lê-se para escrever - , entendemos que, para Cardoso Pires, essa relação passa por outras linguagens, como, por exemplo, a pintura, a qual se torna um estimulo talvez maior do que a literatura, provocando-lhe uma incitação à rebeldia, um desejo concreto de "transgredir a matéria e a ordem formal da escrita" ${ }^{, 56}$. Nesse sentido, não podemos nos esquecer de que, conforme aponta Barthes, toda "imagem é de certo modo uma narrativa" ${ }^{\$ 7}$. Isso talvez explique a maneira fragmentada das narrativas cardosianas, partindo do princípio de que o leitor vai, aos poucos, seguindo pistas que precisam ser decifradas, num processo que consiste em

[...] jogar com os signos em vez de destruí-los, em colocá-los numa maquinaria de linguagem cujos breques e travas de segurança arrebentaram, em suma, em instituir no próprio seio da linguagem servil uma verdadeira heteronímia das coisas. ${ }^{58}$

Esse jogo com os signos ao qual se refere Barthes se estende para a estrutura fabular de Cardoso Pires, pois ele narra como se nunca fosse apresentar explicitamente a ideia, na busca de um objeto que

[...] nunca será explicitamente nomeado. Para proceder a essa modalidade de escrita, o escritor trabalha com duas lógicas narrativas diferentes: uma que investiga e analisa de forma cerrada o objeto ou o fato em questão e uma outra que, através da elipse e da condensação, vai pontuando um sentido subterrâneo - como um subtexto - que nunca se deixa ver completamente. ${ }^{59}$

Portanto, a organização geométrica desenvolvida por Cardoso Pires em suas narrativas revela-se nas várias camadas significativas da "estória narrada". Essa sobreposição de planos só é possível porque o texto apresenta em sua estrutura um "significado" que se desdobra em um "significante", para que desse processo se possa reescrever, em seguida, uma estória que vai completar aquela subjacente à outra, oculta. Nesse sentido, Izabel Margato esclarece: a "camada de sentido

\footnotetext{
${ }^{55}$ NASCIMENTO, Manuel do. Encontro com Cardoso Pires, cit., p. 58.

${ }^{56}$ PORTELA, Arthur. Cardoso Pires por Cardoso Pires, cit., p. 69.

${ }^{57}$ BARTHES, Roland. Aula, cit., p. 39.

${ }^{58}$ Ibid., p. 28-29.

${ }^{59}$ MARGATO. Izabel. Os procedimentos de escrita de José Cardoso Pires, cit., p. 197.
} 
oculto não anula ou enfraquece a versão visível, antes a contém ou precisa dela para uma outra possibilidade de sentido" 60 .

As estratégias com as quais o autor arquiteta seus textos se apresentam como enigmas, como iscas provocadoras, que atuam de forma semelhante aos índices da História para o historiador. Assim, percebemos que, ao mesmo tempo em que o narrador nos conta a estória do Dinossauro Excelentíssimo, nós construímos a nossa estória (fábula). É um jogo de (des)vendar que se aplica não só ao autor, que interpreta os "fatos", mas também ao leitor, que os recria sobre determinado ângulo. Pensando na função do leitor, Cardoso Pires busca a teoria de Marcel Duchamp, segundo a qual é o leitor quem "estabelece contato da obra com o mundo exterior, decifrando-a nas suas qualificações mais profundas" ${ }^{\text {"61 }}$. Para Duchamp, o mobile é um objeto que apresenta o movimento intrínseco de seus elementos acionado por um motor, de modo que, a cada nova composição há possibilidades de outro tipo de movimento, autônomo, proporcionado pelas pequenas formas que o artista cuidadosamente cria, recortando chapas metálicas e dispondo-as calculadamente nas pontas de suas hastes interligadas. Suspenso no espaço, o agente gerador do movimento é agora a corrente de ar ou o sopro do espectador. Nesse sentido, continua Cardoso Pires: "lembrar [...] as composições articuladas [...] os mobili de Dieter Rot; onde 'o encontro' objeto/observador é provocatoriamente alterado por variações contínuas de enquadramento." ${ }^{, 62}$

Partindo dessa análise, entendemos que Cardoso Pires considera que toda ficção se baseia na dicotomia criação - leitura, procedimento utilizado ora pelo autor, ora pelo leitor, de modo que esse processo criativo se desdobra em várias leituras e "jamais se considera encerrado"63, porque há sempre um novo leitor, uma nova criação subentendida. Cardoso Pires relaciona o conceito de leitor ao estilo do escritor, explicando que "as ousadias, a profundidade de sínteses, o ritmo, a organização do tempo narrativo"64 são consequências dessa cumplicidade, que se relaciona consequentemente à cumplicidade entre escritor e leitor ideal.

\footnotetext{
${ }^{60}$ MARGATO, Izabel. Narrar para viver, seduzir e desencantar. Seminário "A situação da narrativa no início do século XXI: saudades de Sherazade?" Semear. Rio de Janeiro: Cátedra Padre Antonio Vieira de Estudos Portugueses da PUC-Rio, n. 7, p. 265-275, 2002.

${ }^{61}$ PIRES, José Cardoso. Visita à oficina: o texto e o pré-texto I, cit., p. 119.

${ }^{62}$ Loc. cit.

${ }^{63}$ Loc. cit.

${ }^{64}$ Loc. cit.
} 
Do mesmo modo ${ }^{65}$ como Cardoso Pires discorre sobre a função e o desempenho do leitor, também o faz a respeito de seu processo criativo. Para ele, a criação "poética", embora não seja racionalizada, envolve "muitas intuições, certas imagens, iluminações de pormenores ou registros ao nível do inconsciente" ${ }^{\text {66 }}$, que só não despontam de forma caótica porque a própria história seleciona "a cor da voz com que a escreve, sua métrica, suas relações vocabulares" ${ }^{, 67}$. Enfim, a narrativa promove uma organização formal, pois, ao ser montada, revela "a coerência das contradições e das particularidades significantes" ${ }^{68}$.

Essas estratégias utilizadas pelo autor se articulam a outros procedimentos descritos por Mário Dionísio em "Uma pequena grande história”, prefácio da sétima edição do romance $O$ anjo ancorado. Segundo o crítico,

[...] é na montagem dos capítulos, como se diria das sequências dum filme, mais na ordenação narrativa do que no narrado ou descrito, que o Autor prepara a criação da surpresa que mais conta. Com técnica que vai buscar, tanto à linguagem do cinema [...] como à dos contadores de histórias da tradição popular. ${ }^{69}$

Mario Dionísio parece imaginar o momento de criação de Cardoso Pires, que elabora seus textos a partir de várias fontes. É como se ele as dispusesse sobre a mesa para agir como um jogador de baralho, alterando e encaixando suas cartas de vários modos até descobrir "a organização em que o rei, a dama e o valete mais realce ou mais se dissimule conforme as leis da surpresa exijam"70. O teórico percebe ainda que, a partir de determinado momento, é possível encontrar, com certa frequência, a citação de obras ou de autores antigos, mas esclarece que alguns "são reais outros são inventados",71 e têm a função "inequívoca de explicar o próprio texto ou a de encapotá-los aos olhos da censura" ${ }^{92}$.

De acordo com Cardoso Pires, a pintura é, dentre outros discursos, uma fonte desafiadora para "apanhar ideias", pois é a partir das imagens que compõem

${ }^{65}$ Cf. CUNHA, Helenice. A rede de palavras e a máscara de Imperador em Dinossauro Excelentíssimo, cit., p. 19.

${ }^{66}$ PIRES, José Cardoso. Visita à oficina: o texto e o pré-texto I, cit., p. 121.

67 Loc. cit.

${ }^{68}$ Loc. cit

${ }^{69}$ DIONÍSIO, Mário. Uma pequena grande história, cit., p. 30.

${ }^{70}$ Ibid., p. 24.

${ }^{71}$ Ibid., p. 33

${ }^{72}$ Loc. cit. 
um quadro que se cria nova imagem; é através de imagens condensadas que Pires demonstra as entrelinhas de alguns fatos, como, por exemplo, no romance $O$ anjo ancorado, em que o personagem escultor-crocodilo é convidado a admirar "um grande e maravilhoso quadro" ${ }^{, 73}$ :

Caça, álcool, cavalos, cachimbos, isso e umas certas gravuras representando, suponhamos, Dafne e Cloe, são ornamentos muito a jeito para exaltar o lado macho burguês. Vendo bem, aquela tapeçaria tinha mesmo 'mais do que isso'. Mostravanos uma cena de floresta em que os criados a pé eram da altura dos galgos, enquanto que os Senhores apareciam à escala dos símbolos da natureza criada por Deus, os carvalhos majestosos, céus e distâncias. ${ }^{74}$

O personagem, após contemplar o quadro, conclui: "Se na Idade Média se conhecesse a Perspectiva, metade deste sabor tinha ido por água abaixo." ${ }^{75}$ Há, no entanto, na narrativa, outro personagem (um viajante) que analisa o quadro e responde: "Pois, sim. Nessa altura ainda não se tinha descoberto a Perspectiva mas já havia uma perspectiva de classe. E está aí bem clara para quem quiser entender. Abre os olhos, mano crocodilo., ${ }^{, 76}$

Desse diálogo entre personagens, podemos perceber que há várias perspectivas de se "ler" essa tapeçaria, mas resulta da percepção (ou recepção) da tela a ideia sobre a "perspectiva de classe", dissertada no quadro à medida em que se organizam os traços fragmentados que o compõem. E essa ideia, assim interpretada, liga-se intrinsecamente à fábula do romance.

Na esteira de Mário Dionísio, o crítico Eduardo Prado Coelho afirma que, na narrativa cardosiana, existe uma rede textual formada a partir de lendas, boatos, mitos, anedotas, que servem como histórias exemplares, cuja função é apresentar alguma lição. "Digamos, para saltar algumas etapas do raciocínio, que o modo de contar é aqui um modo de decifrar, o que significa que tudo tende a aparecer cifra de outra coisa." ${ }^{, 77}$ Desse procedimento, infere-se que as representações de fatos metaforizados são como cifras para nós, leitores, a exemplo de quando o narrador faz uso de elementos extratextuais para trazer à tona temas submersos nas histórias narradas. Por isso,

\footnotetext{
${ }^{73}$ DIONÍSIO, Mário. Uma pequena grande história, cit., p. 81.

${ }^{74}$ Loc. cit.

${ }^{75}$ DIONÍSIO, Mário. Uma pequena grande história, cit., p. 81.

${ }^{76}$ Ibid., p. 81-82.

${ }^{77}$ COELHO, Eduardo Prado. O círculo dos círculos. In: PIRES, José Cardoso. O Delfim. Lisboa: Dom Quixote, 1999, p. 15.
} 
[...] não é certamente por acaso que a caça nos surge como o horizonte permanente das narrativas de Cardoso Pires. [...] funciona como denominador simbólico, incluindo o escritor para quem escrever é ir no encalço de uma presa, ou o leitor, que vai sempre em busca do sentido inacessível. [...] todo o universo literário de Cardoso Pires é dominado pela ideia de jogo. Escrever é entrar no jogo, fingindo saber que é apenas um modo elegante e obstinado de lidar com o que se não sabe. ${ }^{78}$

Eduardo Prado Coelho, em prefácio ao romance $O$ Delfim, analisa os procedimentos pelos quais Cardoso Pires construiu seu romance. Partindo de suas ideias, podemos considerar algumas características por ele observadas a fim de examinar outras obras cardosianas, como Dinossauro Excelentíssimo. De acordo com o ensaísta, podemos salientar que, na obra de ficção do citado autor, “contam-se os fatos, é certo, mas conta-se, sobretudo, o modo como os fatos são contados, e a paisagem histórica que resulta do entretecer desses modos"79.

De acordo com a linha de raciocínio aqui desenvolvida, é possível resgatar alguns conceitos que caracterizam o modus operandi da construção narrativa de

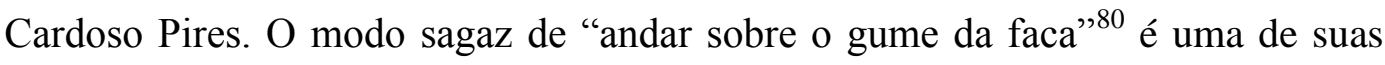
estratégias e aparece frequentemente em sua obra, como observamos na reflexão constante que o texto faz sobre sua própria composição, como explica o narrador: "Cartas do destino, partidas e dadas, e que mudam de trunfo conforme quem as sabe baralhar" ${ }^{\prime \prime}$; ou na intromissão do narrador, que parece meditar no exato momento da instância narrativa; ou na interlocução que o narrador tenta manter com o leitor para que participe também dessa reflexão: "Mas lê o resto, que já vais ver onde quero chegar." ${ }^{82}$ Conforme o narrador de Dinossauro Excelentíssimo, "a páginas tantas havia um comércio sombrio entre o Reino (ou Torre) do Ermitão e o Reino a Sério, o real. Começava mesmo a perguntar-se onde começava um e onde acabava o outro." ${ }^{83}$ A presença dessas alusões, somada aos ensaios críticos sobre a própria obra e sobre a de outros autores portugueses, cria um parâmetro que, em hipótese, se concretiza numa poética cardosiana.

Claro está que a ficção cardosiana tem um compromisso político, mas este não faz da sua obra um documento histórico; ao contrário, é necessário

\footnotetext{
${ }^{78}$ COELHO, Eduardo Prado. O círculo dos círculos, cit., p. 24.

${ }^{79}$ Ibid., p. 13.

${ }^{80}$ PIRES, José Cardoso. Visita à oficina: o texto e o pré-texto, cit., p. 118.

${ }^{81}$ PIRES, José Cardoso. Dinossauro Excelentíssimo, cit., p. 21.

${ }^{82}$ Ibid., p. 130.

${ }^{83}$ Ibid., p. 142-143.
} 
“compreender que a memória das coisas, dos seres e dos cheiros é um inestimável selecionador" ${ }^{\circ 4}$, porque, se houvesse ligação direta com os documentos históricos, a estória perderia sua característica fictícia. Conforme o autor, "a larga documentação, o amontoado de expressões, de imagens ou de achados [...] constrangem a narração, aliciando-a." ${ }^{, 55}$ Logo, a ficção perderia aquele caráter sobre o qual nos fala Barthes: "a literatura não diz que sabe alguma coisa, mas que sabe de alguma coisa; ou melhor: que ela sabe algo das coisas [...] porque ela encena a linguagem, em vez de, simplesmente, utilizá-la."

${ }^{84}$ PIRES, José Cardoso. Visita à oficina: o texto e o pré-texto I, cit., p. 125.

${ }^{85}$ Loc. cit.

${ }^{86}$ BARTHES, Roland. Aula. São Paulo: Cultrix, 2002, p. 19. 


\title{
3 A FÁBULA DO DINOSSAURO
}

\begin{abstract}
Contou mais o contador, falando de certo Reino onde nos velhos outroras vivia um imperador astuto, diabo e ladrão - imperador esse que, à força de matar palavras no falar de cada um, finou os seus ricos dias em paralisia da mentira, de sorte que não se sabe se afinal ele era homem, se era estátua ou apenas descrição. ${ }^{87}$ José Cardoso Pires
\end{abstract}

Publicada simultaneamente em Portugal e no Brasil em 1972, a fábula Dinossauro Excelentíssimo, que narra a vida de um imperador e de sua corte, está incluída, com outras duas obras de José Cardoso Pires: no volume de contos Burro em pé, de 1979 (nessa edição, a fábula foi revisada pelo autor após 25 de abril); e na coletânea de contos A república dos corvos (1988). Além disso, consta sua publicação em várias edições autônomas. Segundo Sampaio, “cumpria-se assim, pela mão do próprio autor, o acto de preservação da memória de transmissão de histórias de geração em geração" ${ }^{\text {88 }}$. O mesmo afirma o narrador ao final da história: "vieram gerações, morreram gerações - e em todas os pais lembravam aos filhos as estátuas que vigiavam o Reino." ${ }^{89}$ A narrativa descreve o "retrato grotesco de Salazar"90 (Dinossauro) e de seu governo ditatorial em Portugal (o Reino). Relata ainda o clima de opressão social e individual provocado pela censura ao povo português (os mexilhões), metaforizada na "câmara de torturar palavras". Subjacente a essa primeira visão está a relação aviltante estabelecida entre o homem e o poder absoluto.

Dinossauro Excelentíssimo conta a história de uma criança, escolhida por pessoas influentes (o padre, o regedor e a madrinha) da aldeia em que morava para ir estudar em Coimbra. Houve certas discordâncias entre "os personagens" quanto à profissão que o menino deveria seguir, o padre, contrariando os demais, decidiu o destino do menino: ele iria estudar as leis.

\footnotetext{
${ }^{87}$ PIRES, José Cardoso. A República dos Corvos. Lisboa: Dom Quixote, 1989, p. 51.

${ }^{88}$ SAMPAIO, Maria de Lurdes Morgado. As margens no centro: lugares de desatenção na obra de José Cardoso Pires. In: MORUJÃO, Isabel; SANTOS, Zulmira C. (Coords.). Literatura culta e popular em Portugal e no Brasil: homenagem a Arnaldo Saraiva. Porto: Cia das Artes, 2011, p. 246-258.

${ }^{89}$ PIRES, José Cardoso. Dinossauro Excelentíssimo, cit., p. 147.

${ }^{90}$ PIRES, José Cardoso in PORTELA, Arthur. Cardoso Pires por Cardoso Pires, cit., p. 36.
} 
Já na cidade, o rapaz empenhou todos seus esforços nos estudos e, para se tornar Mestre-Doutor, de modo que foi convidado a assumir o governo do Reino dos Mexilhões. Depois de conquistar o cargo, assumiu a postura de Imperador e começou a ter atitudes ditatoriais. A primeira delas foi a de igualar a fala, para que o Reino tivesse uma só visão de mundo - a ideologia do Imperador, que visava ao controle, ou ao apagamento dos ideais da população. Conforme Marilena Chauí, ideologia consiste:

[...] precisamente na transformação das idéias da classe dominante em idéias dominantes para a sociedade como um todo, de modo que a classe que domina no plano material (econômico, social e político) também domina no plano espiritual (das idéias). [...]. Para que todos os membros da sociedade se identifiquem com essas características supostamente comuns a todos, é preciso que elas sejam convertidas em idéias comuns a todos. Para que isto ocorra, é preciso que a classe dominante, além de produzir suas próprias idéias, também possam distribuí-las, o que é feito, por exemplo, através da educação, da religião, dos costumes, dos meios de comunicação disponíveis. ${ }^{91}$

Parecia ser esse o intento do Imperador, que utilizou todos os recursos disponíveis de dominação, incluindo a criação de uma máquina de purificar palavras, cuja função era a de censurar aquelas que, segundo ele, podiam corromper o Reino e pôr em perigo todo o seu poder. Todavia, foi de sua própria invenção que veio o seu fim, porque foi exatamente no momento em que o Imperador perdeu o controle de uma palavra que se deu a ruína de seu Reino: "era o fim, que uma palavra tão trabalhada como Ordem, tão purificada, se pudesse transformar em Medo e ainda por cima mordesse."92 Após a desordem provocada pela "traição" da máquina purificadora, o Imperador-Dinossauro sofreu a humilhação de sucumbir envolvido pela fita de papel e, ao retornar de sua quasemorte, já existia em seu lugar outro imperador, assim como outros assessores. Então, o novo imperador resolveu criar um "império fictício", para que o antigo Imperador pensasse estar ainda no poder e os antigos conselheiros retomassem suas antigas funções no recém-criado "reino virtual", mas cheios de remorsos "por terem tido a infeliz ideia de pôr outro imperador no trono" ${ }^{\text {"93 }}$. Finalmente, o Imperador "a dado instante esqueceu-se que estava vivo e pronto. Faleceu"94. Por

\footnotetext{
${ }^{91}$ CHAUÍ, Marilena de Sousa. O que é ideologia. São Paulo: Abril Cultural / Brasiliense, 1984, p. 93-94.

${ }^{92}$ Ibid., p. 114.

${ }^{93}$ PIRES, José Cardoso. Dinossauro Excelentíssimo, cit., p. 128.

${ }^{94}$ Ibid., p. 143.
} 
fim, o Dinossauro acabou tragado pela própria ambição de dominar o Reino dos Mexilhões.

Essa narrativa se organiza em cinco partes. A organização temporal, com disposição circular da efabulação da narrativa, começa e termina no presente, mas apresenta retorno ao passado, a fim de esclarecer como se deu a ascensão do Imperador.

No Prólogo, o narrador revela ao leitor a sua intenção: contar o modo como um Imperador, ao manipular as palavras, perdeu o seu discurso, porque, na "ânsia de purificar as palavras, acabou por ficar entrevado com a paralisia da mentira" 95 .

No capítulo seguinte, "O homem que veio do nada", o contador relata a Ritinha a origem humilde de um mexilhão camponês que, através do saber e da autoridade, se tornou Imperador:

Supõe-se, está vagamente escrito, que esse imperador veio realmente do nada. Que nasceu algures numa choupana, filho de gente-nada ou pouca-coisa, camponeses ao desabrigo. Que muito possivelmente estudou por cartilhas de aldeia; por catecismos também. Mais: a acreditar nos compêndios das escolas, teria vindo ao mundo iluminado por Deus - e tanto assim que, ainda muito mocinho, fez ciência entre os doutores.

Nessa altura chamava-se Francisco ou Vitorino; Adolfo, talvez Adolfo Hirto; ou Benito Marcolino, Zé Fulgêncio, Sebastião Desejado - não interessa. O que interessa é que quando deram por ele já tinha outro nome: Imperador. Dinosaurus Um, Imperador e mestre. Palmas.

'VIVA O MESTRE IMPERADOR'

'VIVÓOÓ..." 96

No capítulo "O Reino", são narradas as ações do Imperador; nele também são descritos os habitantes do Reino, os mexilhões. $O$ narrador destaca, principalmente, a obsessão do déspota pela caça às palavras, principalmente àquelas que poderiam desdobrar-se em vários significados. Isso pode ser observado no poder da "censura" de apagar as palavras que fugissem à ordem prevista pelo caçador, pois, como foi

[...] doutor entre os doutores, a sua especialidade era as palavras. Dormia com elas desde criança e agora que estava sentado a governar começou a magicar um plano $[\ldots]$.

\footnotetext{
${ }^{95}$ PIRES, José Cardoso. Dinossauro Excelentíssimo, cit., p. 13.

${ }^{96} \mathrm{Ibid}$., p. 17.
} 
Dito e feito. Mãos ao trabalho, e ei-lo a limpar decretos e alíneas jornais, compêndios - o que calhava. Palavras correntes, mais vivas ou menos próprias, fogueira com elas porque pingavam de certeza veneno nas entre linhas. Outras, quase esquecidas nas rugas dos pergaminhos, essas é que sim: convinha ir buscálas, tirar o pó e lançá-las em circulação. [...]. Em suma, já que o reino era pobre o Imperador iria enriquecê-lo com palavras das melhores origens e criar uma linguagem geral que unisse o jovem ao velho, o rico ao necessitado, o mexilhão ao dê-erre. E boa sorte, desejava-lhe a História. ${ }^{97}$

Quanto tempo gastou o Imperador a estudar a maneira de se ver livre das palavras que incomodavam? [...] O melhor da vida, há quem diga. Bando de espiões batiam as ruas com o encargo de denunciar a língua, confraria de doutores mergulhavam nos compêndios, outros na letra de forma, no diz que diz. A fala dos mexilhões era passada a crivo, havia orelhas de morcego a caçá-la nas dobras da sombra, imagine-se. $^{98}$

Pertinaz nesse jogo de caça à palavra, o Imperador montou em seu gabinete a "câmara de torturar palavras", onde as submetia a um processo de "purificação". Criava assim uma realidade virtual, tecendo habilmente um novo imaginário, a fim de "pôr o Reino a falar numa língua limpa e severa em que todos se entendessem", 99 , porque "tudo lhe fazia crer que as pessoas ainda estavam longe de compreender o valor das palavras na construção da ordem e do bom-senso."100 De acordo com o esquema da câmara de torturar palavras,

Devidamente desdobradas nas suas origens e significados, as palavras eram transportadas por uma rede de canais progressivamente selectivos até um conjunto de três câmaras onde se submetiam a movimentos de compressão e síntese. O produto obtido, a reminiscência, a sílaba, ia sendo anotada numa

[...] Fita de registro contínuo e simultaneamente enviada para o

f) Complexo de Recuperação (lavagem e filtros) que, depois de purificar a palavra, a recompunha e transmitia aos

g) Ficheiros automáticos. ${ }^{101}$

Conforme o exame desse processo, podemos concluir que o Imperador, para submeter seus súditos, utilizava o "poder" da palavra para tornar o discurso obscuro, para distorcer os fatos a fim de criar um mundo "imaginado", espelhado de uma realidade configurada na superfície das palavras. Entre diversos episódios, citamos aquele em que o Tesoureiro das Arcas do Reino procurou o Imperador

\footnotetext{
${ }^{97}$ PIRES, José Cardoso. Dinossauro Excelentíssimo, cit., p. 50-51.

${ }^{98}$ Ibid., p. 55.

${ }^{99}$ Ibid., p. 51.

${ }^{100}$ Ibid., p. 52.

${ }^{101}$ Ibid., p. 57-58.
} 
para resolver a questão dos impostos. O Imperador retrucou ao tesoureiro com uma pergunta:

\section{'IMPOSTOS OU DONATIVOS?'}

perguntou o Imperador, insistindo na diferença. (Distinguo, disse até para ser mais claro.)

O das Arcas encolheu-se, mas Sua Alteza não perdeu tempo com ele: mais impostos era-lhe impossível autorizar; no entanto donativos achava bem. Não via inconveniente em que fossem decretados donativos que só os indivíduos de mais sentimentos ou os inimigos da pátria se recusariam a pagar. E com gente dessa nada de contemplações:

'CORTAM-SE-LHE AS ASAS.' 102

Em outro instante da narrativa, o Patriarca do Alto Comércio, desorientado quanto à atitude a ser tomada em relação aos pedintes do Reino, busca auxílio junto ao Imperador para, enfim, livrar-se deles:

[...] o que ali ia, o que ali ia. O homem mostrava-se desnorteado:

'NÃO POSSO MAIS, EXCELÊNCIA. OS EXCELENTÍSSIMOS MENDIGOS TIRAM-ME O SONO COM PEDIDOS.'

O Imperador encolheu os ombros. Trocou simplesmente a palavra: Mendigos? Quais mendigos? - E deu o problema por resolvido: inadaptados é o que o cavalheiro do alto comércio queria dizer. Inadaptados.

'E, POR AMOR A DEUS, INADAPTADOS SEMPRE EXISTIRAM E CONTINUARÃO A EXISTIR ATÉ NOS REINOS MAIS PRÓSPEROS. DURMA EM PAZ. ${ }^{103}$

Ainda nesse capítulo, o Imperador começava a transformar-se, numa primeira instância, em estátua, e depois, como veremos ao longo da fábula, num animal pré-histórico, um dinossauro.

Aquele imperador de bronze recordava-lhe o jovem doutor camponês, Modéstia e Autoridade, que viera do nada para assombrar os mestres. Olhava para longe, erecto como um promontório.

[...] Chefe! na expressão mais pesada e solene; o irmão-irmão, o gémeo; o que ficaria para os séculos como um vasto eco de panteão à meia luz. Isto, admitindo que alguma vez um Imperador e Mestre poderia ter irmão ou figura que lhe assemelhasse, QUE HERESIA! ${ }^{104}$

\footnotetext{
${ }^{102}$ PIRES, José Cardoso. Dinossauro Excelentíssimo, cit., p. 54.

${ }^{103}$ Ibid., p. 52.

${ }^{104}$ Ibid., p. 58-59.
} 
Ao Imperador de bronze era garantida a posteridade, pois ele se tornara uma estátua: o processo de distanciamento já se havia iniciado há tempos, ele estava cada vez mais distante das pessoas, vivendo de modo semelhante a de um ermitão, encarcerado em si mesmo:

[...] na cegueira de perseguir as palavras, Sua Alteza iria cair PRISIONEIRO! Tal qual. Encerrado no casulo. Visitas praticamente não tinha - dispensava. Falar, falava ele, mas para o gravador - compondo discursos à boca da teia, na madre palavras, portanto. ${ }^{105}$

Mas esse Imperador-Dinossauro envelheceu, assunto do capítulo "As palavras"; nele, o narrador descreve o Imperador como um homem velho e solitário, porque se tornou uma sombra do que fora. Continuava a promover discursos, mas em caráter privado, uma vez que "só no gabinete é que o Imperador cumpria agora o seu reinado. Escrevendo diante do retrato oficial, e a ouvir-se no altifalante, espelhado portanto no rosto e na voz."106 O Imperador se deixava enganar e não percebia seu envelhecimento e todas as transformações por que passava seu corpo e sua vida. Assim,

Imperador ermitão, num ruminar activo e secreto [...].Tempo depois quem visse os dois imperadores lado a lado, o de bronze e o de rosto de cera, perceberia os desgastes que os anos tinham trazido. Dobrado à secretária anos a fio, o Mestre criara bossas nas costas e como escrevia em largos comprimentos de onda para alômundos, murmurando as palavras, roendo-as ao correr da caneta, os lábios foram desaparecendo, sugados. A boca ficou ferida, os dentes em escama - um bicho.

'JESUS, COMO TU MUDASTE'

diria a mãe se fosse viva. ${ }^{107}$

Esse é um tempo em que o Imperador já não se interessava pelos assuntos do Reino, os quais estavam a cargo de seus conselheiros, mas continuava a fazer obsessivamente as depurações linguísticas: “Aprovava ou não e o que queria era voltar à teia [das palavras] rapidamente."108 Porém, sem que o Imperador esperasse, uma palavra escaparia à ordem, comprometendo toda a engrenagem montada há muitos anos. Tamanha decadência é traduzida pela cena patética em que o Imperador foi dominado pela serpente de papel e caiu no chão desacordado.

\footnotetext{
${ }^{105}$ PIRES, José Cardoso. Dinossauro Excelentíssimo, cit., p. 73.

${ }^{106}$ Ibid., p. 94.

${ }^{107}$ Ibid., p. $97-98$.

${ }^{108}$ Ibid., p. 112.
} 
"Queria desvencilhar-se e tropeçava em rolos de papel, de letras, de veneno, já nem sabia. [...] Tinha caído e estava velho; era um gigante muito antigo, de fibras mais que secas, a estalar."109

A essa cena, segue-se o "Epílogo", em que é revelado o acidente que resultou no coma do Imperador-Dinossauro, fato que acarretou várias mudanças na vida deste, começando por sua substituição pelo Imperador mais novo, pois, como os conselheiros acreditavam que o Imperador-Dinossauro morreria, começaram a criar um plano para manter o status quo no Reino. No entanto, o antigo Imperador "começava a despertar, a emergir." 110

Quando Dinosaurus, o Magnífico, acordou e se viu rodeado dos fidalgos habituais, a primeira coisa que fez foi pedir um espelho. Mirou-se, remirou-se, apalpando o rosto, reconhecendo-se. A seguir comunicou em voz sumida:

'PARA A SEMANA, REUNIÃO DO CONSELHO.'

$[\ldots]$

BICO CALADO!

Só que os conselheiros naquela altura também não eram conselheiros, tinham sido despedidos pelo novo imperador com pretextos de dá cá aquela palha. Alguns foram mesmo despachados para as cidades de província donde eram naturais

'MAS NÃO POR MUITO TEMPO...'

rosnaram eles porque estavam cheios de esperança numa re(vira)volta que talvez viesse. $^{111}$

Nesse capítulo, o Reino começava a apresentar, dentro do enredo, uma divisão entre o que seria virtual e o que seria real - recurso empregado com a finalidade de levar o Imperador-Dinossauro a pensar que ainda governava o Reino. Após relatar a coexistência simultânea entre esses reinos, o contador de estórias narra finalmente a morte do Imperador. Como o cadáver do ImperadorDinossauro fora restaurado para aparentar a imagem que ele tinha ao assumir o governo, seus súditos não enxergavam na aparência do personagem o seu Imperador, porque "Os mexilhões comuns quando o foram espreitar à urna de cristal abanaram a cabeça: acharam-no demasiado igual ao retrato para ser

\footnotetext{
${ }^{109}$ PIRES, José Cardoso. Dinossauro Excelentíssimo, cit., p. 114.

${ }^{110}$ Ibid., p. 127.

${ }^{111}$ Ibid., p. 131-132.
} 
verdade"112. Ao final da fábula, o contador da estória apresenta uma visão pessimista quanto às mudanças que possam ocorrer na relação entre o homem e o poder, visto que o novo Imperador dá continuidade ao sistema anterior. Entendemos, assim, que o narrador veicula a ideia de que o poder é uma máscara, que pode ser usada por muitos, mas mantém suas características, cumprindo sua finalidade. Por isso, os mexilhões mais velhos "lembravam aos filhos as estátuas que vigiavam o Reino. Segredavam: 'É ESTE, O DA MÁSCARA","113.

As análises realizadas em Dinossauro Excelentíssimo tendem a enfatizar sobretudo questões de ordem política e social. Em meio a uma rede de palavras, a máscara do Imperador pode ser desvelada pelo povo nesse Reino de Mexilhões. Logo, faremos uma incursão no mundo imaginário da fábula, e, entre dinossauro e mexilhões, indagamos: qual a matriz de aproximação da escrita de José Cardoso Pires com o gênero fábula? O que podemos aprender nesse reino de palavras?

\title{
3.1 A fábula
}

\begin{abstract}
Uma variante de realização alegórica é a "personificação" (fictio, personae, prosopopoeia), que consiste na introdução de coisas concretas, [...], assim como de noção abstrata e coletivas, [...], como pessoas que aparecem a falar e agir[...]. - Também a fábula de animais (fabula, fabella, apologus), pode ser igualmente incluída nesse tipo. ${ }^{114}$
\end{abstract}

$\mathrm{Na}$ ficção cardosiana, percebemos que o gênero é um procedimento de escrita, tem a característica de ser motivado, ressaltando as estratégias discursivas para atingir o seu objetivo, porque, para o autor, ou melhor, para o narrador de $O$ Delfim, "Cada romance tem as suas recordações à margem das aventuras que conta." 115 Se "el Estado narra" "116 , diz Piglia, "siempre imponiendo una manera de contar la realidad"117, cabe ao escritor-intelectual demonstrar que não "hay una

\footnotetext{
112 PIRES, José Cardoso. Dinossauro Excelentíssimo, cit., p. 143.

113 Ibid., p. 147.

${ }^{114}$ LAUSBERG, Heinrich. Elementos de retórica literária. Trad. R. M. Rosado Fernandes. 5. ed. Lisboa: Calouste Gulbenkian, 2004, p. 251.

${ }^{115}$ PIRES, José Cardoso. O Delfim, cit., p. 98. Cabe lembrar que, em Aristóteles, a diferenciação formal do gênero está relacionada à construção conteudística.

116 PIGLIA, Ricardo. Una trama de relatos. In: Crítica y ficcíon. Barcelona: Anagrama, 2001, p. 35

${ }^{117}$ Loc. cit.
} 
historia única y excluyente circulando en la sociedad ${ }^{118}$, pois o discurso literário, por não ser unívoco, é capaz de revelar as diversas versões de um fato, e, através delas, criar outros discursos, ou um contradiscurso, a trama de relato à qual se refere Piglia. Portanto, para esse autor,

Qualquer organização narrativa, acho eu, assenta no enquadramento de uma pluralidade de acções segundo determinado registro literário, mas a disposição dos eventos (a hierarquia que lhe é atribuída na descrição) afirma-se logo à partida como uma operação selectiva, ideológica. ${ }^{119}$

Cardoso Pires pretende, em sua obra, "contar a realidade" por procedimentos que a desvelem, mas sem revelá-la em sua plenitude, pois não tem a intenção de impor uma convicção política absoluta. Ao contrário, ele quer mostrar que numa rede social há diversos grupos ideologicamente ligados, os quais criam a malha social. $\mathrm{O}$ autor vem subverter a ordem, mostra-se revolucionário ao criar um diálogo entre a história oficial e o gênero literário fábula porque questiona simultaneamente o discurso que pretende ser dono de uma única "verdade", dominante, opressora, à qual esse discurso está vinculado.

Tratamos desse assunto anteriormente, ao estudar algumas das estratégias narrativas de Cardoso Pires. Verificamos que esse procedimento nos permite ler mais de uma estrutura em suas narrativas, porque seus escritos se constituem em um emaranhado complexo de textos dos mais diversos gêneros, estão ali presentes parábola, apólogo, ensaio, balada, romance policial - discursos que, arquitetados, organizam as estórias que Cardoso Pires quer contar. $\mathrm{O}$ autor prefere não se limitar a um gênero, mas desdobrá-los como se fossem mobili, ou pontos de vista sobre os temas a serem abordados, ampliando, assim, não só as perspectivas da estória contada, mas os próprios recursos literários. Para Maria Alzira Seixo,

O romance português da última década não se resigna ao espacejamento tradicional [...] se os anos cinquienta e sessenta foram já sensíveis a uma pluralidade de nivelamentos narrativos e ao relativismo temporal e subjectivo que lhe é condicionante, só estes últimos anos vêem constituir-se com evidência um novo discurso onde é justamente no plano da linguagem ou na articulação dos níveis efabulativos que a referida pluralidade se tenta. ${ }^{120}$

\footnotetext{
${ }^{118}$ PIGLIA, Ricardo. Una trama de relatos, cit., p. 35.

${ }^{119}$ PIRES, José Cardoso. Visita à oficina: o texto e o pré-texto, cit., p. 150.

${ }^{120}$ SEIXO, Maria Alzira. Dez anos de ficção em Portugal (1974-1984). In: romance: ensaios de genologia e análise. Lisboa: Horizonte, 1986, p. 57. A palavra do
} 
A reescritura do gênero fábula é possível e, ainda que o autor faça releitura alguns traços característicos da fábula clássica, o leitor é capaz de ativar em seu "repertório" aspectos da fábula, de sua relação com a ideia de "dizer sem dizer", ou seja, velar para denunciar. Nesse sentido, a fábula às avessas de Cardoso Pires cumpre a função de ser um discurso motivado pela História, isto é, uma alusão à ditadura salazarista, mas também à estória de oprimidos e opressores, comum ao enredo das fábulas. Isso pode ser verificado nas relações entre as características que o autor mantém da fábula "clássica" com a releitura que faz desses recursos técnico-literários, propondo outra visão desse código discursivo e em conformidade com o contexto em que o autor a produziu.

Etimologicamente falando, o vocábulo "fábula" é de origem latina (fabula, ae) e significa: conversa, boato, tipo de narração alegórica, relato em que há geralmente a atuação de animais e do qual se deduz um ensinamento prático ${ }^{121}$. Como observamos, esse significado guarda estreita relação com a "fala" conversa, boato, conversação -, referindo-se ao campo da oralidade, herança de tempos imemoriais. Para Ítalo Calvino, a fábula é “em sua sempre repetida e variada casuística de vivências humanas, uma explicação geral da vida, nascida em tempos remotos e alimentada pela lenta ruminação das consciências camponesas até nossos dias." 122 Para Carlos Reis e Ana Cristina Lopes, a fábula "designa um relato quase sempre breve, apontando para uma conclusão de dimensão ético-moral”"123, cuja função é ilustrar uma verdade universal, geral, com uma narrativa "concreta e particular". 124

Nos estudos da obra Arte poética, a palavra "fábula" apresenta dois significados distintos. Por um lado, designa a série ou o encadeamento de fatos que compõem a ação de qualquer narrativa; é associada à ideia de mito, pois, conforme a conceituação aristotélica, “é imitação de acções; e, por 'mito' (fábula), entendo a composição dos actos" $" 125$. Por outro lado, como gênero literário, a

${ }^{121}$ HOUAISS, Antonio; VILlAR, Mauro de Salles. Dicionário Houaiss da Língua Portuguesa. Rio de Janeiro: Objetiva, 2009, p. 865.

${ }^{122}$ CALVINO, Ítalo. Fábulas italianas. São Paulo: Companhia das Letras, 2005, p. 14.

${ }^{123}$ REIS, Carlos; LOPES, Ana Cristina M. Dicionário de teoria da narrativa. São Paulo: Ática, 1988, p. 209.

${ }^{124}$ PEREIRA, Luciano. A fábula, um género alegórico de proverbial sabedoria. . Forma Breve Revista de Literatura: A Fábula. Aveiro: Universidade de Aveiro, n. 3, 2005, p. 27. Disponível em: 〈http://revistas.ua.pt/index.php/formabreve〉. Acesso em: 8 ago. 2013.

125 ARISTÓTELES. Poética. Trad. Eudoro de Sousa. Lisboa: Imprensa Nacional / Casa da Moeda, 1986, p. 111. 
fábula é considerada uma narração breve, em prosa ou verso, cujos personagens são, geralmente, animais; como conto exemplar, alegórico, compreende um conselho, um princípio geral, ético, político ou literário, que se apreende nas entrelinhas da estória contada. De acordo com Flávio Kothe, a fábula é um texto alegórico que, por meio de elementos concretos, pretende exprimir uma ideia abstrata "que só é abstrata no sentido de escamotear suas raízes sociais e históricas para alcançar maior eficácia apresentando-se como a própria voz da transcendência". ${ }^{126}$

Em síntese, pode-se dizer que dois conceitos são admitidos para a fábula: o primeiro produz as imagens, que constituem a organização e a forma, a estrutura dinâmica e figurativa da ação; o segundo se refere aos conceitos ou às noções universais. Portanto, a fábula, livre da sua interpretação moral, apresenta uma variedade de sentidos, que se entrelaçam às reminiscências de histórias originais. Considerando-se as diferentes arquiteturas de suas estruturas básicas, as tessituras de narrativas essenciais, as diferentes materializações, as fábulas ensinam a contar, a narrar, "a refletir, a resolver contradições, enigmas, conflitos e dilemas, ensinam a ponderação, o esforço, o trabalho, a autonomia, a perspicácia e as virtudes intelectuais" ${ }^{\prime 27}$. Nesta tese, seguimos em busca desse aprendizado, promovendo a análise da fábula Dinossauro Excelentíssimo.

As fábulas são tão antigas como a própria história da humanidade; quase sempre anônimas, elas têm sido coletadas, adaptadas, reescritas ou apenas transcritas, ao longo de sua evolução histórica, por vários autores. Os relatos desse gênero apresentam como característica comum a presença de animais que falam, com o objetivo de transmitir um ensinamento, seguido de uma "moral" - frase ou expressão que exprime moralidade. Todavia, não é nosso propósito discorrer acerca dos fabulistas; objetivamos apenas fundamentar nossas análises, contextualizando-as.

$\mathrm{Na}$ evolução do gênero fábula, o primeiro dentre seus três períodos é caracterizado pela presença fundamental da moralidade, e tem origem nas fábulas

\footnotetext{
${ }^{126}$ KOTHE, Flávio R. A alegoria. São Paulo: Ática, 1986, p. 13.

${ }^{127}$ PEREIRA, Luciano. A fábula, um género alegórico de proverbial sabedoria, cit., p. 22-32.
} 
orientais $^{128}$, que passaram da Índia para China, Tibete, Pérsia e terminaram na Grécia, com Esopo. Esse lendário fabulista é considerado o "pai da fábula" no Ocidente, não porque ele a tenha criado, mas porque foi o primeiro a empregá-la, sistematicamente e com êxito, para ao mesmo tempo criticar, divertir, moralizar e instruir. Nas fábulas de Esopo estão presentes as seguintes características do gênero: a descrição de modo direto das virtudes e dos defeitos do caráter do ser humano, ilustrado por ações antropomórficas; a intenção pedagógica; e, principalmente, a brevidade relacionada à oralidade. Esopo tinha o objetivo de persuadir o ouvinte a agir conforme o bom senso, e, por isso, Aristóteles classifica a fábula esópica como a arte da persuasão, e não como a da poesia.

O segundo período evolutivo da fábula é marcado pela introdução das inovações formais feitas por Fedro. Foi ele quem fixou a forma literária do gênero fábula, escrevendo-a em versos. As histórias de Fedro são satíricas, conforme o gosto latino, contra os costumes e as pessoas da época em que viveu. José Perez, citado em prefácio para uma antiga edição de suas fábulas, ressalta que, se um sociólogo fizesse um estudo mais profundo da obra de Fedro, perceberia que, mais que intenções morais, havia "intuitos políticos com que o ferino fabulista fustigou os homens públicos e a depravação de seu tempo" ${ }^{129}$. Só em aparência Fedro copia Esopo. “A fábula parece a mesma. Mas não é. E não é porque na fábula esópica, Fedro, com rarezas de sutilidades, andou contrabandeando intenções de ásperas cruas críticas políticas. ${ }^{„ 130}$ Para confirmar sua hipótese, José Perez analisa algumas fábulas e exemplifica a tese que defende. Quem não vê

[...] na fábula do lobo e o cordeiro ${ }^{[131]}$ uma veemente apóstrofe contra sem razão brutal dos tiranos? Contra os déspotas daqueles tempos de todos, é a fábula das rãs

\footnotetext{
128 Pfromm Netto destaca: “A vertente ocidental da literatura fabular, embora seja convencionalmente centrada em Esopo (em grego) e Fedro (em latim), conta, no entanto, com contribuições anteriores. Encontra-se em Hesíodo (800 a. C.), por exemplo, a fábula do falcão e do rouxinol. As fábulas da raposa e do macaco e da vingança da raposa contra a águia são narradas por Arquíloco (séc. 7 a. C.). A história da águia castigada pelo escaravelho aparece em um fragmento de um poema de Simônides (séc. 6-5 a. C.)" (PFROMM NETTO, Samuel. Prefácio. In: FEDRO. Fábulas. Trad. Antônio Inácio de Mesquita Neves. Campinas, SP: Átomo / PNA, 2001, p. 4). Ainda nesse prefácio, Samuel cita Lesky para explicar que nenhum desses relatos é invenção dos poetas citados, pois Lesky afirma que esses poetas se inspiraram nas fábulas populares.

${ }^{129}$ PEREZ, José apud PFROMM NETTO, Samuel. Prefácio, cit., p. 5.

${ }^{130}$ Loc. cit.

${ }^{131}$ Fábula O Lobo e o Cordeiro: É fácil oprimir o inocente. Por sede ardente impelidos, / O feroz Lobo e o Cordeiro / Tinha vindo saciar-se / Na corrente de um ribeiro: / Água arriba aquele estava, / Longe - abaixo este ficava. / Súbito, as fauces inchando, / O quadrúpede voraz / Busca de rixa pretexto / E assim prorrompe falaz: / - "Por que turvas revolvendo / Est'água que estou
} 
pedindo um rei ${ }^{[132]}$. É mais do que espelhante a intenção. Uma feroz sátira de classe se cunhou para sempre na gralha soberba ${ }^{[133}$. [...] Em Roma toda gente se sentia aguilhoada pelo fabulário fédrico. ${ }^{134}$

Assim, diferentemente dos fabulistas que tentavam moralizar, Fedro direcionou seus objetivos mais para a sátira e a crítica, de modo a polemizar e a provocar o leitor para a reflexão.

O terceiro período da evolução da fábula é marcado por Jean de La Fontaine, autor de Les Fables, que retoma temas poéticos de Esopo, Fedro e outros fabulistas. Portanto, é a partir do modelo latino e oriental que ele introduz definitivamente o gênero na literatura ocidental. As fábulas de La Fontaine foram

bebendo?" / Contesta o manso Cordeiro: / - "Como, ó Lobo, ser assim, / Se a clara linfa que sorvo / Corre de ti para mim?" / Desta verdade a evidência, / Susto do bruto a inclemência. / "Há seis meses murmuraste / De mim", replica o insofrido. / - "Não pode ser, porque ainda / Eu não havia nascido." / - "Que importa!? Se és inocente, / Foi teu pai o maldizente." / E cerval, inexorável, / Sem que a inocência lhe importe, / Contra o mísero arremete, / Lacera-o, "té darlhe a morte. ??? - Nesta fábula o retrato / Se exibe dos prepotentes / Que com frívolos pretextos / Oprimem os inocentes. (FEDRO. Lobo e Cordeiro. In: . Fábulas, cit., p. 40-41).

${ }^{132}$ Fábula As Rãs pedindo um Rei - Dos males o menor: Outrora, quando Atenas florescia / Por suas sábias leis, por seus costumes, / Uma /irrequieta e falsa liberdade / A paz lhe perturbou, quebrando o encanto / Da disciplina antiga. Neste estado / Facciosos os partidos permitiram / Que o tirano Pisístrato ocupasse / Da República o trono: e como os Áticos / A condição de súditos chorassem, / - Não que ele os governasse asperamente, / Mas porque estranho caso era contê-los / Tão desusado jugo, e novas queixas / Cada qual por seu turno suscitasse, / Este apólogo Esopo lhes narrara: / "Vagando em livres lagoas / As Rãs, com grande alarido, / Pediram que o pai dos numes / Lhes desse um rei destemido / Que os dissolutos costumes / Contivesse, a braço erguido, / Do bando seu malsofrido. / Riu-se Júpiter e deu-lhes / Uma trave pequenina / Que, ao vau súbito atirada, / Dispersou terrorizada / Das Rãs a turba mofina. / Por largo tem esquecido / Jazia imerso no limo / O inofensivo rei fingindo, / Quando acaso uma das Rãs, / Pondo a cabeça de fora, / O quedo monarca explora, / E dele posta no cimo, / Convoca suas irmãs. / Então, qual mais petulante, / Todas, em nado, à porfia, / Investem sem cortesia / Contra o plácido reinante, / Covardes, vis, conspurcando / O inerte rei - miserando. / Entretanto a grandes brados / Um outro rei suplicaram, / Porque inútil fora aquele / Que os altos céus lhes mandaram. / Então a Júpiter prouve / Enviar uma serpente / Que uma a uma as devorava / Com rude e malino dente. / De resistir incapazes, / Debalde à morte fugiam / E de terror oprimidas / Nem sequer tugir podiam. / Neste transe, às escondidas, / Remetem Mercúrio a Jove, / Impetrando que este aprove / Socorrê-las - desgraçadas. / Então redargue o Tonante, / Do Olimpo nas cumeadas; / Com voz pausada e vibrante: / - "Pois que guardar não quisestes / O que tínheis tão bom rei, / Pelo mal que assim fizestes / O que tendes mau sofrei." / - Cidadãos, termina Esopo, / Vós também deveis manter / Este mal, para que um outro / Maior não venhais sofrer. (FEDRO. As Rãs Pedindo um Rei. In: . Fábulas, cit., p. 42-43).

${ }^{133}$ Fábula O Gralho Ensoberbecido e o Pavão (Cada um no seu lugar.) - Vangloriar-se alguém de alheios dotes / E à própria condição não dar valia / Condena Esopo, dando-nos o exemplo / Que concebeu em sua fantasia. / Todo ancho de si, todo soberba, / O Gralho certo dia arrecadara / As penas que ao Pavão caído haviam, / E com elas mui sécio se enfeitara. / Depois, tendo fugido aos seus iguais / Desdenhoso, intromete-se no bando / Formoso dos Pavões que mal o sentem, / Depenam-no a bicadas, crocitando. / Fugitivo, magoado, busca o triste / Voltar à sua grei; mas rechaçado, / Pungente afronta sofre dum daqueles / Que, havia pouco, tinha desprezado. / - "Se ser dos nossos fosse teu contento, / E não desses de mão à natureza, / Nem ultrajado foras por estranhos, / Nem dos teus repelido com dureza." (FEDRO. O Gralho Ensoberbecido e o Pavão. In:__. Fábulas, cit., p. 45-46).

${ }^{134}$ PEREZ, José apud PFROMM NETTO, Samuel. Prefácio, cit., p. 5. 
dedicadas ao Delfim de cinco anos, filho de Luis XIV, como disfarce astucioso para burlar as suspeitas censórias. Foram escritos "Panfletos cultos, denúncias cifradas e apelos subentendidos." 135 Além disso, o fabulista entendia que a função da fábula está em propagar desde a infância, de forma sutil, a virtude, para que o rei, o príncipe e, finalmente, o homem em formação, adquirissem conhecimento necessário ao seu próprio "auto-conhecimento e sobretudo ao da sua espécie" Analisando a obra de La Fontaine, Ribeiro afirma que o autor visava levar o leitor a aprender sem esforço aquilo que é necessário que um Delfim saiba.

La Fontaine interessa-se mais pela narrativa do que pela moralidade, que, por vezes, está nas entrelinhas de suas narrativas. No prefácio de sua primeira coletânea das Fábulas (1668), La Fontaine explica o porquê de escrever:

Sirvo-me de animais para instruir os homens.

$[\ldots]$

Procuro tornar o vício, ridículo,

Por não poder atacá-lo com braços de Hércules.

[...]

Algumas vezes oponho, através de uma dupla imagem,

$\mathrm{O}$ vício à virtude, a tolice ao bom senso.

[...]

uma moral nua provoca o tédio:

O conto faz passar o preceito com ele,

Nessa espécie de fingimento, é preciso instruir e agradar

Pois contar por contar, me parece coisa de pouca monta. ${ }^{137}$

Segundo Antonio Torrado ${ }^{138}$, as fábulas de La Fontaine são estilisticamente bem elaboradas, dotadas de flexibilidade poética, narrativa e dialogal ${ }^{139}$. Sobre as

135 TORRADO, António. Milhões de livros, biliões de vozes. Conto e Reconto: As Fábulas. Boletim Cultural. Lisboa: Calouste Gulbenkian, Série VIII, n. 2, p. 7, maio 1996.

${ }^{136}$ RIBEIRO, Fernando. Lessing: arte popular culta. In: Acta do IV Congresso Internacional da Associação Portuguesa de Literatura Comparada: Estudos Literários / Estudos Culturais, V. 2: Tradução, tradições e cânones. Lisboa: Universidade Nova de Lisboa, 2001, p. 3. Disponível em: <http://www.eventos.uevora.pt/comparada/VolumeII/LESSING.pdf>. Acesso em: 25 out. 2012.

${ }^{137}$ LA FONTAINE apud COELHO, Nelly Novaes. Literatura infantil. São Paulo: Ática, 1993, p. 147.

138 TORRADO, António. Milhões de livros, biliões de vozes, cit., p. 7.

${ }^{139}$ Fábula: O Lobo e o Cordeiro - La Fontaine - Estava o cordeiro a beber num córrego, quando apareceu um lobo esfaimado, de horrendo aspecto. /- Que desaforo é esse de turvar a água que venho beber? - disse o monstro arreganhando os dentes. Espere, que vou castigar tamanha má- 
Fábulas de La Fontaine, Pinheiro Chagas afirma: "O que constitui o seu encanto supremo é a vida potente que ele sabe dar a todos esses animais que se movem no imenso tablado da natureza, que falam a linguagem que ele lhe presta, obedecendo a paixões que lhes atribui." ${ }^{140}$ As fábulas de La Fontaine foram lidas por alguns autores $^{141}$, mas, nos séculos XVIII e XIX, muitos deles esquivaram-se de imitá$10^{142}$. No século XX, alguns escritores acreditam que a fábula encontrou novos caminhos, não só através dos desenhos animados, mas também na forma de paródias das fábulas clássicas, criando-se, assim, novos modos de interpretar os homens e suas ações.

Como já dito, a fábula, na vertente ocidental (escrita em prosa ou em verso), tem suas raízes na Antiguidade greco-romana. Encontramos em Fedro ${ }^{143}$ um ponto de partida para definir o gênero fábula: narrativa inventada cuja função é fazer refletir e ensinar por meio do riso, configurando seu tema nos diálogos entre árvores e animais. Chamamos a atenção para a fina ironia do autor, numa história de "gracejo divertido" criada com o intuito de ludibriar a censura:

Polir de Esopo as fábulas tentei

Em versos de seis pés que concertei.

Duplo valor encerra este livrinho,

Porque provoca o riso, enquanto ensina,

Em frase jovial, prudente e fina,

criação!... / O cordeirinho, trêmulo de medo,respondeu com inocência: / - Como posso turvar a água que o senhor vai beber se ela corre do senhor para mim? /Era verdade aquilo e o lobo atrapalhou-se com a resposta. Mas não deu o rabo a torcer. / - Além disso — inventou ele sei que você andou falando mal de mim o ano passado. / - Como poderia falar mal do senhor o ano passado, se nasci este ano? / Novamente confundido pela voz da inocência, o lobo insistiu: / - Se não foi você, foi seu irmão mais velho, o que dá no mesmo. / - Como poderia ser meu irmão mais velho, se sou filho único? / O lobo furioso, vendo que com razões claras não vencia o pobrezinho, veio com uma razão de lobo faminto: / - Pois se não foi seu irmão, foi seu pai ou seu avô! / E - nhoc! - sangrou-o no pescoço./ - Contra a força não há argumentos. (O Lobo e o Cordeiro. In: LA FONTAINE. Jean de La Fontain. Fábulas. Trad. Monteiro Lobato. São Paulo: Brasiliense, 1966, p. 50).

${ }^{140}$ LA FONTAINE. Introdução: Estudos Críticos. Fábulas de La Fontaine. Lisboa: Moderna Editorial Lavores, 2001, p. 5.

${ }^{141}$ Em Portugal, por exemplo, foram traduzidas por Bocage, Filinto Elísio, Curvo Semedo, entre outros.

142 A título de exemplo, podemos citar as fábulas de Florian (1755-1794), hábeis e graciosas, comparadas às de La Fontaine; as dos alemães Gleim (1719-1803) e Lessing (1729-1781); as dos ingleses Gay (1685-1732), Prior (1664-1721) e Dryden (1631-1700), e as do espanhol Iriarte (1750-1791).

${ }^{143}$ Caius Julius Phaedrus (15 a. C - 50 d. C., aproximadamente), de origem trácia, seria filho de um escravo que alcançou liberdade e independência. Muito jovem, foi para Roma, onde se ilustrou. Como poeta, introduziu na literatura latina a fábula, inspirando-se em Esopo, mas acrescentando-lhe uma viva intencionalidade crítica, com frequentes alusões a pessoas e aconteceres do seu tempo. A veia satírica fê-lo sofrer dissabores e conhecer o exílio. 
Da vida o refletido e bom caminho.

Se todavia alguém mal avisado

Censurar-nos quiser por ser estranho

Que as árvores e as feras em tamanho

Colóquio vivam, tenha bem lembrado

Que tudo quanto expomos é fingido,

Pura invenção, gracejo divertido. ${ }^{144}$

A fábula, para Fedro, apresenta duas funções: provocar riso e ensinar por meio de invenção, de fingimento, distanciando-se, desse modo, de qualquer relação possível entre o que o fabulista transfigura por meio de animais e os fatos "reais". No entanto, acreditamos que essa explicação está acrescida de fina ironia, cuja finalidade é simultaneamente questionar e burlar a censura.

Consoante o didatismo próprio da época, a estrutura da fábula, como subgênero retórico e prefixado, está dividida em duas partes: a primeira é uma breve exposição narrativa, em que personagens alegóricos, geralmente animais, protagonizam uma estória, cuja função é dar exemplo para reflexão posterior; a segunda apresenta breve conclusão, às vezes em uma só frase, ao modo de conselho ou de consideração de caráter moral, supostamente derivada do exemplo narrado. Além de trazer instrução e exemplo, a fábula encerra também um princípio ético e político. O objetivo das fábulas fédricas, segundo nossa concepção, pode também ser encontrado na fábula do Dinossauro.

\subsubsection{A retórica}

Como já destacado, a fábula teve propósitos diferentes ao longo da história. Na Grécia, foi utilizada como um recurso da retórica por Aristóteles, em sua obra Arte retórica, na qual o filósofo a apresentava como recurso persuasivo para os oradores. A fábula teve também a função de exaltar virtudes, sobretudo a prudência, e ainda a de alertar sobre o perigo de abuso de poder. Portanto, foi Aristóteles quem explicou o objetivo da fábula em uma argumentação retórica.

Fernando Ribeiro explica que a fábula

\footnotetext{
${ }^{144}$ FEDRO. Fábulas, cit., p. 39.
} 
[...] servia a retórica [...] sendo essencial às 'arengas públicas' tal como Aristóteles defendeu [...] vital à arte da persuasão. [...] A fábula mantinha uma relação estreita com a vida concreta, daí o ser expressão adequada ao discurso epidíctico ${ }^{[145]}$ pois proporcionava em excelência soluções perante questões pertinentes. ${ }^{146}$

O aspecto retórico da fábula pode ser assim explicado: ela parte de um exemplum - por meio de um texto -, a fim se de demonstrar um proposito através de uma afirmação de moralidade, cuja intenção é expressar uma "lição", revelando aos leitores como agir pelo bem e pela justiça.

Algo semelhante ocorre na fábula de José Cardoso Pires, em que ele parte do exemplo das ações de um ditador para demonstrar que não se deve aceitar as ações de um ditador, principalmente a censura da palavra. Em Dinossauro Excelentíssimo, o Imperador propagava suas ideias através da persuasão, fazendo uso de discursos para convencer o Reino de que tudo estava em ordem. No entanto, seu discurso tinha tão alto grau de complexidade que não conseguia atingir o público, e, por esse motivo, o Imperador passou a utilizar recursos retóricos mais concretos para mobilizar os súditos. Da narrativa, podemos citar um exemplum, empregado ironicamente com a finalidade de demonstrar um proposito, uma versão parodiada do discurso salazarista:

Durante largos dias o Reino ficou sobrevoado de florinhas de pólvoras e de canas de foguetes riscando as nuvens. As cartilhas de escola salpicaram-se de histórias de muito exemplo acerca da honra da pobreza e das desgraças que acontecem fatalmente aos ricos, no outro mundo. E então os mexilhões, muito bem calados, pensaram: pobrezinhos sim, mas honrados é que não. ${ }^{147}$

É fato histórico que, desde o início de seu mandato, Antonio Salazar buscava, através de seus discursos, persuadir a população a acreditar na humildade, pois ele não escondia sua origem de camponês que deixara sua aldeia para estudar em Coimbra e mais tarde se tornara chefe da nação. Podemos observar a relação entre o texto antes apresentado e o discurso proferido por Salazar em janeiro de 1949 no Palácio da Bolsa do Porto:

Devo à Providência a graça de ser pobre: sem bens que valham, por muito pouco estou preso à roda da fortuna, nem falta me fizeram nunca lugares rendosos, riquezas, ostentações. E para ganhar, na modéstia em que me habituei e em que

\footnotetext{
${ }^{145}$ Quer dizer: discurso de louvor ou censura a um personagem, a uma obra, etc.

${ }^{146}$ RIBEIRO, Fernando. Lessing: arte popular culta, cit., p. 3-4.

${ }^{147}$ PIRES, José Cardoso. Dinossauro Excelentíssimo, cit., p. 49.
} 
posso viver, o pão de cada dia não tenho de enredar-me na trama dos negócios ou em comprometedoras solidariedades. Sou um homem independente. ${ }^{148}$

A fábula, como discurso exemplar demonstra ser uma forma eficiente de provocar pensamentos críticos, de levar o leitor a refletir sobre a narrativa e sobre o mundo que o cerca. Embora pretenda persuadir, a fábula não perde seu caráter pedagógico, que é deixar evidente o saber sobre a realidade: o leitor sabe que se trata de ficção, mas isso não impede que ele remeta a uma realidade - portanto, possível -, afastando-se assim de abstrações enquanto permitir a analogia.

Importa ressaltar que encontramos na trama da fábula do Dinossauro Excelentíssimo características tanto de Fedro quanto de La Fontaine; deste, principalmente a questão relativa a "dizer sem dizer", de revelar, através da crítica irônica, as questões políticas; daquele, o caráter de ensino, de alerta aos leitores sobre si mesmos e sua história.

\subsubsection{A ironia}

De acordo com Cardoso Pires, fábula é "uma narrativa de sucessos inventados para instruir ou divertir"149, mas sabemos que, na escrita cardosiana, essa definição se desdobra numa função que "neutraliza a censura e desafia o leitor". ${ }^{150}$ Nesse sentido, a fábula não se apresenta apenas como gênero, mas também se constitui num singular recurso da ficção do autor, buscando rever a engrenagem da vida social, cultural e política de Portugal. O narrador relata a história de um Reino através da ironia, utilizando trocadilhos e linguagem ambígua com tom humorístico, como, por exemplo, no episódio em que descreve a rotina dos mestres na Universidade e ridiculariza o objeto que deseja atingir para intensificar a denúncia:

\footnotetext{
${ }^{148}$ SALAZAR, António. Discurso. Disponível em: <http://www.oliveirasalazar.org/frases.asp〉. Acesso em: 8 ago. 2013.

${ }^{149}$ Esse conceito é encontrado no posfácio da fábula $O$ anjo ancorado (PIRES, José Cardoso, cit., p. 150).

${ }^{150}$ BRIESEMEISTER, Dietrich. A técnica de codificação histórica no romance O Delfim (1968), de José Cardoso Pires. Semear. Rio de Janeiro: Cátedra Padre António Vieira de Estudos Portugueses da PUC-Rio, n. 11, p. 81, 2005.
} 
Cada qual empunhava o seu bastão de igreja mas sem a volta dourada dos báculos; e à maneira de mitra tinha sobre os joelhos um chapéu conhecido por capelo que só cabe na cabeça dos muitos sabedores e não na de qualquer dos estudantes que circulavam cá em baixo, decorando a sebenta:

'PATITI... PATITÁ... NOVES FORA, NADA.

PATITI... PATITÁ... NOVES FORA NADA.'

Diga-se ainda que naquela casa havia muito latim pelas portas, patiti e pelas paredes, patitá, e que se falava constantemente a pensar nos mortos, no salutar exemplo dos mortos, nossos maiores,

'AD GLORIAM DEI!'[151]

e sempre com maior respeito ${ }^{152}$

Desse modo, compreendemos que Cardoso Pires, ao inventar um Reino às avessas, não quer somente divertir, mas também instruir, denunciar, ainda que de forma irônica, as dificuldades sofridas pela sociedade portuguesa, porque nesse Reino o povo vive oprimido, assolado pelo frio e pela fome:

O Reino naquela época tremia de frio e de dificuldades. Tinha-se deslocado para a beira-mar, não se sabe bem porquê mas supõe-se: fome. A fome vinha do interior e varria tudo para o oceano.

Nesta leva desgarrada, escapavam os camponeses, que tinham a barriga curtida, eram cardos, e que se cravavam na terra à dentada, como uns danados. Espalmavam-se nas tocas e nas dobras das montanhas para deixar passar a ventania, pareciam calhaus, seres empedernidos; depois voltavam ao trabalho, à semente que se enterra e ao fruto que se arranca. Tinham-se habituado de tal maneira à má sina que fome para eles era o pão de cada dia.

Os restantes, os que não conseguiam enganar os vendavais, fugiam de roldão pelo país, atravessando aldeias e planícies, vinhas e repartições, hoje fazendo família neste ponto, amanhã mais naquele, até se verem diante do mar, acossados. Uma vez ali, ou entregavam o corpo aos caranguejos ou faziam como o mexilhão: pé na rocha e força contra a maré. Daí o nome de Reino do Mexilhão que lhe pôs a geografia em homenagem (homenagem?) a esse marisco mais que todos humilde, só tripa e casca. ${ }^{153}$

A homenagem citada nesse fragmento, referente ao Reino dos Mexilhões, interroga o enredo de fatos históricos sob uma nova perspectiva: os mexilhões são trabalhadores, humildes, vivem torturados entre os espaços das ondas e sobrevivem com medo, frio e fome, agarrados às rochas, lutando contra a maré num movimento de resistência ao tempo, ou seja, à História.

\footnotetext{
${ }_{151}^{151}$ Significa "para glória de Deus".

${ }^{152}$ PIRES, José Cardoso. Dinossauro Excelentíssimo, cit., p. 36.

${ }^{153}$ PIRES, José Cardoso. Dinossauro Excelentíssimo, cit., p. 41.
} 
De acordo com Fedro, a opressão ${ }^{154}$ motivou a necessidade de se criar um texto engenhoso, cujo intuito era denunciar o jugo a que a população daquela época era submetida. Logo, o "poeta" insubmisso ousava dizer o que queria, esquivando-se da punição por meio da imaginação e da galhofa. Assim, a esse caráter da fábula - gênero literário que apresenta em sua origem a idéia de subversão -, acrescenta-se a função de exemplo ${ }^{155}$, semelhante à do provérbio, à do mito, à de estórias exemplares. Cardoso Pires assim discorre sobre a função das estórias exemplares: “Seria, antes [...] uma 'história de proveito e exemplo' - um romance, no sentido tradicional do termo, destinado unicamente a ilustrar uma legenda, uma moral ou um clima humano, para lá de qualquer imediatismo de tempo e de lugar histórico."156 Essas histórias de "proveitos e exemplos" que permeiam a fábula fazem parte do já referido "recurso do descritivo", entendido como recursos intertextuais que exercem a função de acrescentar ao texto pequenos indícios ou cifras a serem identificadas pelo leitor. Em Dinossauro Excelentíssimo, embora não se utilize de uma estrutura policial para investigar o passado histórico de Portugal, Cardoso Pires traz para a fábula temas que envolvem, ou se relacionam, às questões históricas e políticas do país. O narrador as apresenta como um "enigma da palavra”, pois é através das palavras e pela palavra que o mistério é criado pelos personagens desse Reino.

\section{'QUANDO O MAR BATE NA ROCHA \\ QUEM SE LIXA É O MEXILHÃO.'}

Criatura (porque o é), criatura à margem, mirrada, coisa pequena; bicho que se alimenta de água e sal, do sumo da pedra, ou de milagres, quem sabe - o mexilhão, oh vida, tem a ciência certa dos anónimos: pensa e não fala, vai por si. Se virou costas à terra foi por culpa dos dê-erres e da conversa em bacharel com que o atacavam; unicamente por cansaço, desinteresse. Agora na sua condição de habitante do litoral era como o oceano que desabafava, levava os dias a medir o infinito e a resmoer o seu ditado preferido: Quando o mar bate na rocha quem se lixa é o mexilhão.

Um estrangeiro, mesmo o mais turista dos estrangeiros, não podia deixar de concordar que havia muita verdade no provérbio. Logo que nos outros reinos se

154 Qual causa deu às fábulas origem. / - Tolhida de expender quanto sentia / A opressa escravidão, nos apológicos / Pequenos contos, procurou disfarces / Com que desafogar seus pensamentos / E a calúnia burlar com fio engenho (FEDRO. Fábulas, cit., p. 87).

155 Para Lausberg, exemplum é um domínio mais finito do simile, que consiste num fato fixado historicamente (ou mitologicamente, ou literariamente), o qual é posto em comparação com o pensamento propriamente dito (LAUSBERG, Heinrich, 1972 apud ROCHA, Clara. Para uma leitura dos "contos exemplares". Máthesi. Viseu: Universidade Católica Portuguesa, n. 10, 2001, 30).

${ }^{156}$ PIRES, José Cardoso. apud COELHO, Nelly Novaes. José Cardoso Pires - O Delfim: uma obra "aberta". In: Escritores portugueses. São Paulo: Quíron, 1973, p. 154. 
declaravam guerras ou preços lá vinha o vento a alastrar e quem pagava eram os mexilhões, apesar de não terem culpa nenhuma; se os serranos se deixavam arrastar das suas tocas, sabiam que era contra eles que vinham chocar e viam-se obrigados a fazer parede para não se deixarem devorar. Oh, vida. ${ }^{157}$

Alguns críticos afirmam que é tendência marcante, na obra de Cardoso Pires, apresentar ou partir de pequenas estórias exemplares para propagar o conhecimento dos fatos e transfigurá-los em "exemplo", o que também pode ser observado em Dinossauro Excelentíssimo. Nessa obra, a legenda defendida pelo autor ultrapassa a idéia de simples "testemunho", porque Cardoso Pires utiliza o mesmo método de Matisse, que "nunca pintava as coisas mas as relações entre as coisas" ${ }^{\prime 158}$. Logo, o autor não pinta uma cena portuguesa; antes, busca revelar as relações existentes na malha discursiva que paira sob a fábula, construída no entrelaçamento da história factual e das versões paralelas - expressas por meio de provérbios, exemplos, apólogos, cuja tendência cristalizadora é rompida quando as versões tendem a desmistificar essa cristalização.

As estórias exemplares, ainda que, num primeiro momento, pareçam narrativas fechadas, são efetivamente narrativas "dobradas", que, ao se movimentarem, giram como os mobili e nos dão a ver várias possibilidades, ou múltiplas perspectivas. Portanto, Dinossauro Excelentíssimo é exemplum - uma ilustração do "poder de censura", como esclarece a fala de um personagem: "Já ensinavam os mexilhões-avós e os mais para trás que fingir de cego é virtude de quem vê demais, e certamente tinham razão" ${ }^{159}$ - e também uma releitura da História pela ficção, uma reflexão sobre a História oficial. Neste fragmento do texto, verificamos a alusão ao Reino, à figura de Salazar e à ditadura:

Como se disse, desiludido dos camponeses excursionistas e dos habitantes da capital (que eram excursionistas ao contrário porque mal lhes cheirava a discurso emigravam para o campo) o Imperador atirou-se com raiva dobrada às palavras.

Continuava a discursar - mas em privado, no gabinete. A voz escrita e gravada seguia direitinha aos continentes universais através das agências telex e do telégrafo traço-ponto; entrava em órbita, perdurava já distante das leis da terra como um eco... eecooo... Logo pela manhã o Imperador encontrava-a reproduzida nos jornais, e era admirável no fraseado e no subentenda-se, o pensamento a desdobrar-se. A rádio e a televisão transmitiam-na entre marchas invencíveis e compassos de procissão, um-dois, esquerda-direita, Laus Deo; o altifalante do

\footnotetext{
${ }^{157}$ PIRES, José Cardoso. Dinossauro Excelentíssimo, cit., p. 42-43.

${ }^{158}$ PIRES, José Cardoso In: PORTELA, Arthur. Cardoso Pires por Cardoso Pires, cit., p. 69.

${ }^{159}$ PIRES, José Cardoso. Dinossauro Excelentíssimo, cit., p. 75.
} 
gabinete despejava-a continuamente. A voz, senhores, as palavras que ele escolhera e implantara, chegava-lhe da boca dos excelentíssimos da Comarca dos Doutores, reflectida. ${ }^{160}$

De acordo com essa ótica, a noção de fábula vem se caracterizar como um pronunciamento político e didático, porque, ao mesmo tempo em que os leitores na figura de Ritinha - ouvem o contador de estórias, assimilam a memória cultural portuguesa. A partir de então, podem refletir sobre a temática e sobre os mecanismos com os quais se constrói a imagem do poder e da censura no discurso do narrador.

$\mathrm{Na}$ narrativa em análise, sob a pena de José Cardoso Pires, pode ser evidenciada uma visão particular da ditadura, de forma que tanto o ditador quanto outros aspectos sociais e políticos do governo são transfigurados em fábula. Em função desse procedimento, podemos delinear o universo fabular em virtude da presença de certos elementos encontrados no gênero fábula: seres humanos metaforizados em animais, que se confrontam; espírito realista e irônico; atemporalidade; oralidade. Acrescenta-se a essa dimensão fabulística o emprego de temas universais abordados de modo peculiar, tais como: o poder e sua construção periférica; a censura como tentativa de homogeneizar o discurso do reino; a insubmissão das vozes caladas; a reflexão sobre o fazer poético referente à impossibilidade de fabular.

\subsection{Os fios que tecem a fábula}

Nas mudanças de reinado Mudam apenas os pobres, Ao invés dos que são nobres

O nome do potentado.

Desta fábula o conceito Protesta à verdade preito.

Fedro $^{161}$

Em Dinossauro Excelentíssimo, encontramos elementos do gênero da fábula clássica, assim como sua revisão a partir do ponto de vista cardosiano, que traz para o presente a adaptação de um gênero milenar. A transfiguração fabulística

${ }^{160}$ PIRES, José Cardoso. Dinossauro Excelentíssimo, cit., p. 93-94.

${ }^{161}$ FEDRO. Fábulas, cit., Livro I, fábula XV, p. 57. 
que norteia a narrativa cardosiana apresenta vários níveis de composição. Suas linhas se entrelaçam a partir da presença de várias características próprias tanto da versão clássica desse gênero quanto da sua atualização sob um novo contexto, numa releitura da fábula na literatura contemporânea.

Dentre as características que compõem a fábula cardosiana, encontramos a presença da oralidade, caracterizada pelo relato da estória, que se inicia com um pai contando uma estória para a filha: "Hoje em dia pode-se roubar tudo a um homem - até a morte. [...] - disse o contador de estórias à sua filha Ritinha"162; a metamorfose do Imperador em "monstro de sapiência"163 - em Dinossauro -, em decorrência da sua obsessão por manipular as palavras; a animalização dos seres humanos, que se dá por meio da comparação, quer pelos traços físicos, quer pelas atitudes - mexilhões, morcegos ou os "Dê-erres", metonimicamente associados a um animal, pois, nesse episódio, esses últimos personagens têm seus gestos ligados ao campo semântico do cavalo.

Seguiam um caminho elevado e muito histórico, nada de coices ao desbarato. [...] Os notáveis não esmoreciam. Continuavam a afiar o casco da unha nos dicionários, esmagando os termos que o Imperador ia abatendo no gabinete. [...] Finalmente, quando se consideravam afinados, desataram a discursar à rédea solta. ${ }^{164}$

Nessa fábula, entre os intertextos convocados, salientam-se os elementos próprios de contos infantis como a alusão a bruxas: "mesmo para as bruxas de unhas reviradas, devia ser complicadíssimo acertar nas cartas do destino" ${ }^{\text {"165; a }}$ fadas madrinhas: "estava nisto quando, pézinhos mansos, tec-tec, apareceu a Dona Madrinha" "166; a citação de monstros. Considerando-se esse contexto, a figura do Dinossauro lembra a do dragão que aparece em alguns contos de fadas, para além de marcas linguísticas, a exemplo de "E UM BELO DIA...""167. Encontramos também uma citação ao espelho mágico, importante elemento do conto de fadas Branca de Neve e os sete anões, em que o narcisismo da madrasta - evidenciado pelas várias consultas feitas ao espelho - constitui a propulsão da ação na história. Em Dinossauro Excelentíssimo, os espelhos ensinados do Imperador o

\footnotetext{
162 PIRES, José Cardoso. Dinossauro Excelentíssimo, cit., p. 13.

163 Ibid., p. 100.

${ }^{164}$ Ibid., p. 74.

${ }^{165}$ PIRES, José Cardoso. Dinossauro Excelentíssimo, cit., p. 22.

${ }^{166}$ Ibid., p. 20.

${ }^{167}$ Ibid., p. 24.
} 
acompanham e refletem gradativamente a perda de visão do mundo real, porque, conforme o revelado por esses "espelhos especiais", um mundo imaginário é criado pelo Imperador do Reino dos Mexilhões. Depois da metamorfose do Imperador em Dinossauro (fase de envelhecimento), o espelho irá enganá-lo. Há, portanto, uma relação direta entre o espelho do conto de fadas citado e os espelhos ensinados da fábula de Cardoso Pires, porém eles oferecem sentidos opostos: enquanto o primeiro revela as imagens, o segundo tende a iludir o Imperador. A pergunta que a rainha madrasta faz ao espelho mágico do conto é aqui refeita em tom irônico, o qual toma conta do episódio da fábula.

Em todo caso, por medo ou por dedicação os conselheiros resolveram que a imagem final não seria a do Dinossauro ermitão mas a do Imperador conforme a estátua. [...]. E para que ele ficasse de sempre, por cima da idade, arranjaram maneira de meter na Torre das Sete Chaves uns espelhos especiais que corrigiam a imagem do Doutor Dinossauro [...]. O Imperador logo de manhãzinha arrastava a figura de dinossauro e dava os bons-dias a si mesmo diante dos espelhos. Perguntava:

'ESPELHO, FIEL ESPELHO, ONDE É QUE NESTE REINO HOUVE ALGUÉM QUE DESAFIASSE O TEMPO COMO EU?'

'JAMAIS, SENHOR, JAMAIS, A VIDA REGRADA, O SABER E A PALAVRA TORNAM O HOMEM IMORTAL',

respondiam os espelhos ensinados. ${ }^{168}$

Desse modo, na narrativa de Cardoso Pires, destacamos mais uma das características do gênero fábula: a personificação de objetos inanimados. Além desses espelhos que travam diálogos com o Imperador, a velha carripana é comparada a um jumento, pois "a carripana parece que a ouvia [...] ainda por cima estava ruça, que desgraça, ruça e cheia de feridas [...] podia até amuar e recusar-se a ir para diante, cheia de personalidade. Como os jumentos, afinal."169

Evidenciamos ainda as palavras metamorfoseadas, as que podem destilar veneno nas entrelinhas, as "palavras correntes, mais vivas ou menos próprias" "170; a humanização do computador através da personificação de seus elementos: "olhos eletrônicos, cabelos de platina"171; o poder da voz que "nascia na tribuna, vinha do alto, ou ia para o alto, lançada pelas bocas de um exército de altifalantes

\footnotetext{
${ }^{168}$ Ibid., p. 100-103-104.

${ }^{169}$ PIRES, José Cardoso. Dinossauro Excelentíssimo, cit., p. 28.

${ }_{1770}^{17 b i d ., \text { p. } 51 .}$

${ }^{171}$ Ibid., p. 55.
} 
apontados às nuvens do inconcebível" "172; a palavra recém-caída na teia e os olhinhos duros do Mestre que, fixando-a, "Via-a [a sílaba] correr como doida, ora a comprimir-se, ora a inchar, denunciada continuamente na fita de registro que saía dos computadores"173; e, finalmente, a fita de papel em serpente: "a fita escorreu mais depressa dos computadores. Serpenteava pelo chão, enroscava-se nas pernas do Douktor." 174

Compreendemos que no texto está presente a dimensão moral e pedagógica, ainda que nas entrelinhas. Afinal, a fábula "era um reino a vender o abstrato, a negociar o talvez" ${ }^{\prime 175}$. Em certas ações narradas, identificamos a inversão da moral de vários provérbios inclusos na fábula: “'mais vale um rico na mão do que dois pobres a voar""176 , em vez de "Mais vale um pássaro na mão do que dois voando". O narrador explora, no provérbio, a questão do acúmulo de bens materiais interpretação que o Imperador desvirtua, porque centraliza sua visão no homem pobre, quando sabemos que o contador de histórias deseja enfatizar o ponto de vista do Imperador, para quem os que mais valiam eram os ricos, e não os pobres. Outro exemplo desse tipo de emprego de provérbios é: "Fingir de cego é virtude de quem vê demais", provérbio que nos remete a outro: "Em terra de cego, quem tem um olho é rei”, o qual associa a esperteza à visão com a intenção de tirar proveito ou acautelar-se de algo. Naquele citado em Dinossauro Excelentíssimo, ocorre o contrário, porque enxergar demais pode ser perigoso, melhor seria fingirse de cego, ou calar-se diante do observado ${ }^{177}$.

\subsubsection{A voz}

A predominância das marcas da oralidade é característica corrente nas fábulas, precisamente por serem elas textos de tradição oral. Foram difundidas oralmente, "contadas"; por isso, havia o predomínio de linguagem simples, de fácil entendimento e memorização, com efabulação básica e às vezes constituída

\footnotetext{
${ }^{172}$ Ibid., p. 82.

173 Ibid., p. 95.

174 Ibid., p. 113.

175 Ibid., p. 47.

${ }^{176}$ Ibid., p. 50.

${ }^{177}$ PIRES, José Cardoso. Dinossauro Excelentíssimo, cit., p. 75.
} 
por diálogos. Ao incorporar a oralidade na construção de sua fábula, Cardoso Pires cria núcleos de oralidade, empregando certos recursos para bem expressar os diálogos, ainda que implícitos, entre o fabulista e o ouvinte. Às vezes, esses diálogos são entremeados de recorrências à entonação, de modo que os ecos são traços que podem ser observados nas poucas falas das personagens, quando escritos, por exemplo, com letras maiúsculas. Neste fragmento, tal recurso nos dá a impressão de que alguém está gritando; em outros, encontramos redundâncias através de intervenções explicativas: "e não sei se me faço compreender"178.

Nessas ocasiões soltavam gritos de guerra:

"EFE-ERRE-A... FRA!"

"EFE-ERRE-E... FRE!"

"EFE-ERRE-I... FRI!"

procurando assim recordar o abecedário.

Longe, nos quintais, os que não andavam de tesoura em punho cantavam para chamar mulher. E, Jesus, era de arrepiar. Ouvia-se a guitarra: gemia tremidos, miudinha; ouvia-se a voz: tinha trinados de ave capada, toda mel e lua cheia. Estava-se, escusado será dizer, NA CIDADE DOS DOUTORES.

Das esquinas e dos portais, os três forasteiros eram assaltados por comerciantes da mais variada espécie:

"PTS, DOUTORES!" 179

Desse modo, Cardoso Pires reproduz na sua fábula a oralidade, empregando as marcas do prosaísmo que a aproximam muito da linguagem do cotidiano. Em suas obras, o autor tende a aproximar o leitor de seu texto; por isso o nível de linguagem na fábula varia tanto quanto os personagens: "Para quê igual?, pergunta a nossa curiosidade" ${ }^{, 180}$; talvez seja uma estratégia do narrador para manter o leitor incluso ao texto.

Quando os textos orais ${ }^{181}$ foram fixados à linguagem escrita, procurou-se adaptá-los de modo que mantivessem alguns traços da oralidade, e logo inseriramse os recursos que a reproduzem: os sinais de pontuação, as pausas, as frases curtas com estruturas simples e linguagem coloquial, como a expressão "ORA

${ }^{178}$ Ibid., p. 44.

${ }^{179}$ Ibid., p. 32-33.

${ }^{180}$ PIRES, José Cardoso. Dinossauro Excelentíssimo, cit., p. 123.

${ }^{181}$ Além das fábulas, também os contos populares, as lendas e as várias narrativas hoje já fixadas à escrita têm origem na oralidade. 
GAITA!" 182 , dentre outras. Além dessa estratégia, os traços próprios da linguagem oral fixados à escrita são evidentes nas onomatopeias: "Pilhas e oratórios, pííízzzmmm... oratórias, palmas, oh pátria... pííí-zzzmm..."183, ou "Os sinos [...] reproduziam-se como sementes levadas pelo vento BADALÃO... BADALÃO..." "184; nas observações irônicas do narrador: "Também não quis família nem amigos; festas e multidões de-tes-ta-va"185, ou "Mas, como diz o outro, o amor dos pais tudo vence" 186 , ou ainda "sofreram muito para fazer a viagem, pobres deles" $" 187$.

Em determinadas passagens do texto, o discurso direto é posto de lado. Surge em seu lugar um discurso que lembra o coro das tragédias gregas, como se quem de fato falasse fosse uma voz social, e não apenas a dos personagens.

Por último, os habitantes da aldeia, levados pela inveja e pela intriga, tinham-se posto a insultar os pais sacrificados que, na opinião deles, não passavam de uns perdulários a correr atrás do sonho de um filho doutor.

"LOUCOS! GANANCIOSOS!"

"REGENADOS!"

"MÃOS ROTAS!" 188

Isso ocorre porque na fábula raramente é dada voz aos personagens, possibilidade deles manterem diálogos entre si. Essa estratégia é perfeitamente explicável porque paira sob a fábula o murmurinho silencioso da rede de vozes sufocadas. Mesmo aos dê-erres só é permitida a repetição; por esse motivo, "O Mestre, lendo-os ou ouvindo-os albardados com as frases imperiais, fazia de conta que não percebia que se estava a ouvir."189

Alguns autores acreditam que, ao reproduzir a oralidade na escrita, a narrativa acompanha o ritmo do pensamento, contínuo, buscando acompanhar o “contar" como acontece na realidade: "diante do espetáculo da capital, ficava de boca aberta, bah!, em-basba-cada"190, ou "Caramba, aqui os outros engoliram em

\footnotetext{
182 PIRES, José Cardoso. Dinossauro Excelentíssimo, cit., p. 127.

${ }^{183}$ Ibid., p. 133.

${ }^{184}$ Ibid., p. 46.

${ }^{185}$ Ibid., p. 50.

${ }^{186}$ Ibid., p. 24.

${ }^{187}$ Ibid., p. 23.

${ }^{188}$ Ibid., p. 24.

${ }^{189}$ PIRES, José Cardoso. Dinossauro Excelentíssimo, cit., p. 74-75.

${ }^{190}$ Ibid., p. 76.
} 
seco. Palavras difíceis... otorrinolaringologia... abacadabrante... répcio... $\mathrm{E}$ daí?"'191

Outro aspecto da oralidade presente na narrativa é o recurso ao monólogo interior, que possibilita descrever os pensamentos dos personagens à medida que surgem em sua mente. Esse discorrer de ideias é reproduzido como se fosse um discurso pronunciado em voz alta por alguém que trava diálogo com o leitor sobre a hierarquia no Reino.

Concluímos que o recurso da oralidade está aqui representando uma voz velada, de denúncia, pois, apesar de o silêncio ser imposto ao Reino, ele é rompido justamente pela "voz" de um contador de estória. A oralidade e o contar estórias, na fábula Dinossauro Excelentíssimo, são características privilegiadas por Cardoso Pires, que recupera um recurso milenar de propagação de idéias: as "versões orais". A fala dos mexilhões é passada a crivo: "havia orelhas de

morcego a caçá-la nas dobras da sombra, imagine-se". ${ }^{192}$ É oportuno referir que o morcego, ainda que não tenha o sentido da visão aguçado, é capaz de guiar-se seguindo o impulso de ondas sonoras; por isso, parece-nos oportuna a escolha desse animal para representar metaforicamente a PIDE, ou seja, a polícia política de Salazar, responsável por delatar a fala insubordinada. Portanto, o "contador" José Cardoso Pires se assemelha a um mexilhão descontente, por retomar a cultura popular vinda da fábula a fim de manter a atenção do leitor e, ao mesmo tempo, promover uma reflexão sobre valores que foram esquecidos, negligenciados, ou invertidos pela sociedade em determinado período da história.

\subsubsection{A cifra}

A moralidade, que engendra conceitos ou noções gerais a respeito dos seres humanos e de seu convívio em sociedade, não representa a única chave da fábula, mas pode ser o seu ponto de partida. Trata-se de um enigma que se propõe ao leitor, apontando-lhe índices, revelando outras possibilidades de compreensão do

\footnotetext{
${ }^{191}$ Ibid., p. 23.

192 Ibid., p. 55.
} 
mundo e da vida que a narrativa oculta desde o início. Segundo Ítalo Calvino, a moral da fábula está

[...] implícita, na vitória das virtudes simples das personagens boas e no castigo das perversidades igualmente simples e absolutas dos malvados; quase nunca insiste nisso de forma sentenciosa ou pedagógica. E talvez a função moral que a narração de fábulas tenha no entendimento popular deva ser buscada não na direção dos conteúdos, mas na própria instituição da fábula, no fato de contá-la e ouvi-la. E isso pode também ser entendido no sentido de um moralismo prudencial e pragmático. ${ }^{193}$

Nesse sentido, o leitor-ouvinte é convidado a ler-ouvir a fábula como um jogo em que a "moralidade" é frequentemente entrevista na voz de um personagem ou do próprio contador de estórias. Este pode exercer a função do "coro" das tragédias clássicas, personagem coletivo cuja finalidade é a de antever o desenrolar dos fatos, comprovar ou aconselhar como porta-voz de "sábia experiência”. Portanto, o porta-voz da moral interfere, amiúde, para constatar algo, ou para aconselhar: "Não olhes o semelhante com desprezo porque pode ir ali uma sorte grande"194, ou "Os conselheiros, com seiscentos diabos, marinharam pelas paredes, bravíssimos, porque já tinham arranjado outro imperador. [...] $\mathrm{E}$ agora? Agora, para a frente e cara alegre"195; outras vezes, pode instruir: "Cada terra dá o que tem, a mais não é obrigação. [...] A cidade para onde se dirigiam os três camponeses produzia doutores - e isto não consta da Geografia. Toma nota, Ritinha."196

Observamos também certos desígnios sentenciosos, emitidos por alguns personagens, que são claramente representações metonímicas de uma classe social, como o padre, a madrinha e o regedor:

Dinossauro criatura marcada desde o berço, estava escrito que iria subir muiiiitíssimo na asa da compostura, por cima dos casebres da aldeia e do palácio dos ricos, e que teria de tirar um curso que lhe desse para governar toda a gente. Leis, decidiu o padre local,

\section{"ESTA CRIANÇA VAI PARA LEIS."}

$\mathrm{O}$ regedor, muito dado à farda e às marchas, disse que na espada é que estava o mando e a justiça, e nessa conformidade o militar valia por 2 (dois): pelo guerreiro e pelo doutor de leis. [...] No modo de ver do regedor, o pequeno daria um valente general de sete estrelas - ou mais.

\footnotetext{
${ }^{193}$ CALVINO, Ítalo. Fábulas italianas. São Paulo: Companhia das Letras, 2005, p. 35.

${ }^{194}$ PIRES, José Cardoso. Dinossauro Excelentíssimo, cit., p. 47.

195 Ibid., p. 127.

${ }^{196}$ PIRES, José Cardoso. Dinossauro Excelentíssimo, cit., p. 31.
} 
[...] Dona Madrinha da criança, que era rica e muito solteira [...] Ouviu falar em espadas, em guerreiros, e nem esperou por mais nada; abriu os braços de contentamento pronunciando estas palavras à boca do berço:

“QUE PERFEITO MISSIONÁRIO!"197

É oportuno reafirmar o caráter retórico da fábula: dá-se um exemplo para demonstrar certo propósito através de uma afirmação moral. Logo, entendemos que, em geral, a moralidade funciona como motivo para a apresentação de um discurso argumentativo, cuja finalidade é trazer à reflexão alguns temas que permeiam a narrativa. Em Dinossauro Excelentíssimo, a moral, além disso, encerra uma vertente pedagógica que pode ser observada no emprego de aforismos. Essa prática é comum no gênero fábula e, no texto em questão, é pretexto para denunciar o estado de opressão vivenciado pela sociedade portuguesa durante a ditadura salazarista e para refletir sobre as consequências dele advindas. A moralidade desta fábula está diluída ao longo da narrativa, assim como nesta sentença: "Deus concedeu-nos a graça de nos querer pobres."198

O Reino dos Mexilhões é, portanto, uma alusão a Portugal, um espaço onde circulam todos os discursos: o do Imperador, que é o da "ordem"; o do povo, através de provérbios; o dos mexilhões descontentes, por meio da linguagem cifrada; e o do narrador, cuja função é contar estórias sobre a História e torná-las memória: "toma nota, Ritinha"199.

Essa inspiração histórica associada à inclinação para a fábula - temática recorrente na obra cardosiana - representa as linhas-mestras com as quais esse texto é tecido. A realidade histórica, que se transfigura em conteúdo literário, tem como base a figura de um ditador, o olhar a memória da ditadura, a remissão a um tempo de terror e desassossego. Todos esses eixos temáticos são também desenvolvidos em outras narrativas de José Cardoso Pires, como em Balada da Praia dos Cães, ou no texto teatral Corpo-delito na sala de espelhos; entendemos que em Dinossauro Excelentíssimo a ditadura exercida no Reino dos Mexilhões

\footnotetext{
197 Ibid., p. 19-21.

198 Ibid., p. 49.

${ }^{199}$ PIRES, José Cardoso. Dinossauro Excelentíssimo, cit., p. 31.
} 
revela uma relação degradante entre o homem e o poder absoluto ${ }^{200}$. As relações de poder estabelecidas nesse Reino serão abordadas nos capítulos seguintes, que analisam a censura da palavra e o poder da imagem, respectivamente.

${ }^{200}$ GARCÍA, Maria Jesús Fernández. La novela del ditador Salazar: Dinossauro Excelentíssimo de José Cardoso Pires. Anuário de Estudos Filológicos. Mérida, ESP: Universidad de Extremadura, ano XIII, 2000, p. 125. 


\section{O REINO DOS MEXILHÕES}

[...] interrogo-me onde está o ponto de vista do autor? É uma pergunta que me intriga. Interrogo-me e não encontro respostas. Talvez o ponto de vista do narrador coincida com o leitor, seja um ponto de vista aberto, seja [...] um ponto de vista que interroga. ${ }^{201}$

Antonio Tabucchi

Portugal é um país habitado por criaturas carregadas de Histórias, as quais Cardoso Pires compara a um molusco, ao mexilhão: “cativo, pobre e obscuro, já sem água, todo crespo, que vive a contracorrente no anonimato do rochedo" ${ }^{202}$. Os mexilhões formigam à margem da memória; dizem que eles carregam consigo a pele de árabe, o amargor de especiarias, o olhar de cartógrafo, a sagacidade não tenaz do judeu, mas a paciência obstinada de ser português. É neste país que o português se dobra ao peso da História, pois "Mal nasce deixa de ser criança: fica logo com oito séculos." ${ }^{203}$ Segundo Cardoso Pires,

[...] pode até notar-se que escoa um brilho de humor por sob a casca, um riso cruel, de si para si, que lhe serve de distância para resistir e que herdou dos mais heróicos, como Fernão Mendes à cabeça, seu avô de tempestades. Isto porque, lá de quando em quando, abre muito em segredo a casca empedernida e, então sim, vê-se-lhe uma cicatriz mordaz que é o tal humor. Depois fecha-se outra vez no escuro, no olvidado. ${ }^{204}$

Esses mexilhões anônimos, pessoas comuns que constroem a história do país, habitam há muito tempo uma faixa de litoral, onde cravaram as unhas e os dentes “com amor, com desespero ou lá o que é. Quer isto dizer que está preso à Europa pela ponta, pelo que sobra dela para não se deixar devolver aos oceanos que descobriu com muita honra" 205 . É sobre a história desses mexilhões que Cardoso Pires nos fala na fábula Dinossauro Excelentíssimo, precisamente sobre um momento em que esses mexilhões experimentam a fome, a opressão e o medo, depois de seu Reino ser tomado pelo Imperador Dinossauro.

\footnotetext{
${ }^{201}$ PORTELA, Arthur. Cardoso Pires por Cardoso Pires, 1991, p. 13.

${ }^{202}$ PIRES, José Cardoso. Visita à oficina: o texto e o pré-texto, cit., p. 21.

${ }^{203}$ PIRES, José Cardoso. Lá vai o português. In:___. E agora, José?, cit., p. 21.

${ }^{204}$ Ibid., p. 22.

${ }^{205}$ Ibid., p. 21.
} 
Antes de ser escrito, um texto já é, em si, uma leitura, a interpretação de um fato que se quer tema. Nesse sentido, um texto é múltiplo, fértil, e solicita que lhe coloquem indagações, que o debatam, que o reflitam, que com ele dialoguem. $\mathrm{Na}$ fábula em análise, é possível observar o diálogo existente entre a escrita de Cardoso Pires e a versão dos fatos sob a ótica do discurso ditatorial de Salazar, urdido nas entrelinhas de suas tramas, como num entrelaçar da ficção e da História.

O discurso ficcional é um espaço onde se pode estilhaçar o discurso da história, e as versões que podem ser contadas a partir de uma visão plural do fato resgatado pela História oficial. No enredo da fábula em estudo, é possível vermos emergir acontecimentos ligados à ditadura do Estado Novo português. Nessa narrativa, Cardoso Pires lê e denuncia o que o governo pretende escamotear, perseguindo os rastros que se configuram nas ações do Dinossauro e as pegadas dele (Dinossauro / Salazar) em seu processo obsessivo, caracterizado pela busca da ORDEM no Reino dos Mexilhões. Esse Reino, uma alegoria do estado ditatorial, está delineado conforme o ponto de vista de um mexilhão (o contador da história) que alerta os mais jovens sobre o modo como viviam os mexilhões, num espaço sombrio, em que "A fome vinha e varria tudo para o oceano" 206.

A época descrita pelo narrador revela um país segregado, em que os mexilhões Dê-erres, filhos de camponeses abastados, educados segundo a sebenta dos Mestres, como fora o Imperador, davam as cartas; eles invadiram o reino para colocar ordem através de seu saber e teceram uma rede de poder que lhes permitia mandar em outros mexilhões, naqueles que ficaram à beira do oceano:

Tinham cercado primeiro a capital, mascarados de juízes, mangas-de-alpaca, meninos de coro e curadores dos pobres; infiltraram-se nas secretarias, ocuparam pontos estratégicos - à duas por três, a eles, a eles, que é uma pressa, caíram em cima dos mexilhões, brandindo os seus canudos de bacharéis:

\section{'IN HOC SIGNO VINCES!}

\section{IN HOC SIGNO VINCES'}

Apanhados de costas, os da beira-mar renderam-se sem discussão, tanto mais que não compreendiam a língua dos invasores. [...]. Discursos e contra-discursos, discursos por uma pá velha como só os dê-erres sabem fazer: com excelência para esquerda e excelência para a direita, e não sei se me faço compreender. E assim é que se enxofra.

\footnotetext{
${ }^{206}$ PIRES, José Cardoso. Dinossauro Excelentíssimo, cit., p. 41.
} 
'TENHO DITO.' 207

Embora ferozes em suas decisões, considerando-se o poder que detinham, os Dê-erres não conseguiam acabar com a desordem e com a fome que se alastravam pelo Reino. Para conter a situação de desequilíbrio nas finanças do Reino, eles criam o jogo da lotaria a fim de evitar a revolta dos mexilhões: "jogava este o que não tinha, o outro o que se lhe acabava; jogava o coxo e o enforcado, e até o cego [...]. Esta forma de provocar fortuna evitava as guerras que há sempre por trás do vil dinheiro, era a mais sábia." ${ }^{208}$ Por esse motivo, os Dê-erres foram às montanhas buscar o Imperador, que deveria pôr fim à desordem estabelecida no Reino dos Mexilhões: o Imperador vinha "magro e iluminado de tanto estudar, mas vestido de mestre. Porque o era." 209 Desse modo, o Imperador, que fora preparado pela elite rural, veio para o Reino com a intenção de colocá-lo em ordem, e o fez a seu modo:

Sua alteza, o camponês mestre doutor, foi recebido na cidade com milmilhares de banderinhas e fff-foguetes a assoprar [...]. A seguir, coisa e tal, navegou em pensamento de onda larga e a grande profundidade, fez duas abordagens na metáfora, avançou pelos horizontes do amanhã - enfim, falou, disse coisas. E tal. Para terminar, levantou os braços à divina Providência:

\section{'DEUS CONCEDEU-NOS A GRAÇA}

DE NOS QUERER POBRES.'

Apoiado! pelos dê-erres, deixou a tribuna num rastro de música e de aplausos. ${ }^{210}$

E o reino ficou ainda mais sombrio, pois o Imperador se esmerava em fazer uso de sua especialidade, a "palavra". Ele passou a orientar os morcegos a caçarem as palavras perigosas, comparando seus significados ao veneno das serpentes. Desse modo, era necessário limpá-las o quanto antes, para que não contaminassem o Reino nem caíssem nas mãos dos pedintes voadores mexilhões revoltosos -, que poderiam destruir o reino tão bem organizado por esse Imperador-Dinossauro. Enfim, o Reino foi estruturado pelo saber e pela autoridade do Imperador, que o fechara a Sete Chaves: um reino vigiado em que "Sua Alteza tentava convencer a todos através de seus discursos" elaborados com

\footnotetext{
${ }^{207}$ PIRES, José Cardoso. Dinossauro Excelentíssimo, cit., p. 43-44.

${ }^{208}$ Ibid., p. 47.

${ }^{209}$ Ibid., p. 48.

${ }^{210}$ Ibid., p. 48-49.
} 
"frase gótica para o Além, mais ou menos para o ponto onde fica a História",211. Isto é, seriam discursos não para os camponeses que estavam a ouvi-lo, mas para ecoar na História.

Nesse Reino, onde não há rei, mas sim um Imperador-Dinossauro, os atos arbitrários contra os mexilhões são constantes; dentre eles, chamam a atenção aqueles derivados da força agregadora da palavra (semelhantes ao desejo da ditadura salazarista de homogeneizar as ideias), como a alteração da sintaxe por meio de censores, ou o uso de palavras-objeto a serem trabalhadas na fábula. Dessa forma, assim como Salazar utilizou o poder coercivo da palavra para criar versões dos fatos, o contador de história de Dinossauro Excelentíssimo também narra acontecimentos para que eles não fiquem silenciados nem caiam no esquecimento. Essa é uma estratégia de inscrição da História na fábula, na qual o autor não coloca um ponto final. O narrador diz que esta é uma versão - "Supõese, está vagamente escrito" ${ }^{212}$ - sobre a estória de um reino, de um ditador, de um tempo perdido na memória, reino que um dia já foi Império. Diante de seus feitos - "boa sorte, desejava-lhe a História"213 -, importa ressaltar que nesta fábula a História várias vezes é personificada, é uma entidade que recebe e guarda os fatos históricos.

\subsection{0 enigma}

No plano da recriação dos fatos históricos, Cardoso Pires sugere que o jogo consiste em "ultrapassar o processo normativo de uma sequência unívoca dos acontecimentos" ${ }^{214}$, ou seja, em desdobrar prováveis versões, ou criar outras, sobre determinados acontecimentos. Os fatos algumas vezes tornam-se "Enigmas, coisas da História que tem destes passos sem rastros para despistar os curiosos". 215 Para desenvolver esse procedimento, é necessário que o escritor interrogue o seu tempo, que se coloque à margem das vozes unívocas, que seja capaz de se deslocar em tempo, espaço e memória, correr tintas e desprezar o

\footnotetext{
${ }^{211}$ PIRES, José Cardoso. Dinossauro Excelentíssimo, cit., p. 84.

${ }^{212}$ Ibid., p. 17.

${ }^{213}$ Ibid., p. 41.

${ }^{214}$ PIRES, José Cardoso. Visita à oficina: o texto e o pré-texto, cit., p. 144.

${ }^{215}$ PIRES, José Cardoso. Dinossauro Excelentíssimo, cit., p. 25.
} 
ponto final, meter-se por baixo de "toda folha de prosa - e sempre com o fito de penetrar nas zonas ambíguas onde determinadas premissas aleatórias podem actuar como reagentes capazes de desfazer a ferrugem ou os dourados que recobrem a essência do real" ${ }^{216}$.

José Cardoso Pires, em suas narrativas, resgata a História que está sob a poeira da memória, ou nas "rugas dos pergaminhos" 217 . Ao ler a fábula, através de uma leitura vertical, percebemos que o leitor mergulha em uma segunda "fábula", que se entrelaça à primeira, pois, como diz Piglia, um relato visível esconde "um relato secreto, narrado de um modo elíptico e fragmentário. O efeito de surpresa se produz quando o final da história secreta aparece na superfície"218. Desse modo, a fábula em análise disserta sobre o modo como o poder onipresente entretece sua rede em ambas as narrativas, para relatar a vida de um ditador e a configuração do Reino dos Mexilhões, movido pelo medo e pelo silêncio imposto por esse ditador.

No Reino dos Mexilhões, encontramos relatos secretos configurados a partir da construção significativa dos diversos temas apresentados pelo narrador. Percebemos um olhar crítico do contador de histórias, que se expande numa visão panorâmica, recuando no tempo, contudo ao mesmo tempo esse olhar é fragmentado, direcionado para as pequenas histórias que compõem a narrativa, como certos relatos que ficam escondidos nas rugas da História, como enigmas dos fatos.

Algumas vezes, em sua obra, Cardoso Pires simula fontes para resgatar fatos históricos, memórias culturais e ideológicas. Em Alexandra Alfa (1987), o autor traz para a narrativa várias vozes culturais através de gravuras, diários, fotos, murais, filmes, romances, poemas, campanhas publicitárias, fitas-cassete, tatuagens, grafites, manequins, revistas em quadrinhos. Tudo isso são retalhos culturais que, reunidos pelo leitor, constroem a imagem híbrida do romance. Nesse sentido, as figuras híbridas e silenciosas, assim concebidas, dissertam sobre questões sociopolíticas e têm, na narrativa, a função de abrir os olhos do leitor, a

\footnotetext{
${ }^{216}$ PIRES, José Cardoso. Visita à oficina: o texto e o pré-texto, cit., p. 144.

${ }^{217}$ PIRES, José Cardoso. Dinossauro Excelentíssimo, cit., p. 51.

${ }^{218}$ PIGLIA, Ricardo. Formas breves. Trad. José Marcos M. de Macedo. São Paulo: Companhia das Letras, 2004, p. 90.
} 
fim de levá-lo a interpretar os fragmentos heterogêneos com os quais são tecidas as suas imagens.

Semelhante método é percebido em Dinossauro Excelentíssimo. Embora o narrador não possua um espólio de documentos escritos (não há fontes autorizadas ou relatos históricos) da história oficial, percebemos que a fábula está construída a partir de micro-histórias, que não deixam de conter uma pluralidade de vozes. Relacionada aos fatos históricos de um país alusivamente representado, essa transfiguração oral se apoia ainda nas histórias condensadas dos ditados populares e em pequenos enigmas culturais ideológicos, os quais, reunidos, tecem a fábula de um Dinossauro e de mexilhões. Portanto, entendemos que o contador de histórias, ao narrar sua história a Ritinha, sobrepõe os temas para depois desdobrálos e revelá-los em pequenos textos. Lançando mão desse artifício, o narrador entrelaça habilmente discursos sobrepostos conforme uma montagem de pequenos fragmentos, que serão cortados e colados, criando um tecido em que a palavra escrita e a palavra oral dialogam em busca de significados novos. Dessa forma, toda a trama é tecida com fios esgarçados de outras histórias, além de fatos históricos, textos de longínquas fontes que se entrelaçam aos da fábula.

Deus criou o som, o homem fez a palavra. Depois, tal como a fez, aprendeu a destruí-la ou a corrompê-la e senão vejamos. Temos esta fita gravada, repara. Agora, cortando um pedaço escolhido - assim - é colando-o noutro ponto - acolá podemos, é relativamente fácil, transformar a verdade da voz que aqui está. Apagar, desdizer a voz, até. Confundi-la. Montagem, chama-se a esta operação que, como vês, é facílima. Mas há processos menos simples e muito mais eficazes. Ritinha. Se há. ${ }^{219}$

Esse método é referido pelo narrador da fábula na tentativa de explicar à sua ouvinte, a personagem Ritinha, o procedimento para criar uma "montagem". Podemos, em nível hipotético, dizer que Cardoso Pires, tendo buscado fontes históricas - como já fizera em narrativas anteriores -, diz-nos como compôs esta narrativa. Observamos que ele parte do som, que foi criado por Deus, para depois referir-se à palavra, que foi criada pelo homem; indo um pouco além em nossa análise, e considerando-se que a palavra é uma invenção humana e, portanto, cultural, ela é passível de manipulação. No fragmento acima, o contador tem como fonte uma fita gravada anonimamente, o que reforça o caráter da narrativa

\footnotetext{
${ }^{219}$ PIRES, José Cardoso. Dinossauro Excelentíssimo, cit., p. 54.
} 
popular, de lendas, fábulas e ditados populares que são passados informalmente às gerações futuras, o que justifica as micro-histórias atemporais, que, contextualizadas, ganham outro sentido, ou seja, transformam a verdade até confundi-la.

Abdala Junior, em ensaio, conclui que, na obra cardosiana, "o projétil da estória que atinge a personagem [...]. Atinge também a história que lhe serve de referência" ${ }^{220}$. Diante dessa tensão, a de reescrever a história até então oculta na estória, os narradores cardosianos buscam também, em outras narrativas, por exemplo, desvendá-la "no sopro de nuvem que é a lagoa [...] secreta e indiferente [...] lá está ela a respirar"221; no fundo de uma gaveta onde provavelmente estará a "chave do segredo" "222, ou nas "implacáveis manchas azul da prússia [...] que falam como gente quando acusam"223. Na fábula Dinossauro Excelentíssimo, o contador de estórias procura seguir o cheiro e a voz de um ditador, desvendar os enigmas que permeiam o enredo entremeado pelas interseções históricas e culturais, intertextos típicos da sabedoria popular. Segundo Maria Lúcia Lepecki, Cardoso Pires busca nos "provérbios que cita ipsi verbis ou modificados [...] enunciados [...] feitos no absoluto respeito da atmosfera e até do ritmo do ditado popular"224.

Nesse sentido, em vários fragmentos do texto de Dinossauro Excelentíssimo, torna-se perceptível essa pesquisa porque há vários eventos que são metafórica e metonimicamente retomados por Cardoso Pires, como se as fontes históricas referidas norteassem sua escrita. Mas não podemos nos esquecer de que o objetivo da narrativa é outro: embora o autor tenha feito um levantamento documental do regime ditatorial de Salazar, sua intenção é interpretar os fatos sob a ótica da ficção; ou seja, o narrador busca relatar aspectos que estariam ausentes no discurso da História oficial.

É claro que Cardoso Pires, em suas obras, retoma fatos históricos fazendo outras leituras, mostrando outras dimensões que o fato documentado não

\footnotetext{
${ }^{220}$ ABDALA JUNIOR, Benjamin. Os cravos de abril e os encontros da história, cit., p. 48-49.

${ }^{221}$ PIRES, José Cardoso. O Delfim, cit., p. 36.

222 PIRES, José Cardoso. Balada da Praia dos Cães: dissertação sobre um crime. Rio de Janeiro: Civilização Brasileira, 1983, p. 22.

${ }^{223}$ Loc. cit.

224 LEPECKI, Maria Lúcia. Delfins, corvos e dinossauros: interseções discursivas em José Cardoso Pires. SCRIPTA, Belo Horizonte, v. 7, n. 14, 1 sem. 2004, p. 205.
} 
registrou. Sabe-se que a censura atuou energicamente nessa época, criando, com seus cortes, um país "virtual", de modo que o que se lia sobre Portugal, durante a vigência do regime de Salazar, dava ao povo a ideia de que tudo estava seguindo um curso normal e ordenado, quando, na verdade, os fatos estavam sendo escamoteados. Criou-se uma ideia de "limpeza" a "golpe de faca" em função do projeto elaborado por Salazar, expresso por palavras lavradas a ferro e fogo. Quanto aos censores, estes faziam seu papel, pois limpavam todas as "sujeiras" de uma sociedade refém da ditadura salazarista.

\subsubsection{Douktor Dinossaurus}

Na obra cardosiana, a História não é só pretexto para questionar ou reler o passado, pois o autor busca também revelar e analisar o comportamento humano. Observamos que Cardoso Pires também passa a focalizar a "vida dos anônimos, identificar os sintomas de uma época, sociedade ou civilização nos detalhes ínfimos da vida ordinária, explicar a superfície pelas camadas subterrâneas e reconstituir mundos a partir de seus vestígios”225. Através das ações de seus personagens, ele é capaz de dissertar sobre temas que afligem o ser humano, ou mesmo levantar questões de caráter universal. Isso ocorre pois algumas experiências podem ser vivenciadas também por outros personagens envolvendo contexto semelhante, como o da ditadura, além de todas as ramificações que dela possam emergir, como, por exemplo, a censura e a imagem do poder contidas na figura do ditador. Portanto, as questões dos insubmissos que se opõem ao regime, os mecanismos de censura, o discurso do poder, tudo isso pode tanto ser relatado pela história oficial como vir a ser tema de enredos fictícios.

As narrativas de Cardoso Pires, além de tirarem do esquecimento fatos cruciais da história do Estado Novo Português, procuram também interpretá-los, de modo que os enredos históricos se tornem peças fundamentais na transfiguração para uma nova narrativa. Mas Cardoso Pires pondera: "o movimento da história pressupõe ascensão e queda [...] É um processo, uma

${ }^{225}$ RANCIÉRE, Jacques. Das artes mecânicas e da promoção estética e científica dos anônimos. In: ___ A partilha do sensivel: estética e política. Trad. Mônica Costa Netto. São Paulo: EXO / Ed. 34, 2005, p. 49. 
tendência. Ou se transforma, ou se aniquila."226 Logo, em Dinossauro Excelentíssimo, o questionar de Cardoso Pires procura desmascarar os fatos encobertos pelo discurso oficial e, para realizar tal ação, o autor se afasta do "discurso centralizado", buscando a margem para encontrar a história escamoteada.

Como já referimos antes, Cardoso Pires tende a dissertar sobre vários assuntos a partir das ações de seus personagens. O narrador relata como é importante para o Imperador ultrapassar seu tempo, pois ele percebe uma maneira de se perpetuar na história através de seus discursos: "Queria agarrar o eco dele próprio, o seu prolooongamento ao looongo da História"227, de modo que "voltouse acto contínuo para a História"228. Entendemos que esses exemplos estão cobertos de ironia. Para o autor, a História tende a imortalizar os grandes nomes, e cabe à ficção ler quaisquer fatos, notórios ou não, que podem ser escritos em frases góticas. Por isso, algumas vezes, o narrador questiona a visão oficial da História, que apresenta uma versão unilateral, com o recurso da interlocução direta com o leitor, a fim de chamar sua atenção e levá-lo a ver que é possível haver mais de uma versão dos fatos. Para atingir esses objetivos, o narrador enfatiza pequenas frases que se voltam para a narrativa, a fim de que o leitor se conscientize e reflita sobre o tema discorrido ou sobre os fatos que estão sendo narrados, através de expressões como "Mas como diz o outro"229 "só visto",230 " "E aqui para nós" 231 .

Além disso, observamos que o narrador, ironicamente, põe em dúvida alguns fatos vividos pelos personagens. Entendemos que, indiretamente, o autor questiona a "oficialidade" do discurso histórico do Estado. Por exemplo, no episódio em que o Imperador dispensa os "mágicos" que o ajudaram a construir a câmara de torturar palavras, o narrador ironicamente diz que o Mestre "seguidamente pagou aos mágicos os salários prometidos e empurrou-os para o 'OLHO DA RUA' (ou mandou-os matar, na opinião de alguns historiadores)" 232.

\footnotetext{
${ }^{226}$ ABDALA JUNIOR, Benjamin. Os cravos de abril e os encontros da História, cit., p. 49.

${ }^{227}$ PIRES, José Cardoso. Dinossauro Excelentíssimo, cit., p. 106.

${ }^{228}$ Ibid., p. 84.

${ }^{229}$ Ibid., p. 24.

${ }^{230}$ Ibid., p. 31.

231 Ibid., p. 51.

${ }^{232}$ Ibid., p. 55-56.
} 
Nessas palavras, percebemos que os questionamentos se concentram na vida privada do futuro Imperador, e não em sua vida pública, como é registrada nos compêndios das escolas. Além disso, o posicionamento do narrador oferece uma visão descentralizada dos grandes atores da História oficial. Após a apresentação de questões e o levantamento de hipóteses, o narrador deixa a cargo da História o peso de não saber (ou não poder) responder a elas, focalizando-as como se fossem enigmas a serem desvelados, porque a própria História não teria dado ao narrador elementos suficientes para responder às questões suscitadas. Observamos que certas interrogações do narrador, embora possam parecer de pequena importância, e por isso tenham sido desprezadas pelo discurso historiográfico, mostram-se relevantes, são o "detalhe" que o contador pretende revelar, para além do tom irônico com o qual trata do assunto.

As marcas que indicam essa subjetividade são importantes para o contador, que recolhe material de múltiplas fontes. $\mathrm{Na}$ fábula, verificamos que elas são recorrentes: "segundo a lenda, teria sorrido tristemente, aconchegando a criança contra o peito e pensando se calhar em como era frágil o seu filho" ${ }^{233}$. Outro exemplo ocorre ao fornecer informações relativas à construção da imagem da época da ditadura, quando não permite que a própria fonte ou personagem central se pronuncie, pois "do modo de ver do regedor, o pequeno daria um valente general de sete estrelas - ou mais" ${ }^{, 234}$.

Desse modo, em Dinossauro Excelentíssimo, a estória vai-se constituindo em torno do Imperador. É através da narração da estória do Imperador que vemos outra versão da História, sob o ponto de vista do Mexilhão - criatura que, na fábula, se caracteriza pela resistência às adversidades, porque, embora viva em silêncio e ao pé da rocha, luta, debatendo-se contra o mar que o lixa constantemente.

Há, ainda, a preocupação dos personagens que exercem o poder de registrar certos fatos históricos e, ao mesmo tempo, refletir sobre a forma como são interpretados. Em outras palavras, remetemos à inserção do narrador ao interpretar tais fatos por meio do questionamento irônico sobre a própria história, interrogando sempre o espaço e a perspectiva de onde se vê o acontecimento:

\footnotetext{
${ }^{233}$ PIRES, José Cardoso. Dinossauro Excelentíssimo, cit., p. 25-26.

${ }^{234}$ Ibid., p. 19.
} 
Alguém lhe chamou Dinossauro - ficou. Na história, como Dinossauro Primeiro, Imperador Mestre; na memória dos mexilhões como Doutor Dinossauro simplesmente. Ou como Douktor Dinossaurus, que é para soar mais áspero e mais crepuscular. Mas gótico. Sempre diz melhor com ele. ${ }^{235}$

Para os opressores, ele é quem detém o poder, "Dinossauro Primeiro"; já para os mexilhões "analfabetos", é o "Doutor Dinossauro", aquele que detém o saber; por fim, para o narrador, é nomeado ironicamente, ou goticamente, de "Douktor Dinossaurus".

Em outro episódio, observamos que o narrador expõe a questão do limite entre o real e o fingido, porque essa encenação é explorada na fábula para articular "as memórias vividas". Talvez aqui o autor esteja a provocar questões que envolvam o limite entre a construção do discurso histórico e do fictício. $\mathrm{O}$ fragmento seguinte continua a examinar o assunto:

\section{GEROU-SE A CONFUSÃO}

Porque os especialistas trabalhavam, como é lógico, para o novo imperador, e a páginas tantas havia um comércio sombrio entre o Reino (ou Torre) do Ermitão e o Reino a Sério, o real. Começavam mesmo a perguntar-se onde começava um e onde acabava o outro. ${ }^{236}$

A referida situação ocorre porque, após a morte e a ressurreição do Dinossauro, cria-se na fábula uma dupla "realidade": a real e a virtual. Entendemos que o autor joga com a ideia de História e estória, pois três indícios nos possibilitam esta interpretação: primeiro, o significado da palavra "página", que apresenta duplo sentido, ou seja, página de livro, mas também, por analogia, página da História; segundo, quando delimita dois espaços - a "torre", onde acontecem os fatos "fíctícios", e o espaço "real", que seria o próprio Reino; e o terceiro indício relaciona-se ao comércio sombrio entre o Reino do Ermitão e o Reino a Sério.

Retomando o que já dissemos, há na escrita cardosiana a ideia de que os acontecimentos históricos são envolvidos por "fumos", lugares sombrios. Essa negociação entre história e estória se tece com fios quase imperceptíveis ao olhar.

\footnotetext{
${ }^{235}$ PIRES, José Cardoso. Dinossauro Excelentíssimo, cit., p. 100.

${ }^{236}$ Ibid., p. 142-143.
} 
Parece não haver limite definido entre as duas realidades, ou, como quer o autor: "Vida dupla [...] vida, diziam, de saber e ocultar"237.

A leitura sobre o cenário histórico se estende a outros temas, voltados para uma preocupação em fixar fatos na história, como a que têm os Dê-erres em registrar suas ações para outras gerações, o desejo de fazer parte da história:

Manter a figura imperial segundo a vontade da nação parecia-lhes um dever que nem se discutia, um dever, diziam, sacrossanto. Mais: inexpugnável aos olhos das gerações que haviam de vir e dos sublimes destinos do Reino. Um dever-etecétera, uma missão igualmente etecétera. Maior clareza não seria possível. ${ }^{238}$

Ao fim de muito reunirem para a estátua, convenceram-se de que se calhar eram conselheiros a sério e que estavam a cumprir uma grande missão

HISTÓRICA

- evidentemente. ${ }^{239}$

Portanto, no Reino dos Mexilhões, espaço em que Cardoso Pires está imerso, percebemos as escritas paralelas, ou as entrelinhas que revelam a nova versão do estado ditatorial que Salazar impôs a Portugal. Mas, perguntamos quais fatos históricos podem ser entrevistos na fábula em análise.

\subsection{A história}

martelar constantemente as suas ideias, despi-las da sua rigidez, dar-lhes vida e calor, comunicá-las à multidão: Que o ditador fale ao povo.

António Ferro

Pondo fim ao Estado Novo português, a Revolução dos Cravos foi celebrada e comemorada com grande euforia, pois, conforme afirmam Phil Mailer e Maurice Brinton, fazia "quarenta e oito anos não tinha havido manifestações de alegria em Portugal" ${ }^{, 40}$. No entanto, esse momento foi intuído em algumas obras "pretéritas", "silenciosas", que circulavam à época do Estado Novo. E esse desejo é projetado no Dinossauro Excelentíssimo, pois a narrativa revela o contexto sombrio que

\footnotetext{
${ }^{237}$ PIRES, José Cardoso. Dinossauro Excelentíssimo, cit., p. 141.

${ }^{238}$ Ibid., p. 101.

${ }^{239}$ Ibid., p. 134.

${ }^{240}$ MAILER, Phil; BRINTON, Maurice. Portugal: a revolução impossível? Porto: Afrontamento, 1978, p. 37.
} 
envolve o Estado Novo português. Cabe ao leitor uma margem em que possa intuir um futuro livre da ditadura e da censura - enfim, como o narrador diz à sua filha: "fartamos-nos de falar de mortos, de velhos, de mistérios, quando afinal temos tanto para viver. Não é?"241

Os regimes totalitários ${ }^{242}$ irromperam na Europa durante os anos trinta do século XX: o fascismo na Itália, com Benito Mussolini, e o nazismo na Alemanha, com Adolf Hitler. Após a ascensão do nazismo, outros países adotaram ideologias semelhantes, embora com características próprias; dentre estas, ressaltamos o franquismo na Espanha, sustentado por Francisco Franco, e o salazarismo em Portugal, representado por Antonio Oliveira Salazar. Vejamos o que diz Eric Hobsbawm ao analisar esse período:

O fascismo italiano sozinho não exerceu muita atração internacional. [...] Sem o triunfo de Hitler na Alemanha no início de 1933, o fascismo não teria se tornado um movimento geral. [...] Além disso, sem a posição internacional da Alemanha como potência mundial bem sucedida e em ascensão, o fascismo não teria tido impacto sério fora da Europa, nem teriam os governantes reacionários não fascistas se dado o trabalho de posar de simpatizantes fascistas, como quando Salazar de Portugal alegou, em 1940, que ele e Hitler estavam "ligados pela mesma ideologia". 243

O fascismo português passou por algumas adaptações, embora trilhasse o modelo que Benito Mussolini implantou na Itália. Salazar deu-lhe caracterização própria, porque, "apesar dos instrumentos fascistas, como a lei de trabalho inspirada em Mussolini, que bania as greves e a existência de uma impiedosa polícia secreta, o Estado Novo era essencialmente um regime católico autoritário" 244 , instaurado há várias décadas.

Essa particularidade do fascismo português é ironicamente tratada na fábula Dinossauro Excelentíssimo, pois o narrador relata: "Por adivinhar mistério naquele pequenino ser é que o Regedor insistia em lhe futurar um ofício que servisse ao divino e ao profano. Cruz e bandeira sempre marcharam juntas ao

\footnotetext{
${ }^{241}$ PIRES, José Cardoso. Dinossauro Excelentíssimo, cit., p. 148.

${ }^{242}$ Totalitarismo: conceito "inicialmente inventado como uma descrição ou autodescrição do fascismo italiano, era aplicado quase só a esse regime" (HOBSBAWM, Eric. Era dos extremos: O breve século XX: 1914-1991. São Paulo: Companhia das Letras, 1995, p. 116).

${ }^{243}$ DELZELL, 1970, apud HOBSBAWM, Eric. Era dos extremos, cit., p. 119-120.

${ }^{244}$ MAXWELL, Kenneth. A construção da democracia em Portugal. Lisboa: Presença, 1999, p. 31.
} 
longo da História"245 - ou seja, Igreja e Estado caminhando juntos. De acordo com Hobsbawm, ainda que o fascismo tenha se oposto à Igreja Católica Romana, uniu-se a ela na criação do "Estado corporativista", principalmente em países católicos, como Portugal, onde o regime foi denominado de "clerical-fascista". O historiador diz que a relação que havia entre a Igreja e o fascismo pode ser explicada pelo profundo ódio comum pelo Iluminismo do século XVIII, pela Revolução Francesa e por tudo o que, na opinião do teórico, dela derivava, como: democracia, liberalismo e, claro, mais marcadamente, o "comunismo ateu" 246.

Os fatos sociopolíticos ocorridos em Portugal que levaram ao poder António de Oliveira Salazar (1889-1970) tiveram início em 1910, com a morte de D. Carlos, rei de Portugal, e de seu filho D. Luis Felipe. Após a morte do rei, os militares não aceitaram seu sucessor, D. Manuel, seguindo-se daí um golpe militar para em seguida se proclamar a República Portuguesa, tirando a monarquia do poder, em outubro de 1910. A intenção dessa proclamação seria promover em Portugal um avanço sociopolítico em relação aos demais países da Europa, independentes e prósperos. Portugal se encontrava em pleno descompasso, com questões a serem resolvidas nas esferas sociais, econômicas, políticas e culturais. Dentre esses problemas, destacava-se a economia precária, baseada ainda na dependência da agricultura, e, culturalmente, a crença na volta de D. Sebastião. Eduardo Lourenço esclarece que o sebastianismo é uma "forma popular dessa crença de uma vinda do Rei vencido" 247.

Em razão de crise militar e econômica, sucedeu-se em 28 de maio de 1926 um novo golpe de estado, liderado pelo General Gomes da Costa. Convocadas eleições diretas em 1928, Óscar Carmona foi eleito e assumiu o poder como chefe de Estado, indicando para a pasta de finanças António de Oliveira Salazar, acreditando que o jovem economista estaria capacitado para sanar a crise

\footnotetext{
${ }^{245}$ PIRES, José Cardoso. Dinossauro Excelentíssimo, cit., p. 20.

${ }^{246}$ HOBSBAWM, Eric. Era dos extremos, cit., p. 118.

${ }^{247}$ LOURENÇO, Eduardo. Portugal como destino. Dramaturgia cultural portuguesa. In: Mitologia da saudade: seguido de Portugal como destino. São Paulo: Companhia das Letras, 1999, p. 97. Conforme notas desse texto, Alcácer Quibir foi "uma batalha travada no Marrocos (1578) entre D. Sebastião, rei de Portugal, e o rei de Marrocos. O maior desastre militar e político da história portuguesa. D. Sebastião, jovem rei sem herdeiro, morre nesse combate. Dois anos depois (1580) Portugal perdia sua independência. O sebastianismo é a crença messiânica no regresso de D. Sebastião: mito ao mesmo tempo popular e literário, impregna o inconsciente português até hoje" (Loc. cit.).
} 
financeira do país ${ }^{248}$. Como ministro de estado, Salazar distinguiu-se por equilibrar o orçamento nacional e estabilizar as finanças. Por esse feito, Antonio de Oliveira Salazar ascendeu ao poder e implantou o Estado Novo de orientação fascista em 1933, sendo esse ano o marco do período que passava a ser chamado de salazarismo. E só depois de quarenta e dois anos de governo, Salazar, por motivo de doença, foi substituído por Marcelo Caetano ${ }^{249}$. Ana Silvia Scott explica:

Na perspectiva da propaganda de Salazar, o Estado Novo não era totalitário e sim um estado de direito, já que tinha uma Constituição aprovada por plebiscito popular e se pautava por dois valores fundamentais: Deus e Pátria. [...]. O Salazarismo no comando do Estado justificava-se como o defensor da sociedade. Suas intervenções no domínio da economia seriam no sentido de 'garantir uma melhor distribuição de riqueza produzida e o acesso aos benefícios da civilização'. [...]. Salazar procurava convencer os portugueses que governava com a 'autoridade necessária' e a 'liberdade possível', sendo que a manutenção de cada um desses princípios representava a garantia do outro. Aos portugueses não restaria opção senão adequar-se a essa realidade.

$\mathrm{Na}$ prática, Salazar assumiu posições políticas autoritárias, sufocou as vozes discordantes e ganhou forte apoio dos direitistas. Sua postura sobre a relação entre Estado e Igreja à defesa dos valores católicos também lhe permitiam conquistar simpatia do clero. ${ }^{250}$

Eduardo Lourenço, após análise da implantação Estado Novo português, afirma que houve

[...] regresso maciço da antiga e indiscutível autoridade [...] mas sob a forma violenta do totalitarismo, pois sem ele não era possível recusar em bloco a herança de cento e poucos anos de 'tradição' liberal. Era esse o preço a pagar para reajustar $o$ País a si mesmo? Esse foi o designo e a pretensão do Estado Novo. ${ }^{251}$

${ }^{248}$ Cf. ROSAS, Fernando. História de Portugal: o Estado Novo (1926 - 1974).

249 "Marcelo Caetano ocupou vários cargos durante o regime salazarista, entre eles os de ministro das Colônias e ministro da Presidência do Conselho de Ministros (1955-1958). Nos anos 50 era considerado o número dois do regime, mas foi afastado por Salazar desse cargo por divergências internas. Aceitou, porém, assumir a funções destacadas no partido único, União Nacional, como presidente da Comissão Executiva. Até 1968, Salazar havia corporificado o regime ditatorial. Entretanto, sua condição precária de saúde terminaram por levar à sua exoneração da presidência do Conselho de Ministros e a nomeação do tal Marcelo Caetano, que gozava de prestígio dentro do regime mesmo sem ter o fôlego de Salazar. Marcelo Caetano era favorável a algumas reformas. [...]. [Mas], Já nos dois primeiros anos de governo ficou claro que a anunciada 'primavera marcelista' era uma bobagem. Tudo continuava igual e as eleições mais uma vez não mostraram surpresas.” Em 25 de abril de 1974, “os lideres do MFA exigiram a deposição de Marcelo Caetano (que acabou fugindo para o Brasil) (SCOTT, Ana Silva. Os portugueses. São Paulo: Contexto, 2010, p. 341-347).

${ }^{250}$ Ibid., p. 328-330.

251 LOURENÇO, Eduardo. O labirinto da saudade: psicanálise mítica do destino português. Lisboa: Dom Quixote, 1982, p. 29. 
Foi, portanto, o movimento militar de 1926 que marcou o início de um complexo período político português, cuja relevância está ligada às tensões relativas ao fim da ditadura militar para a instauração do Estado Novo sob o comando de Salazar. Este, habilmente, conseguiu eliminar, integrar e comprometer "o quadro mais ou menos caótico e pulverizado do que eram as direitas portuguesas e no emaranhado de interesses contraditórios que dividiam as 'forças vivas"”,252, a fim de criar uma ficção, uma "imagem" oficial de Portugal. Eduardo Lourenço, analisando esse período, afirma que Salazar conseguiu criar uma imagem de Portugal tão "perfeita" que a ela não se pudesse confrontar outra: fez o país acreditar que era modesto e, para atingir tal fim, "esculpiu" uma lusitanidade ligada a um presente e a um passado, fundamentando-se numa mitologia arcaica e reacionária. Salazar, segundo o teórico, desloca as imagens anteriores

[...] por uma ficção ideológica, sociológica e cultural mais irrealista ainda que a proposta pela ideologia da republicana, por ser ficção oficial, imagem sem controle nem contradição possível de um país sem problemas, [...] solução ideal que conciliava o capital e o trabalho, a ordem e a autoridade com um desenvolvimento harmonioso da sociedade. [...] O sistema chegou a uma tal perfeição na matéria que não parecia possível contrapor uma outra imagem de nós mesmos àquela que o regime tão impune mas tão habilmente propunha sem que essa imagem-outra (não apenas ideológica, mas cultural) aparecesse como uma sacrílega contestação da verdade portuguesa por ele restituída à sua essência e esplendor. ${ }^{253}$

E foi com essa "imagem irrealista" que o país viveu sob o "fascismo togado" 254 conservador, que se opunha a instabilidades e desordens. Salazar se autodefiniu como "pobre, filho de pobre" e fez uso de um preceito doutrinário que, segundo sua compreensão do mundo, do homem e do ser social, buscaria "moldar" a sociedade conforme os novos valores, tentaria "educá-la e formá-la imperativamente na moral nacionalista, corporativa e cristã, que haveria de presidir à política, às relações de trabalho, aos lazeres, à vida em família, à educação dos jovens ou à cultura em geral’"255.

Portanto, o novo regime assentou-se sobre o autoritarismo, o corporativismo, o antiparlamentarismo e o anticomunismo. Esses princípios são

\footnotetext{
${ }^{252}$ ROSAS, Fernando. História de Portugal. Lisboa: Estampa, V. 7: O Estado Novo (1926-1974), 1998, p. 142.

${ }^{253}$ LOURENÇO, Eduardo. O labirinto da saudade, cit., p. 30-31.

${ }^{254}$ ROSAS, Fernando. História de Portugal, cit., p. 251.

${ }^{255}$ Loc. cit.
} 
perceptíveis na fábula Dinossauro Excelentíssimo, em que observamos a concentração das decisões nas mãos do Imperador, o corporativismo entre seus pares - "Hoje está historicamente provado que os dê-erres eram dotados de grande instinto gregário" 256 - e a rigorosa censura aos que se opunham às ordens, pois estavam "os mexilhões descontentes, os Pedintes Voadores. [...] a falar praticamente por sinais" ${ }^{257}$. Nessa fábula, vários fragmentos de texto exibem um diálogo entre história e ficção. Embora o autor tenha realizado pesquisas e levantamento documental, seu vínculo é com os procedimentos da estrutura do enredo, enquanto produtor de sentido, pois o texto ficcional pode tratar livremente de aspectos ausentes no discurso histórico.

\subsection{O Jogo do Olho Vivo}

Numa cena do romance $O$ Delfim, o narrador reencontra o personagem Padre-novo e ambos relembram um jogo em que, a partir de um tema, começa-se, através de raciocínio lógico, a selecionar palavras que estejam relacionadas à questão proposta. Em seguida, o jogador vai encadeando outras palavras que permitam desenvolver o assunto cifrado nas palavras, de modo que se tenha um "relato condensado e cifrado" 258 sobre o tópico apresentado: "Caça é de caras", responde ele. "caça-tiros... tiros-revolução... revolução-subversiva. Está a ver? Com três associações resolvi a questão." 259

Assim surge o Jogo do Olho Vivo. Na sequência da mesma cena, o Padrenovo afirma: "Só aos portugueses atentos é concedido o privilégio de jogar ao Olho Vivo". ${ }^{260}$ Esse privilégio, concedido a alguns portugueses para decifrarem as ideias condensadas nas entrelinhas da narrativa, só se torna possível se o leitor atento for capaz de resgatar nos intertextos a sutil ironia que a voz do narrador revela. A ironia intertextual torna possível o jogo da dupla leitura, mas não são todos os leitores que irão alcançá-la. Segundo Umberto Eco, a ironia "seleciona, e privilegia os leitores intertextualmente avisados, embora não exclua os menos

\footnotetext{
${ }^{256}$ PIRES, José Cardoso. Dinossauro Excelentíssimo, cit., p. 63.

${ }^{257}$ Ibid., p. 72.

${ }^{258}$ PIRES, José Cardoso. O Delfim, cit., p. 168.

259 Loc. cit.

${ }^{260}$ PIRES, José Cardoso. O Delfim . Lisboa: Dom Quixote.1999, p 168.
} 
avisados" 261 . Para Eco, o leitor que consegue ler as referências compreende "os efeitos de enfraquecimento ou de mutação de significado (quando a citação se insere em um contexto absolutamente diverso daquele da fonte), a remissão geral ao diálogo ininterrupto que se desenrola entre os textos" 262 .

Em Dinossauro Excelentíssimo, o leitor pode entender, na superfície, a fábula do dinossauro e dos mexilhões como a luta entre o mais fraco e o mais forte, mas pode também, pelas pegadas intertextuais, decifrar os enigmas espalhados pelo narrador ao longo do enredo. Uma vez jogadas as pistas sobre a história, o que se consegue é a participação ativa do leitor, na medida em que ele é levado a praticar o Jogo do Olho Vivo.

Para Maria Lúcia Lepecki, a presença da intertextualidade na narrativa cardosiana "se constrói, em definitivo, sob a égide da chamada 'ironia de menção",263. Tal procedimento busca "re-consciencializar e re-problematizar

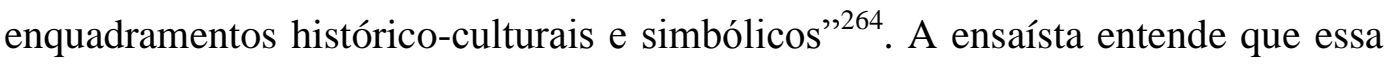
apropriação pode ser perceptível em várias esferas do conhecimento. Na fábula em análise, por exemplo, observamos provérbios que, embora apareçam algumas vezes às avessas, ou atravessados pela ironia, advêm da sabedoria popular: "mais vale um rico na mão do que dois pobres a voar" ${ }^{265}$ tem como propósito questionar a distribuição de renda no Reino dos Mexilhões (ou entre os mexilhões). Esse recurso pode aparecer dissimulado na voz do narrador e, nessa situação, quase não o percebemos. Desse modo, se "no primeiro caso o discurso cardosiano encena [...] a natureza histórica de qualquer dizer literário, no segundo a menção, disfarçada, obriga-nos a entrar naquele jogo chamado 'do olho vivo",266, tão "propício a estabelecer cumplicidade intelectual, afectiva e emocional entre textos e leitores"267.

Nesse jogo de analogia, podemos lançar mão de algumas palavras-chave para desvendar as alusões que subjazem no texto: Imperador - Missionário -

\footnotetext{
${ }^{261}$ ECO, Umberto. Sobre a literatura. Rio de Janeiro: Record, 2003, p. 206.

${ }^{262}$ ECO, Umberto. Sobre a literatura, cit., p. 206.

263 LEPECKI, Maria Lúcia. Delfins, corvos e dinossauros: interseções discursivas em José Cardoso Pires, cit., p. 202.

${ }^{264}$ Loc. cit.

${ }^{265}$ PIRES, José Cardoso. Dinossauro Excelentíssimo, cit., p. 50.

266 LEPECKI, Maria Lúcia. Delfins, corvos e dinossauros: interseções discursivas em José Cardoso Pires, cit., p. 202.

${ }^{267}$ Loc. cit.
} 
palavra - Jesus - Dinossauro. Nessa sequência de palavras-chave, percebemos que existe ligação entre elas porque a imagem do líder aparece em suas várias faces, embora ofereça sentidos diferentes. Cabe ao leitor seguir os rastros da vida do Imperador-Dinossauro, acompanhar a viagem do "salvador".

Parece que, ao longo da fábula, o narrador nos coloca a par do Jogo do Olho Vivo, pois o personagem Imperador "teria vindo ao mundo iluminado por Deus" ${ }^{268}$, teria estudado e acreditado nos compêndios escolares: "Nessa altura chamava-se Francisco ou Vitorino; Adolfo, talvez Adolfo Hirto; ou Benito Marcolino, Zé Fulgêncio, Sebastião Desejado - não interessa." ${ }^{269}$ Percebemos que o narrador, ao modificar as letras dos nomes, tem o objetivo de ironizar, visto que os personagens evocados nessas mudanças são também tomados como iluminados e vieram para "salvar" os "desorientados". Seguindo esse raciocínio, fica fácil compreender essa estratégia que delineia, no espaço histórico do século $\mathrm{XX}$, a missão dos atores que exerceram o totalitarismo, sob suas múltiplas designações, e foram representados na literatura como "novos salvadores [...] prontos a lançar-se contra a adversidade, a dominar o caos e a salvar" "rebanho de desorientados"271.

\section{“RESPEITO, CIDADÃOS IGNORANTES!}

Dinossauro, criatura marcada desde o berço, estava escrito que iria subir muiiiitíssimo na asa da compostura, por cima dos casebres da aldeia e do palácio dos ricos, e que teria de tirar um curso que lhe desse para governar toda a gente. ${ }^{272}$

A narrativa é permeada de intertextos, relacionados aos fatos históricos que remetem à situação política do país ou à biografia de Salazar, que é caracterizado na fábula como um Imperador-Dinossauro. Essa identificação nos possibilita fazer um paralelo entre algumas características e atitudes do ditador Salazar e as do personagem Imperador. Entre vários exemplos, citamos aquele em que se evidencia a postura eremita do Imperador, que, em determinado momento da narrativa, evita o convívio social, deixa simplesmente de ouvir-se e de ouvir o outro, apontando para uma tendência à introspecção, que resulta na pessoa

\footnotetext{
${ }^{268}$ PIRES, José Cardoso. Dinossauro Excelentíssimo, p. 17.

${ }^{269}$ Loc. cit.

${ }^{270}$ VUILLEMIN, André. Ditador. In: BRUNEL, Pierre (Org.). Dicionário de mitos literários. Rio de Janeiro: José Olympio, 2000, p. 249.

${ }^{271}$ PIRES, José Cardoso. Dinossauro Excelentíssimo, cit., p. 21.

${ }^{272}$ Ibid., p. 19.
} 
solitária na qual se transforma o Imperador-Dinossauro (Salazar): "Estranhamente, muito estranhamente, de maneira inquietante até - também ele começava a notar uma certa dificuldade em se ouvir. Seria por falta de diálogo ${ }^{273}$ Importa também ressaltar que esse desejo do Dinossauro de ficar isolado expandese para fora do país. Ele sentia orgulho por conseguir viver isolados de todos, agarrado às lembranças da infância:

Estava ele assim, abraçado à estátua, quando nas acácias do lado de lá das vidraças pousaram dois pardais de telhado. Isso deve tê-lo levado para grandes longes em pensamento: para becos de bacharel e sublinhados de sebentas, e por estradas de camioneta ruça e trotes troquetroque, de burro alegre, recuando, recuando, amparado na sua santa mãe (mas sempre de costas, sempre voltado para a cidade) até à infância de camponês entre pinheiros e maçãs na arca.

À beira da janela tinha os pardais em liberdade, mas mais à mão, mais no tempo, estava a mesa do conselho imperial com as pastas alinhadas e as cadeiras vazias. Surdo, um magnífico como ele ficaria à mercê do nem-se-imagina, das armadilhas sobre armadilhas dos ambiciosos conselheiros. Lá iria. Por agora estava decidido a cortar com os continentes, pesasse a quem pesasse.

Como cortou. Desistiu de lhes dirigir palavras; prescindiu, é o termo. Para tanto pôs a funcionar o seu conhecido princípio de causa e efeito, que era o seguinte: se um verdadeiro imperador não se pode ouvir a ele mesmo não interessa que os outros o ouçam, ou então a lógica é uma batata. ${ }^{274}$

Além de salientar traços da biografia de Salazar, é possível destacar algumas cenas ou temas da narrativa que dialogam com fatos históricos da época do Estado Novo, como a Câmara de Torturar Palavras. Esta pode remeter aos métodos de censura (ou aos espaços de tortura) e fazer uma analogia à ação do lápis azul, que tirava de circulação os textos que criticassem o sistema vigente: era na máquina infernal que o Imperador-Dinossauro mutilava as "palavras". Vejamos alguns exemplos que aludem à ação dos censores durante o Estado Novo Português: "O exemplar censurado, imagine! As anotações, as passagens, as páginas cortadas pelo célebre lápis azul da censura, [...] Por exemplo, certas expressões do gênero filho da mãe, dor de corno, catano e outras assim, tudo abaixo, tudo excomungado.,"275

Nessa fábula cardosiana, além da intertextualidade com fatos históricos do Estado Novo e menções que remetem à biografia de Salazar, há outras

\footnotetext{
${ }^{273}$ PIRES, José Cardoso. Dinossauro Excelentíssimo, cit., p. 106.

${ }^{274}$ Ibid., p. 107-108 (grifo nosso).

275 PORTELA, Arthur. Cardoso Pires por Cardoso Pires, p. 34-35.
} 
"interseções" que nos permitem visualizar ainda, de modo implícito, fatos e episódios ligados principalmente ao universo religioso. Percebemos a relação que o narrador estabelece entre a figura do missionário, o Imperador Dinossauro, que tortura e cala os mexilhões, e o messias, Jesus Cristo. No entanto, o narrador deixa de relacionar diretamente Jesus Cristo ao filho de Deus, mas o remete a uma figura milenar, o Mestre, intérprete que tem a palavra como instrumento de libertação. Já o Imperador-Dinossauro, que é também uma figura milenar, utiliza a palavra como instrumento, não para promover a liberdade, mas para aprisioná-la a fim de modificar seu sentido.

Essa estrutura intertextual subjacente à narrativa da fábula é apresentada através da ironia no sentido que lhe deu Fábio Quintiliano. De acordo com o estudioso, a ironia está associada à ideia de oposição, "uma vez que a ironia afirma para dizer outra coisa, isto é, para negar, e vice-versa"276. Em outras palavras, ao apresentar nas entrelinhas, ou na ausência, a maneira como deveria agir um grande líder, um messias, Cardoso Pires inverte o sentido de messias para negá-lo, pois o que encontramos na superfície do texto é um líder que se comporta de forma contrária ao que se espera; em sua origem, um camponês humilde e iluminado por Deus, de quem se esperava que trouxesse "alguma novidade nova. Traria?"277 Na narrativa, aquele que fora um dia camponês se transformara em ditador.

Sobre esse aspecto, Lepecky identifica, nas alusões à Escritura Sagrada, uma complexa rede de intertextos entre a fábula Dinossauro Excelentíssimo e o Novo Testamento, sobretudo como tropo de oposição, “inversão paródica da figura de Cristo" ${ }^{278}$. Desse modo, a ensaísta a divide em duas partes: a primeira trata das mais conhecidas histórias que têm estreita ligação com a História Sagrada; já a segunda depende de um conhecimento mais profundo do leitor sobre os escritos dos Evangelistas Lucas, Mateus e João. Essa estratégia narrativa é caracterizada por um refinado mecanismo de "acoplagens e justaposição, casando tempos e amalgamando espaços da vida de Cristo (sempre revertida em

\footnotetext{
${ }^{276}$ QUINTILIANO, M. Fábio. Institution oratoire apud HANSEN, João Adolfo. Alegoria: construção e interpretação da metáfora. São Paulo: Ed. Unicamp, 2006, p. 29.

${ }^{277}$ PIRES, José Cardoso. Dinossauro Excelentíssimo, cit., p. 37.

${ }^{278}$ LEPECKI, Maria Lúcia. Delfins, corvos e dinossauros: interseções discursivas em José Cardoso Pires, cit., p. 206.
} 
vida de 'Dinossauro')" 279 com a finalidade de provocar o humor sarcástico dessa "história às avessas", a fábula do Dinossauro Excelentíssimo.

Seguindo o percurso do personagem Imperador, podemos compreender que o narrador não copia a trajetória da vida de Jesus, mas acompanha o entrelaçamento de certos rastros com os quais dispõe conforme sua intenção em enfatizar e/ou criticar as atitudes do ditador na fábula. Interessa ressaltar que percebemos o eco de três narrativas que resultam desses intertextos, pois a fábula se estrutura a partir de fatos da história cultural do ocidente metonimicamente representados pela imagem de Jesus Cristo (como o Messias), fatos da História do Estado Novo português e fatos da biografia de Salazar. Todos são recriados a partir da leitura do contador de histórias para a sua filhinha sobre a vida de um Imperador-Dinossauro. Logo, há estrategicamente uma estreita ligação entre a biografia de Salazar e a do Imperador-Dinossauro, e a presença de cenas das Escrituras tem a finalidade de complementar a visão sarcástica e irônica do narrador sobre a vida de um ditador. Através dessas associações, chegamos afinal ao Jogo do Olho Vivo, em que constam os fatos ligados à origem humilde de Jesus (intertextualidade com o universo histórico-cultural), de Salazar (referência intertextual com a biografia de Salazar) e do Imperador-Dinossauro, transcrita no exemplo a seguir:

[...] os habitantes da aldeia, levados pela inveja e pela intriga, tinham-se posto a insultar os pais sacrificados que, na opinião deles, não passava de uns perdulários a correr atrás do sonho de um filho doutor.

"LOUCOS! GANACIOSOS!"

"RENEGADOS!"

"MÃOS ROTAS!"

Trabalhos. Desgraças que acontecem a quem se vê obrigado a suportar a injustiça do semelhante para cumprir um destino sublime.

Mas, como diz o outro, o amor dos pais tudo vence. ${ }^{280}$

De acordo com o fragmento do texto, sobretudo a menção que remete ao nascimento de Cristo, reconhecemos, de imediato, semelhança entre o relato da fuga da família do Imperador (Anexo - Figura 1) para a cidade dos doutores e a

\footnotetext{
279 LEPECKI, Maria Lúcia. Delfins, corvos e dinossauros: interseções discursivas em José Cardoso Pires, cit., p. 206.

${ }^{280}$ PIRES, José Cardoso. Dinossauro Excelentíssimo, cit., p. 24.
} 
história da Família Sagrada, que fugiu para o Egito porque temia que o Menino Jesus fosse morto. Vejamos:

Supõe-se, está vagamente escrito, que esse imperador veio realmente do nada. Que nasceu algures numa choupana, filho de gente-nada ou pouca-coisa, camponeses ao desabrigo. Que muito possivelmente estudou por cartilhas de aldeia; por catecismo, também. Mais: a acreditar nos compêndios das escolas, teria vindo ao mundo iluminado por Deus - e tanto assim que, ainda muito mocinho, fez ciências entre os doutores. ${ }^{281}$

Como revela o texto bíblico, o Rei Herodes ordenara o assassinato de todos os meninos nascidos no mesmo período de Jesus por receio de perder seu reino para aquele que seria o Rei dos cristãos: (Mateus 2. 13-15).

\footnotetext{
${ }^{13}$ Depois que os magos partiram, o Anjo do Senhor apareceu em sonho a José, e lhe disse: "Levante-se, pegue o menino e a mãe dele, e fuja para o Egito! Fique lá até que eu avise. Porque Herodes vai procurar o menino para matá-lo. ${ }^{14}$ José levantouse de noite, pegou o menino e a mãe dele e partiu para o Egito. ${ }^{15}$ Aí ficou até a morte de Herodes, para se cumprir o que o Senhor havia dito por meio do profeta: "Do Egito chamei o meu filho. ${ }^{282}$ Mateus 2.13-15
}

De modo semelhante, a família do Imperador deixou a cidadezinha em que vivia e conduziu o filho por uma caminhada cujo objetivo era cumprir uma missão divina, no Reino dos Mexilhões. Lá, ele passou a criar uma nova realidade através do dom de manipular as palavras para dominar os seus súditos.

Outra citação está relacionada ao hábito de os judeus conduzirem seus filhos homens durante a Páscoa ao Templo de Jerusalém, onde os meninos eram introduzidos na comunidade judaica. A família de Jesus manteve essa tradição ao levá-lo ao encontro dos doutores, Cristo demonstra o domínio da palavra e o conhecimento das leis, quando conversou e debateu com os que ali estavam. Nesse episódio, os doutores sentiram grande admiração por Jesus, pois foi um menino quem os interrogou e os ouviu com muita sabedoria. Essa cena se encontra relatada no Evangelho de Lucas:

${ }^{41}$ Os pais de Jesus iam todos os anos a Jerusalém, para a festa da Páscoa. ${ }^{42}$ Quando o menino completou doze anos, subiram para a festa, como de costume. ${ }^{43}$ Passados os dias de Páscoa, voltaram, mas o menino Jesus ficou em Jerusalém, sem que seus pais o notassem. ${ }^{44}$ Pensando que o menino estivesse na caravana, caminharam um dia inteiro. Depois começaram a procurá-lo entre parentes e conhecidos. ${ }^{45}$ Não o

\footnotetext{
${ }^{281}$ PIRES, José Cardoso. Dinossauro Excelentíssimo, cit., p. 17.

${ }^{282}$ Mateus 2.13-15. BÍBLIA. Trad. Ivo Storniolo. São Paulo: Paulinas, 1993, p. 1.239.
} 
tendo encontrado, voltaram a Jerusalém à procura dele. ${ }^{46}$ Três dias depois, encontraram o menino no Templo. Estava sentado no meio dos doutores, escutando e fazendo perguntas. ${ }^{47}$ Todos os que ouviam o menino estavam maravilhados com a inteligência de suas respostas. ${ }^{48}$ Ao vê-lo, seus pais ficaram emocionados. Sua mãe lhe disse: "Meu filho, por que você fez isso conosco? Olhe que seu pai e eu estávamos angustiados, à sua procura." "Jesus respondeu: "Por que me procuravam? Não sabiam que eu devo estar na casa do meu Pai?" ${ }^{50}$ Mas eles não compreenderam o que o menino acabava de lhes dizer.

${ }^{51}$ Jesus desceu então com seus pais para Nazaré, e permaneceu obediente a eles. E sua mãe conservava no coração todas essas coisas. ${ }^{52} \mathrm{E}$ Jesus crescia em sabedoria, em estatura e graça, diante de Deus e dos homens. ${ }^{283}$

Na fábula de Cardoso Pires, encontramos alusão a essa passagem bíblica, quando o aluno-Imperador chegou à Universidade dos Mestres. Essa cena é ironicamente descrita, visto que tanto os padres quanto os doutores Dê-erres foram os primeiros a apoiarem a ascensão do camponês ao cargo de Imperador:

Pai, mãe e filho acharam-se no meio de muitas ruas apertadas e antigas, Havia arcos de pedra e brasões a certas portas. Oratórios também: muitos. E padres, padres e mais padres, o que ali ia de padres só visto.

$[\ldots]$

Recomeçou a marcha que agora era mais difícil, quase a pique e por passagens estreitíssimas e cheias de gente embuçada. E neste andar deu de caras com um grande mosteiro ou coisa semelhante - mosteiro, digo bem, visto que tinha sino na torre e claustros de pedra antiga. Silêncio e ponto final; estava-se na Universidade, deduziu o nosso rapaz.

Empoleirado em altos cadeirões

\section{OS MESTRES RECEBERAM-NO COM DUREZA}

\section{'QUEM É ESTE'}

pareciam perguntar. Somente, não se lhes ouviu a mínima palavra e nem era de esperar que se ouvisse porque aqueles mestres não diziam senão o que estava dito nos livros antigos e nunca se dignavam nomear pessoas ou factos que não tivessem sido nomeados pelos mestres defuntos, e com o devido respeito. ${ }^{284}$

Como vimos, Cardoso Pires faz alusão à figura de Jesus, desde o início da sua fábula, associando-o à figura do Imperador-Dinossauro ainda menino, em sua viagem para a cidade. Mais tarde, torna a articular o texto bíblico, especificamente no momento em que Jesus ressuscita (ao terceiro dia de sua morte), à narrativa de um ditador que parece ter sido traído e crucificado por seus conselheiros (os DêErres), padecendo nas mãos deles durante cem dias e cem noites.

\footnotetext{
${ }^{283}$ Lucas 2.41-52. BÍBLIA, cit., p. 1.313.

${ }^{284}$ PIRES, José Cardoso. Dinossauro Excelentíssimo, cit., p. 34-35.
} 
Quando os guardas da Torre das Sete chaves chegaram à sala do Conselho foi como se tivessem desembarcado num campo de batalha. [...]. E verde, verde, esmagado pelo irmão verde, o Douktor Dinossaurus jazia, de olhos esbugalhados, sem brilho. ${ }^{285}$

$[\ldots]$

E (os conselheiros) desandaram à procura de um novo imperador.

Os médicos de maior ciência, os mais médicos, baixaram a cabeça: Okay, iam tentar pedir ajuda aos cirurgiões-artistas da Comarca dos Doutores, discutiram os prós e os contras $[\ldots]$

\section{ALARME GERAL}

De ponta a ponta do Reino os sinos badalaram a péssima notícia. Os médicos iam formigando por cima do cadáver; mas com poucas esperanças [...]. Diziam: vamos a ver, vamos a ver.

Houve velório nos outeiros, altares à volta do retrato do imperador. Discursos também, e muitos. Versos de despedidas, lágrimas de sobre-aviso. Os jornais iam anunciando em letras de caixão alto que para grandes povos, grandes desastres.

$[\ldots]$

Cem dias e cem noites trabalharam [os médicos] no Imperador, apertados no difícil limite do entre a vida e a morte. [...]. Cem dias e cem noites é obra, mas continuaram. Mais cem dias e outros cem, e de repente, caíram para trás, espantados: o corpo começava a despertar, a emergir.

"RESSUSCITOU!",286

Quando Dinossaurus, o Magnífico, acordou e se viu rodeado de fidalgos habituais, a primeira coisa que fez foi pedir um espelho. Mirou-se, remirou-se, apalpando o rosto, reconhecendo-se. A seguir comunicou em voz sumida:

"PARA SEMANA,

\section{REUNIÃO DO CONSELHO.”}

O cirurgião mais sábio ia a avançar um passo para lhe recomendar prudência, tempo ao tempo. Mas o Imperador segredou-lhe:

'NÃO FAZ MAL, ELES SE REUNEM SEM

MIM. EU SÓ LEIO OS RELATÓRIOS.”

E ponto final. Despediu toda a gente com o gesto de o deixarem em paz. ${ }^{287}$

Por fim, sabemos que Jesus Cristo cumpriu sua missão, ascendendo aos céus para juntar-se ao Pai, enquanto o Imperador-Dinossauro é eternizado através de uma imagem fotográfica, uma estátua. Jesus Cristo morre para salvar a

\footnotetext{
${ }^{285}$ PIRES, José Cardoso. Dinossauro Excelentíssimo, cit., p. 115.

${ }^{286}$ Ibid., p. 125-127.

${ }^{287}$ Ibid., p. 130-131.
} 
humanidade, e o Imperador-Dinossauro, esperado e desejado como um Messias, é substituído por outro.

Portanto, nas narrativas cardosianas, os intertextos, ou interseções que se apresentam no texto, como diz Lepecky, são recorrentes. Elas ocorrem algumas vezes como recurso para desenvolver a ironia, a metáfora, a paródia, a sátira; outras, para referir conhecimentos milenares e recentes nos mais diversos campos do saber, que assumem a função de estrutura subjacente, construída sob a imagem alegórica de personagens ou de fatos históricos e culturais. 


\title{
5 A IMAGEM FRAGMENTADA DO PODER
}

\begin{abstract}
Homero transformou em imagem sensível as especulações filosóficas sobre as paixões humanas, dando, assim, simultaneamente a seus conceitos um corpo, animado por encantadoras imagens. [...]. A sutileza da alegoria há de aguçar o espírito mais perfeitamente educado. ${ }^{288}$
\end{abstract}

Na obra de Cardoso Pires, há textos que revelam, através da alusão, um plano de construção de efeitos plásticos, que retomam imagens emergentes dos enredos e criam silenciosamente outras histórias. Em hipótese, entendemos que, quando percebidas e alinhavadas, as histórias concretizam ideias abstratas, conceitos que se tornam narráveis a partir da justaposição de pequenos fragmentos de textos alheios que, entrelaçados, formam as imagens pretendidas pelo autor, ou um mosaico composto de linhas múltiplas. O autor afirma que é muito mais "provocado pela pintura do que pela literatura, mas de longe"289; por esse motivo, acreditamos que ele "joga com os signos como um logro consciente, cuja fascinação saboreia, quer fazer saborear e compreender. O signo - pelo menos o signo que ele vê - é sempre imediato, regrado por uma espécie de evidência que lhe salta aos olhos."290

Segundo Cardoso Pires, a fábula Dinossauro Excelentíssimo ${ }^{291}$ tem origem na imagem de uma fotografia realizada em Londres em outubro de 1969: "Tenhoa aqui entre lembranças que mandei de mim e lá estou eu, voltado para a pátria e para os meus - mas com a pata dum dinossauro a ameaçar-me pelas costas."292 Dando sequência a esse depoimento, o autor conta que, em companhia de um

\footnotetext{
${ }^{288}$ CURTIUS, Ernst Robert. Literatura européia e Idade Média latina. Trad. Teodoro Cabral e Paulo Rónai. São Paulo: Hucitec / Edusp, 1996, p. 265.

${ }^{289}$ ALVES, Clara Ferreira (Dir.). José Cardoso Pires. Documentário, cit.

${ }^{290}$ BARTHES, Roland. Aula, cit., p. 40.

${ }^{291}$ Dinossauro Excelentíssimo teve várias edições. A primeira foi a da Editora Arcádia, Lisboa, 1972, com ilustrações e capa de João Abel Manta. Outra edição, limitada, constituída de 15 exemplares, foi feita pela Ars Bibliografica, com manuscritos do autor e ilustrações originais de João Abel Manta - Galeria 111, Lisboa, 1972. A sexta edição ficou a cargo de uma nova editora: Publicações Europa-América, Lisboa, 1974. A obra foi posteriormente incluída na coletânea de contos O burro em pé, em 1979, e em A República dos Corvos, em 1988.

${ }^{292}$ PIRES, José Cardoso. Post-scriptum. In:___. O burro em pé, cit., p. 117.
} 
amigo fotógrafo, visitara vários pontos da cidade de Londres, chegando finalmente a um parque, um lugar abandonado e povoado por

[...] fantasmas [...], répteis gigantes, répteis de asas, aves dentadas, isso e toda aquela família desvairada do nosso planeta de há cinquenta milhões de anos, sem esquecer o dinossauro. Tudo em fóssil, já se vê, ou, melhor, em enormes formas de cimento copiadas do grande atlas das monstruosidades.

[...] Enquanto eu era ali fotografado [...] Pus-me a pensar no Tiranossauro, com os seus dez metros de comprimento e a sua dentuça assanhada, e saiu esta estória. ${ }^{293}$

Esse relato, extraído do Post-Scriptum de O burro em pé, será tomado como base para desenvolvermos nossa análise, destacando a influência da imagem e do olhar na construção das narrativas cardosianas. O autor, em entrevista a Arthur Portela, afirma que o cinema e a pintura o estimulam na criação de suas "cenas". Ele diz que, no cinema, "o que prevalece é o enfocamento visual da maneira de contar" ${ }^{294}$; em relação à pintura, afirma que é, dentre outros discursos, uma fonte desafiadora para "apanhar ideias". Sobre essa influência das artes - sobretudo da pintura - em sua obra, Cardoso Pires ressalta principalmente a concepção de pintura de Paul Klee: "a pintura não restitui o visível, torna-o o visível”"295, ou seja, os olhos do pintor são capazes de captar a imagem imanente do objeto ${ }^{296}$. Considera também a percepção de Henri Matisse, o qual busca retratar as relações entre as coisas. Uma vez que Cardoso Pires apreende a visão desses dois grandes

\footnotetext{
${ }^{293}$ PIRES, José Cardoso. O burro em pé, cit., p. 117.

${ }^{294}$ PORTELA, Arthur. Cardoso Pires por Cardoso Pires, cit., p. 67.

295 “As noções de 'visível' e de 'legível' encontram-se estreitamente ligadas uma a outra mas, apesar disso, diferem bastante. O 'visível' remete para o modo geral e espectacular do 'aparecer'. É, antes de mais, revelação. O que nos maravilha numa imagem é o facto de modificar a nossa visão do mundo de uma forma surpreendente e irresistível, que pode até chegar a transformar a nossa percepção do real, isto é, o próprio real: 'Não havia nevoeiro em Londres antes de Whistler o ter pintado', observou Oscar Wilde. 'A arte não reproduz o visível, torna visível': Foi através desta fórmula que Paul Klee inaugurou a era moderna da arte ocidental, marcando a sua ruptura com o dever de 'representar', a cuja lei estava sujeita desde há vários séculos. O 'legível' releva, também ele, a revelação, mas de um modo singular, combinando o visível com um dado que lhe é exterior, na medida em que implica uma forma de comunicação específica: a escrita. Quer surja em sentido literal ou metafórico, o legível implica sempre 'o escrito'. Por isso, a revelação que propõe não é da ordem do fascínio ou sequer da surpresa, mas da reminiscência. Enquanto que o visível deve a sua eficácia e o seu poder de atracção ao efeito de enigma suscitado pela novidade pura, o legível extrai o seu poder da associação mnemónica gerada entre um dispositivo visual que poderia parecer, à partida, ornamental ou gratuito e uma estrutura gráfica que nos permite nela desvendar sentido." (CHRISTIN, Anne-Marie. Legível/Visível. Dicionário crítico de arte, imagem, linguagem e cultura. Lisboa: Centro de Estudos de Comunicação e Linguagens da Universidade Nova de Lisboa / Unidade de Arqueologia da Universidade do Minho (UAUM). Disponível em: $<$ http://www.arte-coa.pt/index.php?Language $=$ pt $\&$ Page $=$ Saberes $\&$ SubPage $=$ ComunicacaoELi nguagemLinguagem $\& M e n u 2=A u t o r e s \& S l i d e=67>$. Acesso em: 22 out. 2013).

${ }^{296}$ PORTELA, Arthur. Cardoso Pires por Cardoso Pires. Lisboa: Dom Quixote, 1991, 69.
} 
pintores, as noções de pintura de cada um desses artistas podem talvez se completar na escrita cardosiana, isto é, a narrativa de Cardoso Pires pode tornar visíveis as relações entre os “objetos”. Diz o autor:

Dum ponto de vista mais imediato e mais pessoal, a pintura apresenta-se como uma incitação à rebeldia, provoca em mim uma vontade extremamente palpável de transgredir a matéria e a ordem formal da escrita. Os pintores compreendem isto perfeitamente, os bons pintores são frequentemente os leitores mais agudos duma obra de ficção. Ah, sim, sem dúvida. Pomar, por exemplo, João Abel ${ }^{297}$ [...]. Os pintores quando lêem têm uma aproximação visual menos imediata com a escrita do que aquela que tem o homem que não vive da prática da imagem, é o que eu penso. ${ }^{298}$

A "prática de imagem" percebida nas narrativas cardosianas talvez resida nessa transgressão de matéria, pois a imagem permeia seus enredos, quer como estratégia para tornar visível o que se está olhando, mas não se vê, ou não está legível, quer como procedimento para demonstrar as relações entre as imagens que no texto verbal é narrável ou dissertada. Esse jogo com a imagem pode ser entrevisto nas intertextualidades relacionadas às pequenas dissertações narráveis, que se configuram através de diálogos silenciosos entre os fragmentos de ruínas e que metaforicamente se entrecruzam para formar a imagem emergente do texto verbal. Portanto, a imagem como prática verbal é, segundo Octavio Paz, um

[...] conjunto de frases, que o poeta diz que unidas compõem um poema. Estas expressões verbais foram classificadas pela retórica e se chamam comparações, símiles, metáforas, jogos de palavras, paronomásias, símbolos, alegorias, mitos, fábulas, etc. Quaisquer que sejam as diferenças que as separam, todas têm em comum a preservação da pluralidade de significados da palavra sem quebrar a unidade sintática da frase ou do conjunto de frases. Cada imagem - ou cada poema composto de imagens - contém muitos significados contrários ou díspares, aos quais abarca ou reconcilia sem suprimi-los. [...] A imagem é cifra da condição humana. ${ }^{299}$

\footnotetext{
297 "Sendo uma das figuras mais representativas do design gráfico nacional, João Abel Manta ilustrou os anos de brasa que assinalaram a mudança de regime em Portugal, na sequência dos acontecimentos ocorridos no dia 25 de abril, há 37 anos. Poucos souberam representar como ele a ironia e a mordacidade, reveladas através do seu fascínio pela sátira contundente, evidenciada no Diário de Notícias nos finais da década de 60 do século passado. Com a passagem pelo Jornal de Letras, em 1981, por cujo arranque foi responsável ao nível da orientação gráfica, termina a epopeia: João Abel Manta abandona a ilustração e o cartoon e passa a dedicar-se exclusivamente à pintura." (João Abel Manta. In: arte-facto [hereges perversões]. Disponível em: <http://arte-factoheregesperversoes.blogspot.com.br/2011/04/joao-abel-manta.html>. Acesso em: 10 out. 2013). João Abel Manta foi também o ilustrador da primeira edição da fábula Dinossauro Excelentíssimo, da Arcádia, em 1972.

${ }^{298}$ PORTELA, Arthur. Cardoso Pires por Cardoso Pires, cit., p. 69.

299 PAZ, Octavio. Signos em rotação. Trad. Sebastião Uchoa Leite. Org. e rev. Celso Lafer e Haroldo de Campos. São Paulo: Perspectiva, 2006, p. 37-38 (grifo nosso).
} 
Indo ao encontro do pensamento de Paz a respeito da leitura e/ou tradução da imagem, afirma Alberto Manguel: “As imagens que formam nosso mundo são símbolos, sinais, mensagens e alegorias, ou talvez sejam apenas presenças vazias que completamos com o nosso desejo, experiência, questionamento."300

As referências feitas no capítulo anterior acerca das "interseções" presentes na fábula levam-nos a considerar outro procedimento presente na narrativa cardosiana: a questão da construção silenciosa de um fato (semelhante a um retrato, a um flash), de um personagem, ou mesmo de um espaço, que, através do tecido descritivo e/ou da citação de outras obras, passam a desdobrar-se em imagens que, no contexto da fábula, ganham ou agregam novos sentidos. Tecida desse modo, a narrativa tende a ganhar mais um significado além daqueles já entrevistos em suas intertextualidades, como um olhar crítico, que busca ressaltar a simultaneidade das inúmeras imagens metafóricas visíveis na fábula. Essa forma de construção parece funcionar como um recurso de criação literária que exemplifica a instauração de conflitos diluídos em cenários compostos pela aproximação entre a expressão literária inovadora e o contexto histórico-social.

Importa apontar a presença desse procedimento em outra obra cardosiana, o romance Alexandra Alfa, que apresenta esse recurso como estrutura de composição do enredo. Em leituras e análises por nós realizadas, identificamos como a imagem surge na narrativa a partir de referentes textuais de outros textos, porque a imagem completa indiretamente o clima de violência que paira no romance, é possível observar a concretização da ideia de poder e violência que paira sobre o enredo. Portanto, não é por acaso que a citação do "homem-pássaro" habita o romance Alexandra Alfa e parece alçar voo diretamente dos "álbuns de Max Ernst”. Além disso, o olhar do falcão na gravura de Ernst está direcionado para o espectador, e esse pode ser um dos exemplos característicos da técnica de colagem/montagem utilizada pelo pintor, capaz de revelar silêncios ou mundos silenciosos que permeiam a rede de sentidos na tela e na trama. Embora um leitor menos atento possa não percebê-la, essa imagem de homem-falcão acompanha a protagonista ao longo do romance e se entrecruza com outros fragmentos que, no

\footnotetext{
${ }^{300}$ MANGUEL, Alberto. Lendo imagem: uma história de amor e ódio. Trad. Rubens Figueiredo, Rosaura Eichemberg e Claúdia Strauch. São Paulo: Companhia das Letras, 2001, p. 21.
} 
conjunto, nos levam a perceber sua ligação estreita com a violência e com o medo no espaço do romance.

A gravura referida ${ }^{301}$ faz parte do quarto caderno de Max Ernst, ${ }^{302}$ de onde surge - da colagem de seus fragmentos - a imagem de um homem-pássaro segurando uma mulher desnuda pelos cabelos e cravando-lhe uma faca nos pés (Anexo - Figura 2). É desse desenho que ecoa o argumento da violência, pois na "parede espalmada a gravura dum homem-pássaro [...] tinha máscara de falcão, bico e olhos de falcão; suspendia uma madona nua pelos cabelos. Tudo muito nítido no desenho. Violentamente nítido, até.”303

Há de se considerar que o processo de colagem desloca a imagem de seu sentido originário. Desse modo, à ideia de violência podemos acrescentar a de poder, porque a gravura pode compor, através de seus fragmentos, a imagem metafórica da violência do poder. Essa gravura causa no leitor certo estranhamento, mantendo-se presente na narrativa, principalmente nos espaços ocupados pela personagem Alexandra: é sobre ela que incide o olhar do falcão, como se a vigiasse.

As percepções das descrições de ambientes ou personagens em Alexandra Alfa constituem um procedimento cuja função é condensar ou re-velar as cenas "pintadas" por mãos que conduzem tão habilmente o fio de navalha, à sombra da censura sobre os "textos alheios", que ligam intrinsecamente a forma ao conteúdo, isto é, a técnica da montagem não só vem permear a estrutura do romance, mas

\footnotetext{
${ }^{301}$ A referida imagem está inserida na obra Une semaine de bonté ou Les sept elements capitaux, produzida em cinco cadernos. A princípio seriam sete cadernos, um para cada dia da semana, mas foram reduzidos a cinco por problemas financeiros, neles configurando-se um mundo "caótico, povoado por figuras fantásticas e monstruosas" (FABRIS, Annateresa. Os folhetins perversos de Max Ernest. Anuário de literatura. V. 15, n. 1, p. 172, 2010).

${ }^{302}$ Max Ernst "é provavelmente um dos poucos artistas que reinventou a si mesmo ao longo de toda sua vida. Ao lado de Picasso, fez parte de alguns dos grupos e movimentos de vanguarda mais importantes do século 20. [...]. A capacidade de Max Ernst criar um universo e um olhar próprio, diferente e singular, o transforma em um dos artistas de referência no século 20 e também em um dos mais complexos e mutáveis. Dadaísta, surrealista, poliglota e ávido leitor, Ernst desenvolveu um universo absolutamente particular e pessoal. Por conta de sua deslumbrante e afiada inteligência, além da sensibilidade e senso de humor ácido e irônico, é possível encontrar influências de Ernst em toda a história do século. Essa mistura de curiosidade e constância que encaixa o discurso do artista é a base sobre a qual foi construído o olhar de Ernst" ("Max Ernst - Uma semana de bondade", MASP, SP. Revista Museu. Disponível em: <http://www.revistamuseu.com.br//naestrada/naestrada.asp?id=23636>. Acesso em: 25 out. 2010).

${ }^{303}$ PIRES, José Cardoso. Alexandra Alfa. Lisboa: Dom Quixote, 1999, p. 19 (grifo nosso).
} 
traz para a narrativa os significados socioculturais com os quais se podem organizar novos sentidos.

Por analogia, na fábula Dinossauro Excelentíssimo, encontramos também algumas imagens que compõem o cenário cinzento e os personagens que habitam o mundo sombrio da fábula, que é comumente silenciado pela censura. Lançando mão desse artifício, Cardoso Pires constrói a imagem do poder e da censura na fábula através da alusão metafórica, metonímica ou alegórica. O autor justapõe fragmentos que entrelaçam discursos sobrepostos a fim de tecer com palavras e imagens uma narrativa ambígua, constituída de tempos, espaços e personagens imaginários. Porém, todos os elementos citados são passíveis de remissão à ditadura de Salazar e, portanto, criam um diálogo com Portugal, buscando mais uma face de significado para os tempos difíceis vivenciados pelo povo português durante o regime ditatorial. Analisando esse recurso na escrita cardosiana, Lepecky afirma:

[...] o valor imagístico da palavra em Cardoso Pires só emerge à medida que todas as informações fornecidas pelo texto se recebem e verticalizam, organizando-se para produzir o próprio sentido e coadjuvar a produção do sentido de outras. A imagem resulta, assim, do emaranhado de informações justapostas e contrapostas, emaranhado que vai lentamente compondo um novo tecido. ${ }^{304}$

Nesse sentido, Cardoso Pires se vale de vários fragmentos de textos alheios para compor imagens alegóricas do poder da censura e do ditador. Segundo Patrícia Peterle,

As imagens cardosianas são construídas e perfiladas sob o fio da navalha, fragmentos, estilhaços e pedaços dispersos da sociedade portuguesa que seu olhar clínico captura. Um espaço lacunar promovido por anos de censura e de controle, no qual a literatura de Cardoso se insere com precisão e força imagética. ${ }^{305}$

O olhar de Cardoso Pires sobre os censores do Estado Novo português pôde espelhar no Reino de Mexilhões vários indicadores de controle e de censura, como a figura do morcego, por exemplo, que se atrela imediatamente à de um policial da PIDE. Portanto, nessa fábula, a trama é tecida com fios esgarçados de outras

\footnotetext{
${ }^{304}$ LEPECKI, Maria Lúcia. Ideologia e imaginário: ensaio sobre José Cardoso Pires. Lisboa: Moraes, 1977, p. 31.

${ }^{305}$ PETERLE, Patrícia. O fio da navalha. Jornal Rascunho: ensaio e resenha. Curitiba: Gazeta do Povo, n. 137, set. 2011.
} 
histórias ou fábulas e mais imagens, cujas nuanças passam a ser entrelaçadas de maneira engenhosa à fábula Dinossauro Excelentíssimo.

\subsection{A alegoria}

As palavras ouvem-se, as obras vêem-se; as palavras entram pelos ouvidos, as obras entram pelos olhos, e a nossa alma rende-se muito mais pelos olhos que pelos ouvidos. Antonio Vieira ${ }^{306}$

A palavra alegoria ${ }^{307}$ tem origem no grego allós $=$ outro + agourein $=$ falar. De acordo com Hansen, falar do outro equivale a dizer que se diz $\boldsymbol{b}$ para significar $\boldsymbol{a}$, onde $\boldsymbol{b}$ é designação concretizante e $\boldsymbol{a}$ significação abstrata; nessa relação, $\boldsymbol{a}$ e $\boldsymbol{b}$ são mantidos em correlação virtualmente aberta, possibilitando a inclusão de novos significados. Como estratégia discursiva, segundo Lausberg, a alegoria "é uma metáfora continuada"308, pode expressar-se tanto na linguagem verbal, quanto na figural ou cênica. Conforme essa concepção, ela pode ser considerada uma estratégia criativa de construção de significado, pois, partindo de dados fragmentados e concretos presentes à nossa percepção, revela o conceito ou o "ensinamento teórico que nele[a] estava contido"309. Nesse jogo de significar alguma coisa a partir de outra, cabe ao leitor "ver" o propósito oculto sob a pele das palavras, pois "os traços alegóricos são recobertos, por assim dizer, por um manto de invisibilidade" ${ }^{\text {310 }}$, assim, há a necessidade de se fazer o deciframento dos fragmentos que compõem a alegoria. Como explica Flavio Kothe, tanto a fábula quanto a alegoria revelam, a partir de um conjunto de fragmentos concretos

${ }^{306}$ VIEIRA, Antonio. Sermão, v. 1. apud PÉCORA, Antonio Alcir Bernárdez. O demônio mudo. In: NOVAES, Adauto et al. O olhar. São Paulo: Companhia das Letras, 1988, p. 304.

${ }^{307}$ Segundo Caprettini, a palavra alegoria conhece um antecedente, uponoia (de upo-noein), tendo sido registrada a passagem de uponoia a allegoria por Plutarco, nos séculos I-II d. C. A palavra uponoia corresponde à operação de conjecturar; a partir de um dado concreto presente na percepção, tratava-se de inferir a ideia ou o ensinamento teórico que nele estava contido. No entanto, tanto uponoia como allegoria foram sempre ligadas à dissimulação, ao conhecimento mediato, e aparecem, também, muitas vezes ligadas à necessidade de transmitir, de forma não imediata, uma verdade de ordem superior (CAPRETTINI, G. P. Alegoria apud CANTINHO, Maria João. $O$ anjo melancólico: ensaio sobre o conceito de alegoria na obra de Walter Benjamin. Braga: Angelus Novus, 2002, p. 57).

${ }^{308}$ LAUSBERG, Heinrich. Elementos de retórica literária, cit., p. 249.

${ }^{309}$ CAPRETTINI, G. P. Alegoria apud CANTINHO, Maria João. O anjo melancólico: ensaio sobre o conceito de alegoria na obra de Walter Benjamin, cit., p. 57.

${ }^{310}$ ROUANET, Sergio Paulo. Apresentação. In: BENJAMIN, Walter. Origem do drama barroco alemão. Trad., apres. e notas Sérgio Paulo Rouanet. São Paulo: Brasiliense, 1984, p. 215. 
e justapostos, uma ideia abstrata. Para o teórico, a fábula é uma "forma de alegoria, é uma alegoria desenvolvida. [...] Que só é abstrata no sentido de escamotear suas raízes.",311

Esta breve introdução ao conceito de alegoria remete ao capítulo em que discorremos sobre a fábula, aqui referido para completar a concepção que defendemos, de que a fábula pode ser um gênero com a característica de "dizer sem dizer", isto é, uma história que pretende simultaneamente ocultar e revelar. Do mesmo modo, tomamos a alegoria como uma estratégia para desvelar as ideias que se mantêm enraizadas nas imagens concretas sobre questões cruciais da sociedade, porém invisíveis aos olhos embotados pelo discurso oficial, por tratarse talvez de ideias e teorias que precisariam ainda ser concretizadas. Em sua narrativa, Cardoso Pires traz a voz de um contador de estórias que aborda questões abstratas que se alastravam no Reino dos Mexilhões. Ele contava à filha os conflitos existentes entre mexilhões (sobretudo os Pedintes Voadores), os DêErres (assessores do Imperador, a polícia política e os censores) e o Imperador, que viria a se transformar em um monstro jurássico e, posteriormente, ao morrer, em estátua.

Nesse Reino, a metamorfose do Imperador em Dinossauro ocorre lentamente, pois o narrador apresenta gradativamente índices que vão compondo a imagem de um ditador. Logo, nessa fábula, a imagem do Imperador parece surgir constituída de duas imagens, visto que, desde quando ele nasceu, o Regedor insistia para que aquele menino tivesse um "ofício que servisse ao divino e ao profano"312. A partir de tal colocação, percebemos, no enredo da fábula, essas duas imagens: a primeira, associada à sua pseudo-missão salvadora, imagem que ele mesmo tinha de si, de missionário, que se desdobrava na de um orientador, de um grande líder; a segunda, profana, ligada às metamorfoses que ele sofre ao longo do enredo. Portanto, a construção alegórica é feita através de livre associações entre ideia e imagem concreta, como a visão de um manipulador ou dominador de palavras que se torna um ditador, um tirano: um Tiranossauro Rex.

\footnotetext{
${ }^{311}$ KOTHE, Flávio R. A alegoria, cit., p. 12-13.

${ }^{312}$ PIRES, José Cardoso. Dinossauro Excelentíssimo, cit., p. 20.
} 
A imagem profana, por assim dizer, vem relacionada ao vício do Imperador de colecionar palavras difíceis quando ele ainda era criança. Seguindo os rastros das ações desse menino, vamos ver que ele estudou,

queimou as pestanas, amareleceu.

Ora, isto de ele se dedicar às palavras e aos raciocínios em antepassado fez com que muita boa gente pensasse que trazia alguma novidade nova. Traria? Os doutores, do alto da sua gravidade, acenavam que sim. [...]. Os próprios frades, por via de regras gente recolhida, não resistiam a erguer os olhos, embevecidos. [...]. Por fim os guerreiros-chefes, percebendo o contentamento geral: Talvez, talvez... Era muito provável que andasse ali génio de primeiríssima.

De modo que foi chamado para Imperador. ${ }^{313}$

Como vimos anteriormente, o pintor e cartunista João Abel Manta, além de ilustrar a primeira edição da fábula Dinossauro Excelentíssimo, de José Cardoso Pires, publicou em 1978 o livro Caricaturas portuguesas dos anos de Salazar, onde produziu algumas caricaturas do ditador que se aproximam daquela obra de Cardoso Pires no que se refere ao apoio que o personagem teve na fábula, semelhante ao que ocorrera com Salazar. Essas caricaturas, que Abel Manta chamou "as idades de Salazar", constam do Anexo desta tese: a primeira imagem retrata o apoio que Salazar teve dos Mestres (Figura 3), a segunda representa a união de Salazar com os militares (Figura 4) e a terceira mostra Salazar e os "padres" (Figura 5). De modo semelhante, podemos observar essas relações políticas do personagem Imperador-Dinossauro com os demais segmentos sociais, como representados na ilustração (Figura 6).

Se acompanharmos a trajetória da vida desse Imperador na fábula de Cardoso Pires, veremos que ele tende a sofisticar cada vez mais seu modo de manipular as palavras. Como exemplo disso, temos a manipulação de palavras que mudam de contexto para beneficiar o próprio Imperador; afinal, naquele Reino, "onde se via a pobreza devia-se ler modéstia" ${ }^{314}$. Quando finalmente foi chamado a assumir de vez o comando do Reino, ele "Vinha magro e iluminado de tanto estudar, mas vestido de mestre, porque o era" ${ }^{315}$. No entanto, o fato de controlar o significado das palavras ou distorcer o discurso não era suficiente para esse falso profeta, mestre ou messias, pois ele sabia que, "Tendo sido doutor entre os

\footnotetext{
${ }^{313}$ PIRES, José Cardoso. Dinossauro Excelentíssimo, cit., p. 37 (grifo nosso).

${ }^{314}$ Ibid., p. 46.

${ }^{315}$ PIRES, José Cardoso. Dinossauro Excelentíssimo, cit., p. 48
} 
doutores, a sua especialidade era as palavras" ${ }^{, 316}$. De repente, as palavras começaram a sair do seu controle, o que o motivou a criar um plano para dominálas. O Imperador passou a considerá-las como inimigas e lutou com elas até a sua morte. Foi durante esse período de instabilidade para o Imperador, ou da possível perda da censura das palavras, que ele inventou a câmara de torturar palavras, porque pretendia limpar o veneno que acreditava estar envolto na pele das palavras, onde parecia haver significados fantasmas habitando-as. Após esse invento, o Imperador se dedicou com afinco a perseguir as palavras, mas, curiosamente, seria "na cegueira de perseguir as palavras, [que] Sua alteza iria cair ${ }^{\prime 317}$.

Em certo instante da narrativa, os súditos do Imperador deixaram de ouvilo; foi quando ele se atirou "com raiva dobrada às palavras"318. Desse embate, encoberto pelo véu da metáfora, percebemos que foram as palavras que o conduziram ao trono, funcionando como promessa de esperança no futuro. Esse "messias", que, com o uso das palavras, poderia libertar o reino da fome e da miséria, vê nela uma inimiga, pois essa mesma palavra que ele tanto desejava limpar era utilizada por seus opositores e, paradoxalmente, poderia matar com seu "veneno" o sonho do ditador. Por causa dessa obsessão, o Imperador iniciou um processo de desumanização para tornar-se um animal, um Dinossauro, um monstro manipulador da palavra (Anexo - Figura 8). O narrador vai construindo essa imagem ao longo do enredo, revelando pequenos detalhes sobre as etapas da metamorfose do Imperador em Dinossauro. Não podemos deixar de perceber que esses traços, aparentemente encobertos, estão relacionados às ações do Imperador como mestre, até culminar com a imagem mais impactante da fábula, que é a do "monstro da sapiência", um dinossauro:

Tempos depois quem visse os dois Imperadores lado a lado, o de bronze e o do rosto de cera, perceberia os desgastes que os anos tinham trazido. Dobrado à secretária anos a fio, o Mestre criara bossas nas costas e como escrevia em largos comprimentos de onda para alô-mundos, murmurando as palavras, roendo-as ao correr da caneta, os lábios foram desaparecendo, sugados. A boca ficou em ferida, os dentes em escama - um bicho.

"JESUS, COMO TU MUDASTE"

\footnotetext{
${ }^{316}$ Ibid., p. 50.

${ }^{317}$ Ibid., p. 93.

${ }^{318}$ Loc. cit.
} 
diria a mãe se fosse viva. ${ }^{319}$

[...] Também a mão direita, essa que na estátua aparecia serena e purificada como a dos bispos, também a mão estava destruída, percebia-se agora. Tinha ganho uma data de calos, nós da caneta; os dedos afilaram-se em garra e acabou por não ser mão nem ser nada mais um molho de raízes penduradas na extremidade de um braço que lhe dava pelos joelhos. Só os olhos continuavam vivos, treinadíssimos em espreitar segundos sentidos, dois carvões de diamante. ${ }^{320}$

[...] Surge-nos assim o Mestre, a crescer e a libertar-se da forma humana. Monstro de sapiência que avançava sobre planícies desoladas, sobre mundos por construir, cinza, água e metal, com o dorso eriçado e a temível majestade dos bichos da primeira criação. Alguém lhe chamou Dinossauro - e ficou. ${ }^{321}$

Essa figura enigmática do Imperador, personagem de Dinossauro Excelentíssimo que se metamorfoseia em dinossauro, foi ilustrada por Abel Manta (Anexo - Figura 9) e inserida na narrativa em sua primeira edição.

Opondo-se à ideia de decomposição do corpo do Imperador, corrupção ou estrago, há um Imperador em forma de estátua que não se deteriorou e aparece na narrativa como seu irmão de bronze, caracterizado com o rosto ainda jovem. $\mathrm{Na}$ fábula, essa estátua de bronze ganha um caráter simbólico ${ }^{322}$, o de representar a ideia de domínio, de poder sobre o Reino, pois ele já não podia governar, devido aos problemas de saúde. Por orientação de seus assessores, ele deixou uma imagem à sua semelhança para garantir a manutenção do poder simbolicamente em suas mãos, isto é, para provocar o mesmo "respeito" obtido ao longo de todo o regime ditatorial por ele exercido, ou para manter vivo o medo já incorporado

${ }^{319}$ PIRES, José Cardoso. Dinossauro Excelentíssimo, cit., p. 98.

${ }^{320}$ Ibid., p. 98-99.

${ }^{321}$ Ibid., p. 100 (grifo nosso).

${ }^{322}$ Pécora, em artigo que trata da estética do olhar, cita um Sermão do Padre Antonio Vieira que procura explicar a função das estátuas para a humanidade, uma vez que o desejo de ser visto perdura mesmo após a morte. Antonio Vieira afirma: "A falsificação do real, a criação de uma imagem externa, mas sem ser, relativa sobretudo à paixão individual ainda é, entretanto, uma descrição genérica do que Vieira entende pela ação demoníaca do olhar. Não aí, pelos menos, os seus contornos mais preciosos." Na verdade, como Vieira diz em vários de seus sermões, o 'ver, regido pela paixão, encontra seu grau mais radical - isto quer dizer, mais radicalmente infeso à verdade - naquilo que ele chama de 'apetite de ser visto', o mais arraigado dos desejos do homem. Em um sermão de 1673, pregado em Roma, [...] Vieira diz justamente o seguinte: "O uso de ver tem fim com a vida, o apetite de ser visto não acaba com a morte. Esta foi a origem das estátuas romanas sepulcrais. Punha-se a estátua e imagem do defunto sobre o sepulcro, para que o homem que dentro dele não podia ver, sobre ele fosse visto. Já que faltava vida própria, ao menos não me falte a vista alheia. De maneira que, devendo os mármores da sepultura ser uns espelhos em que se vissem os vivos, são uma antecipada ressurreição da arte em que se vêem os defuntos. Tão imortal é nos mortais o desejo de ser visto.' Esse desejo maior que a vida, para Vieira, é o mesmo que dissimula sob todo desejo de ver, o mesmo que estaria na origem e no limite do olhar arbitrário do real, como descobrimento a Deus" (VIEIRA, Antonio. Sermão da quinta terça-feira da quaresma, v. 5 apud PÉCORA, Antonio Alcir Bernárdez. O demônio mudo, cit., p. 308). 
pelo povo e não permitir a troca de lugar do poder, evitando mudanças radicais ou movimentos revolucionários no Reino. Ainda, afirma Cardoso Pires:

[...] por mais compassiva que seja a nossa recordação, o dinossauro existiu. Há vestígios dele, sinais fósseis e tabelas zoométricas que permitem reconstituir a sua maneira de estar e a sua própria extinção. Hoje, verdade seja, é quase um animal mitológico, uma imagem do universo onde o homem não podia ter lugar.

Assim também o Excelentíssimo da minha estória. De personagem tumular ele regressa a esta narrativa ao sabor dos ecos, dos caprichos e das liberdades de que fui capaz para representar um cosmo conceptual tão adverso da medida humana que só podia ser contado em termos "fabulares". Dinossauro: o nome vem das associações imagéticas que este exemplar comporta. ${ }^{323}$

Os elementos que concretizam essa ideia de ditador passam pelo processo de associação entre as atividades do torturador de palavras e a figura do Dinossauro, referindo-se o narrador a um monstro sanguinário e terrível. Essa imagem alegórica é recurso presente para a concepção do ditador, porque essa metamorfose é percebida claramente no corpo do personagem, principalmente nas costas, nos lábios, nas mãos e nos dedos. Finalmente, o Imperador se transforma em Dinossauro, pois através da metamorfose passa de humilde mexilhão(camponês) para poderoso Dinossauro(Imperador), a um animal feroz, que devora e massacra tudo o que se opõe a ele. Após a metamorfose, o Imperador, obcecado em devorar palavras, sofre um acidente no gabinete da câmara de torturar palavras, e isso gera um tumulto no Reino, quando o então Dinossauro permanece em estado de coma por um bom tempo. Ao acordar,

Douktor Dinosaurus se mostrava saudável e devorador como nunca (devorador de palavras, deduzia-se), orgulhoso a mais não poder ser (estava-lhe na massa do sangue, o orgulho) e decidido - do gênero doa a que doer. ${ }^{324}$

\section{E finalmente o Dinossauro veio a falecer.}

Reza a História que Dinossauro Um faleceu a tantos de tal, hora da Comarca dos Doutores, fulminado por uma síncope de amnésia. A dado instante esqueceu-se que estava vivo e pronto. Faleceu.

Os mexilhões comuns quando foram espreitar à urna de cristal abanaram a cabeça: acharam-no demasiadamente igual ao retrato para ser verdade. ( $\mathrm{E}$ assim, funcionavam ao contrário do antigo Guarda-Mor que não quis o mestre com cara de Dinossauro; mas era de esperar, os mexilhões sempre foram e continuariam a ser espíritos de contradição...). Mais tarde, como o corpo estivesse exposto ao

\footnotetext{
${ }^{323}$ PIRES, José Cardoso. Post-scriptum. In: O burro em pé, cit., p. 118-119.

${ }^{324}$ PIRES, José Cardoso. Dinossauro Excelentíssimo, cit., p. 137.
} 
Reino por longos dias, os mesmo mexilhões debruçaram-se mais demoradamente sobre ele, rosnando pelo canto da boca (pareciam conspiradores) e fazendo olhares entendidos. Ninguém lhes tirava aquela da cabeça: o Imperador tinha sido trocado. O que ali viam era uma máscara, nunca um homem que contava dezenas de anos sobre a imagem do retrato oficial séculos, talvez. Viraram as costas, chateados como perus. ${ }^{325}$

$\mathrm{Na}$ cena descrita, podemos perceber a ironia do narrador em demonstrar algumas situações que estão ligadas aos ditadores de modo geral. O Imperador entra em coma, fica sem memória e tem como causa da morte uma sincope de amnésia, pois se esqueceu de que estava vivo e morreu. Parece dar a entender que ele foi assassinado, o que, às vezes, acontece realmente com os ditadores. Do mesmo modo, através da ironia e do sarcasmo, o narrador relata o ritual de morte: velório e sepultamento com direito a despedida da população, que "venera" os grandes ditadores.

Houve novo tumulto no Reino, o Imperador-Dinossauro não era reconhecido pelos súditos, pairava no ar uma dúvida em relação à sua morte, pois a imagem que os súditos viam na urna mortuária não coincidia com a idade que os mexilhões acreditavam que o "Excelentíssimo" deveria ter.

Contemplavam o cadáver sem idade, as faces correctas e lisas, esse irmão misterioso trazido para ali como demonstração de uma morte sagrada.

[...] situação estranha, aquela: beatas e mexilhões encontravam-se, sem o saberem, em posição semelhante porque, quer elas, quer eles, interpretavam o cadáver do Imperador como uma negação do homem real - ou não seria assim? Mistério de santidade para umas, mistério de palácio para outros, de mistério é que não se passava.

[...] Prudência, deve ter sido atitude dos notáveis mais Dê-Erres. Nada melhor deixar correr, porque na Comarca dos Doutores vozes de mexilhões não chegam ao céu. Basta ver como, considerando-se teimosamente cidadãos (cidadãos, calculese) e à margem, continuavam ferrados na rocha, e na deles: jurando de pé juntos que o Excelentíssimo estava vivo. ${ }^{326}$

A "morte sagrada" do Imperador antes referida e o aparecimento de uma nova imagem, misteriosa, a de um "cadáver sem idade", levantam questões relacionadas à imagem do poder na fábula, pois, sendo o Dinossauro seu representante concreto, perde essa imagem ao morrer, uma vez que ele não é reconhecido pelo povo. Entendemos que esse fato é enfatizado para demonstrar

\footnotetext{
${ }^{325}$ PIRES, José Cardoso. Dinossauro Excelentíssimo, cit., p. 143.

${ }^{326}$ Ibid., p. 145-147.
} 
que o poder não tem rosto, pois, com a morte, parece haver um retorno, isto é, o poder gira em círculos, e o rosto é sempre um mistério. Portanto, percebemos que há uma superposição de imagens, em que a imagem alegórica do ImperadorDinossauro está contida na imagem do ditador metamorfoseado em dinossauro. Essa imagem se concretiza em virtude das consequências das ações do ImperadorDinossauro, sobretudo os atos opressores que caracterizam seu regime de governo.

Esse episódio, que se refere também à aparência do Imperador-Dinossauro, nos faz resgatar a imagem que ilustra a capa da primeira edição de Dinossauro Excelentíssimo, criada por João Abel Manta (Anexo - Figura 10). Nela, o ilustrador dispõe elementos metafóricos que delineiam um animal, o que nos leva a imaginá-lo como um "emblema" 327 composto de três partes: o título, a imagem e o texto, de modo que a imagem detém em seu processo criativo a associação metonímica do todo em partes. Na imagem constante da capa do livro, visualizamos as possíveis associações dos fragmentos que constituem a figura de um soberano - a coroa, característica do poder político do Imperador; o manto dourado, o poder econômico; a cauda de um dinossauro, o poder atemporal. A esses elementos, acrescenta-se o título Dinossauro Excelentíssimo. Conforme nossa leitura da capa e considerando o objeto, que é o livro de José Cardoso Pires, temos o conteúdo: a fábula, com todos os elementos a ela associados. Afinal, trata-se de uma narrativa alegórica, que procura demonstrar, através das associações imagéticas percebidas nas entrelinhas das descrições, a face concreta dessa ficção que aborda um tema social e político, cuja imagem principal é a de um ditador que impõe o poder e a censura ao Reino dos Mexilhões.

No entanto, a ilustração da capa da primeira edição dessa fábula, produzida por Abel Manta, chama a nossa atenção pelo fato de que, no lugar do rosto de um

\footnotetext{
${ }^{327}$ Segundo Hansen, "o emblema [...], pintam-se como partes de imagens sinédoques - uma coluna pelo edifício, uma espada pelo guerreiro, um ramo pela árvore - que a convenção da época prescreve como metáfora ou alegoria visual ("imagem") de um conceito: a coluna pela força, a espada pela oratória, o ramo pela vida etc. Ao mesmo tempo, o emblema [...] utiliza palavras relacionadas diretamente ou indiretamente com a imagem pictórica, traduzindo-a ou remetendoa para outro campo nocional. A alegoria se dá, no caso, como alegoria da alegoria, pois faz a relação interpretante de imagem e sentença: é performativa, feita para o leitor/espectador supostamente capaz de fazer a relação de imagem e palavra e sua tradução" (HANSEN, João Adolfo. Alegoria: construção e interpretação da metáfora, cit., p. 191). Ou ainda: o emblema é uma forma "alegórica constando de corpo (imagem) e alma (discurso) [...]. Seu uso é público e geralmente tem finalidade político-moral" (Ibid., p. 226).
} 
rei, tem-se o título, Dinossauro Excelentíssimo, como a evidenciar uma lacuna a ser preenchida. Só após a leitura de toda a história entendemos essa mensagem, posto que, ao final, o poder é representado como uma máscara. O poder é onipresente e apresenta-se sob várias máscaras, que são sobrepostas de modo a deixar um rosto sem identidade, um vazio, o que justifica o espaço vazio da imagem, mas traz, arraigados a essas máscaras, alguns elementos que, organizados alegoricamente, concretizam a ideia de poder. Por isso, é possível pensarmos que há implícito, nessa fábula, um tratado sobre o exercício do poder e o modo como ele pode se configurar em contextos ditatoriais.

"O DA MÁSCARA",

como lhe chamavam os mexilhões, apontando as mil e uma estátuas de parque-eavenida donde o Douktor Dinossaurus, bem no alto, estendia um olhar gelado sobre o mundo. ${ }^{328}$

No Reino do Excelentíssimo, em particular, trata-se de figurar alegoricamente a imagem do dinossauro, que pode ser associada a um monstro do poder, em que se inscreve a própria história do Estado Novo de Portugal.

Entendemos, portanto, que essas metamorfoses sofridas pelo personagem são intencionais, pois Cardoso Pires se utiliza da estratégia de juntar vários fragmentos para compor a imagem de um ditador do século XX. Para isso, revê a História da humanidade, desde seus primórdios, até chegar a configurar, em certo momento, as faces de um ditador. Ele faz uso de uma linguagem alegórica, demonstrando que de uma imagem concreta se cria uma ideia; mostra como o poder é representado, com toda a sua majestade, mas sugerindo que ele pode também ruir; afinal, o Imperador-Dinossauro termina sua trajetória política entre ruínas. Além disso, nessa fábula, não há uma moral explicita, pois a moral acaba diluindo-se ao longo do enredo. A narrativa sugere, desde o início, que o menino seria um predestinado: messias, salvador, redentor; mas o Imperador passa por metamorfoses físicas, sociais e morais ao longo da fábula, a moral parece ser as metamorfoses desse menino em messias, missionário, advogado, militar, Imperador (estátua de bronze) e dinossauro.

\footnotetext{
${ }^{328}$ PIRES, José Cardoso. Dinossauro Excelentíssimo, cit., p. 147.
} 


\subsection{A configuração do poder}

O poder, na fábula Dinossauro Excelentíssimo, se concretiza em uma imagem sem rosto, transfigurada por máscaras que mudam conforme a necessidade do Reino. Paralelo a essa imagem, configura-se outro nível da rede do poder, que impulsiona os acontecimentos retratados na narrativa, percebidos a partir dos comportamentos dos personagens: são "caricaturas" de autoridades, que vivem ao redor de um poder central e se denominam conforme o lugar que ocupam dentro desse estilhaçado complexo que é o poder. Segundo Cunha ${ }^{329}$, são perceptíveis na fábula alguns núcleos de poderes que se organizam conforme o objetivo e a função que os personagens desempenham no enredo. Não podemos nos esquecer, no entanto, de que o poder central, mas não absoluto, está nas mãos do Imperador.

O primeiro núcleo de poder é composto pelos personagens da elite rural (madrinha, padre e regedor); ficou a cargo desse núcleo escolher um líder para manter o Reino em ordem. O objetivo dessa iniciativa foi enviar um camponês para a cidade a fim de cumprir o seu destino de participar do governo central. Assim, a elite poderia perpetuar seu poder ${ }^{330}$. É nesse núcleo que o jogo político se configura por meio de uma teia, em que seus integrantes promovem as negociações entre o público e o privado, entre grupos e instituições:

Leis, decidiu o padre local [...] O regedor [...] disse que na espada é que estava o mando e a justiça [...] Dona Madrinha [...] [que] Ouviu falar em espadas, em guerreiros, e nem esperou por mais nada; abriu os braços de contentamento pronunciando estas palavras [...]: "QUE PERFEITO MISSIONÁRIO!" 331

Os Dê-Erres são os personagens que representam o segundo núcleo de poder, com a função de conter as revoluções dos mexilhões insubmissos, além de

${ }^{329}$ Cf. CUNHA, Helenice. A trama de poder em Dinossauro Excelentíssimo. In: SALEM, Khalil (Org.). Conhecimento, tecnologia e linguagem. São Paulo: Fiuza, 2013. Coletânea Acadêmica de Estudos em Letras e Educação (CAELE), n. 12.

${ }^{330}$ Sabemos que foi característica do governo de Salazar o apoiar-se nos "poderes paralelos". Salazar "[...] tinha enraizado suficientemente o seu regime nas realidades sociais portuguesas para garantir algum apoio popular. A igreja e os pequenos proprietários rurais [...] o mesmo faziam os latifundiários" (MAXWELL, Kenneth. A construção da democracia em Portugal, cit., p. 33).

${ }^{331}$ PIRES, José Cardoso. Dinossauro Excelentíssimo, p. 19-20. 
promoverem o Imperador. Como eles detêm o saber do Reino dos Mexilhões, são considerados guardiões; assim, seus poderes parecem vir desse estatuto:

Cada qual empunhava seu bastão de igreja [...]; e à maneira de mitra tinha sobre os joelhos um chapéu conhecido por capelo que só cabe na cabeça dos muito sabedores e não na de qualquer dos estudantes que circulavam cá em baixo, decorando a sebenta. ${ }^{332}$

Os mexilhões Pedintes Voadores formam o terceiro núcleo de poder; nele, encontram-se os mexilhões descontentes, considerados subversivos pelo Imperador porque tentam desmascarar o discurso manipulador do Estado. Eles se colocam à margem do estado ditatorial, criam um discurso contestador para se contrapor ao discurso manipulador do Imperador: "E então os mexilhões, muito bem calados, pensaram: [...] Foi a partir daí que começaram a correr certos ditados de ocasião, só para governo dos mexilhões, naturalmente, e que não faziam o menor sentido a não ser para eles." 333

Portanto, é evidente que, na fábula, vários núcleos de poderes se instauram. Como explica Foucault, não existe relação de poder sem resistência, porque as lutas de contrapoder ocorrem dentro do próprio núcleo do poder "local". Os conflitos são vários, como o são também os focos que se organizam no interior da rede, de modo que existem núcleos de poderes atuando mutuamente, ou opondose, como fazem os mexilhões Pedintes Voadores, ou apoiando o Imperador, como fazem os Dê-Erres. Roberto Machado, ao analisar a questão do poder na obra de Foucault, conclui:

O interessante da análise é justamente que os poderes não estão localizados em nenhum ponto específico da estrutura social. Funcionam como uma rede de dispositivos ou mecanismos a que nada ou ninguém escapa, a que não existe exterior possível, limite ou fronteiras. Daí a importante e polêmica idéia de que o poder não é algo que se detém como uma coisa, como uma propriedade, que se possui ou não. Não existe de um lado os que têm o poder e de outro aqueles que se encontram alijados. Rigorosamente falando, o poder não existe; existem sim práticas ou relações de poder. ${ }^{334}$

Esse conceito pode explicar porque na fábula surge outro discurso que se contrapõe ao do Imperador: o discurso dos mexilhões Pedintes Voadores. Embora

\footnotetext{
${ }^{332}$ PIRES, José Cardoso. Dinossauro Excelentíssimo, cit., p. 36.

333 Ibid., p. 49.

${ }^{334}$ FOUCAULT, Michel. Microfísica do poder, cit., p. XIV.
} 
se contrapondo, essa fala do oprimido atua com os mesmos métodos e na mesma esfera de poder do Imperador, ou seja, utiliza elementos que envolvem a dissimulação tanto da fala quanto da escrita. Nessa fábula, temos duas forças que se opõem - mais precisamente, dois discursos opacos que se tensionam: o discurso dos Dê-Erres e o discurso dos mexilhões Pedintes Voadores.

DECLARA-SE A INVASÃO DOS DE-ÊRRES

"AO ATAQUE!"

[...] Apanhados de costas, os da beira-mar renderam-se sem discussão, tanto mais que não compreendiam a língua dos invasores. [...] Os dê-erres triunfantes, repetindo a sebenta dos treinadores, lhes davam o golpe de misericórdia com rajadas de discursos. Discursos e contra-discursos, discursos por uma pá velha como só os dê-erres sabem fazer. ${ }^{335}$

Porém, contrapondo-se aos discursos dos assessores, os doutores do Imperador-Dinossauro, eis que: "NA PARADA DOS DOUTORES APARECEM OS PEDINTES VOADORES." 336

\section{Enfim,}

[...] já que o Reino era pobre o Imperador iria enriquecê-lo com palavras das melhores origens e criar uma linguagem geral que unisse o jovem ao velho, o rico ao necessitado, o mexilhão ao dê-erre. ${ }^{337}$

As ações dos personagens concretizam a imagem de um poder que revela, através do uso da palavra, a luta silenciosa, travada entre os mexilhões Pedintes Voadores e os doutores, para ocupar o espaço central do poder. Por isso, enquanto o Imperador cassa a palavra "dessa malta", os mexilhões criam um código próprio para fugir de sua perseguição.

E cá viemos dar às palavras. Como sempre. "Com palavras e moscas povoa-se o reino", rosnavam os mexilhões descontentes, os Pedintes Voadores. Mas o Imperador acabava com o pio dessa malta, destruindo diariamente uma boa porção delas. Queria desempestar o Império e as consciências queimando o termo grosseiro e a frase manhosa, e aí conseguindo. Em menos de um fósforo os dicionários estavam no nervo, rapados, e os mexilhões a falar praticamente por sinais. ${ }^{338}$

\footnotetext{
${ }^{335}$ PIRES, José Cardoso. Dinossauro Excelentíssimo, cit., p. 43-44.

${ }^{336}$ Ibid., p. 48-49.

337 Ibid., p. 51.

${ }^{338}$ PIRES, José Cardoso. Dinossauro Excelentíssimo, cit., p. 72.
} 
De acordo com Michel Foucault, o poder "circula [...] funciona em cadeia [...] se exerce em rede" 339 . Considerando essa dinâmica do exercício do poder, compreendemos que o poder circula por toda a sociedade, em diferentes esferas da vida social, concretizando-se na imagem de uma teia. Na fábula, essa circulação acontece na sequência em que surgem - sempre tendo como centro a figura do Imperador - o padre, o regedor, a madrinha, os Dê-Erres mestres, os Dê-Erres conselheiros e, finalmente, os mexilhões Pedintes Voadores. A distribuição da competência quanto ao exercício de poder está alegórica e metaforicamente representada em várias ações dos personagens, pois o poder é o mecanismo propulsor da fábula. Para Foucault, não há “diferença de natureza entre o poder que exerce um reles tira e o poder que exerce um ministro"340, e essas palavras podem também se aplicar à ficção de Cardoso Pires porque o mesmo pode ser dito a respeito da natureza dos poderes exercidos no Reino dos Mexilhões, onde

Conforme a pessoa, assim se escolhia a chave que lhe dava entrada na torre. Parece que com o andar dos tempos os conselheiros arranjaram também as suas chaves para receber os cavalheiros abaixo deles. Estes fizeram o mesmo em relação aos mais abaixo que, por sua vez, inventaram logo outras chaves para os ainda mais abaixo, e nesta cegarrega - chave que abre a chave da chave - até os contínuos de repartição, eternamente a bocejar e a olhar as horas, tinham as suas chaves minúsculas que nem por isso deixavam de ser úteis.

O Reino desdobrava-se num imenso arquivo de gavetas a abrirem-se umas às outras. $^{341}$

Toda uma hierarquia de poderes pode ser identificada em diversas chaves que se desdobram sucessivamente em outras. Cria-se um longo caminho de negociações que dependem das chaves do Reino, e, à revelia do Imperador, instaura-se um poder paralelo. Essa imagem vem confirmar a ideia de que o poder não se encontra nas mãos de uma única pessoa, mas circula na malha social. Paralela a essa organização, há outra estrutura que está baseada no grau do aparente exercício de poder que detém dentro da escala social, e, nessa escala, o Imperador ocupa o primeiro lugar, representando o poder absoluto: "no Reino só

\footnotetext{
${ }^{339}$ FOUCAULT, Michel. Soberania e disciplina. In: Microfísica do poder, cit., p. 183.

${ }^{340}$ FOUCAULT, Michel. Os intelectuais e o poder. In:

${ }^{341}$ PIRES, José Cardoso. Dinossauro Excelentíssimo, cit., p. 71. 
havia 1-Único Mestre que tudo podia e tudo lo mandava," ${ }^{342}$; já os Dê-Erres estão na segunda posição, pertencem à classe dos doutores dominantes, composta por políticos, burocratas, mestres, policiais, padres, etc., que são os responsáveis pela movimentação da engrenagem burocrática do Reino. Embora estes não possam tomar decisões, iludem-se pensando o contrário: "cada dê-erre pretendia enganar os outros fingindo que era o mais importante logo a seguir ao Chefe" ${ }^{\text {"343; }}$; em terceiro lugar estão os mexilhões, que representam a classe trabalhadora: o mexilhão é um indivíduo que se assemelha a uma "criatura à margem, mirrada, [...] tem a ciência certa dos anônimos: pensa e não fala, vai por si" ${ }^{344}$. Nessa terceira classe, ressaltamos os mexilhões descontentes, Pedintes Voadores, que têm a função de questionar a ordem do Reino, e para isso criam um código secreto para se comunicarem. Foram eles que espalharam "certos ditados de ocasião, só para governo dos mexilhões, naturalmente, e que não faziam o menor sentido a não ser para eles.",345

\subsubsection{O poder do Dinossauro Excelentíssimo}

O personagem Dinossauro Excelentíssimo é um déspota que procura sempre manter o Reino livre de todo e qualquer discurso que desestabilize a ordem por ele imposta. Para isso, ele passa a fazer uso de sua autoridade e do saber, sobretudo o de manipular as palavras. Acreditamos ser esse o recurso encontrado pelo poder para deter o conhecimento (saber) que circulava na rede de poder social. O saber que se acerca do reino está concentrado nas mãos dos Dê-Erres, os quais "por causa da sabedoria [...] apresentavam um aspecto de fria gravidade" ${ }^{\text {346 }}$. Através de sua aparência sisuda, os Dê-Erres praticavam o exercício do poder e procuravam manter sua autoridade com a finalidade de manter os "rebanhos de desorientados" em ordem. Mas esses mestres escolheram, entre todos os mexilhões, apenas um deles para transmitir esse saber; elegeram o pequeno camponês porque

\footnotetext{
${ }^{342}$ PIRES, José Cardoso. Dinossauro Excelentíssimo, cit., p. 62.

${ }^{343}$ Ibid., p. 70.

${ }^{344}$ Ibid., p. 42.

${ }^{345}$ Ibid., p. 49.

${ }^{346}$ Ibid., p. 45.
} 
perceberam que ele tinha o "vício de colecionar palavras"347 e sabiam que esse pequeno, instruído, seria capaz de disseminar o saber pelo Reino. Destacamos, mais uma vez, a habilidade daquele menino em manipular a palavra, pois seu dom foi reconhecido pelos doutores da capital de tal maneira que ele acabou sendo chamado pela cúpula política do reino:

Os doutores, do alto da sua gravidade, acenavam que sim: tratava-se de um falar muito próximo dos alfarrábios por onde tinham estudado - logo, o mais perfeito. Juízes e escrivães, idem. Habituados a pentear parágrafos e alíneas, gostavam daquela maneira de discorrer tão encarreirada a aparo burocrático. ${ }^{348}$

Observamos que a organização da rede de poder, nessa fábula do Excelentíssimo, tem como base a capacidade de saber como manipular palavras, para ler, interpretar, compreender, analisar, criar discursos, - enfim, inventar "realidades". Essa capacidade pode ser encontrada no desejo do Imperador de cassar algumas palavras, com a intenção de desviar significados que poderiam prejudicar a paz do Reino. Portanto, é por meio do saber que o Imperador exercia a autoridade que lhe foi outorgada para comandar o Reino.

No entanto, apenas saber fazer algumas alterações esporádicas não satisfazia à fome do Imperador-Dinossauro; ele procurou reunir saber e autoridade para promover o silêncio no Reino, a fim de calar as vozes insubmissas. Através desses elementos (saber - poder - silêncio), o grande ditador passou a desarticular a estrutura sintática, com o objetivo de dificultar a compreensão do discurso e de desvirtuar conceitos, o que é "ao mesmo tempo visível e invisível, presente e oculto, investido em toda parte" ${ }^{349}$, isto é, o poder permeado em todo tipo de relação.

Outra estratégia do uso do saber, na fábula, está metaforicamente representada no ato de abrir portas. É preciso aguçar a capacidade de ler as entrelinhas e de desvendar as imagens ocultas nas "chaves" dos significados: saber a senha, ou a chave certa para entrar na narrativa e conseguir desvendá-la, porque esse reino "desdobrava-se num imenso arquivo de gavetas a abrirem-se umas às outras" ${ }^{, 350}$. Como vimos, a partir das ações do Imperador, o contador de

\footnotetext{
${ }^{347}$ PIRES, José Cardoso. Dinossauro Excelentíssimo, cit., p. 22.

348 Ibid., p. 37.

${ }^{349}$ MACHADO, Roberto. Introdução. In: FOUCAULT, Michel. Microfísica do poder, cit., p. 75.

${ }^{350}$ PIRES, José Cardoso. Dinossauro Excelentíssimo, cit., p. 71.
} 
estória nos conduz a uma reflexão acerca do modo como a rede de poder discursivo se manifesta. Concluímos que essa rede é elaborada com pequenos discursos que, ao se entretecerem, criam uma teia sociopolítica na qual se encontram os métodos com os quais os "ditadores" divulgam seus discursos opacos, com a intenção de se perpetuarem.

Na fábula Dinossauro Excelentíssimo, a imagem do ditador se configura a partir dos atos despóticos com os quais o Imperador-Dinossauro impõe aos mexilhões a sua autoridade. Para exercer e manter o poder, o Imperador estabeleceu mecanismos repressivos capazes de "devorar" as palavras que fugissem à ideia obsessiva de ordem. Como já referido, para pôr em prática suas estratégias, ele criou uma "câmara de torturar palavras", com a função de caçar e cassar nas palavras os significados venenosos que pudessem vir a destruir sua prática repressora ${ }^{351}$. Portanto, “agora que estava sentado a governar começou a magicar um plano para pôr o Reino a falar numa língua limpa e severa, em que todos se entendessem.",352

Com essa prática, o Imperador-Dinossauro manipulava discursos para atingir finalmente seu desejo, o de homogeneizar as ideias, colocando-as numa sintaxe que somente ele e os Dê-Erres compreendiam. Ele atingia seu objetivo, porque, quando ia discursar em praça pública, a população não o entendia, apenas o escutava, de modo que

[...] os peregrinos esticavam o pescoço a procurar seguir-lhe o rastro pelos caprichos das alturas. Percebiam e não percebiam, pouca coisa, quase nada, dados os seus fracos entendimentos do dialecto dê-erre, mas não era motivo para se afligirem: iriam compreender quando o padre e a professora Minha-Senhora os reunissem lá na aldeia para fazerem o comentário próprio. Aí seria o Discurso em tradução livre [...]

"APOIADO!"

"VIVA O IMPERADOR!"353

No trecho citado, percebemos que os mexilhões "peregrinos" tentavam, mas não conseguiam entender aquela língua que o Imperador-Dinossauro passara tanto tempo para depurar; notamos também que eles esperavam que o padre e a

\footnotetext{
${ }^{351}$ Cf. CUNHA, Helenice. A rede de palavras e a máscara de Imperador em Dinossauro Excelentíssimo, cit.

${ }^{352}$ FOUCAULT, Michel. Microfísica do poder, cit., p. 51.

${ }^{353}$ PIRES, José Cardoso. Dinossauro Excelentíssimo, cit., p. 82-83.
} 
professora "Minha-Senhora" fizessem uma tradução livre. Nesse episódio podemos perceber a fina ironia do autor, visto que sua tentativa de criar uma só língua não tem sucesso, já que ela precisa ser traduzida, precisa ser mediada por outras pessoas que dominam a linguagem criada pelo Imperador. Percebemos também que, nesse ato de traduzir, o Imperador também perde o controle sobre o discurso, e perde o discurso para instituições que de certa maneira dominam o saber: a igreja e os mestres-doutores. Desse modo,

[...] o discurso do Imperador é incompreendido pela 'massa' por isso, necessita de um 'discurso tradutor'; mas a tradução, por sua vez, torna-se um discurso livre na 'imaginação' dos peregrinos. Concluímos assim que o discurso do Imperador acaba se perdendo ao longo das traduções. Logo, compreendemos que o Imperador, ao manipular as palavras para falar sobre o Reino, cria uma 'ficção'. Do mesmo modo, os peregrinos constroem outra 'imagem' dos discursos do Imperador. Vivese, portanto, em um Reino fictício, como se a comunicação se fizesse por meio de um colóquio de espelhos. ${ }^{354}$

Esse entrelaçamento de significados desenha a imagem de uma teia que configura o poder através da linguagem no Reino dos Mexilhões. Nesse sentido, Foucault esclarece que o poder é alterado continuamente, a cada instante e a cada evento, e tem a função de construir e destruir fatos, porque, ao produzir outras versões, transforma, acrescenta, rasura discursos com os quais mantém estreita relação para compor uma rede plural e infinita de atos que tecem com sua dinâmica. Portanto, "o que faz com que o poder se mantenha, e que seja aceito, é simplesmente que ele não pesa só como força que diz não, mas que de fato ele permeia, produz coisas, induz ao prazer, forma saber, produz discurso."355

$\mathrm{Na}$ fábula, é assim que o Imperador-Dinossauro tenta controlar as palavras que circulam pelo Reino; porém, ele não obtém êxito. Ocorre que, assim como ele faz uso do discurso, de um saber, para exercer a autoridade, os mexilhões Pedintes Voadores vão também produzir discursos e constituir um saber próprio a fim de libertar o Reino dos Mexilhões de seu caçador mais feroz: o ditador dinossauro.

${ }^{354}$ CUNHA, Helenice. A rede de palavras e a máscara de Imperador em Dinossauro Excelentíssimo, cit., p. 88.

${ }^{355}$ FOUCAULT, Michel. Verdade e poder. In: Microfísica do poder, cit., p. 8 (grifo nosso). 


\section{INTELECTUAL: “UM ANIMAL INCÓMODO”}

Uma Inquisição nunca se faz isolada, tem mil olhos e mil ouvidos, e mil caminhos para o silêncio.

José Cardoso Pires ${ }^{356}$

Em Dinossauro Excelentíssimo, assim como fica evidente a manipulação da palavra pelo ditador, há, como observamos no capítulo anterior, a presença em ausência, isto é, a atuação dos mexilhões denominados Pedintes Voadores fica implícita na obra, eles surgem sempre como contrários ao sistema vigente a ponto de criar uma linguagem da qual só eles sabiam os significados. E o representante máximo desses mexilhões insatisfeito é um narrador, um contador de histórias, que, como mexilhão precavido, busca transmitir a todos um saber que pode ser ocultado pela poeira da História, mas que ele registra para que não seja esquecido. Afirma o próprio Cardoso Pires, relacionando seu texto à ditadura do Estado Novo:

Ao escrever esta fábula (fábula porque se passa no tempo em que os animais falavam e os homens sufocavam), eu sabia que a memória política é frágil; que se conta com isso para repetir o erro histórico e apagar as analogias. O que lá vai lá foi, é como se diz. E pede se uma esponja sobre o passado. Amortalha-se o tirano em silêncio piedoso e entrega-se ao crepúsculo a sua biografia ainda viva, ainda legível e contemporânea das vozes testemunhais, para que em breve ela se torne enigmática e mitificada. ${ }^{357}$

Os narradores cardosianos quase sempre são jornalistas, contadores de estórias, escritores ou detetives que atuam através da palavra para ler e interpretar o espaço em que vivem. Todos apresentam afinidade com a escrita e aparecem na narrativa representados de alguma maneira, como José Cardoso Pires ${ }^{358}$. Os personagens buscam, com suas escritas ou com seus atos, entender situações, algumas vezes extremas, para em seguida questionar os valores que estão no

${ }^{356}$ PIRES, José Cardoso. E agora, José?, cit., p. 181.

${ }^{357}$ PIRES, José Cardoso. Post-scriptum. In: O burro em pé, cit., p. 118-119.

358 Segundo Cardoso Pires, “dificilmente algum artista ou algum escritor conseguirá iludir ou apagar o reflexo de si próprio na ordenação das coisas que descreve" (PIRES, José Cardoso. Dispersos 1, cit., p. 111). 
cotidiano do contexto político-social repressor, com o objetivo de revelar, desvendar fatos que conduzam o leitor a uma reflexão sobre suas descobertas.

Durante a ditadura salazarista, qualquer abordagem que remetesse aos “intelectuais" significava frequentemente pensar em contestação. Salazar queixava-se de que "teve sempre grande dificuldade em encontrar colaboradores, e que os intelectuais the fugiram sempre" ${ }^{, 359}$. Eduardo Lourenço assim se pronuncia sobre essa questão: "O intelectual mais típico entre nós tem sido o da oposição.” ${ }^{360}$ De fato, alguns escritores nunca deixaram de combater a repressão salazarista, ou seja, criaram instrumentos para se contrapor às ficções oficiais. Por meio da Literatura, foram capazes de romper a rede de poder, desarticulando e revelando os mecanismos camuflados com os quais se "saltava sobre a palavra e devorava-a” ${ }^{\text {361 }}$, como diz José Cardoso Pires.

Jacinto Prado Coelho ${ }^{362}$ afirma que a censura aparece como tema literário constante no histórico do panorama social e político de Portugal, pois a "censura como instituição"363 tem estado presente, ao longo da história, em toda a vida cultural portuguesa.

Em geral, a censura tem levado o escritor-intelectual, em virtude de seu caráter questionador e interventor, a atuar na clandestinidade e a criar seu contradiscurso "no fio da navalha" por meio de uma linguagem metafórica. Esse método ou processo de criação pode ser compreendido de duas maneiras, segundo Graça Almeida Rodrigues:

Se, por um lado, este subterfúgio desenvolveu a imaginação do autor, por outro, criou esquemas mentais de medo e de insegurança que não deixavam de pairar na mente dos escritores e, particularmente, dos jornalistas que, de fato, escreviam para o censor. ${ }^{364}$

No entanto, essas condições não impediram que José Cardoso Pires publicasse Dinossauro Excelentíssimo em 1972, quando a censura, sob as ordens

\footnotetext{
${ }^{359}$ RAMOS, Rui. Os intelectuais e o Estado Novo. Disponível em: <http://www.ciberkiosk.pt/ arquivo/ciberkiosk8/ensaios/intelectuais.html>. Acesso em:

${ }^{360}$ LOURENÇO, Eduardo. Cultura e política na época marcelista apud RAMOS, Rui. Os intelectuais e o Estado Novo. Lisboa: Cosmos, 1996.

${ }^{361}$ PIRES, José Cardoso. Dinossauro Excelentíssimo, cit., p. 94-95.

${ }^{362}$ COELHO, Jacinto Prado. Originalidade da literatura portuguesa. 2. ed. Lisboa: Instituto de Cultura e Língua Portuguesa, 1983.

363 Ibid., p. 7.

${ }^{364}$ Ibid., p. 92.
} 
dos órgãos competentes, retirava de circulação qualquer discurso que pudesse comprometer o sistema político vigente. Através da fábula, o autor conseguiu denunciar habilmente "certos mecanismos de funcionamento do político, certas relações de poder"365 e dissertar sobre o poder da palavra, sobre o jogo de significação que constitui o texto literário. Neste, o jogo com as palavras é um procedimento capaz de gerar sempre um duplo sentido dos fatos. Por esse motivo, o texto literário tem sempre uma função subversiva, pois "Denuncia o poder, mostra não apenas o que existe, mas também fala do que nunca existiu, apontando para a possibilidade de sua existência." 366

A fábula Dinossauro Excelentíssimo apresenta essa função de denunciar e, por isso, seria suscetível de censura. Mas um debate político provocou uma reviravolta em sua trajetória junto à política de censura, que naquela época estava sob o comando de Marcelo Caetano ${ }^{367}$, após o afastamento de Salazar. Segundo José Cardoso Pires,

Quando o texto foi lançado à circulação das letras nacionais, devidamente assinado e nos caracteres correntes, os animais da Corte desataram a assoprar nos covis de ouro. Na Assembléia Nacional o polvo almirante e o escorpião salazarento subiram à tribuna para excomungar e perseguir (devo-lhes a eles uma parte do êxito desse livro) e imediatamente apareceram os censores voluntários a rastejarem o ventre felpudo. No zénite da Comarca Lusitana hasteou-se a máscara do Excelentíssimo com uma provocação policial ao país silenciado. ${ }^{368}$

Esse episódio (Anexo - Figura 10) revela-nos o jogo político que envolve a atuação do "lápis azul", a caçar e cassar os textos que questionavam o regime político da época. Para Cardoso Pires, publicar nesse contexto teve "a grandeza de uma resistência que se tornou heróica e dia a dia renovada com ardis e exemplos de insubmissão"369. Nesse sentido, o texto literário pode ser entendido "como um pronunciamento, um ato de intervenção e interpelação face à realidade social e

\footnotetext{
365 PIGLIA, Ricardo. Ler errado é muito produtivo, cit., p. 17.

${ }^{366}$ FIORIN, José Luiz. Língua, discurso e política. Alea. V. 11, n. 1, p. 160, jan./jun. 2009.

367 Segundo José Cardoso Pires: “O inverno liberal de Marcello Caetano prometeu-se primavera, anunciando à primeira hora certos caminhos de abertura que corrigissem o colonialismo mental do velho ditador [Salazar]. Uma Lei de Imprensa, pelo menos, em que se pusesse fim à Censura e se pacificasse, como se diz, a Família Portuguesa. Mas em Março de 69 o herdeiro de Salazar adiava o projecto; três anos depois, Maio de 71, voltava à mesma" (PIRES, José Cardoso. Técnica do golpe de censura, cit., p. 194).

${ }^{368}$ PIRES, José Cardoso. Post-scriptum. In: O burro em pé, cit., p. 117-118.

${ }^{369}$ PIRES, José Cardoso. Técnica do golpe de censura, cit., p. 163.
} 
política $^{, 370}$, isto é, ele se estabelece como um projeto estético e político. No mesmo sentido, podemos concluir que, se o poder do discurso pedagógico está nas mãos do Estado - segundo Piglia, "La idea, entonces, de que el Estado también construye ficciones: el Estado narra" ${ }^{371}$-, então o discurso opositor está nas mãos daquele que, conforme Sartre, "se mete no que não é de sua conta",372. Nesse sentido, é preciso abordar a questão com a consciência de que a "censura", em Portugal, há muito tempo vinha ocupando espaço no contexto cultural, gerando tensões entre a repressão (estado de censura) e a insubmissão dos escritoresintelectuais. É sobre essa situação que temos de nos interrogar acerca da validade de modelos de interpretação concorrentes.

Portanto, Cardoso Pires não deixou de questionar, ainda que a censura estabelecesse "a conveniente confusão de valores, necessária a humilhar os

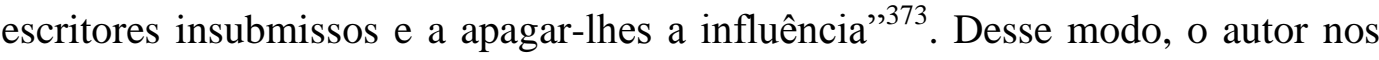
possibilita a leitura da ditadura salazarista pelo viés de outra lente, cuja perspectiva se concentra principalmente sobre o cotidiano esquecido ou encoberto pela história oficial.

De acordo com Cardoso Pires, a conduta de um escritor deve ser a de um "animal incomodo"374 porque está sempre "a duvidar e a interrogar a si e o mundo" 375 . Nesse sentido, concluímos que a estratégia dos escritos cardosianos está centrada na ação de interrogar para incomodar. Esse procedimento leva o autor a ler e a criar versões paralelas que se contrapõem às versões espalhadas pelo estado salazarista. Izabel Margato, a propósito do mesmo assunto, afirma: "um escritor pode revelar-se também como um pronunciamento, um ato de intervenção e interpelação face à realidade social e política."376

\footnotetext{
${ }^{370}$ MARGATO, Izabel. O intelectual em tempos difíceis, cit., p. 154.

${ }^{371}$ PIGLIA, Ricardo. Tres propuestas para el próximo milenio (y cinco dificultades). Conferência. Havana: Casa de las Américas, 2000. Boletin CCyDEL. Mexico: Centro Coordinador y Difusor de Estudios Latinoamericanos (CCyDEL) - atual Centro de Pesquisas sobre a América Latina e o Caribe (CIALC) - Universidade Nacional Autônoma do México, año XLI, n. 222, Enero / Marzo 2001. Disponível em: <http://www.ccydel.unam.mx/BOLETIN/boletin_6_7/revistas/ca sa222.htm>. Acesso em: 8 maio 2013.

372 SARTRE, Jean-Paul. Em defesa dos intelectuais, 1994, p. 30.

${ }^{373}$ PIRES, José Cardoso. Técnica do golpe de censura, cit., p. 188.

${ }^{374}$ PIRES, José Cardoso. Dispersos 1, cit., p. 91.

375 Loc. cit.

${ }^{376}$ MARGATO, Izabel. O intelectual em tempo difíceis, cit., p. 154.
} 
Portanto, podemos dizer que o olhar do intelectual possibilita que ele entreveja as tênues realidades entrelaçadas às vozes sociais, que arquitetam "efeitos de realidades", pois talvez seja possível "imaginar primero una literatura y luego inferir la realidad que le corresponde, la realidad que esa literatura postula e imagina",377. Parece que é justamente este "mirar las cosas desde un lugar levemente marginal" ${ }^{378}$ que provoca constantes debates sobre o que é ser intelectual.

Através desse método de intervenção, Cardoso Pires cria leituras e perspectivas de histórias diferentes daquelas propagadas pela fala oficial. $\mathrm{O}$ autor, quando lê a partir do que está subentendido nos relatos estatais, torna visível o invisível através da fixação de "imagens nítidas que já não vemos, mas que continuam insistindo como fantasmas e que vivem entre nós"379. Isso nos leva a compreender que o desafio da escrita se encontra na argúcia de saber ler e em seguir pistas possíveis. Assim, Cardoso Pires lê, investiga e interroga valores, ações e comportamentos da sociedade portuguesa à época do Estado Novo. Consequentemente, se, de um lado, a censura pode claramente proibir dizer, de outro, José Cardoso Pires pode rebelar-se e revelar, através do discurso literário transgressor, o modo como a censura "impede que certos discursos sejam proferidos ${ }^{380}$.

Segundo Piglia, cabe ao intelectual "actuar como un detective, descubrir el secreto que el Estado manipula, revelar esa verdad que está escamoteada"381, pois, para ele, o intelectual é aquele que diz "não". Na fábula, como visto, observamos um embate político, porque, enquanto o discurso político ditatorial está nas mãos do protagonista, o contraponto, o discurso político do insubmisso, é responsabilidade de alguns mexilhões, os contestadores. Diz Cardoso Pires:

No puzzle de subjetivismos e de desconfianças em que jogavam as linhas mestras da Censura, o coeficiente individual era uma fator de importância de que ambas as partes, perseguido e perseguidor, procuravam tirar partido. Como nas situações clássicas de tensão entre dois elementos polarmente opostos mas obrigados a

\footnotetext{
${ }^{377}$ PIGLIA, Ricardo. Tres propuestas para el proximo milenio (y cinco dificultades), cit.

${ }^{378}$ Ibid.

${ }^{379}$ PIGLIA, Ricardo. O último leitor. Trad. Heloisa Jahn. São Paulo: Companhia das Letras, 2006, p. 13.

${ }^{380}$ FIORIN, José Luiz. Língua, discurso e política, cit., p. 154.

${ }^{381}$ PIGLIA, Ricardo. Tres propuestas para el proximo milenio (y cinco dificultades), cit.
} 
enfrentar-se numa rotina de convívio, as relações censurado-censor corriam o risco de 'personalizar-se', de iludirem, digamos, a sua fronteira ideológica. ${ }^{382}$

Embora Cardoso Pires não nomeie o escritor como "intelectual", podemos inferir que essa postura de "duvidar" e de se "interrogar" sobre as verdades do mundo seja inerente às ações de um intelectual. Nesse sentido, o escritor pode ser considerado um intelectual porque se pronuncia a partir do lugar em que exerce o seu saber ${ }^{383}$, ou seja, da escrita, "lugar" a partir do qual lança seu olhar, em meio às diversas versões que se cruzam no contexto social do "tempo português" 384 , que, transfigurado, se torna

[...] uma realidade abstractizada, inconfundível. Tempo onde dificilmente ocorre o acontecimento vertical, incontroverso. Tempo entre a notícia e o boato; das muitas justificações; do que circula e não se vê; e que obriga o romancista a sucessivas abordagens dos heróis, focando-os em vários ângulos, deslocando-os, procurando sincronismos, suspensões. ${ }^{385}$

Ao analisarmos o papel do intelectual na sociedade contemporânea, encontramos algumas concepções sobre sua função. Mas a que se assemelha àquela descrita por Cardoso Pires, a de ser um animal incômodo, é a defendida por Edward Said, para quem o papel do intelectual é, "antes de mais nada, o de apresentar leituras alternativas e perspectivas da história outras que aquelas oferecidas pelos representantes da memória oficial" ${ }^{\text {386; }}$; no entanto, não podemos abandonar a concepção de Bobbio $^{387}$, para quem o intelectual é aquele que pensa sobre as coisas, que trabalha com símbolos e ideias. Talvez essas concepções se complementem no que se refere à atuação de Cardoso Pires enquanto escritor, pois, além de apresentar leituras alternativas, ele o faz através de estratégias complexas de concretização de ideias sobre os problemas vivenciados pela sociedade

\footnotetext{
${ }^{382}$ PIRES, José Cardoso. Técnica do golpe de censura, cit., p. 188.

${ }^{383}$ Essa é a função que o intelectual representa nos escritos de Michael Foucault. Segundo o autor, "o papel do intelectual não é mais o de se colocar 'um pouco na frente ou um pouco de lado' para dizer a muda verdade de todos; é antes o de lutar contra as formas de poder exatamente onde ele é, ao mesmo tempo, o objeto e o instrumento: na ordem do saber, da 'verdade', da 'consciência', do discurso" (FOUCAULT, Michel. Microfisica do poder, cit., p. 71).

${ }^{384}$ PIRES, José Cardoso. Dispersos 1, cit., p. 107.

385 Loc. cit.

${ }^{386}$ SAID, Edward. O papel público de escritores e intelectuais. In: Trad. Luiz Bernardo Pericá. São Paulo: Boitempo, 2003, p. 39.

${ }^{387}$ BOBBIO, Norberto. Os intelectuais e o poder: dúvidas e opções dos homens de cultura na sociedade contemporânea. Trad. Marco Aurélio Nogueira. São Paulo: Ed. Universidade Estadual Paulista, 1997, p. 68.
} 
portuguesa. Portanto, entendemos que José Cardoso Pires atua, enquanto intelectual, como um leitor que constrói e questiona sentidos, como um decifrador de enigmas, como um interprete de fatos históricos, como um escritor incômodo.

Piglia explica que o ato de ler tem a função de construir sentidos, o que gera no intelectual a dúvida, a incerteza "quanto à interpretação, quanto às múltiplas possibilidades da leitura" ${ }^{388}$. Essa postura diante da incerteza da leitura promove, consequentemente, "uma tensão entre o ato de ler e a ação política" ${ }^{389}$. E, se para Cardoso Pires o ato de narrar é um jogo, a ação política é uma prática voltada para a interpretação, que, na narrativa cardosiana, passa pelo Jogo do Olho Vivo.

Utilizando-se desse jogo, o de reescrever a História na história ocultada, o contador de estórias segue as pegadas do Dinossauro para narrar a história da censura "num tempo em que os jornais não andavam nada claros" ${ }^{\text {"390 }}$ e também para mostrar como os fatos são recolhidos, selecionados e muitos deles embaçados "nos capítulos nevoentos da História" ${ }^{391}$. Assim, para Cardoso Pires, contar é interrogar vestígios, rastros, pegadas, para, em seguida, revelá-los sob os mais diversos ângulos.

Percebemos que as estratégias com as quais Cardoso Pires arquiteta seus textos apresentam-se como enigmas, como iscas provocadoras, que atuam de forma semelhante aos índices, constituindo-se como o que passamos a chamar poética da decifração. O narrador cumpre o papel de caçador, de farejador dos rastros encobertos pelos "lápis azuis", e age de modo semelhante ao do caçador descrito por Carlos Ginzburg, porque, para o teórico, o homem "Aprendeu a farejar, registrar, interpretar e classificar pistas infinitesimais ${ }^{\text {"392 }}$.

Partilhando a ideia de um narrador-leitor como decifrador de rastros, Piglia sintetiza essa imagem quando afirma que uma das maiores representações modernas da imagem do leitor "é a do detetive [...] do gênero policial"393, do leitor que decifra "coisas da História que tem destes passos sem rastros para despistar os curiosos" ${ }^{\text {"394. }}$. Desse modo, ao atuar como intelectual, Cardoso Pires é

\footnotetext{
${ }^{388}$ PIGLIA, Ricardo. O último leitor, cit., p. 98.

${ }^{389}$ Loc. cit.

${ }^{390}$ PIRES, José Cardoso. Técnica do golpe de censura, cit., p. 105.

391 Ibid., p. 130.

${ }^{392}$ GINZBURG, Carlos. Mitos, emblemas, sinais: morfologia e historia. Trad. Federico Carotti. São Paulo: Companhia das Letras, 1989, p. 151.

${ }^{393}$ PIGLIA, Ricardo. $O$ último leitor, cit., p. 74.

${ }^{394}$ PIRES, José Cardoso. Dinossauro Excelentíssimo, cit., p. 18.
} 
um escritor que vem revelar "os assuntos que são sistematicamente esquecidos ou varridos para debaixo do tapete" 395 .

A imagem desse puzzle ficcional só é possível porque, como diz Said, o intelectual exilado ${ }^{396}$ pode "ver as coisas, não apenas como elas são, mas como se tornaram no que são"397. Deste modo, o intelectual faz surgir, torna visíveis e ilumina ângulos até então obscurecidos pelos fios que teceram a memória do discurso historiográfico. Através da fábula, discurso fictício, tomamos conhecimento e percebemos outras perspectivas dos fatos. E o próprio autor, ao escrever um post-scriptum na primeira edição ${ }^{398}$ da coletânea de contos Burro em pé, retomava o objetivo de reeditar Dinossauro Excelentíssimo:

Neste exemplar que ignoro onde irá ancorar (continuo eu nessa nota de 1973) fica o post-scriptum. Ele é como um aviso lançado à corrente, ao destinatário do acaso, e é assim que o desejo: em forma de mensagem corsária e como tal redigido em apagamento e repleto de indignação.

Seis anos passados sobre esta minha anotação de circunstância muita coisa mudou no país que outrora foi comarca à margem e que hoje é pátria de homens, felizmente. Mas há desmemórias e mentira a lavrar por entre nós e forças interessadas em desdizer a terrível experiência do passado transformando-a numa calúnia ou em algo já obscuro e improvável. É por isso, e só por isso, que retomei o Dinossauro Excelentíssimo e o registro como uma descrição incómoda de qualquer coisa que oxalá se nos vá tornando cada vez mais fabular e delirante. ${ }^{399}$

\subsection{A censura ou câmara de torturar palavras}

No ensaio "Técnica do golpe de censura", editado em 1977, Cardoso Pires denuncia como a prática e os mecanismos da censura foram usados durante o regime salazarista, e esclarece como, perpetuado durante séculos por diversas gerações, o discurso do poder da censura ainda perdurava, pois eram "milhares de

${ }^{395}$ SAID, Edward. Representações do intelectual, cit., p. 28.

${ }^{396}$ Exilado no sentido que lhe atribui SAID, Edward W. Representações do intelectual, cit., p. 57-60.

${ }^{397}$ Ibid., p. 60. Segundo Said: "O exílio significa que iremos ser sempre marginais e que o que fazemos enquanto intelectuais tem de ser inventado, na medida em que não podemos seguir um caminho prescrito" (Ibid., p. 61).

398 Esta obra de José Cardoso Pires foi publicada em dezembro de 1979 por Moraes Editores, ilustrada por Júlio Pomar e capa de Sebastião Rodrigues. Mais tarde, em 1999, foi editada pelas Publicações Dom Quixote e em 2010 foi publicada por Leya. Fazem parte do livro os contos seguintes: Os reis - mandados; O conto dos chineses; Nós, aqui por entre o fumo; Dinossauro Excelentíssimo (versão revista pelo Autor após o 25 de Abril); e Celeste \& Làlinha: por cima de toda a folha; além do post-scriptum referido.

${ }^{399}$ PIRES, José Cardoso. Post-scriptum. In: O burro em pé, cit., p. 118-119. 
quilômetros de textos lançados às fogueiras e aos arquivos" ${ }^{400}$. Do mesmo modo, em Dinossauro Excelentíssimo o Imperador "limpa" quilômetros de palavras através de um invento que lhe é muito caro: "a câmara de torturar palavras" "401, cuja função é semelhante à do celebre "lápis azul" usado pelos censores ${ }^{402}$ portugueses - ou seja, livrar o Reino das palavras que incomodam o Imperador, palavras com o significado de "vozes" que o Estado quer, a todo custo, calar.

No Estado Novo português, o controle político e a censura da escrita trabalhavam juntos; de acordo com Cardoso Pires, a Dura Pax almejava estabelecer uma atmosfera de medo, criar um "pacto de convívio entre opressores e oprimidos, o sonho de qualquer totalitarismo é sempre esse" ${ }^{\text {"403 }}$. Por esse motivo, Salazar tencionava radicar a repressão como "um hábito social, uma prática familiar de dissuasão"404 - ainda que os homens do Estado Novo afirmassem que a censura era um "mal necessário".

Durante esse regime extremamente opressor, Salazar se dedicou a fazer da censura uma "sintaxe do pensamento coletivo, uma autêntica profilaxia do estado que não visava apenas a controlar mas a criar formas de mentalidade adaptada ao Poder" ${ }^{405}$. Cardoso Pires diz que um levantamento estilístico da língua portuguesa daquela época

[...] poderia detectar a influência da Censura nas sucessivas metamorfoses do discurso literário. Nos magazines, nos suplementos culturais, na rádio "institucionalizou-se" um estilo clandestino, ilustrado por metáforas que se popularizaram nos fins dos anos 40 e que conferiram à prosa (e à poesia) do pósguerra aquele halo romântico que a caracterizava. Aurora entrou no dicionário como sinônimo de Socialismo nascente, primavera como Revolução, papoula o mesmo que estandarte vermelho comunista; onde estava companheiro ler-se-ia camarada de luta e em vampiro bufo, informador. Como o calão, que é uma forma de defesa e de coesão das comunidades perseguidas, a linguagem escrita substituía

\footnotetext{
${ }^{400}$ PIRES, José Cardoso. Post-scriptum. In: O burro em pé, cit., p. 163.

${ }^{401}$ PIRES, José Cardoso. Dinossauro Excelentíssimo, cit., p. 56.

402 Segundo Cardoso Pires, "A todo o passo o censor zeloso sobrepunha o quid subjetivo ao conteúdo especifico do objeto censurável e para isso não hesitava: tinha à mão um arsenal de rubricas convenientemente elásticas para protegerem qualquer vício de julgamento e toda e qualquer deficiência de informação. 'Desprestígio das instituições', 'pornografia', 'desmoralização da família', 'abuso da liberdade (sic) de expressão' e outras alíneas como estas desfrutavam da amplitude dos enunciados bíblicos e era nelas que os burocratas da opinião oficial se instalavam para investir contra a afirmação menos intencional. A partir daqui, nada feito - todo o vocábulo passaria a ter a tradução livre do prontuário da Censura e toda a frase era susceptível de conter, na mais longínqua conotação, os ópios da clandestinidade" (PIRES, José Cardoso. Visita à oficina o texto e o pré-texto II, cit., p. 168-169).

${ }^{403}$ PIRES, José Cardoso. In: PORTELA, Arthur. Cardoso Pires por Cardoso Pires, cit., p. 38.

404 Loc. cit.

405 Ibid., p. 163.
} 
as imagens convencionais por outras que ia recolher ao prontuário subterrâneo da juventude politizada e à poesia de combate. ${ }^{406}$

Em Dinossauro Excelentíssimo, Cardoso Pires relata ironicamente um episódio em que se pode perceber essa mesma questão, pois, no reino dos Mexilhões, o Imperador, como censor, manipula o significado da palavra para criar outra realidade. Isto é, se, num primeiro momento, os mendigos são personagens desassistidos pelo governo, ao se tornarem inadaptados, são considerados pessoas que estão fora do lugar; logo, deixam de ser preocupação para o governo. Nesse sentido, o eufemismo para o vocábulo "mendigo" confere a estes a responsabilidade pela não-adaptação às condições de vida em sociedade. Há um relato ${ }^{407}$ de Cardoso Pires sobre essa questão que nos parece mais um texto com ideias semelhantes.

Por exemplo, uma vez apareceu-lhe o Patriarca do Alto Comércio e, senhores, o que ali ia, o que ali ia. $\mathrm{O}$ homem mostrava-se desnorteado:

"NÃO POSSO MAIS, EXCELÊNCIA. OS EXCELENTÍSSIMOS MENDIGOS TIRAM-ME O SONO COM PEDIDOS."

O Imperador encolheu os ombros. Trocou simplesmente a palavra: Mendigos? Quais mendigos? - E deu o problema por resolvido: inadaptados é o que o cavalheiro do alto comércio queria dizer. Inadaptados.

"E, POR AMOR A DEUS, INADAPTADOS SEMPRE EXISTIRAM E CONTINUARÃO A EXISTIR ATÉ NOS REINOS MAIS PRÓSPEROS. DURMA EM PAZ." 408

Na fábula em estudo, o narrador conta à sua filha Ritinha a história de um Imperador que manipulava e torturava a palavra no Reino dos Mexilhões. O personagem limpava as palavras na tentativa de que seus súditos se comunicassem através de um discurso homogêneo, de modo que todos no Reino, principalmente os Mexilhões, não tivessem como questionar as ordens impostas por esse grande

\footnotetext{
${ }^{406}$ PIRES, José Cardoso. E agora, José?, cit., p. 174.

${ }^{407}$ Cardoso Pires relata um episódio que envolve a censura e seus escritos: "Uma vez, cheguei a escrever três artigos sobre o mesmo assunto - sobre o natal - e todos foram proibidos, porque neles eu aludia aos pobres que, nessa noite, tinham frio. Chega a parecer inverossímil, pelo que há de ingénuo nisto, que as esferas oficiais houvessem deliberado fazer acreditar o país e o estrangeiro que em Portugal ninguém tinha frio, nem fome, nem miséria, que havia, portanto, um Portugal que nós não víamos em parte alguma e que era diferente daquele país que nós víamos todos os dias e em toda a parte" (AZEVEDO, Cândido de. A censura de Salazar e Marcelo Caetano. Lisboa: Caminho, 1999, p. 27).

${ }^{408}$ PIRES, José Cardoso. Dinossauro Excelentíssimo, cit., p. 52.
} 
ditador, que almejava perniciosamente reduzir os Mexilhões ao silêncio (Anexo Figura 11).

Na fábula, o narrador enfatiza, principalmente, a obsessão do Imperador pela caça às palavras:

Dito e feito. Mãos ao trabalho, e ei-lo a limpar decretos e alíneas, jornais, compêndios - o que calhava. Palavras correntes, mais vivas ou menos próprias, fogueira com elas porque pingavam de certeza veneno nas entrelinhas. Outras, quase esquecidas nas rugas dos pergaminhos, essas é que sim: convinha ir buscálas, tirar o pó e lançá-las em circulação, quanto mais depressa melhor. E aqui para nós, havia muitas, muitíssimas. Palavras de puro sangue latim e grego, que além dos atestados de nobreza, tinham cheiro santificado, essência de rendas velhas. ${ }^{409}$

O aspecto citado demonstra a característica do poder da censura e a obsessão de apagar as palavras que poderiam fugir à ORDEM: "Quanto tempo gastou o Imperador a estudar a maneira de se ver livre das palavras que incomodavam? [...]. A fala dos mexilhões era passada a crivo havia orelha de morcego a caçá-la nas dobras da sombra, imagine-se." ${ }^{410}$ Obstinado por esse "jogo de ordem”, o Imperador criou uma câmara de torturar palavras, onde as submetia à purificação, para eliminar delas o pernicioso veneno das ambiguidades. Assim, tecia habilmente um novo imaginário, opaco e sem contradições, ou que pudesse provocar dúvidas quanto ao sentindo sobre o que se queria dizer. No entanto, com astúcia se poderia desarticular aquela "máquina de tortura", pois, como o narrador explica, para tanto bastava que uma palavra ganhasse vida; ou seja, a partir da obtenção de um discurso purificado, a palavra se subverteria, criando, através de um novo jogo de ordem, um novo significado. Importa referir que a palavra nesse contexto pode estar metonimicamente representando o próprio discurso que o ImperadorDinossauro deseja propagar.

Embora o Dinossauro tentasse limpar as palavras, elas transitavam transgressoras por todo o Reino como propagadoras das ideias insurretas. Logo, ao narrar a estória do dinossauro, Cardoso Pires concomitantemente denuncia e testemunha o regime totalitário do Estado Novo português.

Para exercer seu poder, o Dinossauro Excelentíssimo teceu sua teia ideológica com a intenção de moldar os espíritos e legitimar o direito de mandar,

\footnotetext{
${ }^{409}$ PIRES, José Cardoso. Dinossauro Excelentíssimo, cit., p. 51.

${ }^{410} \mathrm{Ibid}$., p. 55.
} 
cassando e anulando o direito de resistir, "com isso justificando e tornando aceitável, como coisa natural, o dever de obedecer. Por isso mesmo, e em certo sentido, os discursos ideológicos, por sobre o seu conteúdo, valem pela função disciplinadora que veiculam". 411

A censura durante a ditadura salazarista impôs ao escritor português "uma permanente e insidiosa auto-censura, apenas ultrapassada pelo engenho do próprio escrever entre-linhas" ${ }^{\prime 412}$. Esse recurso de poder censurar tornou-se extremamente sofisticado na fábula, porque o Imperador criou um sistema complexo e sofisticado para "desempestar o Império e as consciências queimando o termo grosseiro e a frase manhosa" ${ }^{413}$. E para atingir seu objetivo, o Imperador "instalou labirintos, olhos eletrônicos, cabelos de platina, deu instruções secretas a computadores de inconcebível crueldade - e ao ver a máquina a funcionar, esfregou as mãos: agora sim, a música ia ser outra." ${ }^{414}$

Estabelecida a "censura", os mexilhões Dê-Erres tentaram silenciar toda expressão individual: o vestir, o rir, o falar e o alegrar, ou seja, todas as manifestações humanas que são expressas através de linguagens. Portanto, destroem a fala e constroem o silêncio e ao mesmo tempo obrigam "os mexilhões a vestir de escuro porque a vida não estava para graças e decretaram que de futuro o riso seria máscara do desdém, o falar a capa dos ignorantes e a alegria o fumo da inconsciência"415.

Dando sequência ao seu plano de limpar as individualidades do reino, o Imperador planejou criar uma "língua limpa e severa, em que todos se entendessem ${ }^{416}$, e, ao tentar homogeneizar a fala, conseguiu eliminar as rasuras e as contradições que a língua individual permite. Mas, ainda que ele criasse uma língua "sem rasuras", isso não seria suficiente para impedir que uma palavra, vez ou outra, resolvesse se rebelar. Pensando nisso, o Imperador-Dinossauro conseguiu imaginar um mecanismo mais eficiente para "espionar" a fala dos mexilhões, e instalou no Reino uma "máquina de torturar palavras", com a função

\footnotetext{
${ }^{411}$ ROSAS, Fernando. História de Portugal, cit., p. 259.

${ }^{412}$ RODRIGUES, Graça Almeida. Breve história da censura literária em Portugal. Lisboa: Bertrand, 1980, p. 76. Biblioteca Breve, v. 54.

${ }^{413}$ PIRES, José Cardoso. Dinossauro Excelentíssimo, cit., p. 72.

${ }^{414}$ Ibid., p. 55.

415 Ibid., p. 45.

${ }^{416}$ Ibid., p. 51.
} 
de purificar as palavras a fim de não comprometer sua ordem, visto que só com esse processo de ele atingiria o objetivo de se livrar dos venenos que "pingavam de certeza [...] nas entrelinhas" ${ }^{\wedge 17}$ da fala dos mexilhões.

Essa sofisticada técnica de controle, sob a forma de "olhos electrónicos", foi instalada numa torre, e a imagem descrita pelo narrador nos permite associá-la estrutura panoptikon ${ }^{418}$, isto é, “que o olho veja, sem ser visto - aí está o maior ardil do Panóptico"419. Assim, o Imperador dedicava-se cada vez mais a esse processo de limpeza, e, embora levasse uma vida monástica em sua torre, seu gabinete mais lembrava o inferno, com os "computadores, zzz-zumbidos, cliques, a fita de registro desfiando condenações" ${ }^{2420}$.

A máquina funcionava a todo vapor: "Matraqueavam códigos, despejavam registros, à medida que a agonia de sons ia crescendo arrastada pelos zumbidos da corrente, pzz... pzzzz..." 421 . Finalmente, caiu "uma palavra na teia, uma das tais" 422 , a envenenada. Era por meio dessa "câmara de torturar palavras" que o Imperador conseguia vigiar o Reino e impor o silêncio com seu "código-espia"423 e sua "máquina infernal",424.

A partir desse exercício de poder manipular, observamos as duas faces do ditador: a primeira está relacionada à propagação de um discurso escamoteado, velado, do Reino, manipulado segundo a vontade do Imperador; a segunda é relativa ao ato de censurar, quando elimina na máquina o que ele chama de palavras venenosas, isto é as camadas de significado que as palavras vão acumulando ao longo dos anos.

\footnotetext{
${ }^{417}$ PIRES, José Cardoso. Dinossauro Excelentíssimo, cit., p. 51.

${ }^{418}$ Com esse projeto, Jeremy Bentham pretendeu criar "um instrumento inigualável de poder para os governos, permitindo o controle de uma massa de homens de maneira que suas ações, suas relações, qualquer circunstâncias de suas vidas, mesmo as impressões que o meio lhes determina pudessem ser previstas em todos os seus efeitos. Este instrumento de controle poderia ser usado com diversos objetivos pelos governos. [...] o uso desse instrumento de poder formidável seria feito com grande economia, sem o dispêndio das custosas vigilâncias feitas por um grande número de guardas. À eficácia da forma de controle sugerida somava-se o seu baixo custo: apenas um homem bastaria para acioná-lo" (MURICY, Kátia. Os olhos do poder. In: NOVAES, Adauto et al. O olhar. São Paulo: Companhia das Letras, 1988, p. 483).

${ }^{419}$ MILLER, Jacques-Alain. A máquina panóptica de Jeremy Bentham. Trad. M. D. Magno. In: BENTHAM, Jeremy. O Panóptico. Org. Tomaz Tadeu da Silva. Belo Horizonte: Autêntica, 2000, p. 78.

${ }^{420}$ PIRES, José Cardoso. Dinossauro Excelentíssimo, cit., p. 97.

${ }^{421}$ Ibid., p. 53-54.

${ }^{422}$ Loc. cit.

${ }^{423}$ Ibid., p. 58

${ }^{424}$ Loc. cit.
} 
O processo de depuração linguística é descrito pelo narrador: Depois de passar por várias camadas de tratamento ou de "tortura", a palavra finalmente chega ao "complexo de recuperação (lavagem e filtros), que, depois de purificar a palavra, a recompunha e transmitia aos ficheiros" ${ }^{225}$.

Mas o Imperador receava que os "mexilhões-anarquistas", que manipulavam o discurso tanto quanto ele, desarticulassem o mecanismo de censura que ele tão habilmente construiu. Seu temor residia principalmente em deixar passar alguns elementos perniciosos que poderiam colocar tudo a perder; anos de trabalho duro poderiam ser destruídos por causa de uma vírgula, um ponto de exclamação, sinais inocentes, mas que, em determinado contexto, ganham vida. Então o Imperador começou a falar consigo mesmo, associando aqueles elementos tão inofensivos ao risco iminente de um ponto a solto. Desse modo, o

[...] Imperador tomou as suas disposições [...]; reticências eram desculpas de tímidos e de inimigos disfarçados [...]. Nas pequenas coisas é que se via onde estava a Ordem, concluiu ele; e em pensamento destacou a palavra entre duas exclamações, firmes e reluzentes como uma guarda de honra de baionetas:

¡ORDEM! $!^{426}$

Ao tentar "moldar" o Reino, o Imperador agia como "um visionário utópico.

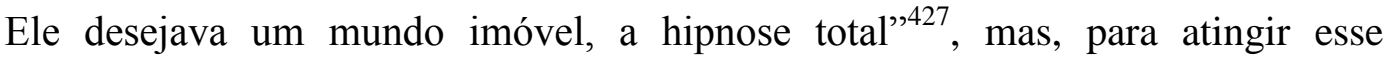
objetivo, precisava aguçar os punhais, a fim de organizar, adequar e controlar de perto as transformações que desejava promover. A censura seria o seu mecanismo repressor, pois era com esse procedimento que ele controlava as palavras soltas, com o objetivo de "assegurar regularidade e a estabilidade, em que as probabilidades possam ser controladas, desde que sigam uma hierarquia rigorosa; mundo onde as coisas não ocorrem por acaso" ${ }^{\text {428 }}$. Essa é concepção de mundo idealizada pelos ditadores, pois assim eles conseguem controlar a maior parte dos discursos que circulam na sociedade.

\footnotetext{
${ }^{425}$ PIRES, José Cardoso. Dinossauro Excelentíssimo, cit., p. 58.

${ }^{426}$ Ibid., p. 95-96.

427 ENZENSBERGER, Hans Magnus. Cismas portugueses. In: A outra Europa: impressões de sete países europeus, com um epílogo do ano de 2006. São Paulo: Companhia das Letras, 1988, p. 142.

${ }^{428}$ CUNHA, Helenice. A rede de palavras e a máscara de Imperador em Dinossauro Excelentíssimo, cit., p. 107.
} 
Importa retomar a questão da imagem alegórica: assim como temos a alegoria do poder e do ditador, analisada no início do capítulo, também entendemos que esse processo, descrito em seus detalhes, compõe uma imagem alegórica da tortura, pois a palavra estaria aqui representando metonimicamente a fala dos insubmissos, a limpeza seria como que um apagamento, semelhante ao método dos lápis azuis sobre os escritos que fugiam às regras.

O Imperador cria uma máquina de torturar palavras através do processo de decantação química, deslocando assim um saber anterior para o adaptar a uma realidade fictícia de depuração de palavras, que pensamos ser uma imagem alegórica. Como já analisamos, o Imperador controlava o significado das palavras, e esse controle lembra um processo "químico" de limpeza em pequenos compartimentos da máquina, que constituíam o Sistema de Seleções Progressivas, onde os significados venenosos eram retirados, procurando manter um significado ou sinônimo da palavra:

[...] eram combinadas com outros vocábulos que actuavam como catalisadores ou 'reagentes significantes'. Por esta operação obtinham-se os sinônimos e as intenções mais ocultas de cada palavra. [...] Devidamente desdobradas nas suas origens e significados, as palavras eram transportadas [...] e simultaneamente enviadas para o Complexo de recuperação (lavagem e filtros) que, depois de purificar a palavra, a recompunha e transmitia aos Ficheiros automáticos. ${ }^{429}$

Seguindo esse raciocínio, observamos que o Imperador-Dinossauro utiliza essa estratégia para ordenar as ideias, pois, quanto mais encaixadas e limpas, menos perigo elas oferecem ao censor. Nessa obsessão, ele sai à caça de todos os elementos que poderiam desordenar seu objetivo; por isso,

[...] lançou-se atrás do til, essa borboleta, e do trema em lantejoulas; distribuiu hífens, colocou-os com o cuidado com que se abrem cancelas no terreno selvagem das orações confusas. Ao sinal de parágrafo, minúsculo hipocampo entre folhas amortalhado, pô-lo a embelezar com abundância os decretos-leis da sua predileção; e à gota de mel, que era o ponto de exclamação, retirou-a aqui e ali para não tornar gulosa a frase. Isto, entre outros exemplos. ${ }^{430}$

Notamos que esse farejador de elementos linguísticos domina seu saber, visto que sabe exatamente o que buscar para evitar a ambiguidade, a dúvida, as "entrelinhas": a acentuação, as possibilidades de significados, a organização

\footnotetext{
${ }^{429}$ PIRES, José Cardoso. Dinossauro Excelentíssimo, cit., p. 57 (grifo nosso).

${ }^{430}$ Ibid., p. 97.
} 
sintática e, por fim, a pontuação, que pode mudar completamente o sentido de uma frase. Enfim, ele precisa estar preparado para perceber a manha da frase, as intenções nelas impressas de forma sutil, porque ele mesmo já "Tinha visto muito bacharel tropeçar na vírgula e estatelar-se a meio período; ou passar sem dar por ela e perder o fôlego antes do ponto final, o que não era menos desastroso",431.

Mesmo com todo o empenho para deixar em ordem a "fala do reino", o Imperador perdeu o controle, como veremos. O episódio revela que, ao final, o esforço do Imperador foi quebrado justamente pela palavra ORDEM, à qual o Imperador dedicou tanto tempo. E ao perder o controle, ele se desesperou, mas já não conseguiu controlar a palavra, que acabou saindo com outro significado: MEDO.

Certa manhã, estava ele muito sossegadinho a ver se ouvia, caiu um substantivo na rede: Pim!

De braço no ar, investiu contra a palavra, pronto a destroçá-la. Viu-a passar no circuito, singrando, explodindo, renascendo, enquanto a fita de registro anotava:

ORMED... OREDM... DEROM... MORED...

Mored? O Douktor Dinosaurus intrigou-se: seria algum código inimigo?

MORED... MORED...

Insistia o registro, crescendo pelo sobrado fora. E depois:

MORED... ORMED...

ORMED...

DEMO... RRRRR... DEMO...

\section{RRRRRRRRRRRRRRRR}

sinal, ponto, seta - MORDE ${ }^{432}$

O Imperador é traído por um substantivo (classe gramatical que designa as concepções dos seres); assim, a palavra “ordem" destrói a ordem e impõe medo ao Imperador - grande ironia, uma vez que ele fora escolhido em razão de sua qualidade "de camponês de gramática asseada" ${ }^{, 433}$. Nesse episódio, a palavra ganha qualidades animalescas: é uma cobra, símbolo ligado à traição, com toda a sua capacidade venenosa:

Aqui o enorme Dinossauro enfurece-se. Quis estrangular a cobra que não parava de crescer mas ela parecia assanhada, contorcendo-se nas cinco letras venosas que

\footnotetext{
${ }^{431}$ PIRES, José Cardoso. Dinossauro Excelentíssimo, cit., p. 96.

${ }^{432}$ Ibid., p. 112.

${ }^{433}$ Ibid., p. 96.
} 
eram a baba, a peçonha da palavra Ordem. Alongava-se aos uivos do sinal de alarme, subia pelo Imperador acima, enrolava-se nos punhos.

$[\ldots]$

MEDO... MEDO...

silvava ela, e avançava, destemida.

MEDO... RRR...

MEDOR... OREDM...

ODREM... ODREM...

RRRRRRRRRRRRRRRR

sinal, ponto, seta - ORDEM

Ordem?, urrou o Imperador, trespassado. Ordem... Medo... assoprava a cobra continuando a deslizar da toca dos computadores e amontoando-se aos molhos pelo chão. ${ }^{434}$

O esquema apresentado a seguir, elaborado por $\mathrm{Cunha}^{435}$, detalha o percurso de uma palavra que fugiu ao controle do Imperador e sofreu "depuração" para ganhar novo significado.

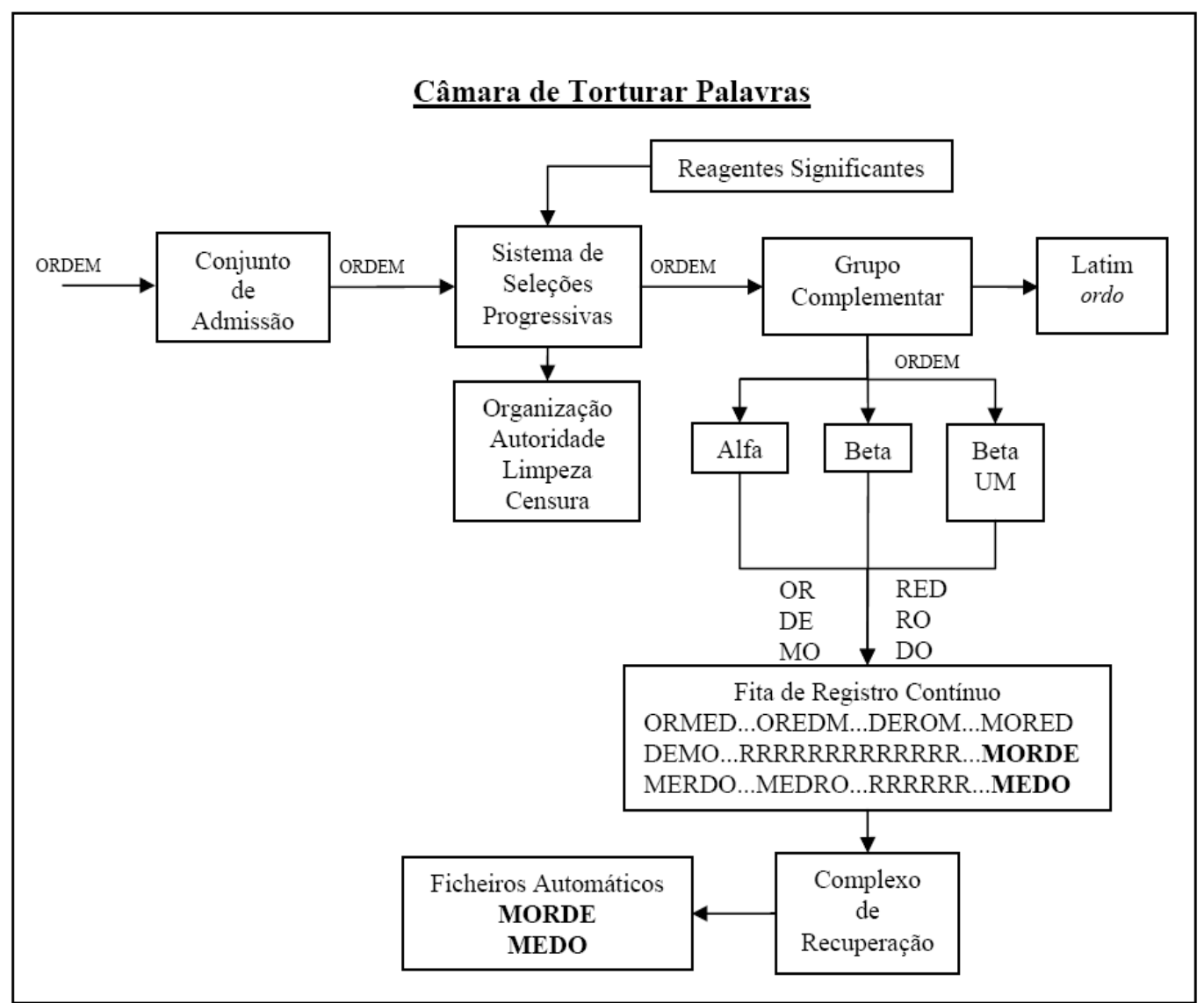

${ }^{434}$ PIRES, José Cardoso. Dinossauro Excelentíssimo, cit., p. 113-114.

435 CUNHA, Helenice. A rede de palavras e a máscara de Imperador em Dinossauro Excelentíssimo, cit. 
O esquema que explicita o mecanismo de censura parece concretizar ao mesmo tempo as ideias de tortura e de censura, visto que, nesse episódio, a palavra é personificada, ou melhor, é animalizada, sai do estágio de objeto inanimado, censurado, calado, e de repente começa a se exprimir e rompe a câmara de torturar palavras. Da mesma forma, a voz do narrador e a voz do autor também rompem o silêncio e a censura e se pronuncia, para que ninguém se esqueça de que um dia houve uma máquina de torturar palavras.

Enfim, para saber utilizar seu poder, o Imperador tramou com "saber e autoridade" um modo de usar a palavra como arma de silenciar, com o objetivo que fazer circular um saber que moldasse os espíritos e legitimasse o direito de mandar, anulando o direito de resistir, "com isso justificando e tornando aceitável, como coisa natural, o dever de obedecer. Por isso mesmo, e em certo sentido, os discursos ideológicos, por sobre o seu conteúdo, valem pela função disciplinadora que veiculam.",436

Cardoso Pires, com os "sapatos apertados", descobriu nova dança, fez da fábula uma confabulação, um murmúrio de denúncia, a meia palavra para um novo leitor, obrigando-nos a ler com os olhos de dinossauro, para aprendermos nas entrelinhas aquilo que ele quis dizer "mas não pôde dizer à vontade"437. Mas ele mesmo relata:

E uma bela madrugada as feras da arrogância e do terror ao verem surgir os soldados da liberdade fugiram a sete pés por todas as costuras do Reino. Essas coisas tiveram lugar a vinte e cinco de Abril do ano de 74, conforme é memória universal.

Naquela urgência de salvar e esquecer, os galos de briga perderam logo ali o esporão e a crista floriu-lhes em cravo de abril altivo; às víboras deu-lhes o sono brusco, hibernaram antes do tempo, e à hiena, foi fácil veio-lhe o choro da comoção. O chacal comprou coleira, vestiu-se de cão doméstico, e o crocodilo fezse de pedra; todo veludo e sombra, o morcego espalmou-se no campário, vizinho da cegonha máter e das santas columbas. Uma parte da bicharia pediu asilo ao jardim zoológico, outra embarcou na arca da salvação rumo aos brasis. ${ }^{438}$

\footnotetext{
${ }^{436}$ ROSAS, Fernando. História de Portugal, cit., p. 259.

${ }^{437}$ MORAND, Paul apud PIRES, José Cardoso. Visita à oficina o texto e o pré-texto II, cit., p. 165.

${ }^{438}$ PIRES, José Cardoso. Post-scriptum. In: O burro em pé, cit., p. 118.
} 


\section{CONCLUSÃO}

Sim, é o Estado Novo, e o povo

Ouviu, leu e assentiu.

Sim, isto é um Estado Novo

Pois é um estado de coisas

Que nunca antes se viu.

Fernando Pessoa ${ }^{439}$

Esta tese buscou aprofundar a análise de uma narrativa de José Cardoso Pires, não com a pretensão de possuí-la, ou de enquadrá-la em conceitos preestabelecidos, mas com o propósito de compreendê-la. Do texto literário, exaltamos a sua essência, por vezes deixando-o em aberto, outras, propiciando entradas e saídas, deslocando-o do seu contexto para completar o sentido de outro. Pretendemos esclarecer que esse movimento ocorre tanto na construção da obra quanto na leitura interpretativa da mesma, demonstrando que há uma atualização permanente do significar de um texto, como acontece com a narrativa aqui investigada, Dinossauro Excelentíssimo.

Após nossa análise, foi possível resgatar alguns conceitos que caracterizam o modus operandi da construção narrativa de Cardoso Pires, a exemplo do modo sagaz já referido, que é o de "andar sobre o gume da faca",440, uma de suas estratégias presente frequentemente em sua obra, como observamos na reflexão constante que o texto faz sobre sua própria composição. Além disso, percebemos que a ficção cardosiana tem um compromisso político, pois focaliza também o ponto de vista de anônimos: através das ações de seus personagens, ele é capaz de dissertar sobre temas que afligem o ser humano, ou levanta questões de caráter universal. Evidenciamos, ao longo da tese, que certas experiências podem ser vivenciadas também por outros personagens, fictícios ou não, envolvendo um contexto semelhante, como o da ditadura. Logo, há ramificações que dela possam

\footnotetext{
439 PAIS, Amélia Pinto. Fernando Pessoa, o menino de sua mãe. São Paulo: Companhia das Letras, 2009, p. 46.

${ }^{440}$ PIRES, José Cardoso. Visita à oficina: o texto e o pré-texto, cit., p. 118.
} 
emergir, como, por exemplo, a censura e a imagem do poder contidas na figura do ditador.

Portanto, as questões dos insubmissos que se opõem ao regime, os mecanismos de censura, o discurso do poder, tudo isso pode tanto ser relatado pela história oficial quanto vir a ser tema de enredos fictícios. As narrativas de Cardoso Pires, além de retirarem do esquecimento fatos cruciais da história do Estado Novo português, procuram também interpretá-los, de modo que os enredos históricos se tornem peças fundamentais na transfiguração para uma nova narrativa.

Em Dinossauro Excelentíssimo, o questionar de Cardoso Pires procura desmascarar os fatos encobertos pelo discurso oficial, e, para realizar tal ação, o autor se afasta do "discurso centralizado", buscando a margem para encontrar a história escamoteada. Parece que a tensão existente entre o discurso oficial e o discurso marginal seduz o autor, assim como os narradores cardosianos. A narrativa referida é permeada de intertextos, relacionados aos fatos históricos que remetem à situação política do país ou à biografia de Salazar, caracterizado na fábula como um Imperador-Dinossauro. Essa identificação nos possibilita traçar um paralelo entre características e atitudes do ditador Salazar e as do personagem Imperador.

Nessa fábula de Cardoso Pires, percebemos o trabalho com fragmentos que se misturam para criar um "tom" humano, observamos que existem outras histórias que se misturam a vários gêneros. Examinamos, através de uma leitura vertical, como é possível resgatar as várias vertentes que giram em torno da ditadura: o ditador, a censura, a História, entendendo-as como histórias paralelas, fábulas dentro de fábulas que vêm dissertar e até mesmo descrever o terror que um ditador impõe aos seus súditos.

De traços da biografia de Salazar, destacamos algumas cenas ou temas da narrativa que dialogam com fatos históricos da época do Estado Novo, como a Câmara de Torturar Palavras. Esta pode remeter aos métodos de censura (ou aos espaços de tortura) e fazer uma analogia à ação do lápis azul, porque ele representava o censor e retirava de circulação os textos que criticassem o sistema vigente: era na máquina infernal que o Imperador-Dinossauro mutilava as "palavras". 
Como vimos, na obra de Cardoso Pires há textos que revelam, através da alusão, um plano de construção de efeitos plásticos, que retomam imagens emergentes dos enredos e criam silenciosamente outras histórias. Após as análises realizadas, entendemos que, quando percebidas e alinhavadas, as histórias concretizam ideias abstratas, conceitos que se tornam narráveis a partir da justaposição de pequenos fragmentos de textos alheios, os quais, entrelaçados, formam as imagens concebidas pelo autor, formando um mosaico composto de múltiplas nuanças. Assim, cabe ao leitor decodificar o enigma proposto: qual é a moral dessa fábula? O que, afinal, ela nos ensina? Se há uma moral na fábula de Cardoso Pires, talvez seja a de que, apesar de tudo, haverá sempre uma nova perspectiva a ser descoberta, pois as palavras podem sempre criar novos discursos: "Afinal temos tanto para viver."441

Nesse sentido, acreditamos que o ato de criar enredos de Cardoso Pires pôde afirmá-lo como uma presença arguta no universo da Literatura Portuguesa contemporânea, pois, em pleno processo ditatorial, ele cultivou corajosamente a independência e a liberdade de dizer "não" a qualquer aparelho ditador, ainda que, certas vezes, tenha sido cerceado pela vigilância cerrada em torno de seus escritos.

Para completar a epígrafe destas considerações, citamos novamente Fernando Pessoa: "Em tudo paira a alegria / E, de tão íntima que é, / Como Deus na Teologia / Ela existe em toda a parte / E em parte alguma se vê."

${ }^{441}$ PIRES, José Cardoso. Dinossauro Excelentíssimo, cit., p. 148. 


\section{REFERÊNCIAS BIBLIOGRÁFICAS}

ABDALA JUNIOR, Benjamin. Os cravos de abril e os encontros da história. Revista Novos Rumos. São Paulo: Universidade Estadual Paulista Júlio de Mesquita Filho, ano 16, n. 34, p. 45-50, 2001.

ADORNO, Teodoro W. Notas de Literatura I. São Paulo: Duas Cidades, 2003.

ALVES, Clara Ferreira. José Cardoso Pires. Documentário. Prod. e realiz. Rosa Filmes. Lisboa: RTP, 1998. Disponível em: <http://www.citi.pt/cultura/ literatura/romance/cardoso_pires/>. Acesso em: 10 set. 2010.

APOLLINARE, Guillaume. O bestiário ou cortejo de Orfeu. Trad. e apres. Álvaro Faleiros. Ilustr. Raoult Dufy. São Paulo: Iluminuras, 1997.

ARISTÓTELES. Poética. Trad. Eudoro de Sousa. Lisboa: Imprensa Nacional Casa da Moeda, 1986.

Arte poética e arte retórica. Trad. Antônio Pinto de Carvalho. São Paulo: Ediouro, [s.d.].

; HORÁCIO; LONGINO. A poética clássica. Introd. Roberto de Oliveira Brandão. Trad. direta grego / latim Jaime Bruna. São Paulo: Cultrix, 1997.

AVILÉS, Enrique Turpin. El género de la fábula en los noventa: inflexiones y propuestas. In: CASTILHO, José Romera; CARBAJO, Francisco Gutiérrez. El cuento en la década de los noventa. Madrid: Visor, 2001, p. 729-742.

AZEVEDO, Cândido de. A censura de Salazar e Marcelo Caetano. Lisboa: Caminho, 1999.

Mutiladas e proibidas: para a história da censura literária em Portugal nos tempos do Estado Novo. Lisboa: Caminho, 1997.

BAPTISTA, Diana Maria Silva. Imagens animais nos Sermones horacianos. In: MORA, Carlos de Miguel (Coord.). Sátira, paródia e caricatura: da Antiguidade aos nossos dias. Aveiro: Universidade de Aveiro / Práxis XXI, p. 123-158.

BARTHES, Roland. O rumor da língua. Trad. António Gonçalves. Lisboa: Ed. 70, 1987.

Aula. Trad. e posfácio Leyla Perrone-Moisés. São Paulo: Cultrix, 2002. 
BAUDRILLARD, Jean. Palavras de ordem. Trad. Serafim Ferreira. Porto: Campo das Letras, 2001.

BAUMAN, Zygmunt. Modernidade e ambivalência. Trad. Marcus Penchel. Rio de Janeiro: Jorge Zahar, 1999.

O mal-estar da pós-modernidade. Trad. Mauro Gama e Cláudia Martinelli Gama. Rio de Janeiro: Jorge Zahar, 1998.

Legisladores e intérpretes: Sobre la modernidad, la posmodernidad y los intelectuales. Trad. Horacio Pons. Buenos Aires: Universidad Nacional de Quilmes, 1997.

BELARD, Francisco. Fados vadios. Jornal Expresso. Lisboa, 8 nov. 1997.

BENJAMIN, Walter. Origem do drama barroco alemão. Trad. Sergio Paulo Rouanet. São Paulo: Brasiliense, 1994.

BENTHAM, Jeremy. O panóptico. Org. e trad. Tomaz Tadeu da Silva. Belo Horizonte: Autêntica, 20000.

BÍBLIA. Trad. e notas Ivo Storniolo e Euclides Martins Balancin. São Paulo: Paulinas, 1991.

BOBBIO, Norberto. Os intelectuais e o poder: dúvidas e opções dos homens de cultura na sociedade contemporânea. Trad. Marco Aurélio Nogueira. São Paulo: Ed. Universidade Estadual Paulista, 1997.

BOSI, Alfredo. Fenomenologia do olhar. In: NOVAES, Adauto et al. O olhar. São Paulo: Companhia das Letras, 1988, p. 65-87.

BRIESEMEISTER, Dietrich. A técnica de codificação histórica no romance O Delfim (1968), de José Cardoso Pires. Semear. Rio de Janeiro: Cátedra Padre António Vieira de Estudos Portugueses da PUC-Rio, n. 11, p. 57-83, 2005.

BRIONES, Ana Isabel. Género e contragénero. Tópicos do romance policial na narrativa portuguesa dos anos oitenta como via de reflexão histórica. Revista de Filologia Românica. Madrid: Universidad Complutense, n. 15, p. 267-280, 1998.

BRUNI, Nina. El rol del intelectual en la era de Trujillo en el personero de Efraín Castillo. Cielonaranja. Santo Domingo: Ediciones Cielonaranja, [s. d.]. Disponível em: <http://www.cielonaranja.com/ninabruni.htm>. Acesso em: 11 nov. 2005.

CALVINO, Ítalo. Seis propostas para o próximo milênio: lições americanas. Trad. Ivo Cardoso. São Paulo: Companhia das Letras, 1990. 
Fábulas italianas. Trad. Nilson Moulin. São Paulo: Companhia das Letras, 2005.

Assunto encerrado: discurso sobre literatura e sociedade. Trad. Roberta Barni. São Paulo: Companhia das Letras, 2006.

CANTINHO, Maria João. $O$ anjo melancólico: ensaio sobre o conceito de alegoria na obra de Walter Benjamin. Braga: Angelus Novus, 2002.

CAPRETTINI, G. P. Alegoria. In: Enciclopédia Einaudi 31 Signo. Trad. João Dionísio e Maria Bragança. Lisboa: Imprensa Nacional / Casa da Moeda, 1994.

CARDOSO, Miguel O. de Barros. José Cardoso Pires: um delfim da escrita dialética e transparente. Millenium on-line. Viseu: Instituto Politécnico de Viseu, n. 15, jul. 1999. Disponível em: < http://www.ipv.pt/millenium/15_pers5.htm>. Acesso em: 3 set. 2013.

CELANI, Simone. O devorador de palavras: stadi evolutivi del Dinossauro Excelentíssimo. Status Quaestions. Roma: Università degli Studi di Roma La Sapienza, n. 1, p. 5-23, 2011.

CHAUÍ, Marilena de Sousa. O que é ideologia. São Paulo: Abril Cultural / Brasiliense, 1984.

Cultura e democracia: o discurso competente e outras falas. São Paulo: Moderna, 1982.

. Janela da alma, espelho do mundo. In: NOVAES, Adauto et al. $O$ olhar. São Paulo: Companhia das Letras, 1988, p. 31-63.

CHRISTIN, Anne-Marie. Legível/Visível. Dicionário Crítico de Arte, Imagem. Linguagem e cultura. Lisboa: Centro de Estudos de Comunicação e Linguagens Universidade Nova de Lisboa / UAUM - Unidade de Arqueologia da Universidade do Minho. Disponível em: <http://www.artecoa.pt $/$ index.php? Language $=$ pt $\&$ Page $=$ Saberes $\&$ SubPage $=$ ComunicacaoELinguag emLinguagem \&Menu2=Autores\&Slide=67> . Acesso em: 22 out. 2013.

COELHO, Eduardo Prado. O círculo dos círculos. In: PIRES, José Cardoso. $O$ Delfim. Lisboa: Dom Quixote, 1999, p. 15.

COELHO, Nelly Novaes. José Cardoso Pires - O Delfim: uma obra "aberta". In: Escritores portugueses. São Paulo: Quíron, 1973, p. 154.

COELHO, Nelly Novaes. Literatura infantil. São Paulo: Ática, 1993. 
COMPAGNON. Antoine. O demônio da teoria: literatura e senso comum. Trad. Cleonice Paes Barreto Mourão e Consuelo Fortes Santiago. Belo Horizonte: UFMG, 2001.

CRUZ, Liberto. Análise crítica e seleção de textos. 1. ed. Lisboa: Arcádia, 1972.

CUNHA, Helenice. A rede de palavras e a máscara de Imperador em Dinossauro Excelentíssimo. Dissertação [Mestrado em Letras]. Rio de Janeiro: Pontifícia Universidade Católica do Rio de Janeiro, Departamento de Letras, 2007.

A trama de poder em Dinossauro Excelentíssimo. In: SALEM, Khalil (Org.). Conhecimento, tecnologia e linguagem. São Paulo: Fiuza, 2013. Coletânea Acadêmica de Estudos em Letras e Educação (CAELE), n. 12.

Dinossauro Excelentíssimo no fio da navalha da censura. In: XXII Congresso Internacional da ABRAPLIP - Memória, Trânsitos e Convergências. Anais. Salvador, 2009, p. 1.755-1.767.

O silêncio-pérola dos papéis de Alexandra. In: SALEM, Khalil (Org.). Conhecimento, tecnologia e linguagem. São Paulo: Fiuza, 2013. Coletânea Acadêmica de Estudos em Letras e Educação (CAELE), n 14 (no prelo)

CURTIUS, Ernst Robert. Literatura européia e Idade Média latina. Trad. Teodoro Cabral e Paulo Rónai. São Paulo: Hucitec / EDUSP, 1996.

DÉCIO, João. Uma nova faceta da ficção de José Cardoso Pires. Jornal Letras e Letras. Lisboa, n. 45, 17 abr. 1991, p. 14.

DUFOUR EL-MALEH, Marie-Cécile. Angelus Novus. Essai sur l'oeuvre de Walter Benjamin. Bruxelles: Ousia, 1990.

DIONÍSIO, Mário. Uma pequena grande história. In: PIRES, José Cardoso. $O$ anjo ancorado. Lisboa: O Jornal, 1984, p. 5-45.

D’ONOFRIO, Salvatore. Teoria do Texto 1. São Paulo: Ática, 1995.

DOSSE, François. Uma história em migalhas. In: A história em migalhas: dos Annales à nova história. Trad. Dulce Oliveira Amarante dos Santos. São Paulo: EDUSC, 2003, p. 247-267.

ECO, Umberto. Sobre a literatura. Trad. Eliana Aguiar. Rio de Janeiro: Record, 2003.

Seis passeios pelos bosques da ficção. Trad. Hildegard Feist. São Paulo: Companhia das Letras, 2002. 
Os limites da interpretação. Trad. Pérola de Carvalho. São Paulo:

Perspectiva, 1999.

ENZENSBERGER, Hans Magnus. Cismas portugueses. In: A outra

Europa: impressões de sete países europeus, com um epílogo do ano de 2006. Trad. Isabela Kestler. São Paulo: Cia das Letras, 1988, p. 127-163.

FABRIS, Annateresa. Os folhetins perversos de Max Ernest. Anuário de literatura. V. 15, n. 1, p. 172, 2010.

FALEIROS, Álvaro. Apresentação. In: APOLLINARE, Guillaume. O bestiário ou cortejo de Orfeu. Trad. e apres. Álvaro Faleiros. Ilustr. Raoult Dufy. São Paulo: Iluminuras, 1997.

FEDRO. Fábulas. Trad. Antônio I. de M. Neves. Campinas, SP: Átomo / PNA, 2001.

FIORIN, José Luiz. Língua, discurso e política. Alea. V. 11, n. 1, p. 160, jan./jun. 2009.

FORTE, Isabel. A censura de Salazar no jornal de notícias. Coimbra: Minerva, 2000.

FOUCAULT, Michel. Microfísica do poder. Trad. Roberto Machado. São Paulo: Graal, 2004.

História da sexualidade I: A vontade de saber. Trad. Maria Thereza da Costa Albuquerque e José Augusto Guilhon Albuquerque. São Paulo: Graal, 2003.

A ordem do discurso. Trad. Laura Fraga de Almeida Sampaio. São Paulo: Loyola, 2006.

FRYE, Northrop. O caminho crítico. Trad. Antônio Arnoni Prado. São Paulo: Perspectiva, 1973.

FURLIN, Marcelo. O verbo além da âncora: reflexões sobre o textum em construção de José Cardoso Pires. Reviste Internacional d'Humanitats. Barcelona: CEMOrOC-Fesup / Univ. Autònoma de Barcelona, n. 25, p. 39-48, maio/ago. 2012.

GAGNEBIN, Jeanne Marie. História e narração em W. Benjamin. São Paulo: Perspectiva, 1994. Coleção Estudos, n. 142. 
GAMA, Joaquim Cesar Moreira. Abordagem estética e pedagógica do teatro de figuras alegóricas. Disponível em: <http://www.pos.eca.usp.br/index.php?q=ptbr/book/export/html/4726>. Acesso em: 5 dez. 2012.

GARCÍA, María Jesús Fernández. La novela del ditador Salazar: Dinossauro Excelentíssimo de José Cardoso Pires. Anuário de Estudos Filológicos. Mérida, ESP: Universidad de Extremadura, ano XXIII, p. 123-142, 2000.

Novelas de dictador: puente entre la literatura hispanoamericana y portuguesa. In: ARAGONES, Josefina Prado; RODRIGUES, Maria Amor Pérez; CAMACHO, María Victoria Galloso (Eds.). Un puente entre dos culturas: aproximación a la lengua y cultura hispanolusas. Huelva, ESP: Universidad de Hueva, 2003, p. 187-218.

GARCÍA BERRIO, Antonio. Poética: tradição e modernidade. São Paulo: Littera Mundi, 1999.

GINZBURG, Carlos. Mitos, emblemas, sinais: morfologia e história. Trad. Federico Carotti. São Paulo: Companhia das Letras, 1989, p. 151.

O fio e os rastros: verdadeiro, falso, fictício. Trad. Rosa Freire d'Aguiar e Eduardo Brandão. São Paulo: Companhia das Letras, 2007.

GOMES, Renato Cordeiro. De Ítalo Calvino a Ricardo Piglia, do centro para a margem: o deslocamento como proposta para a literatura deste milênio. Alea: Estudos Neolatinos. Rio de Janeiro: Programa de Pós-Graduação em Letras Neolatinas, Faculdade de Letras da UFRJ, v. 6, n.1, jan./jun. 2004, p. 13-25. Disponível em: <http://www.scielo.br/pdf/alea/v6n1/a02v06n1>. Acesso em: 28 jun. 2006.

GRAMSCI, Antonio. Cadernos do cárcere. Trad. Carlos Nelson Coutinho. Rio de Janeiro: Civilização Brasileira, V. 2, 2000.

GUERREIRO, António. A morte branca. Jornal Expresso. Lisboa, 24 maio 1997.

HANSEN, João Adolfo. Alegoria: construção e interpretação da metáfora. São Paulo: Ed. Unicamp, 2006.

HOBSBAWM, Eric. Era dos extremos: o breve século XX: 1914-1991. Trad. Marcos Santarrita. São Paulo: Companhia das Letras, 1995.

HOUAISS, Antonio; VILLAR, Mauro de Salles. Dicionário Houaiss da Língua Portuguesa. Rio de Janeiro: Objetiva, 2009.

JOÃO ABEL MANTA. In: arte-facto [hereges perversões]. Disponível em: $<$ http://arte-factoheregesperversoes.blogspot.com.br/2011/04/joao-abelmanta.html>. Acesso em: 10 out. 2013. 
KOTHE, Flávio R. A alegoria. São Paulo: Ática, 1986.

LA FONTAINE (Jean de La Fontain). Fábulas. Trad. Monteiro Lobato. São Paulo: Brasiliense, 1966.

Introdução: Estudos Críticos. In: Fábulas de La Fontaine. Lisboa: Moderna Editorial Lavores, 2001, p. 5.

LAUSBERG, Heinrich. Elementos de retórica literária. Trad., prefácio e aditamento R. M. Rosado Fernandes. 5. ed. Lisboa: Calouste Gulbenkian, 2004.

LE GOFF, Jaques. Os intelectuais da Idade Média. Trad. Marcos de Castro. Rio de Janeiro: José Olympio, 2003.

A bolsa e a vida: economia e religião na Idade Média. Trad. Rogério Muoio. São Paulo: Brasiliense. 2004.

LEPECKI, Maria Lúcia. Ideologia e imaginário: ensaio sobre José Cardoso Pires. Lisboa: Moraes, 1977.

Delfins, corvos e dinossauros: interseções discursivas em José Cardoso Pires. Scripta. Belo Horizonte: / Programa de Pós-Graduação em Letras Departamento de Letras da PUC-Minas / Centro de Estudos Luso-AfroBrasileiros (CESPUC-MG), v. 7, n. 14, p. 202-207, 1. sem. 2004.

LICHTENSTEIN, Jacqueline (Org.). A pintura. Coord. de trad. Magnólia Costa. Apres. Jean-François Groulier. São Paulo: Ed. 34, V. 8, 2005.

LOPES, Óscar. Depoimento. Público. Lisboa, 27 out. 1998.

LOURENÇO, António Apolinário. A arte de ser português. Jornal de Letras, Artes e Ideias. [s. 1.], n. 285, 21 dez., p. 22.

LOURENÇO, Eduardo. O labirinto da saudade: psicanálise mítica do destino português. Lisboa: Dom Quixote, 1982.

Portugal como destino: dramaturgia cultural portuguesa. In:

Mitologia da saudade seguido de Portugal como destino. São Paulo: Companhia das Letras, 1999, p. 97.

MACHADO, Roberto. Introdução. In: FOUCAULT, Michel. Microfísica do poder. Trad. Roberto Machado. São Paulo: Graal, 2004.

MAILER, Phil; BRINTON, Maurice. Portugal: a revolução impossível? Porto: Afrontamento, 1978. 
MANGUEL, Alberto. Lendo imagem: uma história de amor e ódio. Trad. Rubens Figueiredo, Rosaura Eichemberg e Claúdia Strauch. São Paulo: Companhia das Letras, 2001.

MARGATO, Izabel. Fumar ao espelho: relações, posicionamento, citações. In: ; GOMES, Renato Cordeiro (Orgs.). Espécie de espaços: territorialidades, literatura e mídia. Belo Horizonte: Ed. UFMG, 2008.

Narrar para viver, seduzir e desencantar. A situação da narrativa no início do século XXI: saudades de Sherazade? Seminário. Semear. Rio de Janeiro: Cátedra Padre Antonio Vieira de Estudos Portugueses da PUC-Rio, n. 7, p. 265275, 2002.

O intelectual em tempos difíceis. In: ; GOMES, Renato Cordeiro (Orgs.). O papel do intelectual hoje. Belo Horizonte: Ed. UFGM, 2004, p. 154.

Os procedimentos de escrita de José Cardoso Pires. Revista Via Atlântica. São Paulo: Faculdade de Filosofia, Letras e Ciências Humanas da USP, n. 9, p. 196, jun. 2012.

; GOMES, Renato Cordeiro (Orgs.). O papel do intelectual hoje. Belo Horizonte: Ed. UFMG, 2004.

MARIANO, Juliano Camargo. A literatura infantil e o autoritarismo no século XX: um estudo comparativo entre Ruth Rocha e José Cardoso Pires. Dissertação de Mestrado. São Paulo: Faculdade de Filosofia, Letras e Ciências Humanas da USP, 2012.

MARQUES, Antonio Henrique R. de Oliveira. Breve história de Portugal. Lisboa: Presença, 1998.

MARTINS, Guilherme d'Oliveira. José Cardoso Pires: pedagogo da vida. Jornal de Letras. [s. 1.], 27 nov. 2002.

ERNST, Max - Uma semana de bondade, MASP, SP. Revista Museu. Disponível em: <http://www.revistamuseu.com.br//naestrada/naestrada.asp?id=23636>.

Acesso em: 25 out. 2010.

MAXWELL, Kenneth. A construção da democracia em Portugal. Lisboa: Presença, [s.d.].

METZGER, Bruce M.; COOGAN, Michael D. (Orgs.). Dicionário da Bíblia: as pessoas e os lugares. Trad. Maria Luiza X. de A. Borges. Rio de Janeiro: Jorge Zahar, V. 1, 2002. 
MILLER, Jacques-Alain. A máquina panóptica de Jeremy Bentham. Trad. M. D. Magno. In: BENTHAM, Jeremy. O panóptico. Org. Tomaz Tadeu da Silva. Belo Horizonte: Autêntica, 2000, p. 77-107.

MURICY, Kátia. Os olhos do poder. In: NOVAES, Adauto et al. O olhar. São Paulo: Companhia das Letras, 1988, p. 483.

NASCIMENTO, Manuel do. Encontro com Cardoso Pires. O Primeiro de Janeiro. Lisboa, 28 set. 1958, p. 58.

NOVAES, Adauto et al. O olhar. São Paulo: Companhia das Letras, 2006.

OLIVEIRA, Francisco de. Intelectuais, conhecimento e espaço público. In: MORAES, Dênis de (Org.). Combates e utopias. Rio de Janeiro: Record, 2004, p. $55-67$.

PAIS, Amélia Pinto. Fernando Pessoa, o menino de sua mãe. São Paulo: Companhia das Letras, 2009.

PALHA, Victor. Caricatura de José Cardoso Pires. In: LEPECKI, Maria Lúcia. Ideologia e imaginário: ensaio sobre José Cardoso Pires. Lisboa: Moraes, 1977, p. 181.

PAZ, Otávio. Signos em rotação. Trad. Sebastião Uchoa Leite. Org. e rev. Celso Lafer e Haroldo de Campos. São Paulo: Perspectiva, 2006. Coleção Debate, n. 48.

PÉCORA, Antonio Alcir Bernárdez. O demônio mudo. In: NOVAES, Adauto et al. O olhar. São Paulo: Companhia das Letras, 1988, p. 304.

PEREIRA, Luciano. A fábula, um género alegórico de proverbial sabedoria. Forma Breve - Revista de Literatura: A Fábula. Aveiro: Universidade de Aveiro, n. 3, 2005, p. 22-32. Disponível em: <http://revistas.ua.pt/index.php/formabreve>. Acesso em: 8 ago. 2013.

PETERLE, Patrícia. O fio da navalha. Jornal Rascunho: ensaio e resenha. Curitiba: Gazeta do Povo, n. 137, set. 2011.

PETROV, Petar. O realismo na ficção de José Cardoso Pires e de Rubem Fonseca. Lisboa: Difel, 2000.

O ensaio na obra de José Cardoso Pires. GridHoster.com. [s.1.]: [s.d.]. Apoio Instituto Camões / Fundação para a Ciência e a Tecnologia. Disponível em: <http://www.geocities.ws:ail_br:oensaionaobradejosecardoso.htm\%20>. Acesso em: 7 out. 2012. 
PFROMM NETTO, Samuel. Prefácio. In: FEDRO. Fábulas. Trad. Antônio Inácio de Mesquita Neves. Campinas, SP: Átomo / PNA, 2001, p. 4.

PIGLIA, Ricardo. Tres propuestas para el próximo milenio (y cinco dificultades). Conferência. Havana: Casa de las Américas, 2000. Boletin CCyDEL. Mexico: Centro Coordinador y Difusor de Estudios Latinoamericanos (CCyDEL) - atual Centro de Pesquisas sobre a América Latina e o Caribe (CIALC) - Universidade Nacional Autônoma do México, año XLI, n. 222, Enero/Marzo 2001. Disponível em: 〈http://www.ccydel.unam.mx/BOLETIN/ boletin_6_7/revistas/casa222.htm>. Acesso em: 8 maio 2013.

. Crítica y ficción. Barcelona: Anagrama, 2001.

Formas breves. Trad. José Marcos Mariani de Macedo. São Paulo: Companhia das Letras, 2004.

Ler errado é muito produtivo. Entrevista concedida a Julián Fuks. Revista Entrelivros. São Paulo: Duetto, ano 2, n. 21, p. 17, jan. 2007.

O laboratório do escritor. Trad. Josely Vianna Baptista. São Paulo: IIuminuras, 1994.

2006.

O último leitor. Trad. Heloisa Jahn. São Paulo: Companhia das Letras,

PIRES, José Cardoso. A república dos corvos. Lisboa: Dom Quixote, 1989.

Alexandra Alfa. Lisboa: Dom Quixote, 1999.

Balada da Praia dos Cães: dissertação sobre um crime. Rio de Janeiro: Civilização Brasileira, 1983.

Dinossauro Excelentíssimo. [Ilustrações de João Abel Manta.] 5. ed. Lisboa: Bertrand, 1973.

. Dinossauro Excelentíssimo. Lisboa: Dom Quixote, 1999.

Dispersos 1. Lisboa: Dom Quixote, 2005.

E agora, José? Lisboa: Dom Quixote, 1999.

Entrevista ao Diário de Notícias. Lisboa, 11 jun. 1997.

O anjo ancorado. Lisboa: O Jornal, 1984. 
O burro em pé. Alfragide: Leya, 2010.

O Delfim. Lisboa: Dom Quixote, 1998.

PORTELA, Arthur. Cardoso Pires por Cardoso Pires. Lisboa: Dom Quixote, 1991.

RAMOS, Rui. Os intelectuais e o Estado Novo. Disponível em: <http://www.ciberkiosk.pt/arquivo/ciberkiosk8/ensaios/intelectuais.html>. Acesso em: 25 out. 2012.

RANCIÈRE, Jacques. A partilha do sensível: estética e política. Trad. Monica Costa Netto. São Paulo: Ed. 34, 2005.

REIS, Carlos. Para una semiótica de la ideologia. Madrid: Taurus, 1987.

; LOPES, Ana Cristina M. Dicionário de teoria da narratividade. São Paulo: Ática, 1988.

REVEL, Judith. Michel Foucault: conceitos essenciais. Trad. Carlos Piovezani Filho e Nilton Milanez. São Carlos, SP: Claraluz, 2005.

RIBEIRO, Antonio Souza. Configurações do campo intelectual português no pós25 de Abril: o campo literário. In: SANTOS, Boaventura de Sousa (Org.). Portugal: um retrato singular. Porto: Afrontamento, 1993, p. 483-512.

RIBEIRO, Fernando. Lessing: arte popular culta. In: Acta do IV Congresso Internacional da Associação Portuguesa de Literatura Comparada. Estudos Literários/Estudos Culturais, V. 2: Tradução, tradições e cânones. Lisboa: Universidade Nova de Lisboa, 2001. Disponível em: <http://www. eventos.uevora.pt/comparada/VolumeII/LESSING.pdf>. Acesso em: 12 jul. 2013.

ROCHA, Clara. A memória literária da ditadura: autoridade, identidade, liberdade. Ipotesi: Revista de Estudos Literários. Juiz de Fora: Programa de PósGraduação em Letras da UFJF, V. 7, n. 2, p. 29-39, 2003.

. Para uma leitura dos "contos exemplares". Máthesi. Viseu: Universidade Católica Portuguesa, n. 10, 2001.

RODRIGUES, Graça Almeida. Breve história da censura literária em Portugal. Lisboa: Bertrand, 1980. Biblioteca Breve, v. 54.

ROSAS, Fernando. História de Portugal: o Estado Novo (1926 - 1974). Lisboa: Estampa, 1998. 
ROUANET, Sergio Paulo. Apresentação. In: BENJAMIN, Walter. Origem do drama barroco alemão. Trad., apres. e notas Sérgio Paulo Rouanet. São Paulo: Brasiliense, 1984, p. 215.

SAID, Edward W. Representações do intelectual. Palestras de Reith de 1993. Trad. Teresa Seruya. Lisboa: Colibri, 2000.

SALAZAR, António. Discurso. Disponível em: <http://www.geocities.com/ CapitolHill/Lobby/ 6559/fonseca.html>. Acesso em: 8 ago. 2013

SAMPAIO, Maria de Lurdes Morgado. As margens no centro: lugares de desatenção na obra de José Cardoso Pires. In: MORUJÃO, Isabel; SANTOS, Zulmira C. (Coords.). Literatura culta e popular em Portugal e no Brasil: homenagem a Arnaldo Saraiva. Porto: Cia das Artes, 2011, p. 246-258.

José Cardoso Pires das Neves. In: Base Ulyssei@s: escritores e outros criadores em deslocação. Porto: Instituto de Literatura Comparada Margarida Losa. Disponível em: 〈http://www.ilcml.com>. Acesso em: 3 ago. 2013.

SANTIAGO, Silviano. O intelectual modernista revisitado. In: Nas malhas da letra. São Paulo: Companhia das Letras, 1989, p. 193-205.

SANTOS, João de Almeida. Os intelectuais e o poder. Lisboa: Fenda, 1999.

SARAIVA, António José. História da literatura portuguesa. 12. ed. Porto: Porto Ed., [s. d.].

SARTRE, Jean-Paul. Em defesa dos intelectuais. Trad. Sérgio Góes de Paula. São Paulo: Ática, 1994.

SCOTT, Ana Silva. Os portugueses. São Paulo: Contexto, 2010.

SEIXO, Maria Alzira. Dez anos de ficção em Portugal (1974-1984). In: . A palavra do romance: ensaios de genologia e análise. Lisboa: Horizonte, 1986, p. 48-65.

SERRÃO, José (Dir.). Dicionário de História de Portugal. Porto: Figueirinhas, 2000, V. 8, p. 281-289.

SOUSA, Manuel Aveleza. Origens, conceitos e evolução do gênero fábula. Calíope. Rio de Janeiro: 7 Letras, n. 10, p. 68-76, dez. 2001.

TORGAL, Luís Reis. O Estado Novo: salazarismo, fascismo e Europa. In: MATOSSO, José et al. História de Portugal. São Paulo: UNESP, 2001, p. 391415. 
TORRADO, António. Milhões de livros, biliões de vozes. Conto e Reconto: As Fábulas. Boletim Cultural. Lisboa: Calouste Gulbenkian, Série VIII, n. 2, p. 7, maio 1996.

VOGT, Carlos. Paisagem doméstica. São Paulo: I. Guarnelli / Massao Ohno, 1984. Série Almanaque do Pensamento.

VUILLEMIN, André. Ditador. In: BRUNEL, Pierre (Org.). Dicionário de Mitos Literários. Rio de Janeiro: José Olympio, 2000.

WINOCK, Michel. O século dos intelectuais. Trad. Eloá Jacobina. Rio de Janeiro: Bertrand Brasil, 2000. 
ANEXOS 


\section{Anexo 1}

\section{José Cardoso Pires: A censura fez-nos viver num país alienado ${ }^{442}$}

"Julgar a Censura, no sentido da avaliação do que ela representou de negativo para a cultura portuguesa, a duas décadas e meia da queda do Estado Novo..., pois eu diria que a Censura foi uma polícia do espírito, numa política que se dizia do espírito, quando, na realidade, a Censura era o maior inimigo dos espíritos" - começou por nos dizer José Cardoso Pires, no depoimento solicitámos sobre a experiência nesta matéria.

A este respeito, - prossegue José Cardoso Pires - a Censura foi, sem dúvida, uma das armas mais importantes que Salazar teve à sua disposição, e que nos fez viver, literalmente, num país alienado.

$\mathrm{Eu}$, como muitos outros, naquela altura, com a Censura e com passaportes altamente vigiados, e condicionados, pela polícia política, sentíamo-nos isolados do mundo, sós - mas não "orgulhosamente sós”, porque assim é como se sentia Salazar. Nós, pelo contrário, sentíamo-nos, sim, mas era tristemente sós, porque isolados do resto do mundo. Daí uma série de anedotas que se contavam naquela época, do género: se queres saber o que se passa em Portugal compra o Le Monde, e coisas assim, que, aliás, correspondiam à realidade, porque nós só sabíamos um certo número de coisas, através da imprensa estrangeira.

Eu devo dizer que não fui vítima especial da Censura, como o foram outros, por exemplo, o Alves Redol - esse, sim, em determinado período, foi a besta negra da Censura, como o foi também Tomás da Fonseca, por exemplo.

Avaliar até que ponto é que a Censura limitou a minha atividade literária, é difícil dizer. Mas é claro que limitou, porque eu nunca me censurava, nem sequer

\footnotetext{
${ }^{442}$ Depoimento de José Cardoso Pires sobre a censura. "Este depoimento resultou de várias conversas com José Cardoso Pires (que conhecíamos pessoalmente desde 1965), no decorrer de alguns encontros que tivemos entre Outubro de 1997 e princípios de 1998 (Cardoso Pires ia então nos 72 anos de idade, mas mantinha a frescura da irreverência de espírito que sempre the conhecêramos). Esses encontros, por vezes espaçados de algumas semanas, por dificuldades de agenda de Cardoso Pires, realizavam-se quer em sua casa, em Lisboa, quer na Pastelaria Mourisccas, nas Av. Fontes de Melo, igualmente em Lisboa." (AZEVEDO, Cândido de. Mutiladas e proibidas: para a história da censura literária em Portugal nos tempos do Estado Novo. Lisboa: Caminho, 1997, p. 109).
} 
isso me passava pela cabeça. Eu tenho esta idade que tenho, e publiquei para aí um terço ou um quarto dos livros que alguns escritores da minha idade publicaram, com, por exemplo, Urbano Tavares Rodrigues, que tem para aí três ou quatro vezes mais livros publicados do que eu.

É óbvio que numa situação diferente, totalmente diferente, sem fascismo, em liberdade, possivelmente teria escrito mais, mas isso também depende das pessoas, é evidente.

Em relação a contactos directos com a Censura, isto é, a conversas com censores, nunca as tive, exceptuando uma só vez, em 1952, por causa da publicação do meu segundo livro, Histórias de Amor, que foi proibido.

Nem mesmo quando colaborava em jornais. Nessa altura tinha aquelas experiências que tinham todos, mas nunca era eu que tratava directamente com a Censura, e foi aí que apercebi claramente, que a polícia da escrita estava atenta aos novos escritores, foi quando saiu uma antologia universitária, intitulada, Bloco, onde eu colaborei com um conto, Salão de Vintém, e que foi apreendida de imediato. Eu entro nessa antologia do Bloco, que era dirigida pelo Mário Ruivo (que é, ainda hoje, o homem mais conhecido da nossa investigação ligada às pescas e aos mares), meses antes da publicação daquele meu livro, História de Amor.

Essa foi, realmente, a primeira vez que senti a Censura. Mas nem então nem quando publiquei o meu primeiro livro, Os Caminhoneiros e Outros Contos, igualmente apreendido pela PIDE, tive contatos directos com a Censura. Nunca os tive, não ser uma só vez, como disse em 1952, por causa da publicação do meu segundo livro, Histórias de Amor.

O livro saiu com aquele título propositadamente, diria mesmo ingenuamente até, mascarado de histórias de amor, como se fosse uma coisa sem sentido algum, uma coisa ligeira.

Eu sou preso no dia seguinte ao da publicação deste livro. Fui preso por dois agentes da PIDE, que me conduziram de táxi para a António Maria Cardoso, quer dizer, para a sede da polícia política. Recordo-me que me perguntaram se eu pagava o táxi. Disse-lhes que não. Preferia ir a pé. Acabámos por ir de táxi para a António Maria Cardoso, mas foram eles que pagaram. 
Lá fiquei retido durante dois dias, ou seja, uma tarde, uma manhã, mais um dia todo e uma boa parte da noite, pois só me libertaram às três horas da madrugada. Durante aquele tempo todo em que estive preso, o que se passou foi que me puseram numa sala, sozinho, horas e horas, impedido de dormir, sem saber o que me ia acontecer, ou quando seria interrogado - o que, aliás, era a prática que eles adoptavam usualmente, por forma a criar no detido uma certa expectativa, uma forma de stress, que era evidentemente para provocar o efeito que eles queriam obter, isto é: o enfraquecimento psicológico do preso.

Entretanto, por aquela sala em que me encontrava, sozinho, passavam por lá, com muita frequência, aos pares, agentes da PIDE, com um exemplar do meu livro na mão, e faziam-no como ali. Passavam dizendo um para o outro: “Ouve lá, vê isto aqui, parece que há uma coisa que tem a ver com a gente; diz que nós, não sei quê, que prendemos uns tipos... Isto até é muito engraçado.” E lá saíam. Dali a pouco, vinham outros, dizendo coisas semelhantes. Esta cena repetiu-se inúmeras vezes, manifestadamente para me criarem um clima de pânico e de irritação, por forma a que, como já referi, ficasse psicologicamente perturbado.

No final de tudo isto, fizeram-me apenas um interrogatório que consistiu nisto: "Declara-se autor deste livro? Toma a responsabilidade do que está aqui dito, evidentemente. Diga lá seu nome e morada.” E mais nada.

Quer dizer: eu entendi aquilo como sendo, para eles, uma questão menor, como um processo em que eles procuravam apenas aterrorizar-me e, ao mesmo tempo, aterrorizarem a juventude que escrevia naquela época, que estava a começar a escrever e a publicar os seus trabalhos.

Depois, começa uma segunda parte, essa sim, curiosa, que é o da censura propriamente dita. Aí, eu tive conhecimento directo com a Censura. Em determinada ocasião fui chamado à Direcção da Censura. Quem me recebeu foi o homem que na época, era o diretor, o major David dos Santos, e que, segundo constava, tinha estado em África, onde teria cometido as maiores atrocidades possíveis, inclusivamente falava-se que teria queimado vivo um preto, porque o preto teria sido amante da mulher dele. Quem contava essa história já morreu, era o Castro Soromenho, que estava em África nessa altura, e não era pessoa para inventar histórias dessas. 
Seja como for, esse tal major David dos Santos era uma figura curiosa. Só falei com ele uma vez. Foi uma conversa longa. Ele fazia tranquilo o que faziam muitos censores portugueses, que era procurarem transmitir-nos a ideia de que a Censura era paternalista. Dizia-me ele que, ao contrário do que nós pensávamos, a Censura não pretendia acabar com a literatura, o que pretendia era que ela não fosse tão agressiva como o estava a ser, porque isso desmoralizava a Nação. E acrescentava que para as pessoas cultas e ricas, a literatura se fazia em Portugal, com aquelas insinuações e ataques ao regime, não fazia diferença, porque essas pessoas eram cultas e percebiam que o escritor ao escrever um livro não estava propriamente a fazer política, mas apenas a retratar uma figura, até era preciso dizer mal da situação em que o país estava. Essas pessoas, cultas e ricas, percebiam - dizia aquele diretor da Censura - que o escritor escrevia não contra o país em si, contra uma situação grave que o país atravessava, mas enfim contra umas figuras que personalizavam comportamentos eventualmente criticáveis. O problema, concluía o major, é que os pobres, que constituíam a maioria da Nação, não tinham essa capacidade de discernir, e viam nesses livros um incitamento à revolta. E isso é que eles não queriam que acontecesse. Esta era a teoria do então director da Censura, do major David dos Santos.

Nessa única conversa que tive com um censor, ele trouxe-me um exemplar, censurado, com o célebre lápis azul da censura - exemplar que eu tenho em meu poder -, daquele meu livro Histórias de Amor, onde verifiquei que eles cortaram, logo a abrir, a palavra "nu", numa frase que começa assim: "estava nu em cima da cama...”. Bastou-me ver isto para perceber que havia ali um propósito de queimar tudo e mais alguma coisa, pois se logo à cabeça do livro cortavam a segunda palavra, o adjectivo "nu”! E foi de facto o que aconteceu: o lápis azul não se ficou por ali e foi cortando a eito certas expressões como, por exemplo, "filho da mãe", "dor de corno", "catano" e outras do género. Foram todas riscadas, todas excomungadas. Aliás, a simples referência ao Élaurd e ao Pessoa (ao Fernando Pessoa, imagine-se só!), foram simplesmente abaixo. Mas havia páginas eliminadas por inteiro.

O major David dos Santos passou-me para as mãos o exemplar, censurado, desse meu livro - foi tão estúpido quanto isso! - e disse-me: "Você leva o livro por uns dias; pense na nossa conversa e veja se torneia algumas passagens do 
livro." Ou seja: o que ele queria era que eu próprio me autocensurasse. É evidente que eu nunca faria isso. E como o major não marcou um prazo exacto, eu nada fiz. Mas guardei aquele exemplar do meu livro censurado. Constatei, então, que os cortes eram tantos que o texto estava todo esfrangalhado. Seria necessário escrever um livro novo, porque eu nunca seria capaz de me autocensurar. Deus me livre. Conclusão: não pensei mais no assunto, mas pensei que precisava de ficar com aquele exemplar. E assim fiquei à espera, a ver em que é que paravam as modas.

Passados uns tempos, sou chamado de novo à Censura. Lá fui, preparado para lhes dizer: eu não reescrevo nada, tome lá o livro, acabou-se.

Dessa vez, porém, não fui recebido pelo major David dos Santos, mas sim por um outro tipo da Censura, que já não sei quem era, que me disse que me tinha chamado apenas porque havia uma anotação na agenda a dizer que eu ficara em devolver um livro, e, portanto, eles queriam o livro. Eu respondi-lhe que já não sabia onde o tinha mas que o ia procurar e que o devolveria o mais rapidamente possível.

Acontece que, passados uns dias, venho a saber que o major David dos Santos, mais aquele tipo que me recebera da última vez e não sei mais quem, tinham deixado a Censura.

Obviamente que não mais me preocupei com a devolução do exemplar censurado do meu livro Histórias de Amor. Até hoje.

Para se avaliar os estupores que eram aquela gente, censores e pides, repare-se nisto: eles foram à tipografia, que era uma tipografia pequena, que havia ali ao pé do Instituto de Medicina Legal, chamada Severo Freitas Pega, proceder à apreensão da edição do livro - seriam aí uns dois mil exemplares -, o que fizeram rasgando os livros a eito, antes de os deitarem fora.

O que aconteceu é que houve alguém, suponho que foi um dos sócios da tipografia, que, quando viu aquilo, ainda conseguiu guardar meia dúzia de exemplares que estavam mais escapatórios, e tempos depois deu-mos. Ainda tenho um ou dois desses exemplares. 
Mais tarde, já não era o jovem que era quando escrevi Histórias de Amor, tive outras experiências com a Censura, e até mais curiosas, como aconteceu com meu livro Dinossauro Excelentíssimo.

Eu escrevi esse livro para o Natal de 1972 de uma filha minha, a Ritinha, a minha filha mais nova.

O Dinossauro Excelentíssimo era o retrato grotesco de Salazar, era óbvio. Os desenhos de João Abel Manta, que ilustram o livro, mostram-no bem.

Nessa altura, pensei logo que não podia apresentar esse livro ao meu editor, que era a Morais, ao qual eu estava ligado por um contrato que o obrigava a publicar todos os livros que eu escrevesse. Porque não queria que fechassem a editora pensei, então, em fazer uma edição minha, pago com dinheiro meu. O João Abel Manta ofereceu-se logo para ilustrar o livro. De repente, porém, descobri que havia uma editora, que eu conhecia muito bem, onde tinha vários amigos, a Arcádia, que estava falida. Levei o livro à Arcádia e apresentei-o ao Dias de Carvalho, que era um homem muito simpático, e disse-lhe: "Vocês não têm nada a perder, a única coisa que pode acontecer é eu ir preso." (outras pessoas que estavam, na altura, ligadas àquela editora, eram Fonseca e Costa e Cruz Barreto, um advogado). Eles, como estavam falidos - há muito tempo que estavam para fechar -, aceitaram o Dinossauro. E assim foi que o Dinossauro Excelentíssimo foi editado pela primeira vez.

Recordo-me que houve tipografias que se recusaram a imprimir aquele livro, com receio de represálias, que aliás podiam ser muito sérias, até que, finalmente, encontrou-se uma tipografia nova, que ficava na Calçada de Carriche, que aceitou imprimir o livro. Nunca vi tipógrafos tão interessados em compor um livro. O Dinossauro Excelentíssimo veio para a rua numa tiragem de 3000 exemplares, o que, para a época, era já uma boa tiragem.

Eu vivia, então, na Inglaterra, onde lecionava Literatura Portuguesa e Brasileira no King's College da Universidade de Londres, e encontrava-me de férias em Lisboa. O problema que me coloquei, a mim próprio, quando escrevi o Dinossauro, foi este: fico em Portugal ou continuo na Inglaterra?

Continuar aqui, com a Censura e a PIDE, depois de ter tratado Salazar como o tratei naquele livro, de uma maneira realmente muito forte, como ninguém 
nunca o tinha feito, seria realmente uma estupidez, pois acabaria por ir para a prisão de Caxias.

Quando regressei de Londres, para participar na apresentação de Dinossauro, eu receava o pior, e o editor também, embora este já tivesse adoptado algumas precauções para obstar a uma possível proibição da Censura. Eu estou convencido que aí, sim, as coisas podiam ter mudado de figura para mim. Valeume o facto de, entretanto, ter ocorrido uma polémica terrível, um escândalo monumental, pouco depois da saída do livro, na então chamada Assembleia Nacional, em que o deputado ultrafascista Casal Ribeiro cita justamente, a publicação do Dinossauro Excelentíssimo para demonstrar a existência de liberdade em Portugal! ...

Esse escândalo ia alterar muita coisa em relação ao livro, e de certo modo, também em relação a mim próprio.

Estávamos em fins de Novembro de 1972, quando numa sessão da Assembleia Nacional, o professor Miller Guerra, que era deputado da chamada "Ala Liberal" e o Cazal Ribeiro, que era um nazi da pior espécie, se envolveram numa polémica que causou grande sensação. A polémica despoletou-se quando o Miller Guerra denunciou, numa intervenção, a falta de liberdade de imprensa em Portugal, defendendo que era preciso aliviar um pouco a Censura, porque o país precisava de mais liberdade.

O Cazal Ribeiro, coitado, que era um idiota, mas tenebroso, perdeu a cabeça, e interrompeu o Miller Guerra para lhe perguntar se ainda queria mais liberdade do que a que exista - segundo ele - , naquele momento, quando se permitia, disse - dando como exemplo - "a saída de um livro ignóbil, chamado Dinossauro Excelentíssimo.”

O Miller não se amedrontou e respondeu ao Casal Ribeiro que, por ele, "tomara que houvesse muitos Dinossauros e muitos livros que circulassem livremente.".

Bom, aquilo deu azo a uma terrível luta verbal entre os dois, e provocou um estrondo enorme cá fora, porque os jornais República e Diário de Lisboa publicaram o relato da sessão. A Censura deixou passar aquela polémica porque o Cazal Ribeiro, em resposta ao Miller Guerra, disse que se Portugal fosse um país 
sem liberdade, não deixava andar por aí um livro que insultava o nosso Presidente Salazar, perguntando-lhe se ainda queria mais liberdade do que essa.

Eu, quando vi aquilo, disse para comigo: alto, que a partir disto o livro já não pode ser apreendido, pois se o tipo apresentou como prova da existência de liberdade em Portugal a circulação, sem problemas, do Dinossauro Excelentíssimo, eles não podem agora fazer o contrário, porque estariam a desdizer-se completamente, e isso seria muito grave. E assim, aconteceu, o livro não foi apreendido.

Na sequência desse escândalo, ponderei a situação muito bem e decidi jogar tudo por tudo. E fiquei.

Mas houve um outro factor que me fez, também, decidir por ficar em Portugal. O João Abel Manta tinha-se-me oferecido para ilustrar o Dinossauro Excelentíssimo, e se ele corria o risco de ficar por cá, é óbvio que eu não podia voltar para a Inglaterra. De maneira que fiquei em Lisboa. Felizmente, para mim, tive tanta sorte que aconteceu aquele escândalo na Assembleia Nacional.

Eu chamei àquilo que recebi desse estúpido do Cazal Ribeiro o meu "peru de Natal". Com efeito, dois dias apenas após a saída do livro, a edição esgotou-se. A partir de então, o Dinossauro Excelentíssimo passou a fazer edições de 5000 exemplares de cada vez. Fizeram-se várias edições, cerca de dez. Foi um êxito espantoso. Havia pessoas que entravam nas livrarias à procura do "livro da Assembleia”, porque nem sabiam o nome do livro.

Finalmente, dessa vez, pelo menos de imediato, nada me aconteceu a mim, nem àquele meu livro, nem à Arcádia. Ou melhor: em relação à Acardia, aconteceu que arrecadou muito dinheiro e pôde recuperar do estado de falência em que se encontrava, antes de publicar meu livro.

Entretanto, eu nessa época tinha um amigo que morava na Ericeira, onde possuía uma casa, uma casa pequenina, mas muito simpática, na rua dos bombeiros, onde eu ia com alguma frequência. De tempos a tempos, metia-me no carro e ia até Ericeira, para essa casa, onde encontrava a tranquilidade de que precisava para escrever.

Um dia, estava eu num café que lá havia, a tomar uma bica - isto era no Inverno, a Ericeira estava meia deserta -, quando surgem dois tipos em pleno 
café. Sentaram-se junto a mim, um de cada lado. Inesperadamente, sem nada dizerem, atacaram-me, espancando-me violentamente, a pontapé e com umas matracas. Eram agentes da PIDE, ao serviço do tal Cazal Ribeiro, a que me referi há pouco.

Claro que eu defendi-me como pude, mas não me foi fácil, porque eles não usaram armas brancas nem de fogo, mas usaram bastões, uns bastões curtos, e atacaram-me de surpresa e violentamente.

Houve, como é natural, muito alarido entre os empregados e algumas pessoas que entretanto surgiram, e eles foram-se embora. Isto é uma história de Censura que acaba assim, já não com o lápis azul ou com cortes ou proibições, mas à bastonada.

O Cazal Ribeiro era um grande senhor dali, tinha lá uma propriedade ou coisa assim, e aqueles agentes da polícia política eram vistos, frequentemente, numa casa que ficava em frente do posto de gasolina, sempre que o Cazal Ribeiro lá estava.

Também por essa altura, a Bertrand propôs-se fazer uma nova edição do Dinossauro Excelentíssimo, ainda com maior tiragem. Estava então ligado à administração da Bertrand - e digo estava ligado, porque não sei exatamente qual era o papel dele ali -, o Sr. Luka, que me tinha pedido, por intermédio de um amigo meu lá da Bertrand, o Antônio Martins Ramos, para fazer essa edição. Fezse uma reunião em que participaram os administradores, incluindo aquele senhor Luka, e o António Martins Ramos - mas houve mais gente que assistiu ou que sabe da história, como é o caso do Artur Portela -, e, em determinado momento da reunião, quando o livro foi apresentado em cima da mesa, houve um tipo que se indignou, dizendo qualquer coisa do género: "Isso nunca, isso só desprestigia a casa. É uma ofensa ao senhor Presidente do Conselho." Esse senhor chama-se Luiz Forjaz Trigueiros... Este é um dos casos de censura que mais me violentou, porque partiu de um tipo que se diz e até gosta muito de passar por escritor - um escritor menor, mas muito menor, e a prova disso é que, coitado, literariamente não existe, escreveu um livreco ou dois. Foi este fulano que através daquele acto de censura, um acto cobarde, impediu que a Bertrand concretizasse a edição que se propunha fazer daquele meu livro. E isso não lhe perdoo, porque foi um acto de censura, e todos os actos de censura são indignos. 
A Censura foi, aliás, a coisa mais miserável que tivemos durante o fascismo.

Já me referi há pouco a um tal senhor Luiz Forjaz Trigueiros como exemplo significativo de uma censura paralela, constituída por autênticos denunciantes, cuja existência era indiscutível. Mas denunciantes, na época, não falavam. Recordo-me, por exemplo, que quando da publicação do Dinossauro Excelentíssimo, havia um general Câmara Pina que, com mais uns velhinhos frequentadores do Chiado, andavam pelas livrarias da Baixa em acções de denúncia e de intimidação junto dos empregados das livrarias, para que o livro fosse retirado das montras. A verdade é que a censura tinha muitos rostos.

Foi por esta altura também, coincidindo com a publicação do Dinossauro, que eu publiquei meu ensaio Técnica do Golpe de Censura. Esse ensaio apareceu, simultaneamente, no $\mathrm{n}^{\circ} 1$ da Revista Londrina Index e em Esprit, Paris, em Setembro de 1972, numa edição extraordinária dedicada à sociologia do livro. Alfonso C. Comín utilizou, mas tarde, uma parte importante deste trabalho na análise que apresentou em Cuadernos para el Diálogo, Madrid, em Dezembro de 1972. Ainda neste ano, o Jornal Die Zeit publicou uma síntese do texto, no seu suplemento de 1 de Dezembro. Em Portugal, esse ensaio foi publicado pela primeira vez após a revolução de 25 de Abril de 1974, incluído no livro E Agora, José?, editado pela Moraes em 1977. Ao texto original acrescentei então um PostScriptum e algumas anotações.

Além dos livros que ia publicando, e apesar de não escrever muito, porque eu nunca me autocensurava nem pela minha cabeça passava essa hipótese, fiz outras coisas onde fui, igualmente, confrontando com o problema da Censura.

Concretamente, por exemplo, em fins dos anos cinquenta, princípios da década de sessenta, dirigi a revista Almanaque, que provocou bastante polémica, porque pretendia ridicularizar todos os provincianismos, independentemente da sua natureza. Da redação dessa revista faziam parte Luís Sttau Monteiro, Alexandre O`Neill, Vasco Pulido Valente, Augusto Abelaira e José Cutileiro. Agora diz-se que essa revista era muito boa, porque as pessoas não a leram. Diziam que era uma revista elitista, pretensiosa. Era fina de mais, cara de mais. Aquilo acabou porque não tinha público. Mas eu aí escrevia pouco, muito pouco mesmo. 
Uma década mais tarde, em 1968, dirigi, com assistência de Victor Silva Tavares, o "Suplemento Literário" do Diário de Lisboa. Mas também não estava lá o meu nome, nunca, porque eu sabia que se pusesse lá o meu nome teria muito mais dificuldades. Eles sabiam, a Censura sabia que era eu que dirigia o suplemento. Simplesmente, numa situação como aquela em que vivemos, em determinados momentos criavam-se entendimentos, diria entendimentos inconscientes. Eles sabiam que eu estava lá. Com certeza que sabiam, Digamos que pensavam: "Deixa-o estar, que a gente vê até onde ele vai." Isto é a ideia que eu tenho e que me leva a dizer, como referi inicialmente, que, com a Censura, vivemos num país alienado.

Meses depois, passei a dirigir igualmente o suplemento. "A Mosca", ainda do Diário de Lisboa, que se fartou de fazer ondas. Mas, repare-se, também meu nome aqui nunca aparecia. Talvez tenha aparecido uma ou duas vezes. Mas toda a gente sabia que era eu que dirigia "A Mosca". Praticamente, esse suplemento do Diário de Lisboa era feito por mim e pelo Sttau Monteiro. 


\section{Anexo 2}

Figura 1

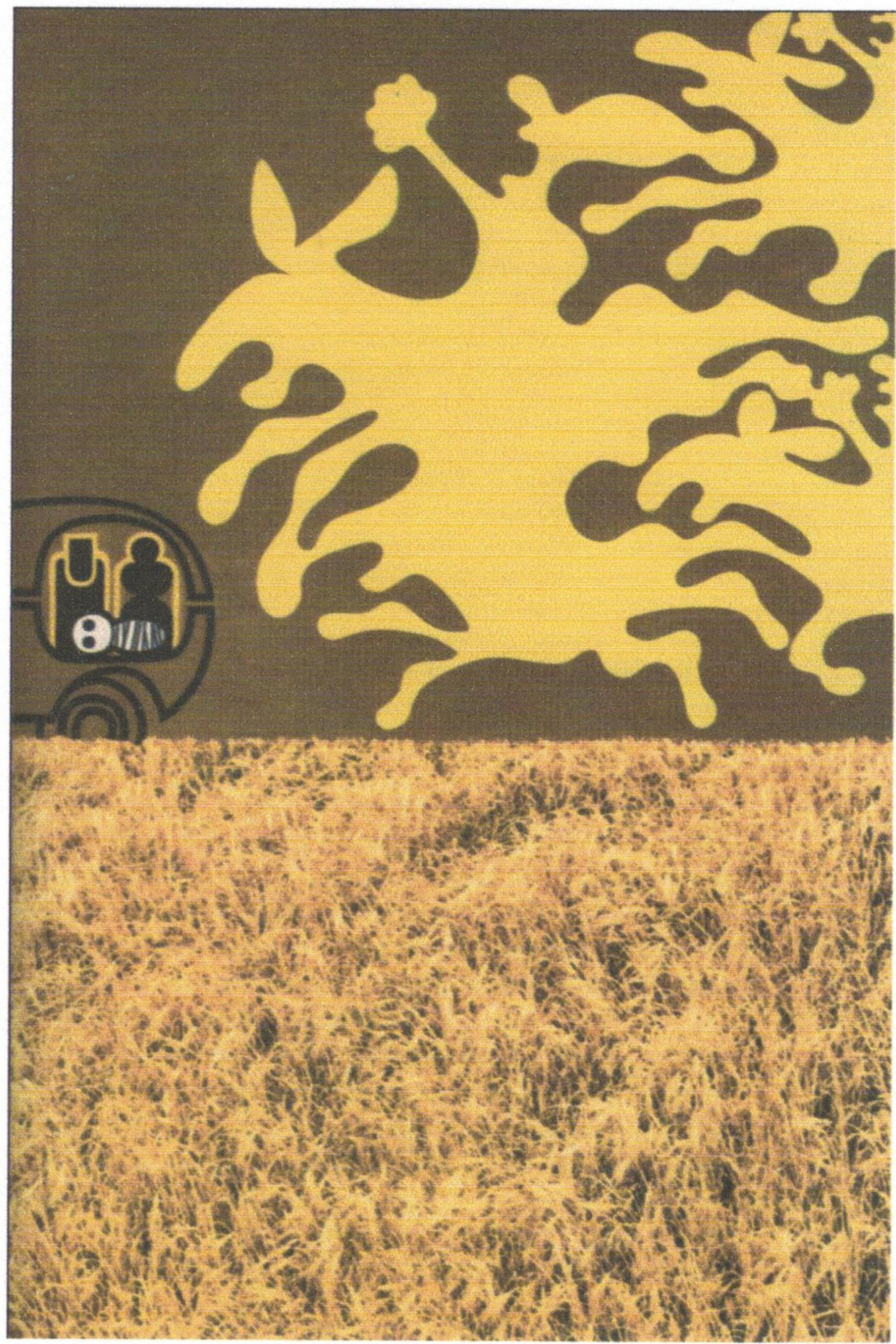

Fuga da família do Imperador-Dinossauro e perseguição dos jumentos. In: Dinossauro Excelentíssimo. Ilustrações de João Abel Manta. 5. ed. Lisboa: Bertrand, 1973, p. 20. 
Figura 2

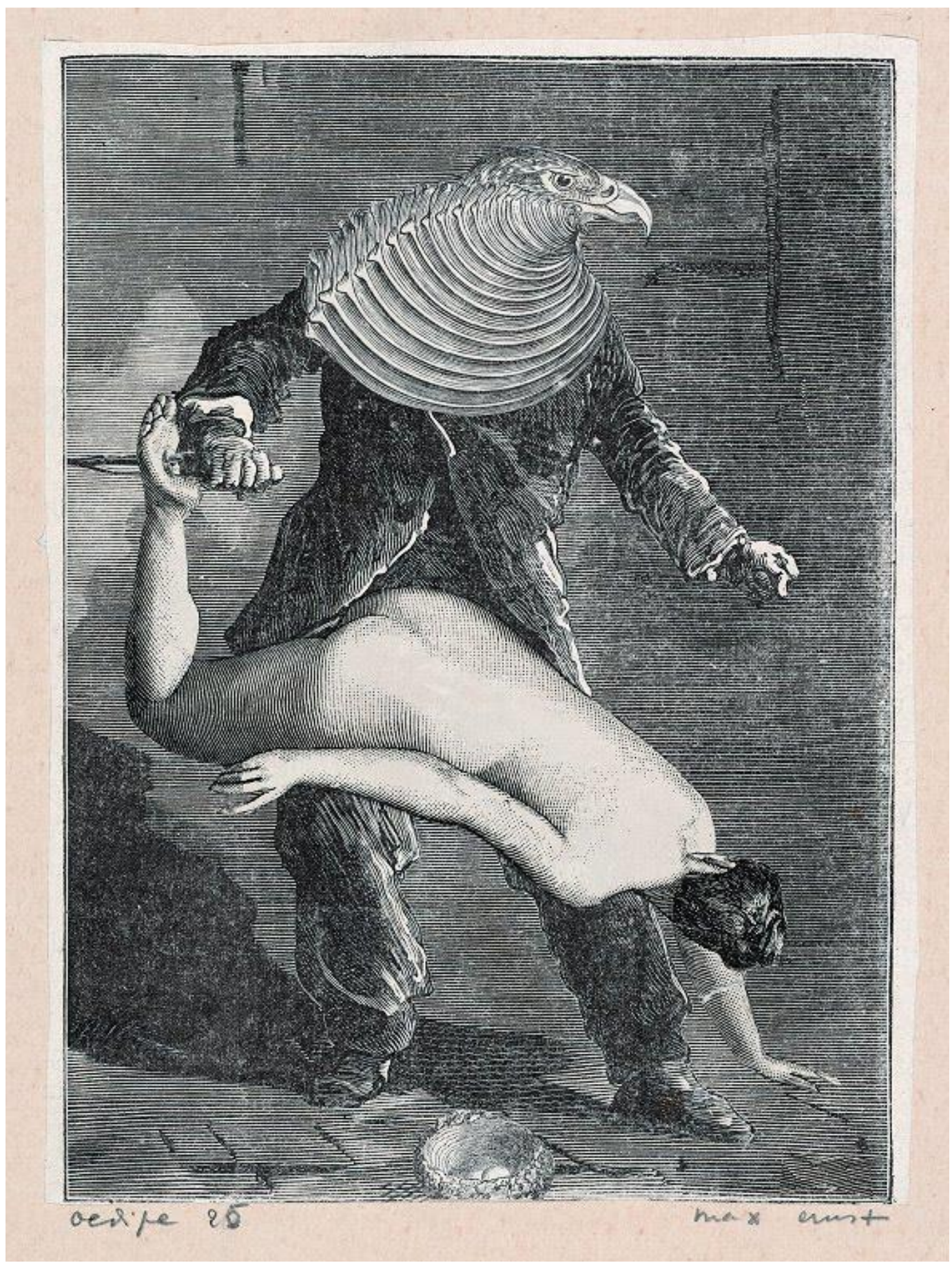

O homem-pássaro (Édipo 25). Ilustração de Max Ernst. Disponível em: <http://www.revistamuseu.com.br/naestrada/naestrada.asp?id=23636>. Acesso em: 22 out. 2010. 
Figura 3

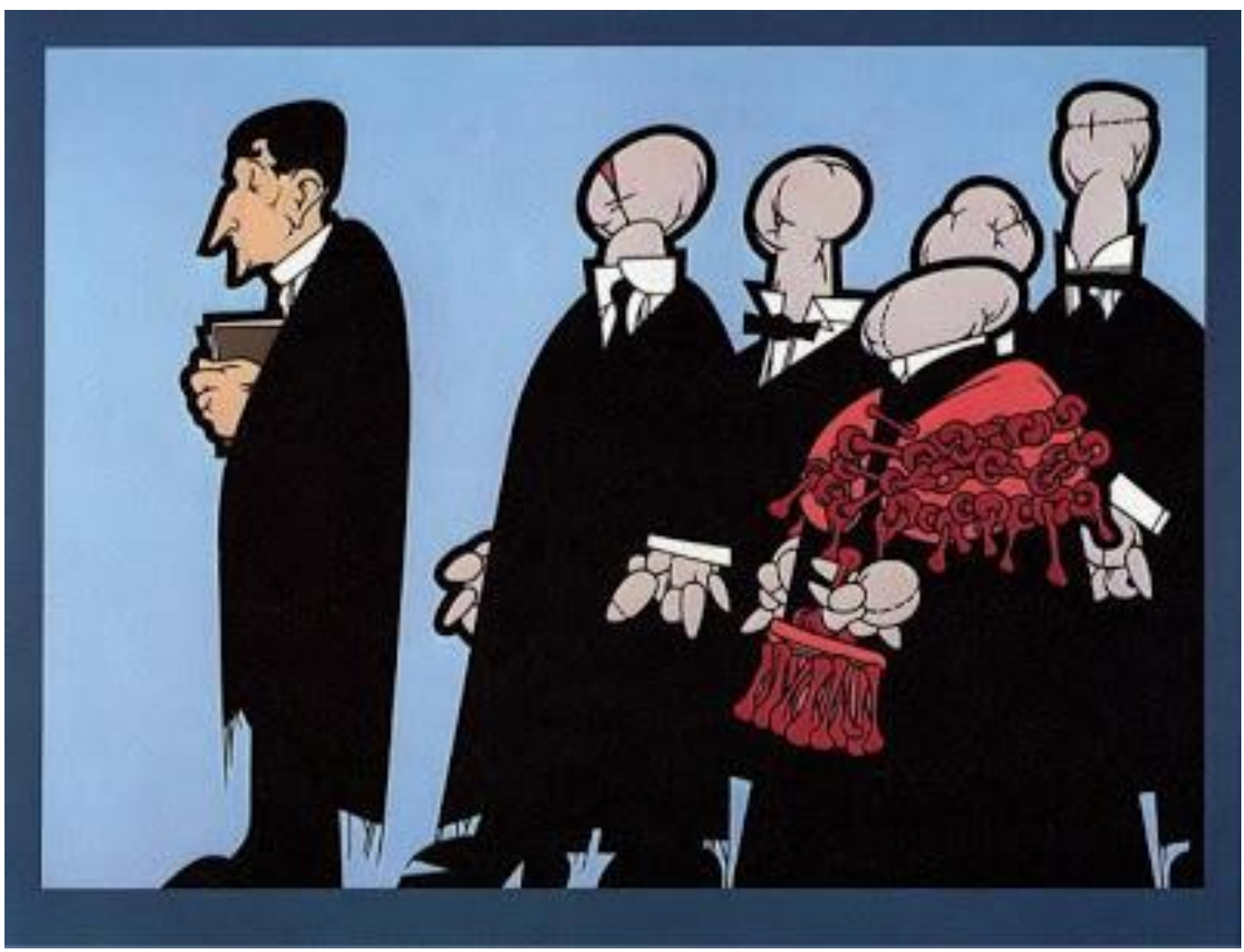

As Idades de Salazar 1. Produção do cartunista João Abel Manta. Nesta imagem, são representados Salazar e os Mestres responsáveis por seus estudos. Disponível em: $\quad<\mathrm{http}: / /$ arte-factoheregesperversoes.blogspot.com.br/2011/04/joao-abelmanta.html>. Acesso em: 22 mar. 2013. 
Figura 4

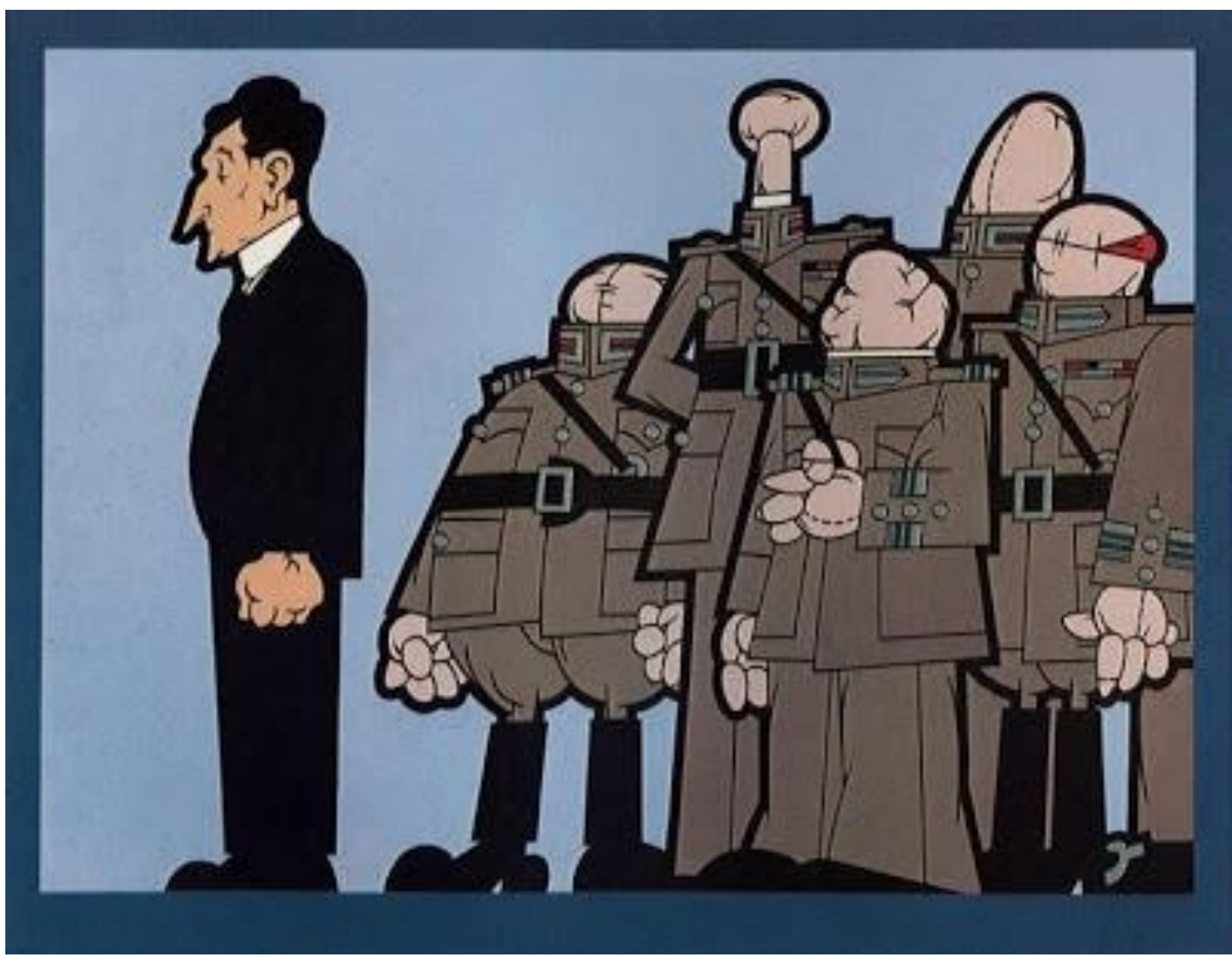

As Idades de Salazar 2. Produção do cartunista João Abel Mantas. Nesta imagem, são representados Salazar e os Militares que o trouxeram para o governo. Disponível em: <http://arte-factoheregesperversoes.blogspot.com.br/2011/04/ joao-abel-manta.html>. Acesso em: 22 mar. 2013. 
Figura 5

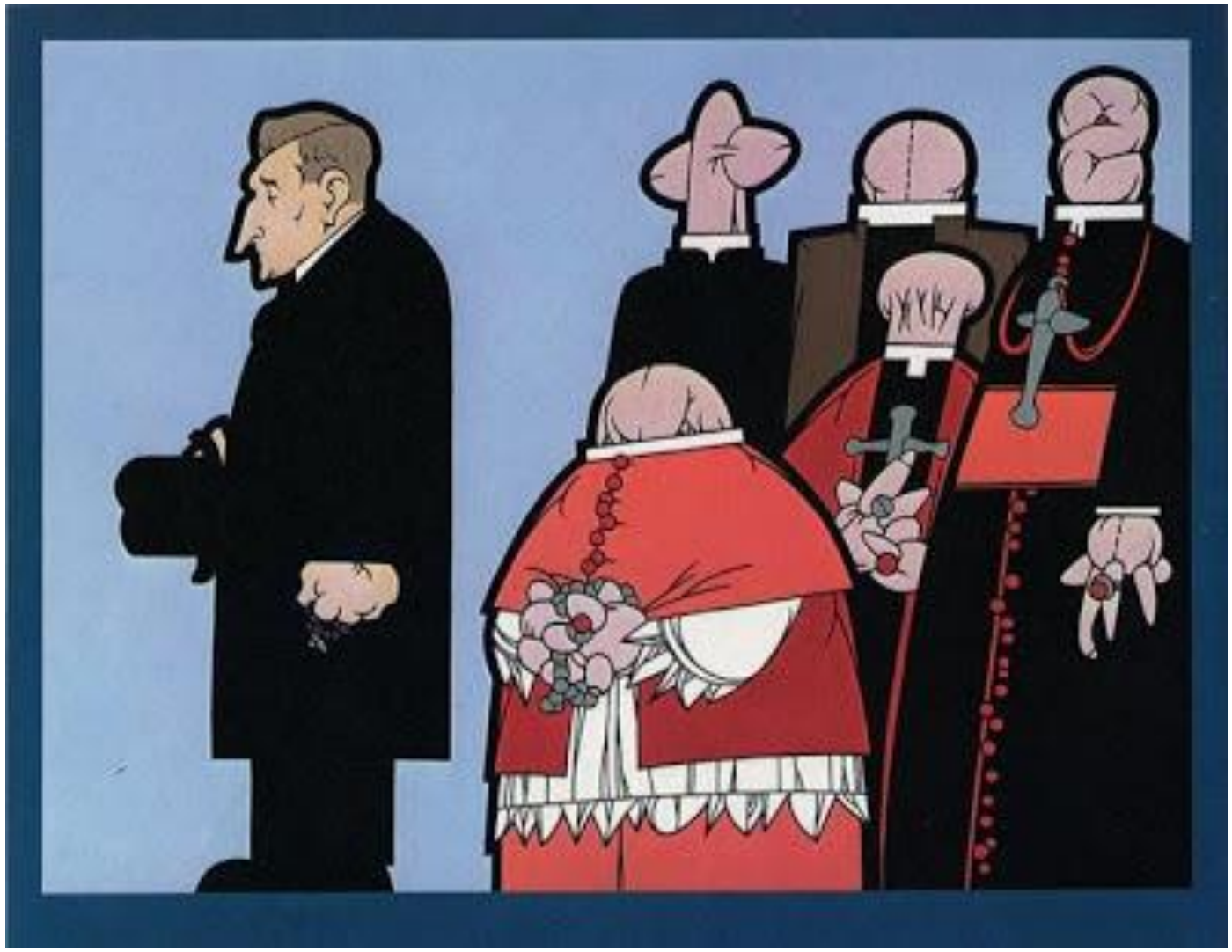

As Idades de Salazar 3. Produção do cartunista João Abel Mantas. Nesta imagem, são representados Salazar e os Padres que sempre apoiaram o seu governo. Disponível em: <http://arte-factoheregesperversoes.blogspot.com.br/2011/04/ joao-abel-manta.html>. Acesso em: 22 mar. 2013. 
Figura 6

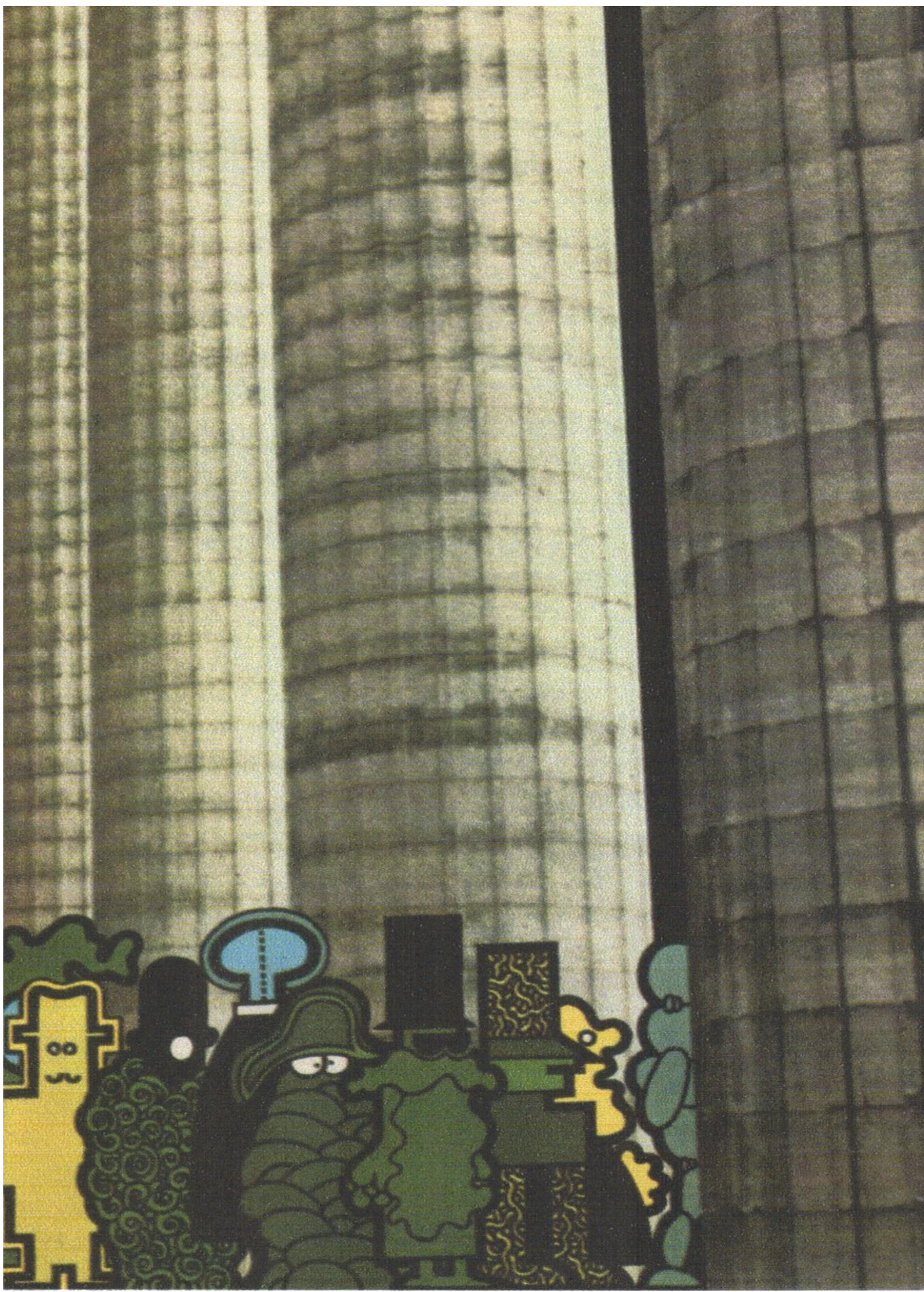

Personagens Dê-Erres, assessores e doutores, que se acercam do ImperadorDinossauro. Certos traços dos personagens destacam suas características. Embora, ao longo da narrativa, sejam comparados a animais - principalmente, a certos aspectos metonímicos -, eles não têm aspecto de animais. In: Dinossauro Excelentíssimo. Ilustrações de João Abel Manta. 5. ed. Lisboa: Bertrand, 1973, p. 92. 
Figura 7

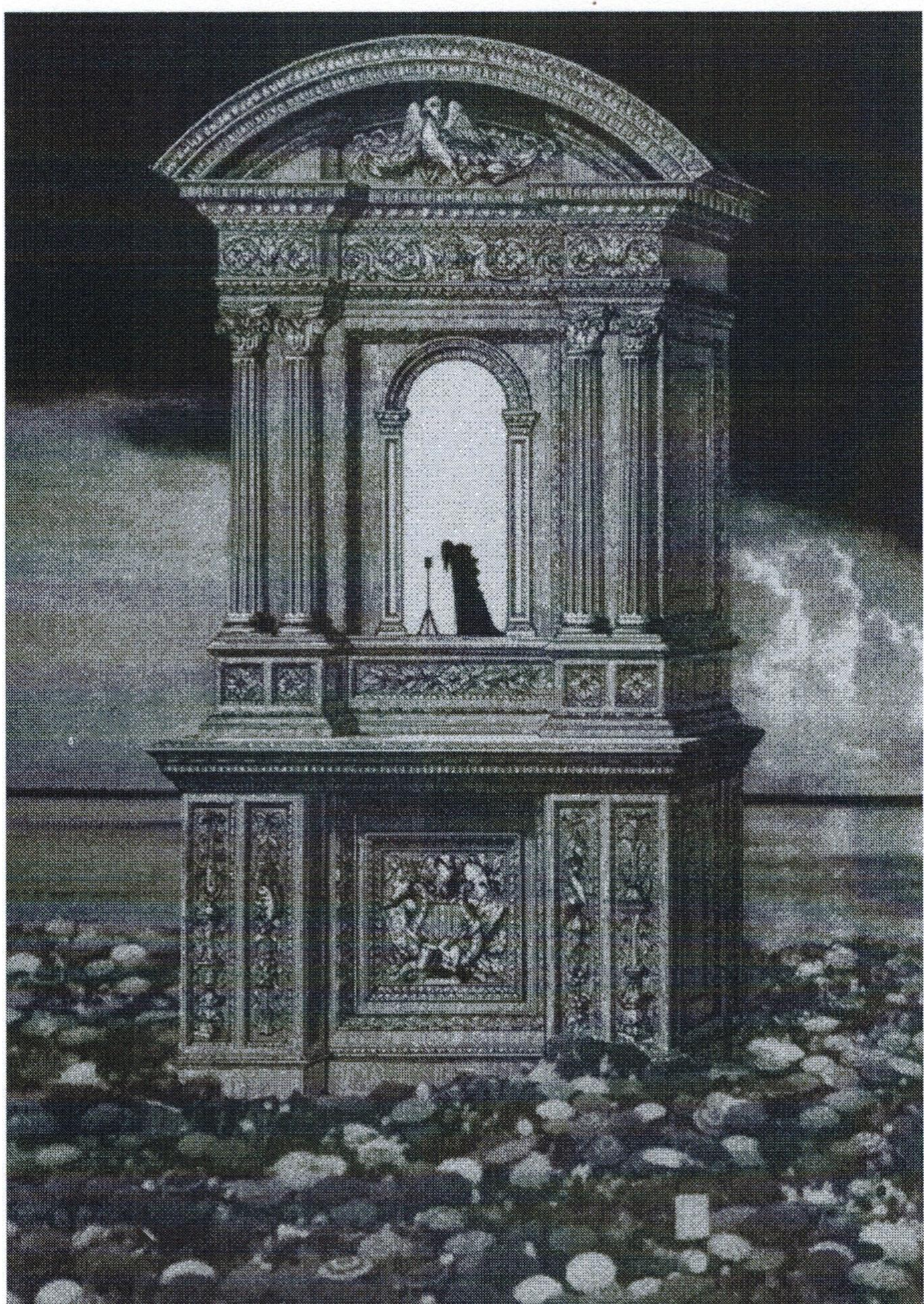

O Imperador-Dinossauro discursando para o povo, que não entendia a linguagem que ele utilizava para pronunciar suas ideias e já não se interessava em ouvir. Já demonstra a metamorfose física do Imperador. In: Dinossauro Excelentíssimo. Ilustrações de João Abel Manta. 5. ed. Lisboa: Bertrand, 1973, p. 60. 
Figura 8

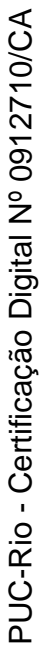

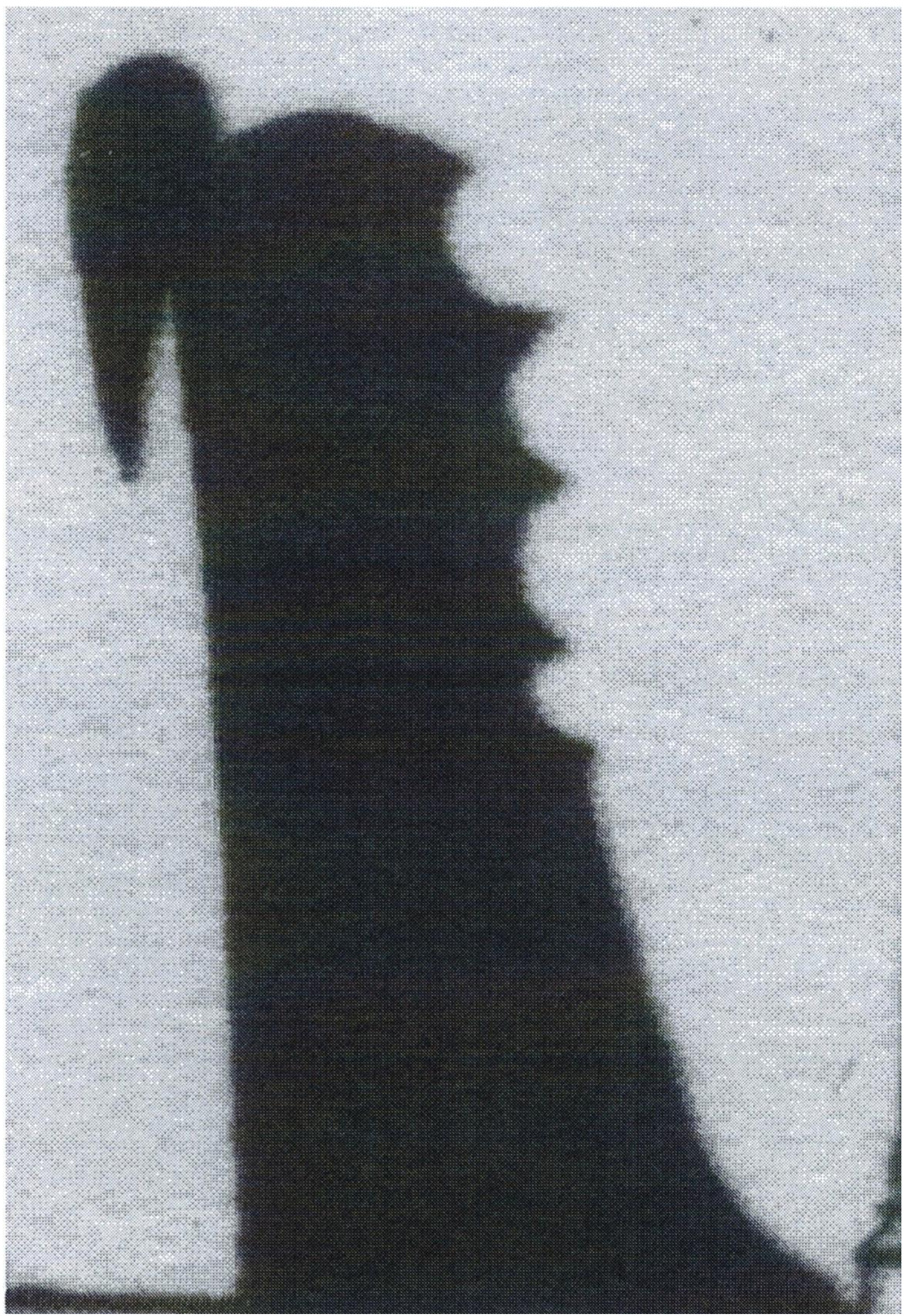

Detalhe da imagem do Imperador-Dinossauro após sofrer a metamorfose. In: Dinossauro Excelentíssimo. Ilustrações de João Abel Manta. 5. ed. Lisboa: Bertrand, 1973, p. 60. 
Figura 9

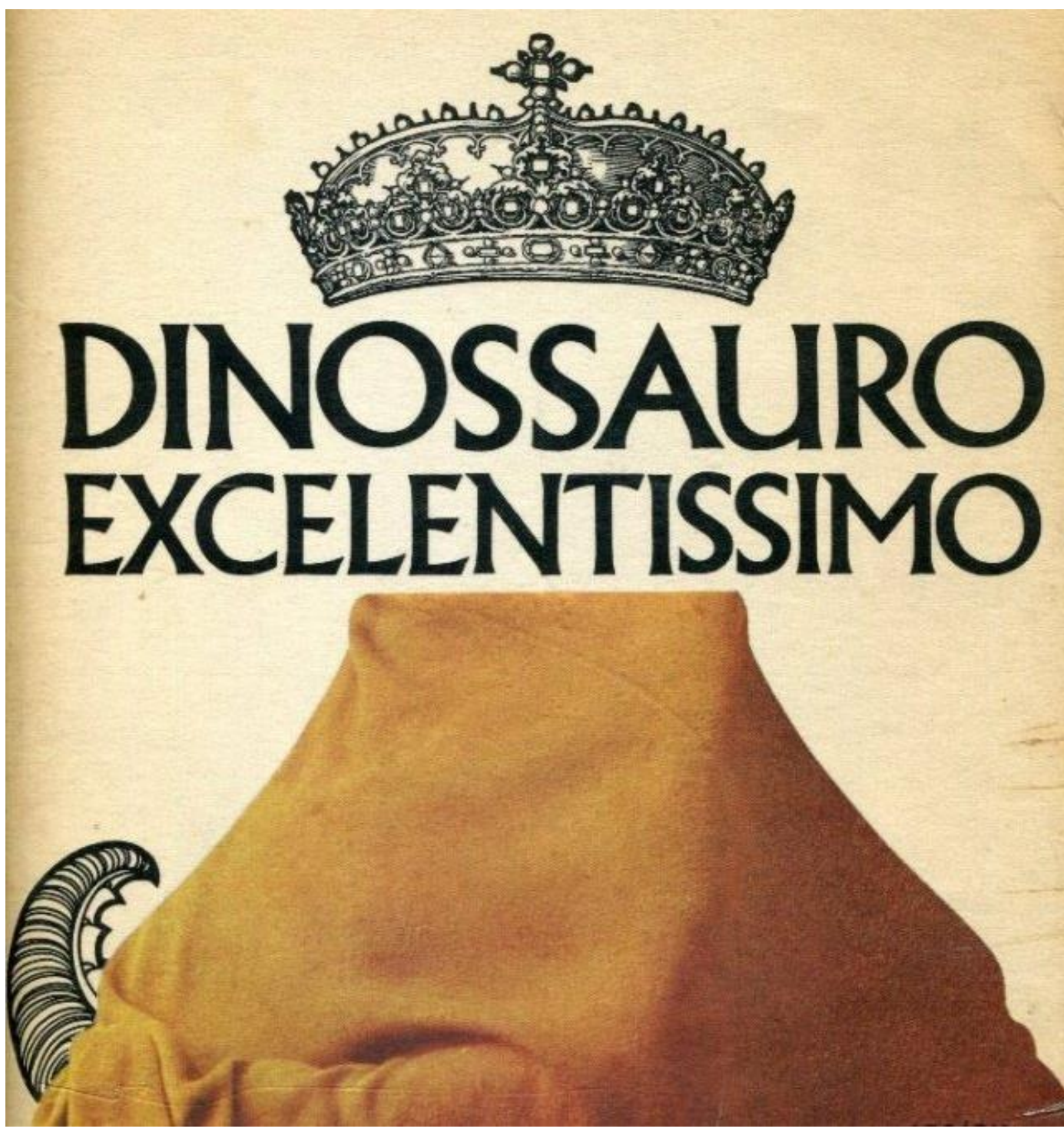

Capa da primeira edição de Dinossauro Excelentíssimo, de 1972. Ilustração de João Abel Manta. Se observarmos a construção dessa imagem, após reunir fragmentos metonimicamente retomados de outros textos, ela forma uma imagem alegórica do que poderíamos entender como concretização da ideia de poder, mas não é apenas isso, vai além pela própria leitura da imagem como um todo: encontramos a ideia de um poder muito antigo, arcaico, até mesmo "jurássico", e toda a carga semântica que dele emana: opressão, repressão censura, violência, etc. In: Dinossauro Excelentíssimo. Ilustrações de João Abel Manta. 5. ed. Lisboa: Bertrand, 1973. 
Figura 10

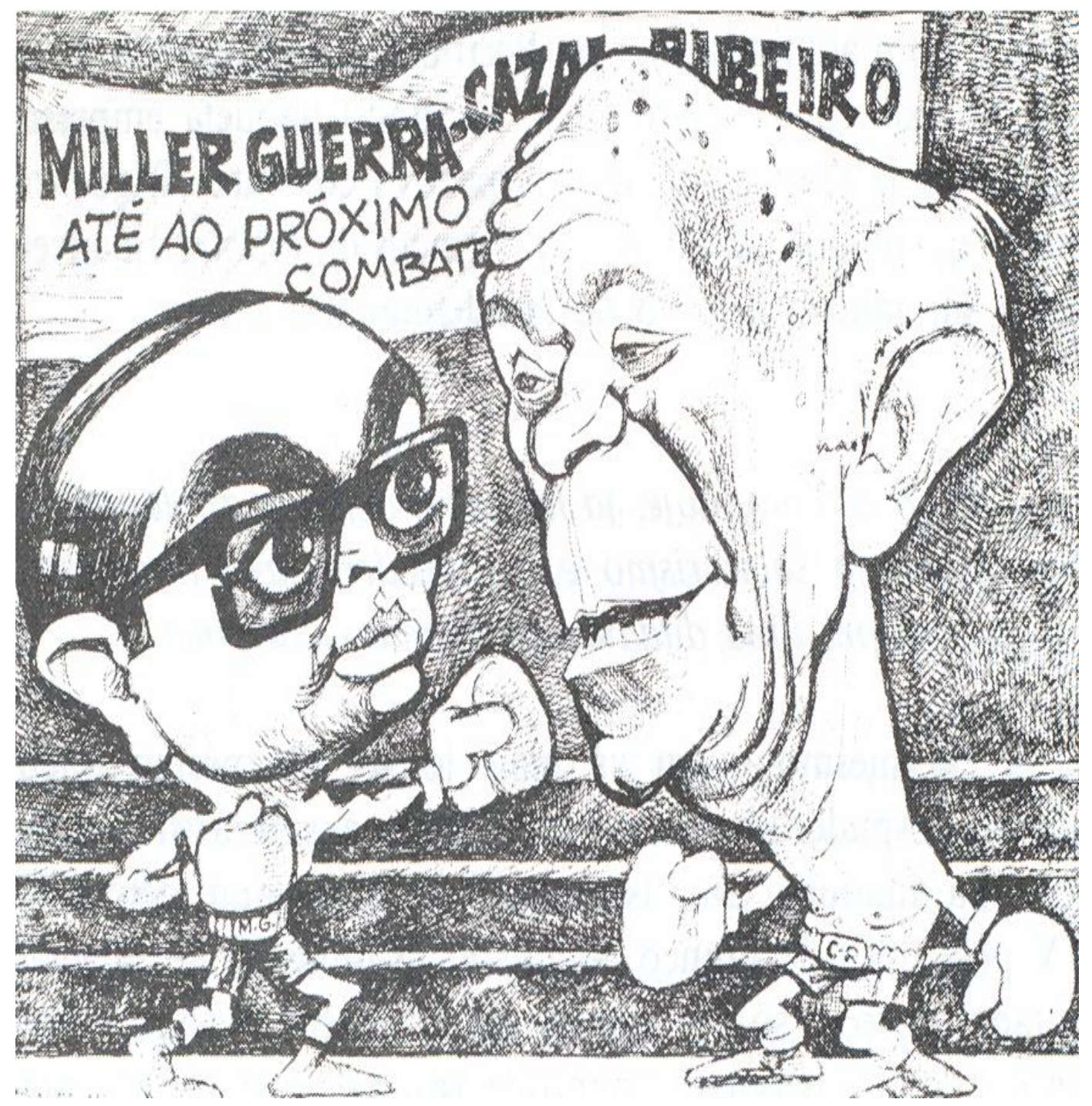

Confronto na Assembleia Nacional, Miller Guerra versus Cazal Ribeiro.

Caricatura de Baltazar. Vida Mundial, 7 dez. 1971. In: PORTELA, Arthur. Cardoso Pires por Cardoso Pires. Lisboa: Dom Quixote, 1991, p. 37. 
Figura 11

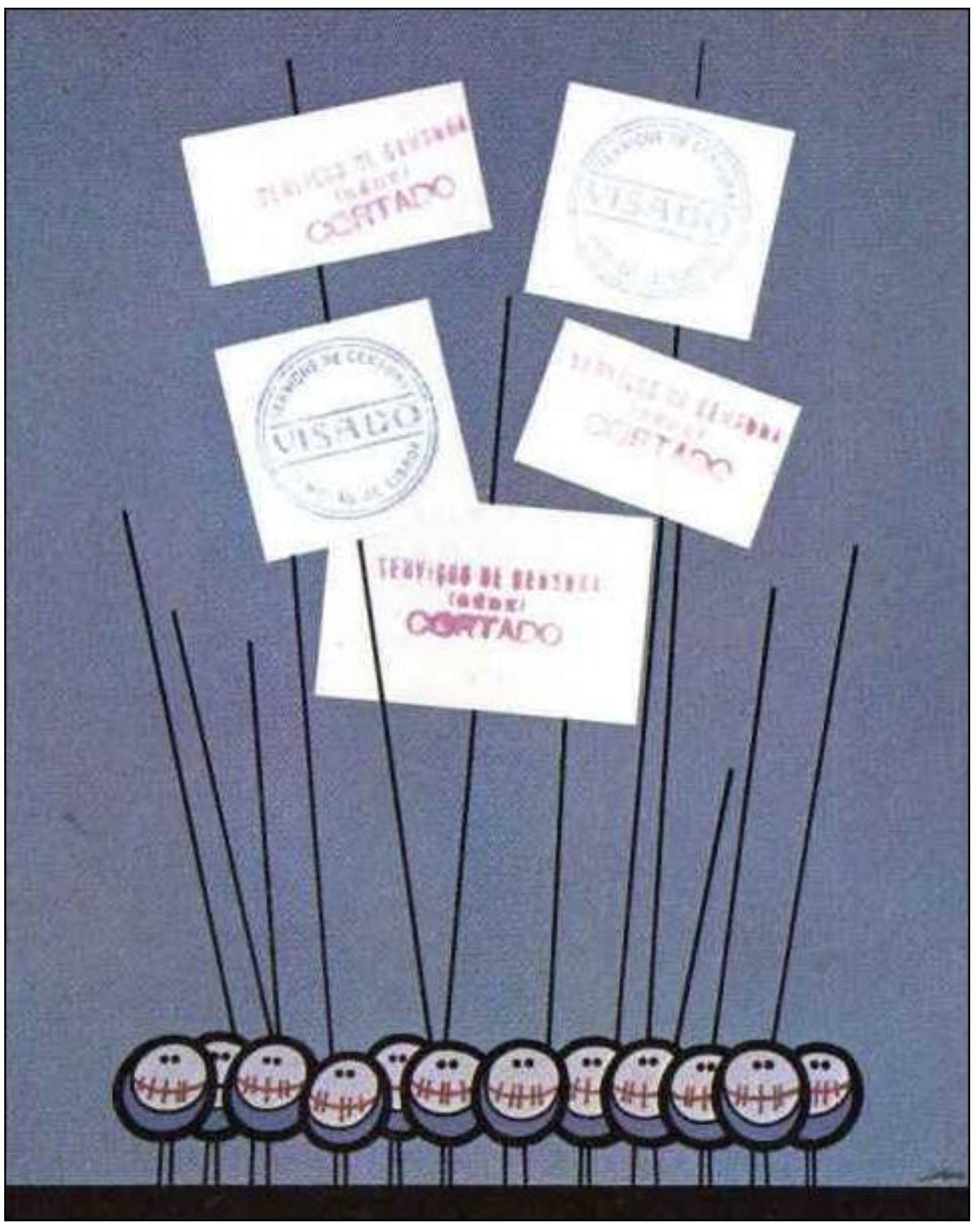

Representação da censura. A ideia contundente da censura é metaforicamente revelada através da ironia e da mordacidade. Ilustração de João Abel Manta. Disponível em: <http://arte-factoheregesperversoes.blogspot.com.br/2011/04/ joao-abel-manta.html>. Acesso em: 22 mar. 2013. 